\title{
O MOVIMENTO DA PROMOÇÃO DA SAÚDE NA DÉCADA DE 1990: UM ESTUDO DO SEU DESENVOLVIMENTO E DIFUSÃO NA SAÚDE PÚBLICA BRASILEIRA.
}

\section{DAIS GONÇALVES ROCHA}

Tese de Doutorado apresentada ao Departamento de Práticas de Serviço de Saúde Pública da Faculdade de Saúde Pública da Universidade de São Paulo.

Área de concentração: Serviços de Saúde Pública

Orientadora: Profa. Dra. Nelly M. F. Candeias
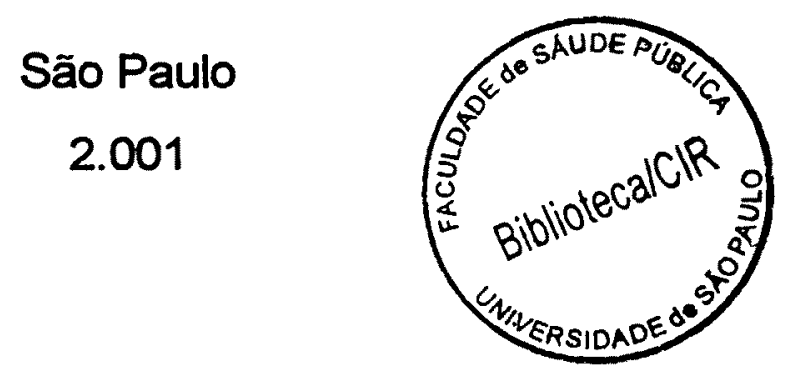
Autorizo, exclusivamente para fins acadêmicos e cientificos, a reprodução total ou parcial desta tese, por processos fotocopiadores.

Dais Gonçalves Rocha

Dezembro de 2001.

$4175612002 d x$ 


\section{AGRADECIMENTOS}

Grata sou a todas as pessoas que neste processo brindaram a minha vida com gestos e palavras de afeto, trazendo à lembrança a imagem de um dia de sol e céu azul do Planalto Central.

Profa Nelly M. F. Candeias, pelo que ensinou sobre ser orientadora, pelo apoio e estímulos necessários à conclusão desta etapa.

Vânia Cristina Marcelo, amiga e melhor interlocutora, gratidão por você ter dito: "Não tenha medo, Ihe ajudo na travessia..." Assim o fez.

Prof Anna Maria Chiesa, Isabel M.T. Bicudo Pereira, Márcia F. Westphal, Maria Cecília F. Pelicioni, Rosilda Mendes e Profo Luiz Eduardo W. Wanderley, integrantes da banca examinadora que contribuiram com valiosas sugestões.

Profa Maria da Penha C. Vasconcelos, desde o alinhavar das primeiras linhas do projeto desta pesquisa soube indicar referencias preciosas e, com uma escuta e fala generosa, me auxiliou diante das muitas encruzilhadas e paralisias.

Aos entrevistados, pela amabilidade e paciência com que me acolheram e pelo muito que ensinaram sobre o fazer saúde pública no Brasil.

Às equipes da Secretaria Municipal de Saúde de Goiânia e da Faculdade de Odontologia de Anápolis, que me apoiaram durante o periodo de licenciamento e de escrita da tese. 
Toda a equipe da Biblioteca da Faculdade de Saúde Pública, especialmente, à Maria Lúcia de Faria Ferraz que, desde o Mestrado, com carinho e competência, auxilia na busca das informaçōes e na revisão das referências.

Amigos da Secretaria de Pós-Graduação e Serviço de Aprimoramento da FSP/USP: Rê, Márcia, Cidinha, Marilene e Ângela, que fazem com que os "rituais de passagem" da Universidade sejam mais suportáveis.

Ao CNPq, pela bolsa de estudos.

Meus pais, Ena May e João Paulo, pelo abrigo afetuoso do seus colos e das suas orações. 


\section{RESUMO}

Rocha, DG. O movimento da promoção da saúde na década de 1990: um estudo do seu desenvolvimento e difusão na saúde pública brasileira. São Paulo; 2.001. [Tese de Doutorado - Faculdade de Saúde Pública da USP]

O tema promoção da saúde tem sido proposto para discussão em diversos fóruns da saúde pública brasileira. Buscou-se compreender como foi constituido e implementado o movimento da promoção da saúde no Brasil, na década de 1990, a partir da opinião de profissionais e dos documentos mais relevantes da área. Desenvolveu-se uma pesquisa, de tipo qualitativa, com os dados levantados mediante entrevistas semidiretivas e análise documental. Foram criadas categorias de análise, a partir das quais são apresentados e discutidos os resultados. Constatou-se que a difusão da promoção da saúde, no Brasil, ocorreu após a segunda metade da década de 1990 e que a Organização PanAmericana de Saúde (OPAS) desempenhou um papel fundamental nesse processo. Identificou-se as principais estratégias de difusão, conceitos associados à promoção da saúde, elementos que favoreceram a entrada deste movimento no Brasil e os principais setores responsáveis pela implementação dessa prática Evidenciou-se que os documentos que constituem a base conceitual desse movimento são, predominantemente, Cartas e Declarações das Conferências Internacionais. Trata-se da re-emergência e não do surgimento do termo, na prática da saúde pública ocidental. Ao caracterizar-se o movimento da promoção da saúde, constatou-se que este é orientado não apenas por um conceito de saúde como resultado das condições concretas de vida, mas, também, como recurso objetivo e subjetivo de individuos e comunidades

Descritores: Promoção da Saúde. Saúde. Educação em Saúde. Estratégias de Difusão. 


\section{SUMMARY}

Rocha, DG. O movimento da promoção da saúde na década de 1990: um estudo do seu desenvolvimento e difusão na saúde pública brasileira. [The health promotion movement in the 1990's: a study of its development and diffusion in the Brazilian public health.] São Paulo (BR); 2.001. [Tese de Doutorado - Faculdade de Saúde Pública da USP].

Health promotion has been proposed as a theme for discussion in several spaces of the Brazilian public health. The aim of this study was to understand how it was implemented and constituted in the Brazilian reality in the 1990's. This was done considering the point of view of professionals and the most relevant documents of the area. This research used a qualitative method and the data was collected through semi-directive interviews and documental analysis. After that, analysis categories were created and the results were presented and discussed. It was observed that the diffusion of health promotion in Brazil happened in the late 1990's and that the Pan-American Health Organization has a very important role in this process. This study identified the main diffusion strategies as well as the concepts associated to health promotion, the elements that helped the entering of this movement in Brazil and also the main sectors that are responsible for the implementation of this practice. It became evident that the documents that constitute the conceptual basis of this movement are, predominantly, the Declarations and Statements of the International Conferences. The term health promotion is re-appearing in the occidental health practice. As the movement of health promotion was characterized, it was noticed that it is guided not just by the concept of health as a result of the concrete conditions of living, but also as an objective and subjective source of individuals and communities.

Descriptors: Health Promotion. Health. Health Education. Diffusion Strategies. 
"Se há algo que precisamos, os brasileiros, realizar mais amiudamente, sem ligeirezas, com rigor, é anotar o tempo vivido, o tempo fazendo-se e em que nos fazemos. Me parece fundamental ir mais além dos limites de nossa memória oral e intensificar a necessária prática de registrar o que ocorre."

(PAULO FREIRE, 1984) 


\section{SUMÁRIO}

1. APRESENTAÇÃO

2. CONTEMPORANEIDADE E SAÚDE

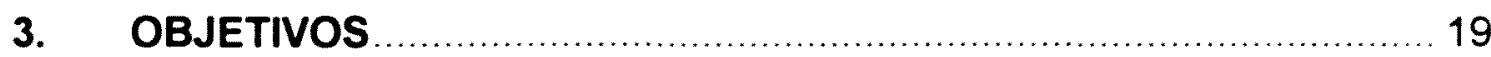

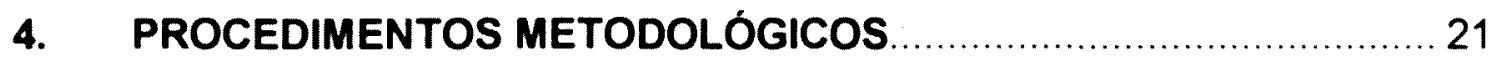

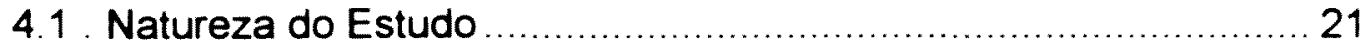

4.2. Usos dos Instrumentos de Pesquisa ......................................... 31

4.3. O Processo de Transcrição das Entrevistas e a Definição das

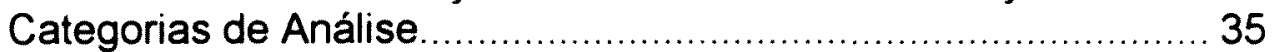

5. OS PARTICIPANTES DA PESQUISA

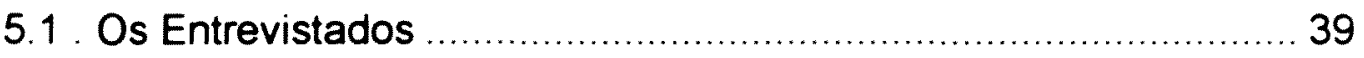

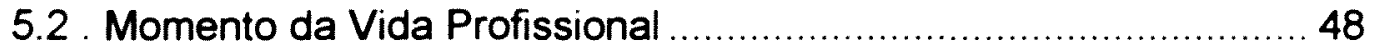

6. BASES CONCEITUAIS DO MOVIMENTO DA PROMOÇÃO

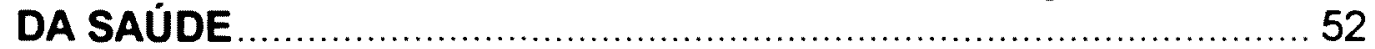

6.1. Conceitos Associados à Promoção da Saúde ............................ 52

6.2. Documentos das Conferèncias .................................................. 73

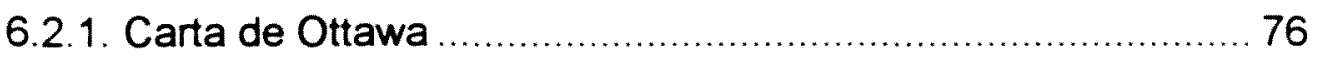

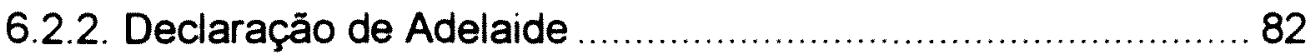

6.2.3. Declaração de Sundsvall.................................................... 90

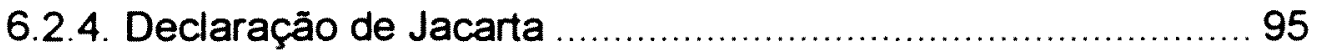

6.2.5. Declaração Ministerial do México .......................................... 101

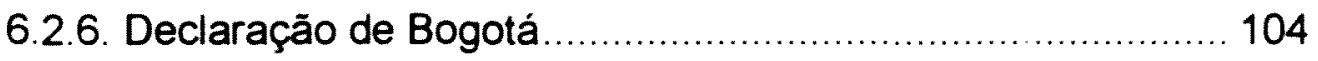

6.2.7. Carta de Fortaleza ......................................................... 111 
7. ELEMENTOS QUE FAVORECERAM A ENTRADA DA

8. ESTRATÉGIAS DE DIFUSÃO DA PROMOÇÃO DA SAÚDE ............ 146

8.1. Municípios ou Cidades Saudáveis .................................... 150

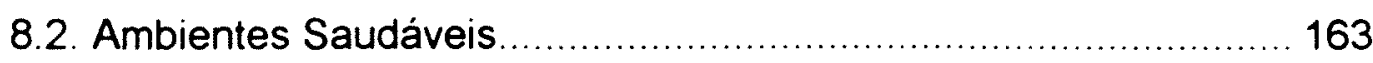

8.2.1.Escolas Promotoras de Saúde .................................... 166

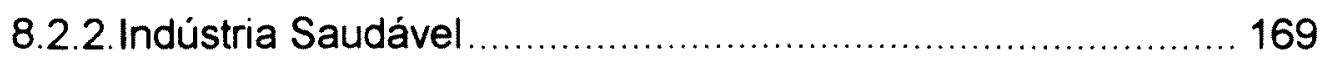

8.3. Incentivo para Publicações .............................................. 175

8.4. Organização de Eventos e Fóruns de Discussões................... 178

8.5. Formação de Recursos Humanos nas Escolas ou Núcleos de Saúde Pública ................................................. 188

9. CARACTERIZAÇÃO DO MOVIMENTO DE PROMOÇÃO DA SAÚDE 190

10. SETORES RESPONSÁVEIS PELA IMPLEMENTAÇÃO DAS

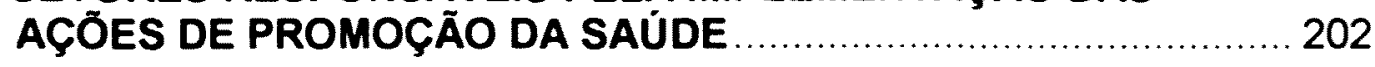

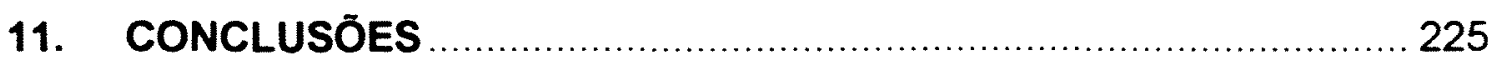

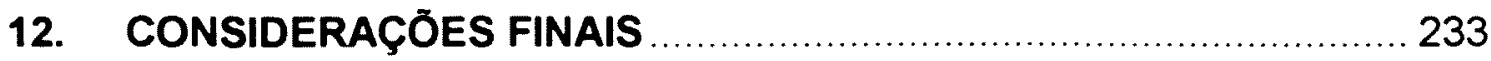

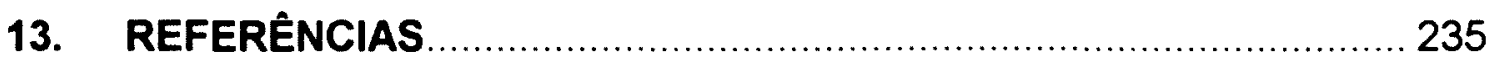

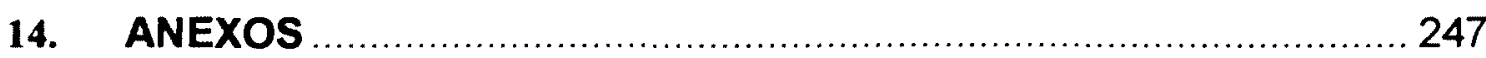

Anexo 1 - Roteiro de Entrevista

Anexo 2 - Termo de Consentimento

Anexo 3 - Lista dos Informantes 


\section{APRESENTAÇÃO}

O interesse pelo tema promoção da saúde foi desenvolvido após a autora ter se dedicado, durante o curso de Mestrado, à compreensão dos objetivos que têm sido atribuidos à Educação em Saúde no Brasil por parte dos profissionais da área da saúde e, mais especificamente, pela categoria odontológica nos seus Programas. Esse termo surgiu na literatura internacional, principalmente a partir do final da década de 1980, vinculado a propostas de educação em saúde e, em alguns casos, até mesmo nomeando estas práticas educativas. A partir dessa época, pôde-se identificar, nas falas e publicaçōes dos profissionais da área, uma certa tendência à substituição do termo "educação em saúde" pelo termo "promoção da saúde", este utilizado, de forma indiscriminada, nos mais diferentes contextos.

O tema promoção da saúde tem sido proposto no campo da saúde pública brasileira em diversos fóruns - congressos, seminários, oficinas, workshops, cursos de pós-graduação - considerado como um "novo" paradigma de saúde, capaz de superar a visão biomédica que, até a atualidade, se limitou a pensar a saúde apenas como ausência de doença. As óbvias limitações da visão biomédica nas práticas de saúde têm sido amplamente discutidas por vários estudiosos (DEJOURS 1986; MENDES 1996; KAWACHI 1997; WESTPHAL 1997b; ZIGLIO 2000). O que aqui se apresenta, como problema para estudo, diz respeito às expectativas que os profissionais da saúde têm quanto à sua utilização, que advogam a promoção da saúde no Brasil. Essa prática tem sido apresentada como referencial na busca de "um

\footnotetext{
'BUNTON e MACDONALD (1992) definem por visão ou modelo biomédico: "a compreensấo ou enfoque sobre a causa e tratamento da saúde e da doença em termos da causa e efeito biológicos. Esta abordagem năo se refere às condiçbes sociais, psicologicos ou económicos que podem ter influencia sobre a saúde do individuo."
} 
paradigma mais abrangente e explicito que supere a concepção clínicoassistencial para a questão da saúde/doença na sociedade." (BUSS e IGNARRA 1996).

Essa questão pode ser vista como uma das perguntas norteadoras do presente estudo: como tem se constituido e difundido o movimento da promoção da saúde, na saúde pública, no Brasil, na década de 1990 ?

Cumpre iniciar este estudo esclarecendo que por "movimento" se entende o processo implementado por pessoas e grupos atuando na mesma direção ou rumo. Trata-se, nesse caso, da construção e do desenvolvimento de um projeto de intervenção na saúde pública brasileira, de interesse para um grupo determinado de profissionais. A idéia de "movimento" visa apreender o momento da proliferação do discurso da promoção da saúde e o percurso percorrido por ele à medida que se afasta do espaço acadêmico para atingir a prática.

A visão que norteou este estudo foi a de que o movimento de promoção da saúde diz respeito a um conjunto de experiências humanas. Interessa saber como os participantes deste processo significam e constroem arranjos diferentes ou particulares, em função das recomendações e experiências internacionais divulgadas, e como pensam concretizar a prática da promoção da saúde no Brasil.

A palavra movimento contém a idéia de dinamicidade, de algo em processo: de vir a ser ou pretender um vir a ser. Sendo esta a natureza do objeto deste estudo, para apreender os seus contornos ou estabelecer os nexos necessários para a análise aqui pretendida, recorreu-se ao arsenal metodológico de algumas disciplinas das ciências sociais, principalmente da história, antropologia e sociologia. 
O primeiro aspecto a ser considerado no conceito de promoção da saúde diz respeito à sua historicidade: como este tem sido construído socialmente? É importante observar como o conceito $e$ as idéias a ele associado foram se alterando ao longo dos tempos, até assumir, na atualidade, a conotação de "nova saúde pública".

As Conferências Internacionais de Promoção da Saúde e seus documentos oficiais têm sido referendados como base conceitual do movimento de promoção da saúde. Por isso, esses documentos serão aqui apresentados com a intenção de contextualizá-los à luz de uma leitura crítica, designando-se por leitura crítica aquela que busca o nexo existente entre os discursos ou relatos e o contexto em que foram produzidos. Constitui, portanto, um exercicio de aprendizagem constante da busca dos nexos entre 0 ideário (idéias, enunciados, declarações) de uma proposta de saúde e os fundamentos que a acompanham.

O periodo de tempo selecionado, para compreender o movimento da promoção da saúde no Brasil, abrange a década de 1990. As primeiras publicações e eventos com esta temática datam de 1993. Ao se falar em promoção da saúde, os autores remetem o leitor ao conceito discutido na Carta de Ottawa. Para iniciar a produção nesta data, pode-se perguntar: quando os estudiosos e divulgadores de promoção da saúde entraram em contato com ela?

A participação em vários eventos com esta temática, leva à observação que esta década configurou um determinado cenário para a emergência deste movimento que traz, enquanto intenção: difundir a promoção da saúde no Brasil. Pode-se ressaltar que esta década se caracterizou, entre outras, por ser uma época de dupla virada: de século e de milènio.

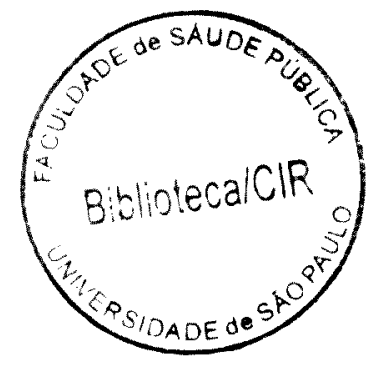


Às vésperas da X Conferência Nacional de Saúde, em 1996, o Ministério da Saúde, através da Fundação Oswaldo Cruz e da Assessoria de Comunicação, Programa de Informação, Educação e Comunicação (IEC), distribuiu 5.000 exemplares das declarações das quatro Conferências Internacionais de Promoção da Saúde já realizadas até aquela data, de Ottawa a Sundsvall, e da Conferência de Bogotá, esta especifica para a América Latina. Os organizadores da coletânea afirmam: "é necessário avançar na democratização das informações e propiciar a um número cada vez maior de pessoas o contato com os documentos que expressam os momentos-chave da evolução desse conceito" (BUSS e IGNARRA 1996). No capitulo de introdução da referida coletânea, a promoção da saúde é apresentada como "um novo paradigma mundial para a saúde."

O Ministério da Saúde lançou no início do ano de 2.001, uma nova edição da coletânea das Cartas, desta vez em versão bilingüe: português e inglès, incluindo as Declarações de Jacarta 1997 e México 2000, além do documento de Alma-Ata 1976 e da Rede dos Megapaises. (MINISTÉRIO DA SAÚDE 2001)

\section{Para CARVALHO e LIMA (1992):}

“(...) a institucionalização de qualquer campo de estudos não se faz sem o balanço critico permanente das tendéncias presentes ali, quer do ponto de vista do seu embasamento teórico e do alcance das investigações propostas, quer do ponto de vista do produto final, isto é, daquilo que resulta do esforço coordenado de tantas pessoas, às vezes por tantos anos."

Nesses termos, este trabalho visa realizar um "balanço crítico" do movimento de promoção da saúde no Brasil, mediante a opinião dos profissionais que atuam e difundem o conceito na área da Saúde Pública. Espera-se contribuir para o aprofundamento do estudo da promoção da saúde 
em nosso meio, identificando açōes, estratégias e espaços de atuação dos seus difusores. 


\section{CONTEMPORANEIDADE E SAÚDE}

"Discursos sobre saúde entram e saem de moda, mas não arbitrariamente. Ao contrário, eles emergem e se espalham ganhando aceitação porque eles são mais ou menos congruentes com o prevalecente no contexto social, politico e econômico, dentro dos quais eles são produzidos, mantidos e reproduzidos. Ainda, porque eles estão sempre aderidos a outros interesses e agendas - profissional, econômica, politica, cultural, ideológica - as formas que conceituamos, falamos e escrevemos sobre saúde nunca são simplesmente sobre saúde; elas também funcionam como depositários e espelhos de nossas idéias e crenças sobre a natureza humana e a natureza da realidade, bem como sobre o tipo de sociedade que nós podemos imaginar sendo criada e a melhor forma de atingi-la."

(ROBERTSON 1998)

Em meados da década de 90, fazendo parte do corpo de alunos do curso de Mestrado e, posteriormente de Doutorado, observou-se e pôde-se participar de um crescente número de debates e cursos que advogavam, no interior da Faculdade de Saúde Pública, da Universidade de São Paulo, que a promoção da saúde representaria a "nova" saúde pública. Um dos principais argumentos era a de que a adoção deste referencial possibilitaria ir além do que já havia sido feito historicamente na área da saúde. 
O termo promoção da saúde já fazia parte do acervo das terminologias dos profissionais da saúde, fato que será discutido em capítulos subsequentes. Foi reintroduzido, na década de 90 , sob duas perspectivas: às vezes nomeando ou associado às práticas consideradas "inovadoras", na medida que estas impulsionavam o setor saúde a enfrentar os determinantes e não somente as consequências dos problemas da área. Ousando mais, combater as desigualdades existentes na sociedade. Outras vezes, era associado a práticas educativas dirigidas à mudança de comportamentos das pessoas, focalizando seus estilos de vida ou combatendo hábitos nocivos à saúde.

As possibilidades de compreensão das práticas associadas à promoção da saúde acima apresentadas são identificadas, também, na literatura internacional. ALLISON e ROOTMAN (1996, p. 334), a partir de um estudo de GREEN e RAEBURN (1988), ao analisarem o desenvolvimento conceitual da promoção da saúde a agrupam, também, em dois grandes blocos:

"Uma abordagem, a mais prevalente nos Estados Unidos, nas duas últimas décadas, concebe a promoção da saúde como uma tentativa de reduzir os riscos do estilo de vida, através de programas dirigidos a indivíduos ou grupos populacionais específicos. Exemplos de pesquisa deste tipo de promoção da saúde incluem a avaliação em larga-escala de intervenções comunitárias que objetivam modificar fatores de risco, tais como tabagismo, atividade física e dieta. O outro tipo de promoção da saúde que GREEN e RAEBURN (1988) descrevem, exemplificadas por abordagens adotadas no Canadá e vários países Europeus, enfatiza a influência da estrutura social na saúde. Esta abordagem, ao menos filosoficamente, direciona intervençōes em alvos do tipo redução de iniquidades nas oportunidades de se ter uma boa saúde." 
No Brasil, o termo promoção da saúde, no período investigado, passou a ser anunciado enquanto novidade e foi sendo incorporado no discurso de técnicos e nos documentos de diversos órgãos governamentais da área da saúde. A título de exemplo, pode-se citar, a Proposta de um Plano de Ações de Promoção da Saúde (GONÇALVES et al. 1997), apresentada, em dezembro de 1997, pela Fundação Nacional de Saúde, um dos órgãos do Ministério da Saúde. De acordo com os autores:

"Acredita-se que a adoção da ótica da promoção da saúde, na concepção dos sistemas de vigilância aqui proposta, pode contribuir sobremaneira para a reestruturação do conhecimento dos determinantes da saúde e da indicação de caminhos de ação que permitam envolver outros setores governamentais e a sociedade na solução dos problemas."

É importante analisar o cenário que estava colocado para a saúde brasileira, na década de 1990, que impulsionava ou despertava para a necessidade de ir além.

Segundo VIANNA et al (2001):

"As aspirações individuais e coletivas de viver mais, com a melhor qualidade de vida possivel e, ao mesmo tempo, desfrutar do sentimento de segurança quanto a possibilidade de acesso aos serviços de saúde sempre que necessário, estão entre os valores mais cultuados na sociedade brasileira. $E$ o que sugerem as pesquisas de opinião ao apontar a saúde como o segundo problema mais importante para a população somente ultrapassado, antes do Plano Real, pela inflação, e depois dele, pelo desemprego."

Neste mesmo trabalho, VIANNA et al citam a Pesquisa Nacional por Amostra de Domicilios (PNAD) realizada em 1998 em que 79,1 \% dos 
brasileiros avaliam sua saúde como boa/muito boa. Quando se consideram as diferenças regionais a variação deste dado é de 74,4 na região Norte a 81,4 \% na região Sudeste, significando que "entre 20 e $25 \%$ da população brasileira está insatisfeita com seu estado de saúde, ou seja, entre 33 e 42 milhões de pessoas, aproximadamente, apresentam - segundo a própria percepção algum problema de saúde." Cerca de $30 \%$ da população declara ser portadora de uma ou mais doenças crônicas no pais.

O Brasil tem acompanhado a tendência geral da América Latina onde vêm acontecendo transições demográfica, ambiental e epidemiológica decorrentes do crescente envelhecimento populacional, acentuada urbanização, degradação ambiental e controle, mesmo que parcial, de doenças transmissiveis assim como crescimento dos fatores de risco para as doenças crônicas. No diagnóstico da Situação da Saúde Urbana na América Latina (Comissão Européia: Saúde e Assentamentos Humanos na América Latina, 1999) há a afirmação de que este quadro tem levado a uma produção de "perfis da saúde cada vez mais complexos e padrões de mortalidade em que doenças não transmissíveis e traumatismos aparecem, proeminentemente, enquanto que o peso das doenças transmissiveis diminui relativamente."

Quadro 1 - Indicadores de periodicidade anual de situação de saúde, Brasil, 1990 e 1998.

\begin{tabular}{|l|c|c|c|}
\hline \multicolumn{1}{|c|}{ Periodicidade anual } & 1990 & 1998 & Variação \% \\
\hline Taxa de mortalidade infantil (mil NV) & 49,4 & 36,1 & 26,9 \\
\hline Mortalidade proporcional (60 anos e +) & 49,2 & 53,8 & 9,4 \\
\hline Taxa de mortalidade por homicidios & 22,2 & 25,9 & 16,4 \\
\hline Esperança de vida ao nascer (masculino) & 62,28 & 64,3 & 3,2 \\
\hline Esperança de vida ao nascer (feminino) & 69,09 & 72,3 & 4,7 \\
\hline
\end{tabular}

Fonte: MS/FUNASACENEPI - (SINASC); SIM; E IBGE/ Estimativas Demográficas. Adaptado de VIANNA et al (2001). 
Analisando o quadro acima, observa-se que o valor nacional da taxa de mortalidade infantil, para 1998, é de 36,1 óbitos por 1000 nascidos vivos, ainda muito alto se comparado, por exemplo, à Inglaterra e País de Gales em 1990 cuja taxa era de 8,1 (COHN, 1996). Outro fato a ser destacado a respeito da mortalidade infantil é a desigualdade entre os diferentes estados brasileiros; dos doze estados com taxas acima da média nacional, nove pertencem à região Nordeste e dois à região Norte. PAIXĀO (1997) realizando um trabalho de análise de esperança de vida ao nascer desagregado por etnia e sexo, baseado em dados do IBGE-1997, verifica que:

"A esperança de vida de um homem afro-brasileiro é de 62 anos e a mulher é de 66 anos. No caso dos brancos, entre os homens, esta probabilidade sobe para 69 anos e entre as mulheres para 71. Cabe alertar neste ponto que, apesar de biologicamente a mulher tender a ter uma esperança de vida maior que os homens, tal tendéncia não se verifica no plano das desigualdades raciais no Brasil onde a esperança de vida das afrobrasileiras é 3 anos inferior à esperança de vida dos homens brancos."

Quando se relaciona a taxa de pobreza e mortalidade infantil, em alguns estados brasileiros, as diferenças na distribuição ficam mais alarmantes, como se observa no quadro abaixo.

Quadro 2 -Taxa de pobreza e mortalidade infantil, Maranhão e São Paulo,1998.

\begin{tabular}{|c|c|c|}
\hline Estado & Taxa de Pobreza $^{\star}$ & Mortalidade $^{*}$ Infantil $^{* \star}$ \\
\hline MA & $60 \%$ & 55,7 \\
\hline SP & $12 \%$ & 19,8 \\
\hline
\end{tabular}

Fonte: IDB (Indicadores e Dados Básicos para a Saúde)/RIPSA (Rede Interagencial de Informaçōes Para a Saúde), 2000.

* \% da populaçáo com renda familiar per capita mensal de até 0,5 salário mínimo.

- óbitos em menores de 1 ano / 1000 nascidos vivos 
Quanto ao número de consultas médicas SUS por hab/ano a variação é também muito grande nos diferentes estados brasileiros, enquanto no Pará são feitas 1,25 consultas, no Rio de janeiro este índice sobe para 2,99, sendo a média nacional de 2,19. (VIANNA et al 2001)

No que se refere à cobertura vacinal, os dados mostram que, mesmo para uma intervenção de saúde pública, potencialmente universal, como é o Programa Nacional de Imunizações (PNI), os diferenciais entre estados são expressivos: para a vacina Sabin (anti-poliomielite) a cobertura nacional é de $89,5 \%$, variando entre $128 \%$ em Pernambuco e $49,7 \%$ no Pará; para a vacina anti-sarampo, a cobertura varia de $134,7 \%$ em São Paulo e 65,2 em Alagoas, com média nacional de $108,5 \%$; a cobertura média para DPT(difteria, coqueluche e tétano) é de $78,7 \%$, abaixo, portanto do recomendado (em torno de $95 \%$ ) para impedir a ocorrência de epidemias. (VIANNA et al 2001)

Quanto à saúde bucal, o acesso ao dentista é ainda bastante restrito. Em média $25,2 \%$ de crianças e jovens de 5 a 19 anos nunca procuraram o dentista. Ao analisar a distribuiçăo deste dado por decil de renda domiciliar per capita, a PNAD/1998 mostra que na faixa de renda de até $\mathrm{R} \$ 37,75$ o percentual chega a 50,7

Os dados citados acima, entre outros, justificam a afirmação de MONTEIRO, IUNES e TORRES (1995):

"(...) Reconhecer a tendência geral positiva da agenda tradicional da saúde [doenças infecciosas e carências nutricionais] não significa, evidentemente, assumir como apropriado, e menos ainda como desejável, o quadro epidemiológico atual das enfermidades da pobreza no país. Ao contrário, são inúmeras as evidéncias que indicam que essas enfermidades poderiam, $e$ deveriam, estar mais bem controladas. Entretanto, não é menos verdade que 
muitas tendências documentadas são animadoras e sugerem perspectivas de controle que não costumam frequentar as análises sobre o 'futuro' das doenças da pobreza no Brasil. Trata-se, enfim, de combater os reveses da agenda e de intensificar e estender os avanços obtidos (...)"

Atualmente, assumem destaque na agenda da saúde problemas como violência urbana (homicidios e acidentes de trânsito), uso de drogas, problemas mentais e agravos relacionados às condições ambientais, particularmente à destinação do lixo, qualidade da água e do ar. Cada vez mais, evidencia-se que o enfrentamento destas questões extrapola muito o campo específico da saúde. Tornam-se necessárias as ações intersetoriais. O viver contemporâneo, predominantemente urbano, traz à tona as diferentes dimensões que configuram o fenômeno saúde. Aspectos culturais, educacionais, econômicos, políticos, sociais, ambientais, modelos de consumo, a influência dos meios de comunicação, questões de legislação e juridicas, entre outros, vêm à tona cada vez que se pensa as questões relativas à saúde e à qualidade de vida dos individuos e dos grupos populacionais. O setor saúde tem se deparado, portanto, com a necessidade de repensar suas práticas, revisando o modelo hegemônico (biomédico) de intervenção em função das transformações ocorridas no cenário mundial e, conseqüentemente, brasileiro.

"Tais transformações impactam, de maneira significativa, o campo da saúde, seja ao nivel de seu objeto - o processo saúde-enfermidade de individuos e coletividades - seja ao nivel do instrumental teóricometodológico em que se apóiam o conhecer e o fazer sanitários." (CARVALHO 1996)

Esta citação de CARVALHO mostra duas importantes dimensões de como as questões contemporâneas se relacionam com o campo da saúde. No que se refere ao objeto, cada vez mais se mesclam as formas novas e antigas 
de adoecer. Quanto ao instrumental, são requeridas mudanças nas formas de se desenhar os estudos; não bastam mais dados quantitativos, estes têm que ser acompanhados, respaldados e complementados por análises qualitativas que permitam a incorporação da subjetividade, da diversidade, das diferenças paradigmáticas, da incorporação do social e da interdisciplinaridade, entre outros para compreender o objeto. (ADORNO 1997)

O anteriormente exposto converge para a proposição de SANTOS (1996a) de que: "Os objetos têm fronteiras cada vez menos definidas; são constituídos por anéis que se, entrecruzam em teias complexas com os dos restantes objetos, a tal ponto que os objetos em si são menos reais que as relações entre eles."

O cenário aqui delineado evidencia que a autora deste estudo reconhece a existência de diferenças e a distribuição extremamente desigual dos recursos e bens sociais no Brasil. Ao retratar a saúde considerando as desigualdades econômicas, regionais, étnicas e de gênero, assume-se a compreensão da saúde enquanto um recurso que, também, é decorrente de como os indivíduos e grupos se inserem na sociedade. Por trás desta concepção está a noção de que é preciso propiciar formas de garantir a convivência humana em um mundo mais justo, ou melhor, com justiça social.

Os dados da OPAS/OMS (1998a) citados a seguir, fundamentam-se no relatório do PNUD (Programa das Nações Unidas para o Desenvolvimento e IPEA (Instituto de Pesquisa Econômica Aplicada) sobre disparidades socioeconômicas (1996) e permitem afirmar que o Brasil é um dos países do mundo onde há maior desigualdade.

“Em anos recentes, o crescimento da economia elevou a renda média em todos os estratos da população, mas a distribuição desigual fez aumentar as 
diferenças preexistentes. A renda média dos $10 \%$ mais ricos é de cerca de 30 vezes a dos $40 \%$ mais pobres, enquanto que em outros paises com grau de desenvolvimento comparável ao do Brasil é apenas 10 vezes maior. Os $50 \%$ mais pobres tiveram, entre 1960-1990, sua participação na renda nacional reduzida de $18 \%$ para $12 \%$, enquanto a dos $20 \%$ mais ricos elevouse de $54 \%$ para $65 \%$, no mesmo periodo. (...) Ao longo da década, a população de 0-17 anos vivendo em domicílios chefiados por mulheres aumentou de $9 \%$ para $13 \%$.(...)"

Mesmo que tenha aumentado a participação da mulher na população economicamente ativa, o salário médio dela ainda corresponde a $63 \%$ do recebido pelos homens. A diminuição das desigualdades nas oportunidades de acesso a uma ocupação remunerada, advindas do aumento da escolaridade feminina e da luta das mulheres pelas mudanças de costumes na sociedade brasileira, não foi suficiente para uma distribuição mais equânime de renda e de cargos de maior hierarquia entre homens e mulheres.

Com este olhar buscou-se em SANTOS (1996b) um contraponto para desvelar e compreender o objeto deste estudo. Para o referido autor, a sociologia (aqui entendida enquanto ciência):

"Tem oscilado entre a distáncia crítica em relação ao poder instituido e o comprometimento orgânico com ele, entre o guiar e o servir. Os desafios que nos são colocados exigem de nós que saiamos deste pêndulo. Nem guiar nem servir. Em vez de distáncia crítica, a proximidade crítica. Em vez de compromisso orgânico, o envolvimento livre. Em vez de serenidade autocomplacente, a capacidade de espanto e de revolta."

Durante o processo de elaboração deste estudo, vivenciando vários eventos da área em investigação, desenvolver uma "proximidade crítica" constituiu uma tarefa difícil. Mesmo envolvida na ação de pesquisadora, muitas 
vezes, foi flagrante a tendência de se situar em um dos extremos do "pêndulo". ora idealizando, ora mantendo-se impassivel. As idéias difundidas tinham o poder de convocar todos que não haviam perdido a capacidade de indignação diante dos altos indices da exclusão social no Brasil. Nos diferentes fóruns não havia quem se manifestasse contrário à pertinência das proposições dos difusores da promoção da saúde. Nestas ocasiões, as discussões apontavam para uma necessária politização da saúde. As dificuldades emergiam, na medida que, os profissionais da saúde, relatavam não identificar as questões especificas a serem enfrentadas pelo setor.

No Brasil, o movimento de saúde ou movimento sanitário da década de 80, foi caracterizado por JACOBI (1989) como movimento social urbano. Este tipo de movimento, segundo o autor citado, não agiu "no sentido de transformar a sociedade, imprimindo-lhe um sentido novo, mas atuam, principalmente, como grupos de pressão sobre o Estado, no sentido de obter respostas concretas às suas demandas, através de dinámicas diferenciadas, porém pautadas por um maior ou menor enquadramento institucional."

A partir de uma noção compartilhada de "carências e necessidades" uma articulação de ações sociais (lideranças populares, profissionais e religiosas) e, posteriormente, através da ocupação de cargos na estrutura do Estado, consegue-se deixar como legado para os anos 90: "a saúde como um direito de todos e dever do Estado". Ainda, amplia-se a transparência da gestão da saúde garantindo a criação de mecanismos legais para o controle público do setor. Nas palavras de COSTA (1989), foi "gestada uma nova relação entre Estado e as camadas populares". Este movimento social foi e tem sido estudado por diferentes autores (ALMEIDA 1989; COSTA 1989; GERSCHMAN 1995;

\footnotetext{
- Segundo MINAYO (1999): “Dados o crescimento demográfico e a condução histórica do capitalismo, uma multidăo sem precedentes de seres humanos passou a não fazer parte, antecipadamente, da partilha dos bens sociais e da riqueza gerada pelo desenvolvimento
} 
TEIXEIRA 1995; ESCOREL 1998), é comentado por vários participantes desta pesquisa, e merece destaque, nesse capítulo introdutório, por subsidiar elementos para a análise do movimento de promoção da saúde aqui investigado.

O movimento constituido pelos difusores da promoção da saúde, com origem na década de 90 , pretende e convoca profissionais em busca de um vir a ser para a saúde pública brasileira. Com a expectativa de identificar se este movimento pode ser considerado um movimento social, definiu-se como um dos objetivos deste trabalho sua caracterização.

\section{Segundo HEYWOOD (1997):}

"Um movimento social é uma forma particular de comportamento coletivo na qual o motivo da ação se espalha largamente a partir das atitudes $e$ aspirações dos membros, tipicamente agindo dentro de um tênue padrão de organização. Fazer parte de um movimento social requer um nivel de comprometimento e ativismo político mais que uma carteininha formal de membro do movimento; acima de tudo movimento move. Um movimento é diferente de uma ação espontânea de massa (tal como uma rebelião) na qual implica a existência de um nível de ação intencional e planejada da direção de uma meta reconhecida."

Para se caracterizar a existência de um movimento social se requer que a ação coletiva possua uma inserção ou base social, possua também um ideário comum, que seus participantes compartilhem de uma "noção de carências e necessidades", ou daquilo que é inaceitável. É preciso também que 
seus participantes concordem e assumam as mesmas estratégias e meios como os desejáveis para que a meta comum seja atingida.

De acordo com TOURAINE (1980), "um movimento social não é a expressão de uma intenção ou uma concepção de mundo. Não é possivel falar de movimento social se não se pode, ao mesmo tempo, definir o contramovimento ao qual ele se opõe."

A categoria movimentos sociais vem sendo utilizada para explicar uma série de ações coletivas ocorrendo fora da esfera de produção. TOURAINE (1980, 1989, 1994) desenvolveu uma grande quantidade de estudos sobre movimentos sociais. Do conjunto do seu trabalho, destaca-se a preocupação em distinguir os movimentos de protesto ou reivindicatórios daqueles que se caracterizam realmente como movimentos sociais. Para ele os movimentos reivindicatórios se orientam para a satisfação de necessidades pontuais de bens materiais e se definem pelo caráter defensivo das condiçōes de trabalho (greves, manifestações públicas de categorias, sejam de iniciativa estatal ou privada). Já, os movimentos sociais tratam da construção da identidade de "minorias" sociais, ou seja, se constituem de atores sociais que entram em conflito pelo domínio da historicidade, assumindo em suas mãos a direção da sociedade, determinando os rumos que esta deve tomar. Mas, estes dois tipos de movimentos têm um ponto em comum: ambos pretendem mudanças no âmbito da ordem institucional e, assim, são forjadores da ampliação do espaço político da democracia.

Analisando os anos 90, TOURAINE (1994) afirma que: "A consciência moral, que está no âmago dos novos movimentos sociais, está mais intimamente ligada à defesa da identidade e da dignidade daqueles que lutam contra uma opressão extrema ou contra a miséria do que às estratégias 
politico-sociais de sindicatos ou de grupos de pressão que hoje fazem parte do sistema de decisão dos paises ricos."

LABONTÉ (1994) ao discutir sua visão sobre a promoção da saúde no Canadá, afirma que: "promoção da saúde é um conceito inevitavelmente contestável, significando várias coisas para as várias pessoas que o usam." Um dos significados que ele pôde identificar junto aos profissionais da promoção da saúde, foi o de que é: "um movimento social preocupado ou envolvido com os pré-requisitos da saúde, tais como: paz, abrigo, comida, renda, ecossistema sustentável, justiça social e equidade."

No Brasil, já há quem advogue esta visão, conforme se observa na citação abaixo: "A promoção da saúde é, antes de mais nada, um movimento social e de profissionais da saúde que surge como reação à acentuada medicalização da saúde na sociedade e no interior do sistema de saúde." (BUSS 1998)

Diante desta rede de circunstâncias que configura o desenvolvimento da promoção da saúde, no Brasil, buscou-se, então, neste estudo, identificar o que os participantes dizem do movimento do qual fazem parte e qual o significado que atribuem a ele.

Situados em um país onde direito é privilégio, onde nem se consolidaram os direitos garantidos em lei e já se nega a legitimidade de muitos deles, vivendo tempos de questionamento da capacidade do Estado para garantir uma gestão mais equânime dos recursos, bens e serviços, a saúde aparece como um "elemento potencial de consenso, a forma de distribuição desse 'direito consensual' é que é motivo de dissenso." (TEIXEIRA 1995) 


\section{OBJETIVOS}

\subsection{Objetivo Geral}

Compreender como foi construido e implementado o movimento de promoção da saúde no Brasil, na década de 1990, a partir da opinião de profissionais difusores e dos documentos mais significativos da área.

\subsection{Objetivos Específicos}

- Caracterizar os profissionais difusores da Promoção da Saúde;

- Verificar onde e como os sujeitos pesquisados entraram em contato com o conceito de Promoção da Saúde;

- Verificar se essas pessoas frequentaram programas formais de ensino visando adquirirem habilidades técnicas que thes permitam operacionalizar atividades na área da Promoção da Saúde;

- Conhecer os conceitos apresentados sobre os termos "Educação em Saúde" e "Promoção da Saúde";

- Identificar elementos que favoreceram a entrada do referencial da Promoção da Saúde na realidade brasileira; 
- Caracterizar o movimento da Promoção da Saúde no Brasil;

- Descrever como tem sido difundida a Promoção da Saúde no Brasil e quais as principais estratégias adotadas;

- Identificar os setores responsáveis pela implementação das práticas da Promoção da Saúde. 


\title{
4. PROCEDIMENTOS METODOLÓGICOS
}

\author{
"Vendo a história como um campo de possibilidades, \\ visualizam-se, em cada momento, diferentes propostas em jogo \\ e se uma delas venceu, venceu não porque tinha que vencer, \\ mas por uma série de injunções que é preciso desvendar."
}

(VIEIRA et al 1989)

\subsection{Natureza do estudo}

Para a realização deste estudo recorreu-se a uma pesquisa do tipo qualitativa, sendo os dados levantados a partir da realização de entrevistas semidiretivas junto a profissionais de saúde que estão difundindo a promoção da saúde na realidade brasileira e do diálogo destas com as Cartas e Declarações das Conferências Intemacionais da área.

Entende-se por estudo qualitativo aquele "capaz de incorporar a questão do significado e da intencionalidade como inerentes aos atos, às relacões $e$ às estruturas sociais", sendo estas últimas tomadas tanto no seu advento quanto na sua transformação, como construções humanas significativas." (MINAYO 1994a)

Grifo presente no original. 
De acordo com MINAYO (1994b): “(..) a abordagem qualitativa aprofunda-se no mundo dos significados das ações e relações humanas, um lado não perceptível e não captável em equações, médias e estatísticas."

Com o interesse de investigar as expectativas, intencionalidades e significados atribuidos ao referencial de promoção da saúde pelos profissionais de saúde, considerou-se que essa tarefa poderia ser realizada utilizando a abordagem qualitativa, pois segundo MARTINS e BICUDO (1989):

"A forma pela qual os dados são coletados na pesquisa qualitativa é a da comunicação entre sujeitos e o tratamento dos dados é feito através da interpretação. (...) É compreendida (a interpretação) como um modo de ajuizar o sentido das proposições que levam a uma compreensão ou aclaramento dos sentidos e significados da palavra, das sentenças e dos textos."

A coleta dos dados foi realizada em duas etapas. A primeira diz respeito à seleção, leitura e discussão dos principais documentos da promoção da saúde que circulam entre os estudiosos da área. A segunda, prendeu-se à realização de entrevistas junto a profissionais de saúde que têm participado mais intensamente no movimento de promoção da saúde no Brasil.

Foram selecionados dois tipos de documentos:

- Cartas e Declarações das Conferências Internacionais de Promoção da Saúde: Carta de Ottawa, Canadá, 1986; Declaração de Adelaide, Austrália, 1988; Declaração de Sundsvall, Suécia, 1991; Declaração de

- Grifos presentes no original. 
Bogotá, Colômbia, 1992; Declaração de Jacarta, Indonésia, 1997; Declaração Ministerial do México, México, 2000 e

- publicações (nacionais e internacionais) que comentam ou analisam o movimento em questão.

Foi realizada, inicialmente, uma leitura dos conceitos teóricos divulgados nos referidos documentos com o objetivo de identificar os caminhos sugeridos nestes para a viabilização das propostas de promoção da saúde. Os caminhos informam os "contornos dos conceitos" ou apontam as "palavras-chaves" utilizadas para o cumprimento das intenções. Durante a leitura exploratória das declarações das Conferências pôde-se observar que, algumas vezes, estas se preocupam em qualificar ou distinguir os conceitos utilizados; outras vezes utilizam o recurso de "associação e/ou oposição de idéias" sem atentarem para a tradução dos mesmos.

Este tipo de leitura possibilita, também, identificar a quem se destinam as propostas destes documentos. As "prescrições" destas "cartas de intenções" são endereçadas a homens, mulheres, instituições, governos? As proposições incluem os sujeitos que a viverão? Pretendeu-se discriminar os sujeitos nelas referidos direta ou indiretamente, seja para viabilização ou execução das intervenções; seja para ser beneficiário das propostas de promoção da saúde.

Realizar o exercício de "pensar os documentos enquanto portadores de um projeto especifico apresentado como universal", se constituiu uma aprendizagem fundamental no processo de construção deste estudo (VIEIRA et al 1989). Investigou-se se os documentos têm sido problematizados, visando a

\footnotetext{
- VIEIRA et al (1989) ensinando sobre o pesquisar em história, ao relatarem sobre a utilizaçăo de uma determinada técnica de leitura de documentos, descreveram que:

"(...) havia algumas palavras que tinham um importante papel no processo de ocultaçăo do especifico, funcionando como uma espécie de artificio ou artimanha que favoreciam a generalizaçăo do projeto, as convencionamos chamar 'palavras-chaves'".
} 
construção de um campo de referência conceitual. Ou, se estes têm sido, meramente, traduzidos como modelo operacional pelos participantes do movimento de promoção da saúde. Compreendê-los como um modelo operacional (assumirem o status de), implicaria na importação acrítica de propostas internacionais e as falas dos difusores reproduziriam, mecanicamente, os documentos oficiais.

As Declarações, enquanto protocolos de realizações, assumem aparência de consenso e não traduzem a riqueza do processo de construção, nem os conflitos de interesse a que foram submetidos. Reconhece-se que, para investigar o que está dito nas entrelinhas, exigiria mais tempo e extrapolaria os prazos limites desta pesquisa. Contudo, por estes documentos mostrarem diretrizes de atuação para a prática de promoção da saúde, justifica-se a análise realizada neste estudo.

Após a análise dos documentos, teve-se como objeto de estudo o depoimento dos profissionais que difundiram e/ou estão difundindo a Promoção da Saúde no Brasil. Para que na obtenção dos depoimentos fossem abordados os temas que constituiam interesse para este trabalho, utilizou-se um roteiro de entrevista semidirigida ou semi-estruturada (anexo 1) como definida por QUIVY e CAMPENHOUNDT (1992):

"A entrevista semidiretiva ou semidirigida é certamente a mais utilizada em investigação social. É semidiretiva no sentido em que não é nem inteiramente aberta, nem encaminhada por um grande número de perguntas precisas. Geralmente, o investigador dispõe de uma série de perguntasguias, relativamente abertas, a propósito das quais é imperativo receber uma informação da parte do entrevistado. Mas não colocará, necessariamente, todas as perguntas na ordem em que as anotou e sob a formulação prevista. Tanto quanto possivel, 'deixará andar' o entrevistado para que este possa 
falar abertamente, com as palavras que desejar e na ordem que the convier. O investigador esforçar-se-á simplesmente por reencaminhar a entrevista para os objetivos, cada vez que o entrevistado deles se afastar, e por colocar as perguntas às quais o entrevistado não chega por si próprio, no momento mais apropriado e de forma tão natural quanto possivel."

O roteiro temático da entrevista foi constituido por 19 questões, que são discutidas a seguir.

A primeira questão solicitava que $\circ$ (a) entrevistado (a) falasse um pouco de sua trajetória no setor saúde. O propósito foi o de que a expressão da história pessoal ou a análise do seu conjunto de experiências na saúde pública revelasse elementos que pudessem informar ou sinalizar a origem do interesse destes pela área de promoção da saúde. Para orientar esta narrativa, pediu-se que estes relatassem os fatos mais marcantes nesta trajetória profissional, conferindo a eles a possibilidade de "valonização subjetiva dos detalhes". (MEIHY 2000)

Indagou-se, na segunda pergunta, onde e como os pesquisados conheceram o conceito de Promoção da Saúde e em que contexto (momento) da vida profissional destes se deu a aproximação à Promoção da Saúde, bem como se aconteceu algo na vida profissional destes sujeitos que propiciou adotar ou avançar esta idéia. Partiu-se do pressuposto de que o relato da experiência individual pudesse indicar se havia ocorrido influências da instituição em que eles trabalham ou dos seus pares para acolher este conceito, ou de que outra forma os entrevistados foram se envolvendo com o conceito de promoção da saúde.

A terceira questão pretendeu identificar quais leituras ou pesquisas contribuiram, influenciaram ou despertaram 0 interesse pela Promoção da 
Saúde. Indagou-se ainda se para eles ou elas a Promoção da Saúde tem se diferenciado ao longo do tempo.

$\mathrm{Na}$ quarta questão, buscou-se a opinião deles sobre quais os valores ou idéias que despertaram por aqui o interesse pela promoção da saúde, na década investigada. A intenção foi a de obter elementos para identificar o que favoreceu a entrada deste referencial no contexto brasileiro.

A quinta questão proposta neste trabalho disse respeito ao significado de Promoção da Saúde para os pesquisados. Trata-se de um conceito, estratégia ou constitui uma "nova" prática na saúde?

As perguntas 6 e 7 procuravam informações sobre os objetivos da Promoção da Saúde e sobre as estratégias delineadas para atingi-los.

Ao investigar, na oitava questão, se, na atualidade, eles têm trabalhado em atividades relacionadas com a Promoção da Saúde, pretendeu-se saber se tem havido financiamento destinado especificamente a essa área. A identificação do tipo de trabalho desenvolvido (capacitação, cursos, pesquisa, assessoria de planejamento de programas) e da(s) fonte(s) financiadoras pode auxiliar na informação de como tem se difundido a Promoção da Saúde no Brasil e quais as principais estratégias adotadas, assuntos que foram temas das questões 10 e 11.

Sabendo da freqüente confusão existente, por parte dos profissionais da saúde, entre os significados de Educação em Saúde e de Promoção da Saúde, buscou-se, também, identificar na questão 9 se e como os pesquisados os distinguem. 
Nas questōes 12 e 13, o propósito foi de, respectivamente, identificar se os depoentes mantêm relaçōes entre si, como as mantêm e se estas se dão mediadas por outros grupos ou instituiçōes e, ainda, identificar os fóruns ou eventos nacionais e internacionais, com a temática da Promoção da Saúde, que eles participaram.

A identificação das expectativas que os pesquisados têm com a difusão da Promoção da Saúde pretendeu dar subsidios para informar a intencionalidade que tem orientado esta prática, o que foi objetivo da questão 14.

Fazendo um elo com as proposições dos documentos oficiais para a implementação das ações de promoção da saúde, procurou-se, na décima quinta questão, a opinião dos difusores sobre quais os setores eles consideram responsáveis para o desenvolvimento desta prática em nosso meio.

Pretendeu-se, também, nas perguntas 16 e 17, levantar, junto aos pesquisados, quais os principais obstáculos e aspectos facilitadores, que têm identificado para a difusão da Promoção da Saúde no Brasil.

A questão 18 diz respeito à opinião dos entrevistados sobre o "movimento" da promoção da saúde na atualidade. Que movimento é esse? Pode ser identificado como um movimento social?

Ao final do roteiro, na décima nona questão, destinou-se um espaço para que $o$ (a) entrevistado (a) fizesse algum comentário ou introduzisse um tema que considerasse pertinente ao estudo do qual estava participando e que não houvesse ainda sido abordada durante a entrevista. 
MARTINS e BICUDO (1989) ao tecer considerações sobre o uso da entrevista na pesquisa qualitativa, alertam para o fato de que:

“Abordar o entrevistado e convidá-lo a participar de um projeto pressupõe uma apreciação dele a respeito dos objetivos $e$, até certo ponto, da utilidade social do projeto. É importante que o entrevistado se veja como um elemento útil no estudo, capaz de emitir opiniões sobre a questão que está sendo investigada."

Portanto, desde o primeiro contato (solicitação da entrevista), procurouse esclarecer os critérios da seleção para participar da pesquisa, bem como o objetivo da mesma. Também, julgou-se necessário solicitar a autorização por escrito (Anexo 2) deste (a) para que sua participação ou informações dadas fossem gravadas, identificadas ou descritas em parte ou na íntegra, no texto final da pesquisa.

O critério para inclusão das doze pessoas entrevistadas neste estudo se deu em função do papel por elas desempenhado, reconhecimento ou relevância a elas atribuidas, na área da promoção da saúde. Foi solicitado à Profa Márcia WESTPHAL (1997b, 1998b), reconhecida difusora da promoção da saúde, no Brasil, que formulasse uma lista inicial, a partir da qual todos os incluidos tivessem a oportunidade de sugerir ou indicar novos informantes.

Este estudo foi delineado a partir de uma amostra intencional constituida por dez entrevistados. Dois participantes foram adicionados, posteriormente, por sugestão dos difusores. A observação da Lista de Informantes (Anexo 3) permite avaliar as dificuldades encontradas para localizar pessoas residentes em diferentes Estados, Rio de Janeiro, São Paulo, Ceará, Minas Gerais, Distrito Federal, e que atuam em distintos espaços ou instituições dentro e fora do Brasil. 
Para registrar o desenvolvimento da pesquisa e complementar as informações obtidas durante os depoimentos, a autora se propôs organizar um diário de campo para: "anotar as ênfases feitas, expressões faciais, sinais de alívio e preocupação e outros gestos (...)" (DALTON apud CICOUREL 1980).emitidos pelos pesquisados e, ainda, para registrar as idéias, os sentimentos da pesquisadora (confusão, medos, satisfação, dificuldade), expressões ou conceitos que requerem ser melhor investigados e descrições esclarecedoras ocorridos durante os encontros com sujeitos. Esperava-se que a leitura e análise deste instrumento pudessem informar o processo de desenvolvimento da pesquisa, favorecer uma ação reflexiva e confrontar a subjetividade da pesquisadora.

Segundo JOUTAR (1998):

"Reconhecer tal subjetividade não significa abandonar todas as regras e rejeitar uma abordagem científica, isto é, a confrontação das fontes, o trabalho crítico, a adoção de uma perspectiva. Pode-se mesmo dizer, sem paradoxo, que o fato de reconhecer sua subjetividade é a primeira manifestação do espirito crítico."

Considera-se importante evidenciar que os depoimentos não foram complementares aos documentos com função, meramente, ilustrativa. $\mathrm{Na}$ verdade, assumiram o mesmo status: unidade ou elemento nuclear de análise. Procurou-se estabelecer um caráter dialógico entre ambos orientado pelas reflexões de LOZANO (1998):

"Esses pesquisadores da oralidade (sejam historiadores, antropólogos, sociólogos etc.) consideram a evidência oral uma fonte muito importante e, em vários casos, a única ou a medular, mas que afinal é só mais um dos 
meios e acervos de informação de que dispõe o pesquisador para a construção da percepção, no tempo e no espaço, da experiência humana, particularmente dos grupos sociais em que a oralidade se mantém em vigência.

Essa postura, que combina e conjuga acertos e propostas dos diferentes estilos examinados, sustenta que a versão da história da sociedade que se constrói é tão válida quanto aquela que deriva da consulta de fontes documentais como arquivos e registros fiscais ou policiais, por exemplo. Não obstante, a evidência oral também exige e deve ter a mesma receptividade $e$ os mesmos controles críticos que se aplicam aos artigos de jornal, a um relatório político ou a um documento lavrado em cartório."

" Grifo no original. 


\subsection{Usos dos Instrumentos de Pesquisa}

Ao final, os instrumentos selecionados para o desenvolvimento das entrevistas foram: roteiro temático da entrevista individual (anexo 1); declaração ou termo de consentimento com explicitação dos objetivos da pesquisa e dos usos dos depoimentos (anexo 2); gravador e fitas k7; diário de campo.

As 12 entrevistas foram realizadas no periodo de agosto de 1999 a fevereiro de 2001 , sendo as datas e locais marcados pelos entrevistados. $O$ fato dos participantes serem residentes e participarem de vários eventos e atividades profissionais nas diferentes regiões do país, fez com que o tempo de realização deste trabalho se alongasse e os custos fossem aumentados em função da necessidade do deslocamento da pesquisadora para se adequar às agendas dos entrevistados. É preciso considerar também as várias vezes em que as entrevistas tiveram que ser remarcadas devido aos imprevistos surgidos com os entrevistados.

Após um contato inicial por telefone, a entrevista era agendada. Todos foram bastante solícitos, sendo que alguns, visando diminuir a distância do deslocamento da pesquisadora, sugeriram que a entrevista fosse feita durante algum evento da área, em um momento de maior disponibilidade. Esta estratégia se mostrou bastante adequada, pois, foi possivel realizar seis entrevistas em duas viagens.

O local da entrevista foi o mais variado possivel: Salão de Café, varanda, salas de reuniões de Hotel; piano bar do Aeroporto Internacional de Brasília; biblioteca da residência de uma das entrevistadas; escritórios e salas de 
reunião dos diferentes locais de trabalho dos entrevistados. Apesar da variedade de locais e do fato de não se dispor da privacidade adequada, o roteiro das entrevistas foi cumprido integralmente em todos os casos.

A duração média das entrevistas foi de 55 minutos, sendo a mais curta de 28 minutos e a mais longa de 1 hora e 20 minutos. Provavelmente, um dos fatores que influiu foi o fato de que na primeira, o entrevistado tinha uma vivência mais recente na área, com menos de 10 anos de saúde pública; enquanto na segunda, a entrevistada, atuava na área desde o final da década de 50. Foi dado destaque ao tempo de atuação na área de saúde pública após se verificar o quanto a trajetória profissional, resgatada na primeira questão da entrevista, influenciou no repertório de experiências e reflexões sobre o movimento da promoção da saúde, da década 90 , na saúde pública brasileira.

A leitura das anotações do Diário de Campo evidenciou o quanto este foi utilizado antes e ao final das primeiras entrevistas, sendo abandonado ao longo do processo da realização das últimas.

Durante as entrevistas não foi registrada nenhuma informação no diário de campo, pois a pesquisadora se ocupava em estabelecer um vínculo e buscar os nexos existentes entre os temas estudados e as informações relatadas sobre a história da saúde pública brasileira. Estas emergiram, principalmente, quando o olhar do entrevistado se voltou para a sua trajetória pessoal.

TOURTIER-BONAZZI (1998) ressalta alguns aspectos que foram considerados relevantes no momento de ida ao campo e realização das entrevistas, entre eles o fato de que: "(...)Quando se fala em 'colher depoimentos orais, costuma-se privilegiar a testemunha, defendendo-se uma atitude passiva diante de um discurso autônomo, pois basta colher informações. Falando da 'criação de fontes orais', ao contrário, valoriza-se o trabalho do 
entrevistador, como se este fabricasse a recordação a partir do caos, quando na realidade não faz senão suscitá-la.(....)"

A subjetividade e as emoções emergiram através da recordação de fatos e encontros de pessoas marcantes, as quais possibilitaram que a relação entrevistadora-entrevistado fosse mais dialógica e menos "inquisitora".

Este fato corrobora a visão de BÉRIDA (1998), no seu texto sobre "Tempo presente e presença da história":

"(...) Se a história - quanto a isso estamos todos de acordo - não tem vocação para ser nem um tribunal nem um pódio de distribuição de prêmios, ainda assim impóe-se desde logo a questão dos valores e da relação entre ciência e ética. Como elaborar uma história do tempo presente sem tudo julgar, ainda mais que essa história se define tanto em relação a um futuro quanto em relação a um passado?"

A questão referente à história de vida dos entrevistados permitiu estabelecer uma teia onde as conexões evidenciam que vários dos informantes trabalharam ou se relacionaram ao longo das suas histórias de vida. Oriundos de diferentes regiões do Brasil se conectam, dentro e fora do país, para traçar muito do que hoje se tem como fruto da Reforma Sanitária Brasileira.

Vale ressaltar que a opção feita neste estudo em transitar e recorrer ao arsenal teórico e metodológico da história e da antropologia mostrou-se valiosa. O exercício de introduzir estes olhares no campo da saúde pública investigado permitiu evidenciar que os entrevistados conformam um grupo de pessoas que podem ser compreendidos como uma "comunidade científica". Como tal, segundo PONTES (1997): "As relações que unem seus integrantes são, a um só tempo, sociais, morais, politicas, pessoais e, em vários casos, conjugais. 
Seus membros não apenas 'envelhecem juntos' como tendem a aparecer sob a forma de personagens nas biografias de vários deles. (...)"

Alguns fragmentos das entrevistas trouxeram à luz dimensões que são, geralmente, desconsideradas no cotidiano das práticas do setor e das suas instituições. O público, o coletivo, a população - objetos da saúde pública, na maioria das vezes, favorecem a coisificação das pessoas que com ela trabalham. Estas são abordadas como coisas, sem nome, sem singularidades, onde o que importa é o cumprimento das normas, das portarias, medidas gerais que determinam o fazer na saúde.

Este estudo é profícuo em evidências da influência do espaço do micro na macro-estrutura ou do espaço da criação humana, dos interesses e valores pessoais na determinação e estruturação das instituições ou sistemas. Ressalta-se aqui o valor de autores (CAMPOS 1997; L'ABBATE 1997; DUARTE 1998; ALVAREZ 1999) que têm aceitado o desafio de destinar tempo e empenho para a não compartimentalização destas esferas na compreensão do agir cotidiano da saúde. 


\subsection{Processo de Transcrição das Entrevistas e Definição das Categorias de Análise}

A transcrição das fitas ou a passagem da gravação oral para o escrito requereu mais tempo do que o inicialmente planejado. Foi necessário contratar os serviços de uma digitadora para finalizar este processo. Mas, mesmo não tendo transcrito todas as 12 gravações, a pesquisadora ouviu, várias vezes, todas as fitas e corrigiu pontuação e terminologias, pois só quem participa da produção destas se aproxima do ritmo e sentidos narrados.

Segundo MEIHY (2000):

"Faz-se necessário ouvir muitas vezes a entrevista até que se defina 'a música' do relato. Depois de absonvido o ritmo da narrativa e a intenção, procede-se à transcrição, que, numa primeira etapa, deve ser fiel ao acontecido. Vícios de linguagem, erros de gramática, palavras repetidas devem ser corrigidas, mas sempre indicando ao leitor, que precisa estar preparado. Sugere-se que palavras ou expressões repetidas, como 'né', 'sabe', 'daí por diante' e 'depois disso' devam ser mantidas em dose suficiente para o leitor sentir o tipo de narrativa ou sotaque."

TOURTIER-BONAZZI (1998) sugere algumas regras para tornar o texto transcrito mais claro:

"-As passagens pouco audiveis podem ser colocadas entre colchetes.

-As dúvidas, os silêncios, as rupturas sintáticas, assinaladas por reticências.

-As pessoas citadas, se for necessária descrição, designadas por iniciais. 
-As palavras usadas com forte entonação serão grafadas em negrito.

- O texto será organizado cuidadosamente em parágrafos, devendo-se atentar para a pontuação, que é imprescindivel à boa compreensão do texto. -Os subtítulos podem facilitar a leitura.

-Serão corrigidos em notas os erros flagrantes por parte dos entrevistados. datas, nomes próprios etc."

Ao final da transcrição das entrevistas passou-se a sua leitura com atenção flutuante. Pouco a pouco foram emergindo afinidades e divergências de visōes, "coincidências" que aproximam os entrevistados e conceitos que já constavam no desenho do projeto desta pesquisa.

As evidências estão espalhadas, dispersas nas falas. Cabe ao pesquisador, neste momento, voltar ao projeto e direcionar o seu olhar para as perguntas que o impulsionaram a escolher aquela metodologia. As advertências recebidas em sala de aula são, agora, bastante apropriadas: "Não vai quantificar os depoimentos, a natureza do seu estudo é qualitativa. Um não falou! O mais importante é se perguntar: de onde ele fala?"

A releitura do projeto permitiu o reconhecimento de que algumas categorias emergentes, nas primeiras leituras das entrevistas, constituiam conceitos presentes na problemática do projeto, o que auxiliou na determinação das categorias intrínsecas ao objeto de estudo.

Foi feita, então, uma leitura horizontal das entrevistas procurando identificar a presença ou não dos temas registrados nas leituras anteriores. Estes temas foram agrupados procurando estabelecer as primeiras unidades de

\footnotetext{
- Anotações das aulas da disciplina Fundamentos da Investigação Científica, ministrada pela Prof" Maria da Penha Vasconcelos, setembro de 1998, na FSP/USP.
} 
análise". Estas unidades foram sublinhadas no texto transcrito e embasaram a posterior construção das categorias de análise

Estes significados, dialogados e confrontados com os dados da análise dos documentos permitiram visualizar o momento em que os entrevistados somente reproduzem as proposições das Declarações e o momento que eles já têm uma leitura própria do que vem a ser a promoção da saúde na realidade brasileira.

Este procedimento se repetiu inúmeras vezes até o esgotamento de possibilidades de identificação das categorias. Isto é, o que a pesquisadora conseguiu realizar até o momento. As gravações com as respectivas transcriçōes serão doadas para o Acervo Iconográfico da Faculdade de Saúde Pública da Universidade de São Paulo - FSPIUSP, visando disponibilizá-las para os que se interessarem futuramente pelo tema.

Algumas frases das questões que constituíram o roteiro de entrevista serviram de epígrafe para orientar a leitura e discussão dos resultados. Ao final, as unidades de análise ou categorias foram assim identificadas:

- perfil dos entrevistados;

- momento da vida profissional em que os difusores se aproximaram do referencial da Promoção da Saúde;

- conceitos associados à Promoção da Saúde;

- bases conceituais do movimento de Promoção da Saúde;

- distinção entre Promoção e Educação em Saúde;

\footnotetext{
Segundo LAVILLE e DIONNE(1999), "as unidades de análise serăc ainda palavras, expressరes, frases ou enunciados que se referem a temas, mas esses elementos, em vez de serem enumerados ou medidos, serăo vistos em funçăo de sua situaçăo no conteúdo, em funçăo do conjunto dos outros elementos aos quais vêem-se ligados e que thes fixam o sentido e o valor."
} 
- elementos que favoreceram a entrada da Promoção da Saúde na década de 90, no Brasil;

- estratégias de difusão da Promoção da Saúde no Brasil;

- caracterização do movimento de Promoção da Saúde no Brasil;

- setores responsáveis pela implementação das ações de Promoção da Saúde no Brasil. 


\section{OS PARTICIPANTES DA PESQUISA}

\subsection{Os Entrevistados}

Os doze participantes deste estudo estão intimamente relacionados ao setor saúde; sendo que 8 (oito) se graduaram em medicina e 3 (três) em odontologia. O estudo inclui também uma pedagoga, considerando que sua trajetória profissional se deu, essencialmente, em atividades acadêmicas dessa área. Essa, também, foi a única entrevistada que não atuou na administração de serviços de saúde. Os cargos assumidos pelos demais variaram de diretor de unidade de saúde à direção de regional e de secretário municipal a ministro da saúde.

Em relação à pergunta 1, pediu-se que os entrevistados dissessem alguma coisa a respeito de suas trajetórias no setor saúde.

Seis dos entrevistados consideraram relevante, para sua formação terem militado no movimento estudantil e, também, terem participado de estágios extra-muros e internatos rurais. Pode-se exemplificar com as falas abaixo:

L.A.. "Primeiro, eu sou da geração que, digamos, estava na escola secundária no momento de transição política. Já na, digamos, na escola secundária, eu tive contato então com a política estudantil. Fui membro do movimento secundarista. Ao ingressar na Universidade, continuei com a minha militância 
política e sempre fui muito empolgado com a Medicina. Sempre gostei da saúde, mas sempre, também, fui uma pessoa com uma, digamos... Sempre gostei muito da área de ciências sociais: sempre gostei muito de história, sempre gostei muito de geografia, sempre gostei mais dessa discussão, digamos, sobre a questão do conhecimento da questão da área de humanas. $E$ isso, de certa forma, coincidiu com um momento muito interessante de quando a gente estava na Universidade. Também participamos de um espaço privilegiado, no Brasil, que foi o nascimento do movimento sanitário. Então, dentro da Universidade, nós tínhamos uma discussão importante sobre a questão curricular. Nesse processo todo eu participei de todos os Encontros Cientificos do Estudantes de Medicina, na minha época os ECEM. Fui presidente de um ECEM, que foi um ECEM muito especial. Foi o ECEM de 1986. Eu fui Delegado da UNE na Oitava Conferência. A UNE teve cinco Delegados no Brasil todo, na cota dos Delegados. Dos cinco mil Delegados da Oitava Conferéncia a UNE tinha o que? 1\% (por cento), que seria 5 Delegados e desses 5 Delegados eu fui um dos Delegados da UNE. E foi um momento privilegiado. Assim que eu tive contato com todas as lideranças, com todas aquelas grande lideranças nacionais que participaram daquele momento rico, discussão da Nova República, a CUT se emergindo, o movimento da Zona Leste de São Paulo(...).

Isso tudo para mostrar alguns fatos que dentro da minha vida estudantil foram muitos importantes. Bom, depois vem a história do internato(...)"

A.V. "Ai se dá conta que o saber médico não é suficiente e que se precisa de outros conhecimentos... desde o meio ambiente, da saúde pública, como se organizar comunidade e aí vai-se aprendendo. Então, dependendo da inclinação, acho, do profissional vai se inclinando para um ou outro lado... Bom..., eu me interessei pela saúde pública... Então eu fui me interessando pela sociologia, antropologia social, os aspectos da psicologia socialfuncionamento de grupos e conversando com líderes políticos, conversando 
com professores, conversando com as lideranças da Igreja Católica. Tratando de formar grupos de trabalho e acho que, na formação do médico, faz muito bem este tipo, digamos assim, que vai aprendendo dentro da realidade... vai aprendendo a ser médico na realidade... senão fica aí, encaixotado dentro de seu próprio conhecimento."

J.Y. "Minha trajetória começou, meu interesse por saúde pública, quando era estudante na Faculdade de Medicina, quando eu criei um movimento universitário de desfavelamento. A área de saúde da USP, Católica e a Mackenzie. (....)Entăo, este contato desde a faculdade de medicina com as favelas, que foram uns 6 anos de contato, me despertou pelo sentido social da profissão mas sempre dentro da intersetorialidade.

S.F. "(...)Considero a formação desta Universidade (Faculdade de Medicina de São José do Rio Preto/SP) fundamental, porque, desde do segundo ano atuávamos no campo fazendo um levantamento "epidemiológico". Me lembro muito bem do levantamento epidemiológico da cegueira, que nós fizemos porque o departamento tinha um contato com a saúde pública. Porque, já no segundo ano, estávamos visitando as casas das pessoas e tendo atitude epidemiológica dentro da pesquisa e de entendimento da realidade. Então, acho que isto foi marcante para mim na minha formação. (....)"

Dois entrevistados consideraram que assumir cargos no serviço público de saúde, ou ir para a gestão deste, foi fundamental para despertar o interesse pela saúde pública:

P.N. "(...) tinha uma visão completamente preconceituosa de quem fazia Saúde Publica. Achava que era coisa de quem não queria nada, era essa visão que se tinha. E fui convidado pra ser Secretário da Saúde [Crateús/CE] de uma administração, e lá vi que a questão da saúde era muito, muito mais ampla que 
das salas de emergência, de cirurgia, que vi. E passei a ver que essa turma que fazia Saúde Publica estava bem à frente da gente nessa visão da promoção, da prevenção de saúde. Então foi uma coisa... entrei na Saúde Publica pela porta dos fundos, digamos assim, sem a menor formação disso, por preconceito $e$ terminei, tipo assim, praticamente me apaixonando por essa nova..."

P.C. "Acho que, formalmente, foi a partir de 1985, quando ingressei na Prefeitura do Municipio de São Paulo, como cirurgião-dentista do escolar, através de concurso público. Logo em seguida constatei, já, através de algumas discussões que a gente vinha fazendo anteriormente, dos próprios movimentos que a gente participava, no próprio periodo de universidade... Então, a gente tinha um pouco esta visão, que foi agravada pelo início da prática.

A gente percebe que a prática é muito limitada para inverter o quadro de saúde em que se está envolvido.(...)"

Outra caracteristica interessante, abordada por seis entrevistados, è a atuação docente em universidades, seja no ensino de graduação ou de pósgraduação.

Um deles é consultor técnico da Organização Pan-Americana de Saúde OPAS. Vários fatos ou comentários, apresentados a seguir, irão mostrar que esta Organização tem desempenhado um papel fundamental na difusão da promoção da saúde no Brasil. Os profissionais, como consultores da OPAS, passaram a assumir formalmente o compromisso de implantar, coordenar ou colaborar em grupos de trabalho, na área de promoção da saúde no país.

Discute-se o interesse manifestado, pelos entrevistados, por outras áreas ou campos de conhecimentos. Eles, ao longo da formação profissional, não se restringiram aos estudos dos conteúdos da área biológica. A formação no campo da educação foi a segunda opção de estudo mais citada pelos 
entrevistados. A participação destes profissionais em equipes de trabalho multiprofissional, desde o início da formação profissional, favorece a sua capacitação para o desenvolvimento de açōes de promoção da saúde.

Essa construção de planos de trabalho ou pesquisa envolvendo diferentes áreas de conhecimento ou, até mesmo, diferentes niveis decisórios ou de regulação - governamental, privada (empresas, comércio) e grupos organizados, requer uma qualificação envolvendo várias dimensões. Por exemplo: capacitação comunicacional, de negociação, de articulação, do uso de diversas linguagens, de cooperação entre outras.

Segundo NAIDOO e WILLS (1996): "Há diferentes termos usados para descrever as maneiras das pessoas trabalharem juntas para promover saúde." No estudo em questão, a forma mais citada é o trabalho intersetorial, o qual será discutido mais adiante.

À primeira vista, ao analisar o conjunto das "caracteristicas" relatadas pelos entrevistados, questionou-se se estes poderiam ser denominados de "elite" da academia, "intelectuais" da saúde ou de alguma outra forma. Qualificálos como intelectuais, significaria refletir sobre o que vem a ser um "intelectual' na atualidade.

Segundo BOBBIO (1997) este tema:

"É habitualmente introduzido quando se pretende falar do problema da incidência (ou da falta de incidência) das idéias sobre as condutas dos homens em sociedade, e em especial dos governantes presentes ou futuros, com particular referência a um sujeito especifico ou mais precisamente a um conjunto de sujeitos específicos, considerados como criadores, portadores, 
transmissores de idéias que, desde há um século, são chamados de 'intelectuais'.

(...), são considerados os sujeitos a quem se atribui de fato ou de direito a tarefa especifica de elaborar e transmitir conhecimentos, teorias, doutrinas, ideologias, concepções do mundo ou simples opiniões, que acabam por constituir as idéias ou sistemas de idéias de uma determinada época e de uma determinada sociedade.(...)".

Os pesquisados foram escolhidos, principalmente, pelo fato de serem veiculadores, difusores, "portadores, transmissores" das idéias da promoção da saúde no Brasil, e, nesta lógica, serem considerados, também, criadores deste ideário. Ciente de que a maioria das idéias e conceitos deste campo de estudo tem origem nas Cartas e documentos internacionais, existiria por parte destes entrevistados alguma visão inovadora ou criadora pertinente ao Brasil? Cabe lembrar que, ao se difundir um conceito elou uma prática, muitas vezes incorporam-se certas idéias ou visões pessoais que podem ser inovadoras.

Concordando com a visão de VASCONCELOS (2000), para a qual: “(..) continuamos a adotar, como na virada dos séculos $X I X$ para o $X X$, as questões do além-mar como nossas questões.(...)," fica por compreender como estes trabalhadores ocupando diferentes espaços e "palanques", têm apresentado propostas e idéias concebidas como constituindo a "nova" saúde pública.

Poderia ser considerado intelectual somente aquele que, de alguma maneira, está introduzindo, no Brasil, uma nova compreensão ou dimensão sobre os acordos e discursos internacionais da promoção da saúde, ou seja, aquele que produz e não apenas reproduz? Que tipo de trabalho ou contribuição qualificaria o fazer "intelectual"? 
Faz-se uma tentativa de resposta a esta questão, ainda com base no estudo de BOBBIO (1997), quando este desenvolve uma reflexão sobre quem são os intelectuais

"(...)Diga-se de uma vez por todas que qualquer que seja a extensão, maior ou menor, que se atribua ao conceito de intelectual(como substantivo) - segundo nele se compreendam apenas aqueles que fazem obra de produção artística, literária ou cientifica, ou também aqueles que transmitem o patrimônio cultural adquirido, ou aplicam invenções e descobertas feitas por outros, os criadores ou os comentadores, ou para usar a distinção weberiana, os profetas, aqueles que anunciam a mensagem, ou os sacerdotes, aqueles que transmitem -, as duas categorias (os intelectuais e os que exercem um trabalho intelectual) não coincidem $e$, sobretudo os problemas que a elas dizem respeito, são completamente diversos. Não coincidem porque, se é verdade que um intelectual desenvolve um trabalho náo-manual, é também verdade que nem todos os que desenvolvem trabalho não-manual são intelectuais. O que caracteriza o intelectual não é tanto 0 tipo de trabalho, mas a função: um operário que também desenvolva obra de propaganda sindical ou política pode ser considerado um intelectual, ou pelo menos os problemas éticos e cognoscitivos da sua obra de agitador são os mesmos que caracterizam o papel do intelectual: qual a incidência das idéias sobre as ações?; é lícito distorcer os fatos para alcançar um fim prático?; como sua atividade se coloca no ámbito do poder constituido e do poder que vai se constituir?"

Observando a trajetória dos entrevistados, no setor saúde, nota-se que nem todos assumiram papel de mandatários. Alguns se inserem no poder constituido, como servidores do aparelho do Estado, assumindo cargos de confiança que visam a implementar ou a pôr em prática o ideário estabelecido; outros atuam como críticos, escrevendo ou ministrando aulas que estimulam a 
reflexão ou problematizam as práticas de saúde pública vigentes; há também os prestadores de serviços que também atuam como consultores, em um ir e vir constante, visando a levar à prática o ideário que anunciam.

Ao final, pareceu mais pertinente compreendê-los enquanto intelligentsia da forma definida por REIGOTA (1999):

"Abrange todas as pessoas que estão no movimento de transformações sociais, politicas, culturais e ecológicas, e que tornam conhecidos, seja nos pequenos círculos e grupos seja nos meios de comunicação de massa, o seu comportamento, opiniões e propostas.

A intelligentsia " se caracteriza pela heterogeneidade de seus membros e não tem necessariamente relação com nivel de instrução e classe social. Esse grupo rompe com a tradição de produção, consumo, expressão e acesso às artes, idéias, conhecimentos, comportamentos e participação politica; domina diferentes linguas e linguagens culturais, tem a oportunidade de viajar, encontrar pessoas de diferentes culturas, classes sociais e interesses científicos, artísticos, políticos. Dessa forma, internacionaliza as suas relações profissionais, sociais, familiares e afetivas.

Como cidadãos do mundo, os integrantes desse grupo carregam consigo aspectos especificos do seu meio de origem e incorporam aspectos novos; esses elementos associados, são transformados em experiência singular, cujo percurso aleatório indica alternativas à sociedade global"

Ainda que se aproxime de algumas dimensões do "ser intelectual", o termo intelligentsia foi escolhido por dar conta do ato de refletir e de viajar destes entrevistados: são pessoas com trânsito entre diferentes instituições, entre cidades das diferentes regiões brasileiras e entre países. Os entrevistados reúnem: especialistas, livre-docentes, escritores e administradores. Advogam 
uma nova alternativa para o saber da saúde pública brasileira na atualidade, podendo ser considerados como produtores, circuladores e divulgadores de idéias.

Esta "militância" é reconhecida por muitos deles ao longo da pesquisa. Observando o fragmento de fala abaixo, fica evidente que este referencial, enquanto utopia é visto, também, como instrumento de transformação da realidade.

P.B. “(....)Aí entrei, comecei a me interessar: quer dizer, não é só pela esquerda política! (....)"

\footnotetext{
- Grifo no original.
} 


\subsection{Momento da Vida Profissional que os Difusores se Aproximaram do Conceito de Promoção da Saúde:}

Ao perguntar aos entrevistados como haviam entrado em contato com o conceito de promoção da saúde (pergunta 2) alguns referiram-se a seu relacionamento com a OPAS, como fica evidente a seguir:

E.M. "(...)Quando eu pude entender isso? Foi quando eu pude separar" e me encontrei na OPS com a tarefa de ser delegado a mim, nos final dos anos 80 , mais especialmente, anos 90, a tarefa de implantar aquela coisa que a OPAS tinha recebido o mandato, e não sabia muito bem o que era "cidade saudável", naquele tempo com o nome de "municipio saudável". Mas, de fato, meu encontro com a promoção da saúde vai se dar logo no início do meu trabalho na OPAS, em 87/88, quando, a partir da OPAS, desencadeio um movimento nacional de territorialização, de promoção de saúde, que faço a relação entre serviços de saúde, condições de vida e território.(....)"

D. "Houve alguma leitura, pesquisa algum evento que lhe chamou atenção para esta temática, já com o nome de Promoção de Saúde?

V.P. Acho que a atuação ligada, o trabalho ligado à Organização PanAmericana da Saúde. Eu fui consultor deles e, então, participante freqüente de reuniões, me fez seguir esta linha de maneira quase natural.

\footnotetext{
- O entrevistado evidencia, em uma fala anterior, que há necessidade de separar ou distinguir acesso aos serviços de saúde do conceito de saúde. Para ele, até o presente momento, nos
} 
A.V. "Na própria Bolívia, nós tivemos algumas reuniões, como conseqüência da Carta de Ottawa, para fazer uma análise sobre o que de novo traria isto. Como que se, nós dizemos assim.. "Como que se come? Com talheres?" [Risos]. Então, nós fizemos este tipo de análise para ver que coisas podiam ser aplicadas na Bolivia. E, ... bom, nós contamos, trabalhamos com a OPAS. Fizemos ai algumas coisas relacionadas com Municipios Saudáveis. Mas, 0 conceito mesmo não estava, para nós, muito claro.(....)"

D. "Eu entendo que o seu contato com a promoção foi em 87, na OPAS ?"

J.Y." Como responsabilidade formal, mas eu considero que esta concepção nasceu quando eu trabalhei em favelas. Não com este nome, mas já era promoção."

D. "Com as concepções, os valores?"

J.Y. "É, é. Meu primeiro contato foi quando estava na OPAS, e quando o Dr. Carline*, que era diretor da Organização, propôs a Campinas trabalhar na concepção de município saudável. Então, o diretor pediu que eu acompanhasse a experiência e a divisão de promoção de saúde, que não estava sob a minha direção, participou da proposta. Do desenho..Depois, assisti alguns países, experiências de, como México. Vários paises..."

Portanto, houve influência da Organização Pan-Americana, na qual trabalhavam ou trabalham para acolherem ou assumirem o conceito de promoção da saúde. Isso vem ratificar a visão de MENDES (1996), que ao analisar a presença crescente da promoção da saúde nas políticas de saúde

moldes que está conformado, "o serviço de saúde tem muito pouco a ver com saúde e promoção da saúde."

"Carline de Macedo foi diretor da OPAS em Washington. 
dos paises da América Latina, destaca que, nestes, a Organização PanAmericana, a colocou como "prioridade programática".

Segundo FINKELMAN (1999), representante no Brasil da Organização Pan-Americana e da Organização Mundial de Saúde, em entrevista à Revista de Promoção da Saúde, do Ministério da Saúde: "A promoção da saúde é uma das estratégias centrais da OPAS e da OMS. Nas Américas a promoção da saúde faz parte de nossas prioridades."

A "influência" da Organização Pan-Americana de Saúde (OPAS) na difusão da promoção da saúde no Brasil, através da ascensão dos seus técnicos em cargos estratégicos, foi reconhecida no relato de um dos participantes deste estudo, como se destaca a seguir:

P.C. "Eu acho que, em primeiro lugar, uma ascensão das pessoas que defendem e que trabalham sob este discurso e que defendem estas práticas nos organismos internacionais. Acho que a Organização Mundial da Saúde, sobretudo, tem assumido com mais clareza esta postura. (...) Acho que algumas pessoas dentro destes organismos têm ocupado mais espaço e tal. Financiamento para a pesquisa nesta área, é sempre visto como uma coisa meio torta, enfim, nesta área de política de saúde, de Promoção da Saúde, com dificuldades. Mas, eu diria que eu consigo ver nisto, que estes organismos internacionais que influenciam muito os governos locais, na área da saúde ministros, secretários e tal, eles têm assumido com mais clareza esta postura em relação à Promoção da Saúde. Não é um corpo tão estranho assim, o que faz as mudanças acontecerem com mais receptividade.(....)"

Uma das entrevistadas, mesmo não tendo atuado na OPAS, teve um primeiro contato com o termo promoção da saúde, em um seminário, quando uma consultora dessa instituição proferiu uma conferência com este tema. 
V.L. "Bom, o contexto da minha vida profissional foi curiosa porque... Ah! Quando houve este Seminário [Diagnóstico das Ações de Educação em Saúde no Brasil], nós convidamos uma pessoa da OPAS, que foi Maria Tereza Cerqueira, que tem tido um contato muito estreito com o Brasil e com a FSP/USP. E Maria Tereza fez uma primeira conferéncia... Acho que foi a conferéncia de abertura sobre promoção da saúde. Em função desta presença e deste conteúdo, nós programamos, também, um trabalho de grupo, que houve durante todos os dias do seminário sobre Promoção em Saúde." 


\section{BASES CONCEITUAIS DO MOVIMENTO DA PROMOÇÃO DA SAÚDE}

\subsection{Conceitos Associados à Promoção da Saúde}

Tendo presente a diversidade de significados atribuídos pelos profissionais de saúde ao termo promoção da saúde, buscou-se saber, na quinta questão, como os entrevistados o entendiam ou definiam. Investigou-se, ainda, se para eles, esse termo tem se diferenciado ao longo do tempo.

Caso se pergunte, para diferentes profissionais de saúde, o que significa promoção da saúde, provavelmente, os significados atribuídos a este termo serão tão distintos quanto o número de pesquisados. Ou ainda, caso se afixe um anúncio divulgando um serviço de promoção da saúde, muitos podem até se perguntar que tipo de oferta ou desconto está sendo oferecido nas ações de saúde, pois, em geral, quando se fala em promoção logo vem à idéia a possibilidade de um determinado tipo de produto estar sendo oferecido a preços menores. Às expensas do exagero que possa estar presente nestas afirmações, elas deixam transparecer uma questão: o conceito de promoção da saúde não tem significado univoco no campo da saúde.

Segundo QUIVY e CAMPENHOUDT(1992): "A conceituação é mais do que uma simples definição ou convenção terminológica. É uma construção abstrata que visa a dar conta do real. Para isso não retém todos os aspectos da realidade em questão, mas somente o que exprime o essencial dessa 
realidade, do ponto de vista do investigador. Trata-se, portanto, de uma construção-seleção."

Para o delineamento desse estudo, não se adotou o significado de promoção da saúde somente a partir do conceito proposto, em 1986, na Carta de Ottawa. Mais do que isso, pretendeu-se saber por que, entre os múltiplos significados atribuidos ao conceito de promoção da saúde, apenas um deles foi selecionado, a partir de 1986, como referência de um movimento que, internacionalmente, tem se denominado de a "nova saúde pública" ". Neste estudo buscou-se explicitar contextualmente esse conceito, por compreendê-lo enquanto "invenção social", na medida que é uma construção baseada em relatos de cenários histórico-sociais.(CARVALHO e LIMA 1992)

Ao se iniciar a análise dos depoimentos registrados nas entrevistas, notase que as definições de promoção da saúde tendem a reproduzir a formulação de Ottawa, mas, à medida que se aprofundam questões e se discutem objetivos e expectativas quanto à prática deste conceito, emerge a diversidade de opiniōes discutidas a seguir.

I.C. "(...)Se você voltar uma pouco atrás, você vai ver que os conceitos- chave do que hoje a gente chama de promoção de saúde estão aí há 50, 60 anos Alma Ata era nada mais, nada menos que um precursor de Ottawa e dai por diante. Então, como a gente dá nome novo para coisas, às vezes, que já tivemos a oportunidade de passar, por questionamentos similares, em outros periodos, acho que não vem muito ao caso."

*NUTBEAM (1996) no glossário de promoção da saúde da OMS, considera que a expressão "nova saúde pública faz referencia a uma preocupaçăo pública e profissional pelas repercussర̋es do entomo global [grifo do autor] sobre a saúde." Esta definição é acompanhada por uma nota esclarecedora sobre as bases conceituais da expressão. 
No depoimento acima, confirma-se um ponto de vista da autora desta pesquisa: trata-se da re-emergência do termo promoção da saúde na década de 90 , e não do seu surgimento na saúde pública ocidental. Além disso, para a maioria dos entrevistados, este conceito tem vindo a alterar-se ao longo do tempo

CERQUEIRA (1997), analisando os antecedentes da promoção da saúde, faz uma citação deste conceito, presente nos trabalhos de WINSLOW sobre a saúde pública americana dos anos vinte:

"A promoção em saúde é um esforço da comunidade organizada para atingir políticas que contribuirão para melhorar as condições de saúde da população e os programas educativos para que o individuo melhore sua saúde pessoal, assim como para o desenvolvimento de uma maquinaria social que assegure, a todos, niveis de vida adequados para a manutenção $e$ a melhoria da saúde."

Negando as contradições sociais, o conceito de promoção reflete o papel atribuído à saúde pública da época. O que, então, prevaleceu, foi a ênfase dada à educação em saúde, que se institucionalizaria no Brasil como educação sanitária na década de vinte.

No estudo, extremamente rico, sobre a "evolução histórica da educação em saúde como disciplina de ensino na FSPI USP", CANDEIAS (1988) observa a 'equivalência das expressões 'consciência sanitária' e 'educação higiênica' nos documentos da época." No mesmo estudo, a autora considera que: "Nos termos referidos por alguns, parecia-se sugenir, às vezes, que grandes

\footnotetext{
Segundo CANDEIAS (1984), no estudo sobre a memória histónca da Faculdade de Saúde Pública/USP, "Charles-Edward Amory WINSLOW (1877-1957) foi um dos mais notáveis lideres na área de Saúde Pública nos Estados Unidos e no mundo. Autor de numerosos trabalhos, um dos quais apresenta famosa definiçăo de Saúde Pública."
} 
contigentes da população de nosso pais pudessem tomar decisões, com um pouco de boa vontade', sem explicar que, de fato, os riscos mais importantes não são auto-impostos, porém sociais e ambientais."

Outros estudos (FERREIRA 1991; ORNELLAS 1981; OSHIRO 1988) corroboraram as evidências apontadas por CANDEIAS (1988), mostrando que a educação sanitária, no Brasil, naquela época, visava a aplicação na vida cotidiana dos preceitos médico- higienistas.

TERRIS (1996) realizou um importante trabalho "na tentativa de desenvolver um conceito unificado da promoção em saúde, baseado no estudo de seus antecedentes históricos". Segundo este autor:

"As diferenças do conceito de promoção da saúde surgem fundamentalmente de uma dualidade da teoria da causalidade das enfermidades, isto é, por um lado, as causas especificas das enfermidades e, por outro, as causas gerais.(..) Trata-se de um conceito muito amplo sobre o qual distintos grupos têm tendido a limitar-se a um ou outro aspecto da formulação total".

De acordo com esse autor, o termo promoção da saúde foi utilizado pela primeira vez em 1945, quando SIGERIST definiu as quatro tarefas essenciais da medicina: promoção da saúde, prevenção da enfermidade, restabelecimento dos enfermos e reabilitação. TERRIS refere-se ao historiador médico, acima citado, para quem a promoção em saúde definia-se em termos dos fatores gerais que levam à enfermidade: "A saúde se promove proporcionando condições de vida decentes, boas condições de trabalho, educação, cultura física e formas de lazer e descanso', para os quais pediu o esforço coordenado dos políticos, dos setores trabalhista e industrial, dos educadores e dos médicos." 
TERRIS mostra que os estudiosos da epidemiologia e da medicina social "tanto se preocupavam com as causas gerais, as condições de vida, quanto com as causas especificas, os 'fatores nocivos' do entorno físico e social que determinam o estado de saúde de um grupo ou classe social". Acrescenta que, com o desenvolvimento da epidemiologia das doenças não infecciosas, surgem os denominados fatores do "estilo de vida, no sentido de que as pessoas podem tomar decisões que influem em sua exposição a estes agentes."

A relação entre condições de vida, qualidade de vida e saúde é retomada na discussão das "modernas concepções" de promoção da saúde. (GOLDBAUM 2000) Um dos entrevistados, concorda com a afirmação de TERRIS, de que as proposições da promoção da saúde, na atualidade, decorrem de uma mudança de visão do que é saúde, como se evidencia no trecho abaixo:

E.M. "Pra mim hoje (promoção da saúde) seria uma prática sanitária que se fundamenta a partir de uma concepção de processo de saúde-doença inovadora, ou seja, da positividade da saúde e de um paradigma que eu chamo de paradigma de produção social de saúde. A saúde é algo que está estocado em um determinado momento, em uma determinada sociedade, e pode acumular e desacumular pela ação sobre os determinantes. Então, são três categorias fundamentais com as quais eu trabalho: a concepção de processo de saúde/doença, o paradigma sanitário e a prática sanitária. Então, na visão convencional nós temos uma concepção negativa como a auséncia de doença, - paradigma flexneriano e a prática da atenção à saúde. Nesta concepção inovadora, nesta visão mais ampla, você tem a concepção positiva, saúde como produto social, o paradigma da produção social da saúde, e a prática sanitária da promoção saúde. Para operacionalizar isto, a estratégia de 
operacionalização disso, eu trabalho com a proposta de cidade saudável. Porque para operacionalizar campo de serviço de saúde, é outra história."

Esta nova prática se fundamenta numa concepção de saúde enquanto "um recurso aplicável à vida cotidiana e não como o objetivo desta vida; é um conceito positivo que se apoia nos recursos sociais e pessoais e, também, na capacidade física" (KICKBUSCH 1996). À medida que se estuda o conceito de saúde esta deixa de ser, tão somente, uma tarefa médica, procurando não isolar o individuo do contexto em que vive.

Segundo GENTILE (2001): “O conceito de estado positivo de saúde, se refere, no geral, à qualidade de vida e ao potencial da condição humana. (...) inclui a energia para viver, a auto-realização e a criatividade. Um estado positivo de saúde está mais relacionado com o progresso pessoal do que com a simples resolução de problemas, transcende claramente a preocupação tradicional da medicina por presenvar e restaurar a saúde."

Além dos aspectos sociais, este conceito ampliado de saúde inclui aspectos emocionais. Agrega aspectos objetivos e subjetivos, dimensões coletivas e individuais. Não constitui objetivo deste estudo, contudo, discutir se esta concepção de saúde, que fundamenta a promoção da saúde, caracteriza ou não uma mudança paradigmática na saúde pública ocidental. Alguns autores têm tratado desta questão (RAWSON 1992; CANDEIAS 1998; FERRAZ 1998 e ROBERTSON 1998). Retoma-se aqui a busca dos significados atribuídos à promoção da saúde, contextualizando os marcos desta temática ao longo do tempo.

A partir de 1945, segundo TERRIS (1996), o significado de promoção da saúde, também, passou a ser associado a medidas preventivas ligadas aos ambientes físicos e estilos de vida. 
No trabalho de TERRIS, o documento de interesse para a discussão do conceito de promoção da saúde é o Informe Lalonde. No presente estudo, considera-se que, no caso do Brasil, além de se abordar esse Informe, outro esquema de referência deve ser pensado. É o conceito de promoção da saúde presente nos estudos de LEAVELL e CLARK (CHAVES 1977).

A formação dos profissionais da saúde pública brasileira foi influenciada pelas escolas norte-americanas de saúde pública (CANDEIAS 1984; IYDA 1994). Um modelo explicativo, oriundo de lá, teve ampla difusão no campo da saúde, o da história natural da doença. Segundo este, toda a doença tem sua maneira própria de evoluir, quando abandonada a seu próprio curso. Propunhase que os profissionais atuassem de forma a criar barreiras em distintas etapas do ciclo evolutivo da doença. Segundo LEAVELL e CLARK, a primeira etapa, ou primeiro nivel de prevenção, era o de promoção da saúde. CHAVES (1977) afirma que:

"Neste nivel procuramos criar as condições mais favoráveis possiveis para que um individuo esteja em condições de resistir ao ataque de uma doença ou grupo de doenças. Neste nivel, nossa atuação é inespecifica. Procuramos aumentar a resistência do individuo e colocá-lo num ambiente favorável à saúde. Medidas como nutrição adequada, exercícios ao ar livre, vivenda confortável e limpa, roupa adequada ao clima, trabalho estimulante sob o ponto de vista mental, recreação, vida familiar, não constituem método especifico de prevenção de doenças, mas ajudam a tornar o ambiente mais desfavorável à maioria das doenças."

Um dos entrevistados menciona o conceito de promoção da saúde,segundo LEAVELL e CLARK. Além disso, diz que esta visão continua 
fazendo parte da formação dos recursos humanos da saúde até o presente momento.

M.A. "Eu não sei quando eu comecei a chamar isso de Promoção, chamava de prevenção de doença. Talvez mais na CASSI, mais com o movimento de cidade saudável, estrutura um pouco... Apesar de que sempre que a gente dá aula e fala do Modelo de LEAVELL e CLARK fala sobre prevenção primária, secundária, terciária. A prevenção primária tem promoção de saúde e proteção especifica. Então a promoção sempre foi uma coisa que talvez seja fácil para as pessoas que não estão doentes, uma coisa de educação e saúde, talvez já misturada com promoção da saúde."

Quando se pergunta aos profissionais da saúde o que é promoção da saúde, freqüentemente eles se referem a este significado. $O$ fato de não se mencionar esta visão de promoção da saúde, nas discussões atuais, tem causado estranheza. Mesmo que se considere que esta visão está mais atrelada à noção de doença que a de saúde, não se pode ignorar que ela ainda permeia as mentes das pessoas. Nem que seja para argumentar o porquê dela não ser incluída na "nova prática" de saúde, sua discussão deve ser retomada. Considera-se, no presente projeto, que a exclusão da visão de LEAVELL e CLARK, na atualidade, responde a alguns interesses, que merecem ser investigados.

Muitas das medidas exemplificadas na citação de LEAVELL e CLARK tratam de modos de vida, muito embora jamais os tenham designado de "estilos de vida". Estes fazem parte do elenco dos determinantes da saúde presentes no conceito de Campo de Saúde, que será apresentado mais adiante.

BUSS (2000), comentando o sentido do termo promoção da saúde, segundo LEAVELL e CLARK, considera que: "trata-se, portanto, de um enfoque 
da promoção da saúde centrado no individuo, com uma projeção para a familia ou grupos, dentro de certos limites." Promoção da saúde, aqui, refere-se basicamente aos cuidados à saúde, quando o processo da doença se restringe às interações entre hospedeiro, agente e ambiente, sem alterações patogênicas.

Outra conseqüência desta interpretação, devida a LEAVELL e CLARK,é que promoção da saúde se confunde ou está associada ao conceito de prevenção de doenças. Esta associação do conceito de promoção ao de prevenção é feita por um dos entrevistados, como se ressalta a seguir:

V.P. "Então, surge esta questão da promoção da saúde como uma idéia. Ela surge, não como uma mania, mas como uma idéia-força muito grande e que leva, em geral, as pessoas, a falarem que a promoção, que a prevenção (o termo prevenção volta muito forte em toda sociedade, fora da saúde com muita força) em função desse movimento [da promoção da saúde]. Entăo, acaba a promoção da saúde desenvolvendo aquele conceito básico de prevenção que foi sempre necessário. O que a gente não conseguia fazer com a linguagem, com o linguajar antigo, acabamos fazendo agora. E, esta mudança é muito boa, muito positiva."

V.P. "Eu acho que a promoção da saúde significa, basicamente, uma inversão de fatores, uma prioridade forte e definitiva para as ações de prevenção e organização geral dos sistemas, de educação. Inclusive, utilizando os termos mais antigos que eram da área. Mas ela significa um novo enfoque, uma inversão forte de maneira de ver a saúde das pessoas, aquilo que estava nos conceitos básicos de saúde, de que ela envolve uma série de setores e fatores e não só a saúde, ou o tratamento da saúde em si. Começa a ganhar espaço com a promoção da saúde, na verdade, você começa a ver indivíduos a partir 
da estratégia de manutenção da saúde e não só da cura da doença. E, esta foi a mudança fundamental."

No depoimento acima o conceito de promoção também é concebido como idéia-força, que tem a função de estimular as pessoas, até mesmo fora do setor saúde, a pensarem, a buscarem, a desenvolverem ações para a prevenção dos problemas.

$\mathrm{Na}$ visão deste entrevistado, evidencia-se ainda que o conceito de promoção se fundamenta em uma compreensão de saúde que não é nova, uma vez que já se encontrava nos conceitos básicos de saúde. Com a mudança do termo, tem contribuido para mostrar a necessidade de se atuar em função do tratamento, mas, também, em função da manutenção da saúde.

Considerando a promoção da saúde e a prevenção de enfermidades como processos complementares, CASTILLO (1993), no Manual de Promoção da Saúde, dirigido a estudantes de enfermagem, apresenta um quadro para diferenciar os dois conceitos. 
Quadro 3 - Demonstrativo das diferenças dos conceitos de Promoção da Saúde e Prevenção de Doenças

\begin{tabular}{|c|c|}
\hline Promoçåo da Saúde & Prevenção de Doenças \\
\hline $\begin{array}{l}\text { 1. Ações gerais não especificas de } \\
\text { enfermidades ou problemas. }\end{array}$ & $\begin{array}{l}\text { 1. Ações especificas para problemas } \\
\text { de saúde ou doenças especificas. }\end{array}$ \\
\hline 2. Conduta de aproximação. & 2. Conduta de afastamento. \\
\hline $\begin{array}{l}\text { 3. Busca expandir o potencial } \\
\text { positivo da saúde. }\end{array}$ & $\begin{array}{l}\text { 3. Busca evitar a ocorrência de enfer } \\
\text { midades e a perda do bem estar. }\end{array}$ \\
\hline $\begin{array}{l}\text { 4. Ajudar, alentar a que exista ou } \\
\text { floresça o bem estar. }\end{array}$ & 4. Evitar que ocorra a "enfermidade". \\
\hline
\end{tabular}

Fonte: Castillo, M.M.L. et al Manual de Promoción de la salud dirigido a estudiantes de enfermaria. Universidad Autonoma de Nuevo Leon. Monterrey, México. Facultad de Enfermaria, 1993.

Após diferenciar o conceito de promoção do de prevenção, retoma-se os principais marcos da trajetória da construção do conceito de promoção da saúde no campo da saúde pública ocidental.

Em 1974, o então Ministro da Saúde e Bem-Estar do Canadá, Marc LALONDE, publicou o relatório A New Perspective on the Health of Canadians. Para HANCOCK et al (1998), neste Relatório ou Informe, "pela primeira vez, um governante maior reconhece publicamente que a medicina e o sistema de saúde desempenham somente um pequeno papel na determinação do status de saúde. Foi, também, o primeiro documento a sugerir a health promotion' como uma estratégia-chave para melhorar a saúde."

Coerente com sua afirmação inicial de que a diferenciação do conceito de promoção da saúde advém das diferentes formas explicativas do processo saúde-doença, TERRIS comenta que como o Informe Lalonde promove uma ruptura na forma como até então vinha se intervindo na saúde pública. Observa TERRIS: 
"O Informe Lalonde foi a primeira declaração teórica da saúde pública, oriunda dos descobrimentos feitos no campo da epidemiologia das enfermidades não infecciosas. Da estreita perspectiva tradicional de que 'a arte ou ciência da medicina tem sido o manancial de onde tem surgido todos os progressos da saúde' se passou a um Conceito de Campo da Saúde. mais amplo, que consta de quatro elementos determinantes: biologia humana, meio ambiente, estilo de vida e organização da atenção sanitária." LALONDE esclarece, no Relatório, que "estes quatro elementos foram identificados através do exame das causas e fatores subjacentes à doença e à morte, no Canadá, e através da análise do papel que estes elementos desempenham ao afetar o nivel de saúde no Canadá."

Ao apresentar as limitações da visão tradicional do setor saúde - "que faz com que na maioria das mentes o campo da saúde e sistema de cuidado médico sejam sinónimos" - se evidencia, também, enquanto preocupação deste documento, os altos custos da visão de saúde centrada no médico, que trata da doença através do cuidado médico, cuidado hospitalar, teste laboratoriais e prescrição de medicamentos. LALONDE enfatiza que individuo e coletividade, paciente, médico, cientista e governo devem estar cientes que, todos eles, desempenham um papel determinado e influenciam o nivel de saúde.

Com base no Conceito de Campo de Saúde, são apresentadas, neste relatório, cinco estratégias: estratégia de promoção da saúde, estratégia reguladora, estratégia de investigação/pesquisa, estratégia de eficiência do sistema de saúde e , finalmente, a estratégia de estabelecimento de objetivos. A estratégia de promoção da saúde "objetivou informar, influenciar e assistir

\footnotetext{
Há controvérsias quanto à autoria deste conceito. CARVALHO (1996) considera que o conceito de Campo de Saúde foi proposto por LAFRAMBOISE, H. na seguinte publicação: Health policy: breaking the problem down in more manageable segments. Canadian Medical Association Joumal 1973; 108:388-93. Já, outros autores (CANDEIAS 1998; BUNTON 1992; TERRIS1996) conferem a autoria a LALONDE, indicando como referência o seu Informe.
} 
tanto individuos quanto organizações, de modo que eles assumam maior responsabilidade e sejam mais ativos em questões que afetam sua saúde mental e fisica." (LALONDE 1974)

Após duas décadas do lançamento do Informe, LALONDE (1996), ao discutir seu modelo, afirma que o componente organização da atenção tem menor relevância que os demais fatores do Campo da Saúde.

HANCOCK (1998) aponta três resultados do New Perspective on the Health of Canadians:

"- a criação, em 1978, do Diretório Federal de Promoção da Saúde dentro do Departamento Nacional de Saúde e Bem-estar;

- rápido crescimento de programas enfocando estilo de vida, apresentando marketing social e campanhas de educação em saúde;

- um refinamento das práticas de promoção da saúde em comunidades e na zona rural em todo o país."

Para CANDEIAS (1998):

"A principal mensagem da comunicação do Ministro Lalonde era a de que a introdução de mudanças no ambiente (enfoque estruturalista) e no comportamento das pessoas (enfoque do estilo de vida) poderia reduzir significativamente a morbidade e a morte prematura. Como resultado desse Relatório, o governo canadense alterou a ênfase de sua política de ação social, afastando-a da prevenção e tratamento de doenças, de acordo com as premissas da fase anterior da saúde pública, em favor da promoção em saúde."

BUNTON e MACDONALD (1992) consideram que já estava "implícita na estratégia de Saúde Para Todos no Ano 2000 (Conferência da OMS de 1977) a 
nova visão de promoção da saúde combinando os enfoques de estilo de vida e estruturalista."

Para BUSS (2000) as deliberações da Conferência de Alma-Ata ou 1 Conferència Internacional sobre Cuidados Primários da Saúde, realizada em 1978, reforçaram os pressupostos dos novos significados atribuidos à promoção da saúde. Destaca, esse autor, os aspectos que considera importantes e que não são tão divulgados: "a reafirmação da saúde como direito humano fundamental; que as desigualdades são inaceitáveis; que os governos têm responsabilidade pela saúde dos cidadãos e que a população tem o direito de participar das decisões no campo da saúde."

No depoimento abaixo, um dos entrevistados confirma a leitura desses autores:

I.C. "Eu conversando com uma pessoa que esteve em Alma Ata, ouvi: 'Olha, não criaram nada de novo. É tudo que a gente disse em Alma Ata', abriu até os capitulos. 'Olha está aqui, é isso que é promoção da saúde. 'Então, conversava com um pessoal mais antigo ainda, de mais tempo: 'pois é, era isso que a gente fazia'. Otimo, perfeito!(...)

Segundo KICKBUSCH (1996), até 1981, o Canadá era o único pais que contava com uma Direção Geral de Promoção da Saúde. Data de 1984 o início do Programa de Promoção da Saúde da Oficina Regional da OMS (Organização Mundial de Saúde) para a Europa. A autora cita um Documento de discussão sobre o conceito e os principios da promoção da saúde desta Oficina, que define a "promoção da saúde como o processo que permite às pessoas adquirir maior controle sobre sua própria saúde e, ao mesmo tempo, melhorar essa saúde." 
Para EPP (1996): "Esta visão de saúde reconhece a liberdade de escolha e enfatiza o papel do indivíduo e comunidades na definição do que a saúde significa para elas." Há que se pensar que a liberdade de escolha não é algo que se tem ou se recebe como um "presente dos céus". É fruto de uma maior ou menor concentração de poder e de conquistas individuais e coletivas, que fazem que uma sociedade seja mais ou menos democrática. Isto porque a vida humana $e$ as prerrogativas a ela conferida são influenciadas pelas circunstâncias, pelo processo histórico, pela estrutura sócio-econômica, crenças, costumes e sentimentos.

Agrega-se ao conceito de saúde a compreensão deste como constituindo um recurso, um instrumento com o qual as pessoas devem contar no seu dia a dia. Segundo EGYDIO DE CARVALHO (1998), a "saúde não é um resultado, mas um dos princípios das políticas públicas." Neste sentido, a saúde enquanto uma dimensão da qualidade de vida deveria orientar a definição, as escolhas dos investimentos $e$ as ações das diferentes áreas relacionadas ao desenvolvimento social e econômico.

KICKBUSCH apresenta os cinco princípios fundamentais da promoção da saúde expressos no Documento:

"1. afeta a população em seu conjunto no contexto de sua vida diária e não se centra nas pessoas que correm o risco de sofrer determinadas enfermidades;

2. pretende influir nos determinantes ou causas da saúde;

3. combina métodos ou enfoques distintos porém complementares.;

4. orienta especificamente no sentido de conseguir a participação concreta e específica da população; 
5. profissionais da saúde (particularmente no campo da atenção primária) devem desempenhar um papel de grande importância na defesa $e$ facilitação da promoção da saúde."

Observa-se, nestes principios, a incorporação do conceito de atenção primária, foco da Declaração de Alma-Ata, realizada na então União Soviética. Outro principio da Declaração presente: é o da participação comunitária. Algo que fica por se esclarecer é o que se entende por participação concreta e especifica da população? (ROBERTSON e MINKLER 1994)

Segundo FERREIRA e BUSS (2001):

“Em 1984, sob a liderança do ministro Jake Epp, em uma conferência canadense denominada 'Além do Cuidado da Saúde', com participação do Escritório Europeu da Organização Mundial da Saúde (EURO/OMS), dois novos conceitos foram introduzidos: o de política pública saudável e o de cidade ou comunidade saudável. Admitiu-se, com isso, a influência na situação de saúde a partir de decisões políticas externas ao setor saúde, e, com a idéia de 'cidade saudável, avançou-se no conceito de 'empoderamento' e participação social, promovendo saúde através da descentralização do poder às comunidades locais. A estratégia de atenção primária de saúde (Alma-Ata) com o enfoque multissetorial, o envolvimento comunitário e os componentes da tecnologia apropriada, reforçaram a promoção na direção da saúde ambiental."

Foi criado um grupo internacional de estudo para responder a seguinte questão: "Poderia aplicar-se esse enfoque (da Promoção da Saúde) nos países em desenvolvimento ou seria este somente adequado para os paises industrializados?" O grupo reuniu-se em Copenhague em 1985. KICKBUSCH relata que seus membros consideraram que a promoção da saúde poderia 
"aplicar-se a paises muito diferentes dos industrializados", com o detalhe de que "a porta de entrada seria diferente."

“(..) No mundo em desenvolvimento, onde os sistemas de atenção sanitária não estão ainda tão fossilizados como no velho mundo, a promoção da saúde poderia formar parte, desde o principio, das políticas de saúde e da atenção primária de saúde. Pelo contrário, no velho mundo poderia supor um desafio aos sistemas estabelecidos de tratamento das enfermidades e de assistência médica, dado o grande papel que desempenham nela a prevenção e as medidas de saúde pública. Assim, as estratégias e atores da promoção em saúde deveriam ser muito distintas nas diferentes partes do mundo, porém a filosofia básica seria similar."

Como resultado da reunião de Copenhague, "nasceu a idéia da primeira conferéncia internacional importante sobre promoção da saúde, que deveria celebrar-se em Ottawa, Canadá, em novembro de 1986, com o patrocinio conjunto do Ministério da Saúde e Bem-Estar do Canadá, a OMS e a Associação Canadense de Saúde Pública." (KICKBUSCH 1996)

Desta conferència resultou uma Carta onde se conceitua promoção da saúde como: “(...) o processo de capacitação da comunidade na melhoria da sua qualidade de vida e saúde, incluindo a maior participação no controle deste processo."(OMS 1986)

A idéia de processo pode remeter à noção de que isto é algo dinâmico e, como tal, tem começo, mas não tem fim, ocorrendo ao longo de toda a vida. Comparado este conceito ao que foi apresentado anteriormente no estudo de $\mathrm{KICKBUSCH}$, nota-se que, em Ottawa, se endereça a ação à comunidade e não às pessoas individualmente. Aceitar a comunidade, como porta-voz fundamental em matéria de saúde, constitui um dos muitos compromissos dos 
participantes da Conferência de Ottawa. São introduzidos, também, os conceitos de qualidade de vida e participação.

Para FERRAZ (1998): "Se, por um lado, o relatório Lalonde significou um avanço em termos do questionamento das limitações do impacto da assistência médica sobre as condições de saúde, a Carta de Ottawa*, por outro, consagrou um novo marco conceitual no qual a promoção da saúde considera que a saúde 'vai mais além dos estilos de vida'. Desde então observa-se que novas estratégias e intervenções vêm sendo mundialmente experimentadas."

No presente estudo, a maioria dos entrevistados ao definir o que entendia por promoção da saúde, reporta-se ao conceito presente na Carta de Ottawa. Alguns exemplos:

P.C. "Se eu não estou equivocado, porque eu tenho uma memória péssima para frases e estas coisas todas, mas o conceito chave que sai de Ottawa, sai da Carta de Ottawa é de que é todo apoio à pessoa para que ele auto-promova sua saúde, basicamente isso. Claro que, depois da Carta, este conceito é muito mais que isto, mas, este conceito é muito difundido. É como um conceito chave da reunião de Ottawa, que determinou os parâmetros mundiais para a discussão da promoção de saúde. É o documento referéncia."

J.Y. "Bom, a definição está na Declaração de Ottawa, do Canadá.(...)"

Mesmo se referindo ao conceito de promoção de Ottawa, muitos entrevistados fazem uma leitura crítica deste ou acrescentam outras dimensões a ele, conforme pode ser observado a seguir.

\footnotetext{
" Grifo no original.
} 
S.F. "Não, eu acho que a Promoção de Saúde, que dizer, você tem, nos termos gerais, vocé tem a Carta de Ottawa que estabelece seus parâmetros. Mas, eu acho que em cada país você vai ter uma definição diferente de acordo com o seu contexto e suas necessidades. No Brasil, por exemplo, se você andar na Amazónia, a Promoção da Saúde vai ser uma coisa, no Centro-Oeste outra, no Sudeste outra. Em São Paulo, viver na floresta é uma coisa, viver na cidade de São Paulo é outra coisa. Então eu acho que ai precisa se ter uma abertura porque a Promoção da Saúde vive em função de cada comunidade, de cada cultura. Eu acho que no Brasil, agora, depois de 500 anos, é que nós estamos tomando consciência de que nós somos um país multicultural. E lidar com essa riqueza e construir uma nova lógica.(...)"

A.V. "Eu não vou compartilhar com você, não se diminui a noção que se diz na Carta de Ottawa, mas de 'desiderato' vou Ihe dar meu próprio conceito. Eu acho que a promoção da saúde é uma estratégia de saúde pública, que procura no conceito de saúde incorporar os elementos de participação, de intersetorialidade, do enfoque do indicador positivo, no próprio 'que fazer' na saúde pública. Mas acho que ainda este conceito próprio, de saúde pública, da promoção da saúde não está muito consolidado, sedimentado. Nós ainda estamos tendo um discurso que não chegou, digamos, a fazer parte do discurso cotidiano. Por conseqüência de que é uma coisa na qual existem mais grupos académicos que estão discutindo os aspectos da Promoção Saúde do que no nivel dos serviços de saúde, por isso que existe este grande discurso académico que não esta sendo bem... Como se diz? ...."

\section{Sendo operacionalizado?}

A.V. "É, sendo operacionalizado ... Exatamente, acho que ainda falta isso... que temos que trabalhar nos conceitos de tal maneira que a promoção da saúde, que nem hoje se faz com epidemiologia, saúde pública, materno infantil etc. 
Seja como parte do instrumental e seja como parte do cotidiano tanto da mentalidade da saúde pública quanto do fazer da saúde pública. Ainda não conseguimos falar de Promoção da Saúde nos Serviços de Saúde. É diferente de falar Promoção da Saúde na universidade.

J.Y. "Bom, a definição está na Declaração de Ottawa, do Canadá. Mas, eu entendo a promoção de saúde como aquele conceito que se preocupa com a qualidade de vida da população, em que os diversos componentes são fundamentais: a saúde, a educação, transporte, na segurança. Para garantir, ser coerente com este conceito, a participação intersetorial é fundamental.

Para KELLEHER (1996), esse "documento representa uma sintese de enfoques e idéias provenientes de um espectro de disciplinas e ele coloca, pela primeira vez, parámetros dentro dos quais um corpo de teoria e prática póde ser estabelecido.".

Consonantes com esta visão, BUNTON e MACDONALD (1992) afirmam que "a promoção da saúde tem emergido nos anos 90 como um conceito unificado que tem trazido junto um número de separados, e até mesmo dispares, campos de estudo debaixo de um guarda-chuva."

Este conceito amplo, de efeito "guarda-chuva", apresentado na Carta de Ottawa, tem sido citado nas introduções, discussões e referências dos trabalhos, que se identificam como fazendo parte do "movimento" da nova saúde pública. Isto ficou evidente nos depoimentos acima. Mas, os entrevistados ao definirem promoção de saúde não se restringem ao conceito proposto em Ottawa, ainda o associam a vários outros conceitos.

Na literatura pesquisada foi encontrada referência ao termo Promoçāo da Saúde desde a década de 1920, sendo a este atribuídos diferentes conceitos que variaram ao longo do tempo. Após se evidenciar, neste tópico, que o 
conceito de promoção da saúde foi apresentado em outras épocas, com significados que nem sempre convergiram ou convergem para o que se identificou durante a reunião de Ottawa, pode-se compreender porque neste estudo se considera que o termo de promoção da saúde está re-emergindo, fundamentado, contudo, em outros conceitos e modalidades de ação.

Há, portanto, uma diversidade de significados expostos pelos entrevistados: visão do senso comum; objeto e finalidade da saúde pública da década de vinte; medidas preventivas sobre os ambientes físicos e estilos de vida; visão de LEAVELL e CLARK; conceito da Carta de Ottawa. 


\subsection{Documentos das Conferências}

Ao perguntar-se se alguma leitura havia contribuido para que eles se interessassem pela promoção da saúde (questão 3), a maioria dos entrevistados referiu-se às declarações ou relatórios das Conferências Internacionais de Promoção da Saúde. Confirmou-se, assim, uma tendência já comentada em outros estudos (GENTILE 2001; MINISTÉRIO DA SAÚDE 2001; BUSS 2000; ROCHA 1997): estes documentos têm constituído a base conceitual do movimento da promoção da saúde.

D. Houve alguma leitura, pesquisa ou evento que contribuiu, influenciou ou despertou o seu interesse para a promoção da saúde?

V.L. "Eu procurei ler, cada vez mais, sobre Promoção de Saúde. O texto, os relatórios das Conferências Internacionais. Todas desde Ottawa, Adelaide, Sundsvall, Jacarta...."

E.M. "(...) O impacto da Carta de Ottawa, que conheci bem. Embora não seja muito conhecida aqui no Brasil, teve um impacto muito grande no meu pensamento. Eu tive contato com a Carta, exatamente por ai, no final dos anos 80 ...88/90. Por aí, não sei."

Os participantes deste estudo referendam e, até mesmo, emitem opiniões que, muitas vezes, reproduzem os textos das Conferências. Porém, pôde se perceber que já apresentam criticas e se posicionam em termos das 
especificidades ou particularidades da utilização deste conjunto de recomendaçōes na realidade brasileira.

Os entrevistados foram informados que o interesse principal desta pesquisa prendia-se à opinião deles e não apenas ao discurso oficial dos documentos da área. Exemplifica-se com os dois depoimentos abaixo.

I.C. "É dificil a gente discutir promoção sem um contexto. A não ser que a gente fique discutindo aqui academicamente promoção de saúde é isso, é aquilo, é aquilo... Não tem muito sentido e também não estou muito a fim de discutir por esse ángulo. A gente pode pensar em promoção mas não tem muito sentido sem um contexto especifico. Eu te recomendo, se você não viu, todas as cartas da promoção que dizem lá.... 10 entrevistado informa não ter interesse em discutir conceitualmente o termo. Nesse e em vánios outros momentos da entrevista, enfatiza que o seu interesse é pela aplicabilidade ou prática da promoção, no cotidiano dos serviços.]"

D. Eu tenho estudado as cartas e o que mais importa não é a definição conceitual das cartas, mas a sua visão. Como é que cada um vai operacionalizando o conceito que tem seus principios já estabelecidos em várias cartas. (...)"

D. O que tem mais valor neste trabalho, nesse estudo que estou fazendo, é seu conceito, sua visão mais amadurecida por ter que trabalhar com este conceito, operacionalizando-o e divulgando-o ..... a sua visão pessoal. O sr. considera que houve mudanças na esséncia do conceito, desde quando o Sr. iniciou as suas primeiras aproximações até o momento?

A.V. "Ah! Mudou sim. Como estava dizendo .... sobre os meus primeiros escritos, dos quais sinto vergonha porque são incompletos e sofrem de pouca 
sustentação teórica. (risos) Mas, é parte da vida acho. Nunca vamos fazer uma coisa perfeita, sempre poderemos melhorar. Este melhoramento vai "em linha" com a experiência, com os relacionamentos sociais que a pessoa tem, com a aproximação da pessoa com as leituras teóricas... A mesma evolução das coisas.(...)" 


\subsection{1- Carta de Ottawa, 1986}

Na Carta de Ottawa, em 1986, explicita-se o compromisso individual e coletivo que todos devem ter para se atingir o objetivo comum de "Saúde Para Todos Até o Ano 2.000." Para o cumprimento deste objetivo: "A promoção em saúde exige a ação coordenada de todos os setores envolvidos: os governos, os setores sanitários e outros setores sociais e econômicos, as organizações filantrópicas, as autoridades locais, a indústria e os meios de comunicação."

Nessa visão, o conjunto de políticas públicas, numa ação intersetorial se constituiria em um centro de produção social da saúde. Na introdução deste documento se recordam os compromissos com a "Declaração de Alma-Ata", com as diretrizes da OMS sobre "Saúde Para Todos", assim como com as discussões da Assembléia Mundial da Saúde sobre as ações intersetoriais necessárias para o setor

Mesmo proclamando que a promoção da saúde requer a ação coordenada de todos os setores, assinala-se a "responsabilidade maior do setor saúde." Essa Carta de Intenções ou de Compromissos é considerada como "uma resposta às crescentes expectativas por uma nova saúde pública, movimento que vem ocorrendo em todo o mundo." Ali se apresentam os "novos temas" que deveriam atrair o foco da atenção da saúde pública: "poluição, trabalho perigoso, questões de habitação e dos assentamentos rurais. (..)A política de promoção da saúde tem de combinar enfoques diversos, se bem que complementares, entre os quais figuram a legislação, as medidas fiscais, 0 sistema tributário e as mudanças organizacionais." (MINISTÉRIO DA SAÚDE 1996) 
Nesta Carta apresenta-se a idéia de novos conceitos relacionados a formas de vida saudáveis e estilos de vida, os quais prevalecem na implementação das medidas recomendadas pelo Informe Lalonde. (FERRAZ 1998). Incluíram-se como pré-requisitos essenciais à saúde: paz, habitação, educação, alimentação, renda, eco-sistema estável, recursos sustentáveis, justiça social, eqüidade.

Essa visão de saúde, resultado das condições concretas de vida, aproxima-se do conceito de saúde formalizado na VIII Conferência Nacional de Saúde, realizada em Brasilia, também, no ano de 1986. (WESTPHAL 1998a). Teve, portanto, um significativo impacto.

P.B. “A Carta de Ottawa, para mim, é o panfleto, a carta de princípios da promoção de saúde dos industrializados. No Brasil, não vou falar da América Latina, temos nossa "Carta da Promoção", sem esse nome, que é a VIII Conferéncia Nacional de Saúde e seu relatório final. Ela coloca a determinação múltipla do processo de saúde-doença; a idéia da intersetorialidade na resposta; a participação social. Só que ela ainda tem o modelo, quer dizer, o modelo que ela propõe é ainda um modelo do sistema de saúde. Quer dizer, não consegue construir as outras pontes..."

Como se observa no depoimento acima, alguns entrevistados fazem uma análise da afinidade conceitual e de temporalidade (em termos do periodo de realização) destas conferências, fato que será discutido no tópico sobre os elementos que favoreceram a entrada da promoção da saúde no Brasil.

Os elementos ou as estratégias básicas apontadas pela Carta de Ottawa, elaboração e implementação de políticas públicas saudáveis, criação de ambientes favoráveis à saúde, ação comunitária, desenvolvimento de 
habilidades e reorientação dos serviços de saúde, são considerados em termos de sua interdependência.

No depoimento abaixo, nota-se que as cinco estratégias ou campos de ação apresentados em Ottawa, transparecem na definição de promoção da saúde.

J.Y. "É fundamental, no conceito, considerar as politicas públicas, que são diferentes de politicas governamentais. A politica pública envolve o governo e a sociedade civil organizada. Outro conceito muito importante é o que se refere à política pública e à política governamental. E, também, os estilos de vida. $O$ estilo de vida tem muita influência na qualidade de vida. Agora, o conceito promoção de saúde chama atenção, também, para a saúde ambiental e meio ambiente, como um entorno importante. Em relação, também, a mudanças de atitude e prática. No setor saúde, a Carta de Ottawa especifica um princípio que eu sinto ser pouco trabalhado no serviço de saúde. É um conceito que a promoção de saúde tem explicito, a reorientação dos serviços de saúde. Os serviços de saúde devem ser reorientados através do conceito de promoção de saúde, o que significa como trabalhar o intersetorial, a participação social mais consciente e o conceito de qualidade de vida. É pouco trabalhada a reorientação do modelo de atenção em direção ao conceito de promoção de saúde."

As premissas da proposta da reorientação dos serviços, no texto da Carta, fundamentam-se em très itens:

"O papel do setor saúde deve mover-se, gradativamente, no sentido da promoção da saúde, além de suas responsabilidades de prover serviços clínicos e de urgência. Os serviços de saúde precisam adotar uma postura abrangente, que perceba e respeite as peculiaridades culturais. (...) Uma 
mudança de atitude e organização dos serviços de saúde para que focalizem as necessidades globais do individuo, como pessoa integral que é." (MINISTÉRIO DA SAÚDE 1996)

À primeira vista, nada de novo ou que já não fizesse parte da discussão acumulada sobre as mudanças necessárias no setor. Destaca-se o que se definiu como novo, nesse documento, por postura mais abrangente do setor e que se evidencia, no depoimento acima apresentado: "Deve apoiar as necessidades individuais e comunitárias para uma vida mais saudável, abrindo canais entre o setor saúde e os setores sociais, políticos econômicos e ambientais."

Para o cumprimento dessas atribuições, colocam-se três procedimentos de interesse para os profissionais da saúde: defesa da causa de saúde ou "advocacy", mediação e capacitação.

P.B. "Na promoção da saúde, o que mais me interessa, é trabalhar os determinantes da saúde de caráter mais estrutural. Eu acho que em termos das funções de "advocacy", mediação, capacitação, a promoção da saúde pode agir no plano estrutural, inclusive politicamente. Quando eu movo, não o faço só tecnicamente, me movo politicamente como pessoa, na direção da promoção da saúde."

No depoimento acima, o entrevistado declara quais os aspectos do conceito de promoção que o interessa. Evidencia-se, mais uma vez, nesse estudo, que várias outras compreensões do conceito de promoção estão no cenário da saúde pública brasileira.

Uma das entrevistadas fez comentários a respeito da reorientação de serviços em termos de sua permeabildade ao saber popular ou às práticas 
populares de saúde, considerando, também, a atenção que se deve dar à diversidade cultural da população brasileira.

S.F. "Quando se fala em reorganizar o Serviço de Saúde, reorientar serviços de saúde como, por exemplo, na Carta de Ottawa, acho que nós, no Brasil, temos que repensar as práticas populares, as rezadeiras. Está começando ai, entendeu?"

D: Você estava considerando a permeabilidade do Saber Popular...

S.F. "É, na melhor orientação do serviço, o papel do municipio. O médico de familia que vai... Uma coisa que me chamou a atenção, por exemplo, quando eu comecei a trabalhar no Centro de Saúde de Itapecerica [São Paulo], foi a quantidade de migrantes nordestinos e a barreira da língua, da linguagem. Aprendi muitos termos nordestinos, muita coisa sobre ervas, utilização de ervas. Eu fazia o trabalho com as parteiras, com o treinamento de parteiras e de curandeiros no centro de saúde. Havia um curandeiro na região que era perseguido por médicos e farmacêuticos. Já tinha não sei quantos processos... Eu peguei esse curandeiro e fiz um trabalho, porque ele tinha uma liderança enorme junto a mulheres e a gestantes, e eu fazia um trabalho de integração. Mas isso era naquela época, em 76. Eu era uma autoridade sanitária na época e o pessoal me respeitava."

A incorporação do saber popular em saúde, no cotidiano dos serviços, é defendida visando desenvolver uma prática de saúde, cuja lógica não prendase ao saber técnico. A partir do reconhecimento de que a representação das pessoas sobre saúde-doença é fortemente influenciada pelos valores culturais e pela atuação de outros "cuidadores" da saúde da população são propostas algumas tentativas de integração. Busca-se, assim, melhorar a comunicação 
entre profissionais e população, humanizar o atendimento e reforçar práticas populares que favoreçam a saúde.

Discutiu-se alguns aspectos da Carta de Ottawa que evidenciam porque considera-se que ela consagra uma novo marco conceitual para o termo promoção da saúde. Percebe-se que esta requer ser mais estudada, pois a sua difusão, no mundo, tem subsidiado propostas que pretendem inovar o setor saúde. HANCOCK informa sobre a influência mundial deste documento(1998): "O resultado chave da I Conferência Internacional da Promoção em Saúde foi a adoção da Carta de Ottawa para a Promoção da Saúde, traduzida para mais de 50 línguas e que se tornou um guia para a promoção em saúde ao redor do mundo." 


\subsection{2- Declaração de Adelaide, 1988}

A II Conferência de Promoção da Saúde, realizada em Adelaide, em 1988, propós como tema central as Politicas Públicas Voltadas para a Saúde (Politicas Públicas Saudáveis), por entender que “(...) somente o conjunto de políticas públicas voltadas para a saúde estabelecerá o ambiente necessário para que as outras quatro ações mencionadas sejam possiveis." (MINISTÉRIO DA SAÚDE 1996)

Predomina a visão de que as politicas públicas saudáveis poderiam favorecer o projeto de reorientação de serviços e de desenvolvimento de habilidades individuais, inclusive em termos da participação comunitária e da cooperação por parte de diferentes setores da sociedade. Portanto, são renovados os compromissos com as cinco estratégias de ação propostas em Ottawa.

Alguns participantes deste estudo, ao longo da entrevista, relataram o que entendem por politicas públicas saudáveis. $O$ discurso se aproxima daquilo que conota no texto de Adelaide, embora, nesses depoimentos, inclua-se, também, alguns comentários sobre a necessidade daquelas não serem compreendidas apenas como sinônimos de politicas govemamentais.

I.C. "Sei que a saúde tem que trabalhar com o conceito da promoção da saúde e que a gente tem que fazer isso chegar aos outros setores, para que eles sejam capazes, também, de construir suas próprias políticas públicas. Elas têm que ter, como foco, 0 ato de criar situações mais favoráveis à saúde. A gente chama isso de políticas públicas saudáveis, ou seja, a gente trabalhar com 
todos os outros setores no sentido de que eles, ao formularem politicas, tenham como resultado mais saúde."

L.A. "Eu acho que a gente não deve confundir Politica de Governo com Política Pública. As pessoas confundem tudo isso. Eu tive muito enfrentamento quando tive que fazer palestras. Fui convidado pra dar palestras em alguns Sindicatos dos Trabalhadores. Eu ia falar sobre o SUS. Às vezes, a gente fala do SUS de forma tão empolgada, como se fosse uma política pública... E as pessoas que não têm noção... O sectarismo... Eu acho que é a palavra correta, acham que quando a gente está defendendo o SUS, a gente está defendendo o Governo. $E$ muito importante deixar claro que são duas coisas diferentes..."

J.Y. "A politica pública envolve o governo e a sociedade civil organizada. $E$ preciso saber o que é política pública e o que é política governamental.(...)"

Representantes de quarenta e dois paises formularam a Declaração de Adelaide, fundamentados nas seguintes afirmações:

"As iniquidades no campo da saúde têm raízes nas desigualdades existentes na sociedade. Para superar as desigualdades existentes entre as pessoas, em desvantagem social e educacional, e as mais abastadas, requer-se politicas que busquem incrementar o acesso daquelas pessoas a bens e serviços promotores de saúde e criar ambientes favoráveis. Tal política deveria estabelecer alta prioridade aos grupos mais desprivilegiados e vulneráveis. Além disso, uma política pública saudável reconhece como peculiar a cultura de povos indígenas, de minorias étnicas e de imigrantes. $A$ igualdade no acesso aos serviços de saúde, particularmente quanto aos cuidados primários, é um aspecto vital da equidade em saúde." (MINISTÉRIO DA SAÚDE 1996) 
Percebe-se. nesse documento, que a saúde é concebida como fator agregador, pretendendo que todos os setores da sociedade direcionem suas ações, norteados pela visão da saúde enquanto valor fundamental e assumindo, por outro lado, a prioridade do desenvolvimento social e econômico Ela deve ser privilegiada, por constituir "ao mesmo tempo em um direito humano fundamental e um sólido investimento social. " O documento alerta para - fato de que "novas desigualdades podem advir das rápidas mudanças estruturais resultantes das tecnologias emergentes." No entanto, não se refere às tendências dessas transformações. Apesar de todas essas consideraçōes, que mostram o caráter amplo que a saúde deve assumir e a necessidade de reforço da responsabilidade pública (accountability for health) em função da formulação dessas politicas, "os governos e os setores sociais que concentram recursos são igualmente responsáveis, perante os cidadãos, quanto às conseqüéncias das suas decisões políticas, ou pela falta delas, sobre a saúde das populações", esta declaração propõe apenas quatro áreas prioritárias de ação: apoio à saúde da mulher, alimentação e nutrição, tabaco e álcool e criação de ambientes saudáveis.

Ao se abordar cada uma das prioridades acima mencionadas, contudo, não se discute a forma pela qual a intersetorialidade deva ocorrer, isto é, não se apontam as formas de participação de cada setor (tributário, educacional, financeiro, planejamento, previdência etc.) para que se possa, assim, atingir os objetivos delineados. As referências limitam-se a dados específicos tradicionais da saúde. O que prevalece, nesse documento, é a recomendação de que as açōes da saúde sejam consideradas como "prioridade ou pré-requisito para o desenvolvimento industrial e da agropecuária" (MINISTÉRIO DA SAÚDE 1996)

O conceito accountability surge, pela primeira vez, na declaração de Adelaide. Em relação a isto, observa-se o trecho a seguir: 
P.B. “(...)Como é que eu faço a 'accountability', responsabilização de politica pública? Como é que eu formulo, implemento e avalio políticas públicas intersetoriais? Como é que eu dialogo com uma comunidade, que tem grupos de interesses cada um na sua área?(...)"

O documento em questão (declaração de Adelaide)só sinaliza que "um dos compromissos das políticas públicas voltadas à saúde deve ser o de medir e difundir o impacto destas politicas na saúde, em linguagem que os diferentes grupos sociais possam facilmente compreender. (...) devem ser desenvolvidos sistemas de informação para a saúde que apoiem este processo."

O conflito de interesses existente entre diferentes grupos sociais não é discutido. O problema ou conflito que esta Carta de "consensos" deixa perceber é a inadequada formação dos recursos humanos, frente às novas habilidades requeridas para o desenvolvimento de um conjunto de ações inovadoras, ligadas ao conceito de promoção da saúde.

Evidencia-se, no documento, a preocupação de constituir novos parceiros ou de compor novas alianças "visando a promover o incremento das ações de saúde." Nesse sentido recomenda-se que, a fim de que a saúde esteja "no topo da agenda dos políticos e dirigentes públicos", sejam constituídos grupos de trabalho, pesquisa e educação, envolvendo organizações não governamentais, sindicatos, comércio, indústria, associações acadêmicas, lideranças religiosas, instituições educacionais, mídia etc.

Destaca-se, nesta declaração, o reconhecimento de que governos e setores sociais são igualmente responsáveis pela saúde (responsabilidade pública). Pela primeira vez aparecem as lideranças religiosas como "parceiras neste processo político". 
"Esta Conferência defende que, como prioridade, a saúde pública e os movimentos ecológicos juntem suas forças para desenvolver estratégias comuns, visando obter 0 desenvolvimento sócio-econômico $e$, simultaneamente, a conservação dos limitados recursos do planeta."

Os participantes da Conferência, procedentes dos paises que compõem a Região Européia da OMS, reafirmam o compromisso com a meta concernente à Saúde Para Todos: "no ano 2000, as diferenças atuais no nivel de saúde entre países, e entre grupos num mesmo país, devem ser reduzidas, ao menos, em $25 \%$, melhorando o nivel de saúde das nações e grupos desprivilegiados."

Nessa declaração, a reforma social, é em vários momentos associada à reforma do setor saúde, uma vez que os pré-requisitos para a saúde são considerados os mesmos do desenvolvimento social. São eles: paz e justiça social; alimentação adequada; educação e moradia decentes; renda adequada; água potável; conservação dos recursos naturais e proteção do ecossistema; um papel profícuo na sociedade. É relevante observar que os três últimos requisitos não constavam na Carta de Ottawa.

No depoimento abaixo a visão de promoção da saúde se aproxima da referenciada em Adelaide.

I.C. "No caso especifico do nosso contexto, numa visão pessoal do rumo que ela precisaria tomar, na situação do Brasil, a promoção precisaria tomar alguns rumos, que no caso, na questão da gente, seriam rumos mais inclusores, rumos que tivessem a ver com a inclusão social. Promoção social, para nós, representa incluir um leque muito substantivo da nossa população para que tenha, pelo menos, as mesmas oportunidades de viver das outras pessoas. Que tenham as mesmas expectativas de vida, que tenham no mínimo, um direito fundamental, que é o direito de ter os mesmos riscos de adoecer e de 
morrer de outros grupos da sociedade. Hoje nós já temos um aparato suficiente para isso, então promoção para a gente, ela tem que no primeiro momento representar a possibilidade de termos o mínimo de equidade. Nesse sentido, que todos sejam iguais perante, pelo menos, o direito de ter uma longevidade, uma qualidade de vida e ter riscos de adoecer similares."

A expectativa que este entrevistado tem quanto ao desenvolvimento da promoção da saúde no Brasil se relaciona com a visão de promoção social.

I.C. "A expectativa principal, é uma questão que pra nós é chave, essa questão de garantir a todas as famílias, a todos os cidadãos brasileiros, um ingresso mínimo ou que eles tenham oportunidades mínimas de se inserirem; se inserirem de uma forma diferente da que estão agora. Um conjunto muito expressivo dos brasileiros está absolutamente alijado. E, aí, não é só dos brasileiros individuos, mas dos brasileiros, também, enquanto comunidade, coletividade. Temos, por exemplo, municipios que são absolutamente excluídos. Nós temos municipios que têm IDHs (índice de Desenvolvimento Humano) extremamente baixos e que têm mortalidade infantil extremamente elevada. Há municípios totalmente excluídos dos mecanismos de funcionamento da sociedade brasileira. De mecanismos de onde pegar recursos, de onde captar, de onde até adquirir tecnologias de conhecimento, de como trabalhar situações ou de como mudar de uma situação para uma outra. Então ai o leque é muito expressivo. O Brasil é muito desigual. Esta questão de equidade é chave."

Esta Conferência defende como prioridade, que a saúde pública e os movimentos ecológicos juntem suas forças para o desenvolvimento sócioeconômico e, simultaneamente, dos limitados recursos do planeta.

\footnotetext{
- O Índice de Desenvolvimento Humano foi criado em 1990 pelo Programa das Nações Unidas para o Desenvolvimento (PNUD), visando medir a qualidade de vida. Combina três indicadores básicos: expectativa de vida, educação e renda.
} 
Essa aproximação da saúde pública com outros movimentos é relatada pelo entrevistado P.B:

P.B. "Nós [ENSP] estamos tentando desenvolver, no nivel local, o tema das políticas públicas saudáveis. Começamos a desenvolver um grupo de trabalho, um estudo sobre desenvolvimento local. Entendendo-se que é no nível local, aquelas coisas: 'pensar global, agir local'. Plugando a Agenda $21^{\circ}$ com promoção da saúde, com Direito à Cidade e à Moradia de Istambul, com a questão da exclusão e da pobreza, juntando um pouco as conferências internacionais, fazendo um grande caldo. Pensei o seguinte: como é que nós podemos fazer um bairro saudável sem promover o desenvolvimento, já que nós entendemos que os determinantes são os fatores extra-setoriais? Como superar a retórica do discurso da intersetorialidade, da multicasualidade, dos determinantes extra-setoriais e não fazer nada? $E$ só fazendo 'advocacy'? Ou é tentando fazer a mediação? Que é aquela segunda função: mediação dos grupos de interesse da sociedade e destes com o Estado. E como é que eu articulo o Estado? Ou seja, a presença do poder público aqui?"

P.C. “(...) Entendo a promoção da saúde como uma mudança na agenda, que orienta as ações, os programas, os investimentos, as políticas de saúde. Claro que para mim também é importante este referencial de compor, de um lado, com uma atitude individual, este apoio, se você for pegar as definições clássicas da Promoção de Saúde, que vêm aí dos encontros, dos fóruns mundiais a respeito deste tema, a gente pega este valor que se dá à informação, à formação de pessoa para uma conduta diante de uma vida mais saudável etc. Mas, ao mesmo tempo, faz este 'link' com a mudança, o sentido

\footnotetext{
"Agenda 21, segundo JUNQUEIRA (1998a): "é o principal documento resultante da Conferencia das Naçoes Unidas sobre Meio Ambiente e Desenvolvimento Humano (ECO-92). É um guia para que a humanidade caminhe em direçăo a um desenvolvimento socialmente justo, economicamente viável e ambientalmente sustentável"
} 
coletivo, que eu acho que é o grande movimento que tem de se fazer mesmo, para que você o nível de investimento que se faz hoje na saúde, ele é quase que 'kamikase', quanto mais se investe, mais você deixa de controlar certos processos que de fato determinam a qualidade de vida das pessoas, a extensão da vida .(..." 


\subsection{3- Declaração de Sundsvall, 1991}

Na III Conferência Internacional sobre Promoção da Saúde, Ambientes Favoráveis à Saúde, realizada em Sundsvall, em junho de 1991, continua-se apontando a necessidade de contar tanto com a ação individual, quanto com a ação coletiva, devendo-se “(...) envolver, predominantemente, setores como a educação, transporte, habitação, desenvolvimento urbano, produção industrial e agricultura." (MINISTÉRIO DA SAÚDE 1996) Nessa Conferência 81 paises estiveram presentes.

A Declaração de Sundsvall denuncia as desigualdades sociais que têm sido responsáveis pela exclusão social, no mundo, mostrando seus reflexos na saúde da população mundial. No documento diz-se:

“No contexto da saúde, o termo 'ambientes favoráveis' refere-se aos aspectos físico e social do nosso entomo. Este termo alcança os espaços nos quais as pessoas vivem: a comunidade, suas casas, seu trabalho e lazer. Também engloba as estruturas que determinam o acesso aos recursos para viver e as oportunidades para ter maior poder de decisão. As ações possiveis para a criação de ambientes favoráveis e promotores de saúde têm diferentes dimensões: física, social, espiritual, económica e política. Estas dimensões estão inextrincavelmente ligadas em uma interação dinâmica. As ações precisam ser coordenadas, tanto no nivel local, como nos níveis regional, nacional e mundial, para encontrar soluções verdadeiramente sustentáveis." (MINISTÉRIO DA SAÚDE 1996)

Diferentemente das duas Declarações anteriores, na Declaração de Sundsvall, nota-se a preocupação em definir os conceitos teóricos, para que 
possam, assim, ser melhor operacionalizados na prática. Pode-se tomar, por exemplo, o conceito acima apresentado de "ambientes favoráveis". Ainda, mais explicito, discute-se os significados dos termos "equidade" e "desenvolvimento sustentável".

Ampliam-se aqui as possibilidades de envolver diferentes locais e setores nas ações e atividades relacionadas à promoção da saúde. Além dos serviços de saúde e da legislação, que devem favorecer escolhas mais saudáveis por parte dos cidadãos, recomenda-se que as ações passem a ser desenvolvidas em centros de recreação, igrejas, entidades associativas, conselhos locais e empresas, entre outros. Pressupõe, também, o compromisso da sociedade democrática no sentido de elaborar um contrato e de garantir seu cumprimento, de forma a assegurar o direito à vida com saúde.

Assume-se, ainda, que os conhecimentos de povos, que "gerenciam os recursos naturais, levando em consideração as necessidades das futuras gerações" devem ser valorizados e incorporados no planejamento das atividades de desenvolvimento sustentável. A título de exemplo deste tipo de contribuição, cita-se os povos indigenas. Este grupo populacional, até então excluído das discussões do setor saúde, é incluído nessa declaração por ter um saber a ser incorporado. Entre os ensinamentos relevantes desse povo, destaca-se, seu relacionamento com o meio ambiente, considerando, além dos aspectos físicos, suas dimensões espirituais e culturais. Por consequência, estabelece-se com o entorno uma relação mais harmônica ou menos predatória, ensinamento fundamental para melhorar a relação dos seres humanos com a natureza, o meio ambiente e seus recursos.

Nessa Declaração se explicita que as estratégias, ali apresentadas, para a ação em saúde pública, se fundamentam no pressuposto de que: "Aumentar o poder de decisão das pessoas e a participação comunitária são fatores 
essenciais num processo democrático de promoção da saúde e a força motriz para a auto-confiança e o desenvolvimento."

No tópico intitulado Por uma prestação de contas global, da mesma Declaração, recomenda-se:

"A OMS e a UNEP (Programa das Nações Unidas para o Ambiente) devem desenvolver guias e manuais baseados nos principios do desenvolvimento sustentável, para uso dos Estados Membros. Os doadores e agências de financiamento, multilaterais ou bilaterais, como o Banco Mundial e o FMI [Fundo monetário Internacional] devem utilizar guias e manuais no planejamento, implementação e avaliação de projetos. São necessárias providências urgentes para apoiar os paises em desenvolvimento a identificar e utilizar suas próprias soluções ao processo de desenvolvimento. Uma estreita colaboração com as ONGs deve ser assegurada durante este processo." (MINISTÉRIO DA SAÚDE 1996)

Entre as atribuições ou ações propostas para a saúde pública, ressaltase aqui: "Mediar os interesses conflitantes na sociedade, de modo que se possa assegurar o acesso igualitário a ambientes favoráveis à saúde."

A Declaração reconhece a existência de uma série de conflitos oriundos da má distribuição dos recursos, como reflete o texto abaixo:

"Milhões de pessoas estão vivendo em extrema pobreza e privação, num meio ambiente cada vez mais degradado, tanto nas zonas rurais como urbanas.(...) Milhões de pessoas não têm acesso à educação básica e têm pouca esperança num futuro melhor. (...)Mais de um milhão de pessoas no mundo têm acesso inadequado aos cuidados básicos (essenciais) de saúde. (...)" (MINISTÉRIO DA SAÚdE 2001) 
Outros tipos de desigualdades são citados na Declaração de Sundsvall:

“O mundo industrializado precisa pagar o débito humano e ambiental que acumulou através da exploração do mundo em desenvolvimento.(...) A pobreza frustra o desejo e os sonhos das pessoas de construirem um futuro melhor, enquanto seu acesso limitado às estruturas políticas solapa as bases da autodeterminação. (...) As mulheres, maioria da população mundial, ainda são muito oprimidas - são sexualmente exploradas, sofrem discriminação em várias áreas. (...) As decisões políticas e o desenvolvimento industrial estão quase sempre baseados em planejamento e ganhos econômicos de curto prazo, que não levam em conta os verdadeiros custos quanto à saúde das populações e o meio ambiente. A dívida externa drena os escassos recursos dos paises pobres."

Lê-se no texto final da Declaração:

"Os participantes da Conferência solicitam à Conferência das Nações Unidas do Meio Ambiente e do Desenvolvimento (UNCED), que será realizada no Rio de Janeiro, em 1992, que considere a Declaração de Sundsvall nas deliberações sobre a Carta da Terra e a Agenda 21, consideradas um plano de ação com vistas ao próximo século. As metas e os objetivos da saúde devem ter uma presença dominante em ambos os documentos. Somente uma ação global, baseada numa parceria entre todas as nações, assegurará o futuro de nosso planeta."

Um dos entrevistados, presente nesta conferência, comenta como proceder para atender à solicitação de integrar o movimento da promoção da saúde a outros movimentos: 
P.B. "Muito bem, na década de 90, nessa escola [ENSP], nós começamos a trabalhar, a partir de Sundsvall, na direção da Conferência de 92. Produzimos inclusive um pequeno documento que não falava na palavra promoção, mas foi uma contribuição...

D. Foi uma tentativa de articular..

P.B. "Sim. Mas, tem um livro nosso que se chama 'Saúde, ambiente e desenvolvimento', em dois volumes, da HUCITEC, de 1992, que nós lançamos no mês da Conferéncia. A gente fez, são sessenta autores, uma coletánea com uns vinte artigos, mais ou menos, que a gente fez em um processo longo de construção. Está escrito por mim na introdução desses dois volumes, e que era essa idéia de saúde, ambiente e desenvolvimento. Ou seja, é uma idéia de um conceito de saúde expandido, de um conceito de sáude... Como se diz?... Conceito ampliado de saúde, com a discussão da resposta multisetorial etc, etc... Na reunião de Sundsvall eu não a compreendi assim. Quer dizer, eu não compreendi a reunião de Sundsvall como parte de um processo. Eu estava ingenuamente, entrando na terceira conferéncia sem reconhecer o movimento internacional de promoção da saúde." 


\subsection{4- Declaração de Jacarta, 1997}

A IV Conferência Internacional sobre Promoção da Saúde foi realizada em Jacarta - Indonésia, com o título: "Novos Protagonistas para uma Nova Era. Orientando a Promoção da Saúde pelo Século XXI adentro." Caracteriza essa Conferência o fato de ter sido: "a primeira a ter lugar em um pais em desenvolvimento e a primeira a incluir o setor privado no apoio à promoção em saúde."

Onze anos após a realização da I Conferência Internacional (Ottawa, 1986), reconhece-se que a Carta de Ottawa "tem servido como fonte onientadora e de inspiração para a promoção da saúde."

\section{De acordo com a Declaração de Jacarta:}

"A saúde é um direito humano fundamental e essencial para o desenvolvimento social e econômico. (...) A promoção da saúde é um processo que, mediante investimentos e ações, atua sobre os determinantes da saúde para criar o maior beneficio para os povos, para contribuir de maneira significativa para a redução das iniqüidades em questão de saúde, para assegurar os direitos humanos e para a formação do capital social."

Introduz-se, então, o conceito de capital social" no conceito guarda-chuva da promoção da saúde, porém, ao longo do documento, ele não é qualificado. $\mathrm{A}$

\footnotetext{
- Segundo KAWACHI et al (1997) capital social: "consiste do engajamento cívico e niveis de confiança mútua entre os membros de uma comunidade. Engajamento civico refere-se ao grau de envolvimento que os cidadăos tem com suas comunidades e, é mais, frequientemente, medida pelo número de membros participantes em grupos ou associaçठes."
} 
idéia subjacente a este conceito é a de que uma menor associabilidade civica, assim como, a falta de confiança entre os membros de uma determinada comunidade leva a menor participação social e, consequentemente, presta-se menos atenção às ações públicas. Essa preocupação se fundamenta em alguns estudos que têm buscado a relação existente entre aumento das iniquidades e as taxas de mortalidade, tendo como critério o grau ou o investimento em capital social. (KAWACHI et al. 1997)

Como na Carta de Ottawa, essa Declaração, apresenta os pré-requisitos que contribuem para a saúde: paz, abrigo, instrução, segurança social, relações sociais, alimento, renda, direito de voz das mulheres, eco-sistema estável, uso sustentável de recursos, justiça social, respeito aos direitos humanos e eqüidade. A pobreza é, acima de tudo, a maior ameaça à saúde. É interessante observar que o termo moradia (pré-requisito em 1986) é substituido por abrigo, sendo o termo "educação" substituído por "instrução". Outro ponto a ressaltar, é a inclusão no debate, o direito de voz das mulheres, quesito destacado em termos do conjunto de direitos humanos.

Após uma exposição sobre o cenário que prevalece, na atualidade, para o campo da saúde, afirma que "a promoção da saúde é um enfoque prático para a obtenção de maior equidade em saúde", o documento indica as prioridades para o século 21:

"1.promover a responsabilidade social para com a saúde;

2.aumentar os investimentos para fomentar a saúde (abordagem multisetorial) - necessidades dos grupos da população;

3.consolidar e expandir parcerias em prol da saúde;

4. aumentar a capacidade comunitária e direito de voz ao indivíduo;

5.conseguir uma infra-estrutura para a promoção da saúde." 
Evidencia-se, nessa declaração, que a necessária construção ou estabelecimento de parcerias tem encontrado alguns obstáculos: "Existe uma flagrante necessidade de derrubar as fronteiras tradicionais dentro dos setores públicos, entre organizações governamentais e não governamentais e entre os setores público e privado." Porém, ao longo do texto, não se identificaram os empecilhos a serem superados.

No trecho de entrevista abaixo, fazem-se comentários a respeito de aspectos ligados a pretendida construção de parcerias:

V.P. "Ninguém tem recurso para cobrir tudo. Quer dizer, a questão financeira ficou muito forte, começa um esforço de parceira que tem rendido muito. As instituições procuram se combinar, começam a se juntar de alguma maneira. Então, nós aqui [SESI] estamos tentando por ai na questão da parceria, o que não é fácil, pois cada instituição continua com a sua cultura*. Mas todo tipo de parceria tem sido bem vinda para todos."

O nivel local é identificado como esfera privilegiada para a implementação de estratégias de promoção da saúde: "localidades para a saúde representam a base organizacional da infra-estrutura necessária para a promoção da saúde."

S.F. "Eu tinha para mim, que o local, em termos de poder e territónio, sempre foi o município. Tinha dificuldade em pensar em um modelo dentro de uma área deslocada, setorizada. Para mim, o municipio sempre foi o 'locus' de elaboração das políticas.."

Ao final da Reunião, "os participantes referendam a formulação de uma Aliança Mundial Para a Promoção da Saúde", apoiada nos seguintes tópicos: 
- maior sensibilidade em relação à mudança dos determinantes da saúde;

- apoio à criação de atividades de colaboração e de redes para o desenvolvimento sanitário;

- mobilização de recursos para a promoção da saúde;

- acumulação de conhecimentos sobre as melhores práticas;

- facilitação do aprendizado compartilhado;

- promoção de solidariedade em ação;

- transparência e responsabilidade pública de prestação de contas em promoção da saúde.

A Declaração de Jacarta atribui um significativo papel à OMS, a qual deve "exortar as organizações governamentais e não-governamentais, bancos de desenvolvimento, agências da ONU, órgãos inter-regionais, agências bilaterais, sindicatos e cooperativas, assim com o setor privado, a promover as prioridades das ações para a promoção da saúde." (MINISTÉRIO DA SAÚDE 2001)

Outro conceito introduzido, em Jacarta, sobre a discussão de promoção da saúde, foi o de rede (network). "novos desafios sanitários significam que redes novas e diversificadas têm de ser criadas para se conseguir a colaboração intersetorial."

Destaca-se a seguir algumas apropriações internacionais e nacionais deste termo. Seguindo as diretrizes de Jacarta, foi criada, em março de 1998 , em Genebra - Suiça, a Rede de Megapaíses para a Promoção da Saúde da OMS. Esta foi proposta com o objetivo de: "possibilitar um impacto na saúde mundial por meio da formação de uma aliança entre os paises mais populosos. Juntos, estes megapaises atingem $60 \%$ da população do mundo: Bangladesh,

\footnotetext{
- Grifo da autora.
} 
Brasil, China, India, Indonésia, Japão, México, Nigéria, Paquistão, Federação Russa e Estados Unidos da América."

Os entrevistados, nesta pesquisa, referem-se a algumas possibilidades ou compreensões do que constitui rede na realidade brasileira, como se mostra a seguir.

O coordenador do Programa de Promoção da Saúde do Ministério, um dos entrevistados neste estudo, fala a respeito do papel que têm assumido na articulação de redes.

I.C. “(...)A gente tem procurado fomentar redes nesse sentido, de trabalhar com a promoção da saúde. Às vezes não apenas só com os que trabalham, especificamente, com o conceito da promoção da saúde, mas redes que, ao trabalhar determinadas questões, determinados assuntos ou determinados temas, estão trabalhando em promoção da saúde. Essa é uma das estratégias da gente. Existem vários locais que trabalham com a promoção da saúde e que nós temos tentado agregá-los, torná-los próximos e potencializar as ações desses locais. Mais do que difundir uma idéia de promoção da saúde, acho que talvez seja mais importante difundir, exatamente, as questões com que ela trabalha, os conceitos com que ela trabalha. (...)

Uma das idéias que a gente tinha era a de ter uma discussão mais sistemática da questão da promoção da saúde. Nós pensamos em algumas coisas que poderiam representar alguns encontros sobre promoção da saúde $e$ alguns encontros que fomentassem temas ou tecnologias especificas. Considera-se a própria Rede Brasileira de Municipios Saudáveis, que a gente está tentando ajudar, da melhor forma possivel, para que possa chegar aos prefeitos e gestores municipais, como uma metodologia, ou seja, como uma forma, um jeito de abordar a gestão do municipio." 
A rede, da qual o entrevistado se refere, teve seu mandato formulado através de 8 princípios ou objetivos de trabalho, propostos na Declaração de Fundação da Rede Brasileira de Municipios Saudáveis. Esta rede foi lançada em agosto de 1999, no XV Congresso Nacional de Secretários Municipais de Saúde, no Rio de Janeiro. Foi elaborada por representantes de municipios de todas as regiões do Brasil, sendo a maioria da região nordeste.

As tarefas ou mandatos atribuídos à Rede variam desde a sensibilização de outros prefeitos, no Brasil, para a proposta de Municípios Saudáveis, à difusão e intercâmbio de todas as iniciativas nacionais já existentes. Destaca-se aqui duas atribuições ( $n^{\circ} 3$ e 8 ) conferidas a essa Rede, de interesse para este estudo: "difundir suas ações no sentido de criar um verdadeiro movimento social em prol da qualidade de vida no seio da sociedade brasileira e vincularse ao movimento internacional de cidades saudáveis, fomentando o intercâmbio com iniciativas internacionais."

S.F. "Considero que a minha contribuição nesse nivel é no sentido de articular esta rede (Rede Brasileira de Municípios/Cidades Saudáveis). Porque, como eu Ihe disse, se não for no nivel de municipio, isso não vai acontecer.

(...)Porém, eu considero outros fóruns hoje mais importantes do que estes da saúde. Por exemplo: os encontros Habitat, encontros do meio ambiente, a Agenda 21, que é uma das idéias mais avançadas que se tem hoje, mais do que a própria promoção da saúde. Acho que nós, da saúde, temos que nos articular com estes movimentos mais amplos. Por isso eu falo de rede. Tendo, cada vez mais, a ser uma pessoa de rede, rede, rede... Ampliando para o meio ambiente, a questão mulher, a questão saúde, a questão das minorias, a coisa da tomada de consciência, que você tem que atuar em outro nível." 


\subsection{5- Declaração do México, 2000}

A V Conferência de Promoção da Saúde, não mais intitulada de "Internacional", e sim, de "Global", foi realizada na cidade do México, em junho de 2000, sob o tema: Promoção da Saúde - Rumo a uma Maior Equidade. Dela procede uma Declaração Ministerial, endossada por ministros e delegados de aproximadamente 100 paises, contendo orientações para a preparação de planos de ação nacionais dirigidos à promoção da saúde. Com vistas à operacionalização de atividades adotou, como subtítulo, "Das idéias às ações".

Um dos entrevistados participou da programação desta Conferência, ao representar o Ministério da Saúde, como mostra o depoimento a seguir:

J.Y. "Participei do estudo da proposta da Conferéncia [V], durante a reunião da Conferência dos Megapaíses, em março deste ano, no México. Concomitantemente, havia um grupo da OMS discutindo com as autoridades mexicanas a temática da Conferéncia. Tive chance de estar ali, influindo no evento. Chamei a atenção para o fato de se estar pensando em convocar só o setor saúde, porque isso contradizia o conceito de promoção de saúde, que é intersetorial. Tudo bem em chamar os funcionánios da saúde, mas deveniam ser chamados, também, outros setores, que tiveram uma experiencia positiva na construção do conceito de promoção de saúde. Isso foi aceito."

Segundo CATFORD (2000), essa Conferência diferiu das quatro anteriores, não só por incluir programas ministeriais, mas também por permitir que Ministérios e Delegados Ministeriais apresentassem experiências que haviam tido com Promoção da Saúde. Teve autoridade, portanto, para afirmar que: "a promoção da saúde e o desenvolvimento social são dever $e$ 
responsabilidade centrais dos governos", compartilhadas por todos os setores da sociedade" (MINISTÉRIO DA SAÚDE 2001)

Foram propostas como ações:

"a - Colocar a promoção da saúde como prioridade fundamental das políticas e programas locais, regionais, nacionais e internacionais.

b - Assumir o papel de liderança para assegurar a participação ativa de todos os setores e da sociedade civil na implementação das ações de promoção da saúde, que fortaleçam e ampliem as parcerias na área da saúde.

c - Apoiar a preparação de planos de ação nacionais para a promoção da saúde, se necessário utilizando a capacidade técnica da OMS e de seus parceiros nessa área.

$d$ - Estabelecer e fortalecer redes nacionais e internacionais que promovam a saúde.

e - Defender a idéia de que os órgãos da ONU sejam responsáveis pelo impacto na saúde da sua agenda de desenvolvimento.

$f$ - Informar ao diretor-geral da Organização Mundial da Saúde, para fins do relatório a ser apresentado à $107^{a}$ sessão da Diretoria Executiva, do progresso registrado na execução dessas ações." (MINISTÉRIO DA SAÚDE 2001)

Considerando a preocupação manifestada por esse documento com o monitoramento do progresso das ações, recorda-se aqui a meta proposta, na Declaração de Adelaide, para os paises pertencentes à Região Européia da OMS, até o ano 2000: "reduzir, no mínimo, em $25 \%$ as diferenças no nível de saúde entre países e entre grupos num mesmo país." Esta meta não foi mencionada na Declaração do México e nem uma outra foi identificada.

\footnotetext{
- Destaque da pesquisadora.
} 
Quatro entrevistados manifestaram, no periodo de realização das entrevistas, sua intenção de comparecer a esta Conferência. Três deles falaram sobre as respectivas participaçōes em evento organizado pela Oficina Permanente de Estudos de Saúde Pública - Programas sobre Cidades/Municipios Saudáveis, da Faculdade Saúde Pública/USP, em outubro de 2000.

S.F. "(...)Vou agora a esta conferéncia no México. Estou com uma expectativa muito grande, porque acho que vai ser um encontro importante. No começo do século, este evento vai permitir reunir pessoas que estão repensando a saúde pública. (...) Acho que este fórum da promoção é o grande fórum. (...)" 


\subsection{6- Declaração de Bogotá, 1992}

Visando a resguardar as especificidades de cada pais ou região, em 1992, na cidade de Bogotá, a Organização Pan-Americana de Saúde e o Ministério de Saúde da Colômbia, promoveram uma Conferência para "definir o significado da promoção da saúde na América Latina."

Na Declaração de Bogotá (MINISTÉRIO DA SAÚDE 1996) diz-se:

“(...) A Região, assolada pela iniquidade que se agrava pela prolongada crise económica e pelos programas das políticas de ajuste macroeconómico, enfrenta a deteriorização das condições de vida da maioria da população, junto com o aumento dos riscos para a saúde e a redução dos recursos para fazer frente a esta situação. Dessa maneira, o desafio da promoção da saúde na América Latina consiste em transformar as relações excludentes, considerando interesses económicos e propósitos sociais de bem estar para todos. Assim, deve-se trabalhar para a solidariedade e a equidade social, que são condições indispensáveis para a saúde e o desenvolvimento." (MINISTÉRIO DA SAÚDE 1996)

Essa Conferência traça suas principais estratégias e compromissos para a promoção da saúde na América Latina. Entre estes, destaca-se: "fortalecer as capacidades da população para participar nas decisões que afetam sua vida e para optar por estilos de vida saudáveis." (MINISTÉRIO DA SAÜDE 1996)

Um dos entrevistados informou ter participado da Conferência de Bogotá, que contou com 550 representantes de 21 paises. 
J.Y. "Na América Latina, eu participei na Colômbia, em Bogotá."

Na Declaração diz: "A situação de iniquidade da saúde nos paises da América Latina reitera a necessidade de se optar por novas alternativas na ação de saúde pública, orientadas a combater o sofnimento causado pelas enfermidades do atraso e pobreza, ao que se sobrepõem os efeitos colaterais causados pelas enfermidades da urbanização e industrialização."

A afirmação acima é compartilhada por uma das entrevistadas, como se observa a seguir:

V.L. "Eu acho que, no caso brasileiro, assim como grande parte da América Latina, a questão da equidade, desta desigualdade enorme, da iniquidade que existe. Pra mim, este é o problema central na promoção. Eu acho que todas as forças deveriam estar, realmente, voltadas para a superação desta iniquidade. Pelo menos, para algum progresso nesta área. Eu acho que, o qué me chama mais atenção é isto.(...)"

Essa Conferência reitera um aspecto já identificado na declaração de Sundsvall: faz-se necessário garantir a participação democrática nos processos de decisão e descentralização de recursos. Na América Latina, foi discutido o fato de ainda existirem "na ordem política, barreiras que limitam o exercício da democracia e a participação da cidadania na tomada de decisões. Nessas circunstáncias, a violéncia - em todas as suas formas - contribui muito para a deteriorização dos serviços, causando inúmeros problemas psicossociais, além de constituir o fundamento de significativos problemas de saúde pública." Defende-se, então, "a incorporação das propostas da Carta de Ottawa para a estratégia de promoção da saúde na América Latina." 
Ao final da discussão das cartas apresentam-se alguns aspectos considerados importantes pelos entrevistados:

Ao ser perguntado sobre as estratégias ou meios delineados para atingir os objetivos da promoção da saúde, um entrevistado assim se pronunciou:

A.V. "Acho que as cinco estratégias da Carta de Ottawa (elaboração e implementação de políticas públicas saudáveis, criação de ambientes favoráveis à saúde, ação comunitária, desenvolvimento de habilidades e reorientação dos serviços de saúde) e mais as outras cinco estratégias de Jacarta (promover a responsabilidade social para com a saúde; aumentar os investimentos para fomentar a saúde - abordagem multi-setorial; consolidar e expandir parcerias em prol da saúde; aumentar a capacidade comunitária e direito de voz ao indivíduo; conseguir uma infra-estrutura para a promoção da saúde) são as mais importantes. A Carta de Ottawa fala do 'empoderamento', digamos, da intenção de aprimorar e fortalecer a capacidade da população para tomar decisões. Por outro lado, a Carta de Jacarta chama a atenção sobre os aspectos da responsabilidade social. Acho que as duas colocam com mais clareza os aspectos estratégicos da promoção da saúde."

P.C. "O conceito de promoção da saúde de Ottawa é ainda limitado. Não estou querendo ser pretensioso mas, eu acho, me colocando agora como observador e como agente neste processo, que foca ainda o indivíduo. Mas, este documento [Carta de Ottawa] ainda é importante por dizer: 'Não é com hospital e remédio, é com atitude. Tem relação com vida saudável', mostrando que o indivíduo é um pouco responsável por isso. Quer dizer, é... fazer com que o próprio individuo tenha atitudes, responsabilidade. As campanhas contra o fumo, contra o alcoolismo, contra acidentes são importantes e têm um impacto importante, mas são limitadas. Na verdade, a promoção da saúde já assume o compromisso de intervir politicamente e integradamente com outras áreas, 0 
que representa um avanço devido, também, à promoção da saúde. Começar a buscar diálogo com a área de planejamento urbano, com a área de educação, com a área de transporte, com aquilo que tecnicamente se constitui numa outra área, num outro campo de conhecimento, mas que determina o padrão de vida das pessoas, sua qualidade de vida e até mesmo se vão morrer mais cedo ou mais tarde. Acho que este avanço ocorreu. No campo teónico já começa a aparecer alguma coisa no sentido estratégico de como se pode fazer isso. $O$ conceito formal da reunião de Ottawa acabou influenciando outro movimento o movimento de cidades saudáveis, que traduz um pouco melhor isto. Traduz um pouco mais a realidade urbana, movimento que hoje, mundialmente, atinge grande parte da população.(...)"

Sabe-se que os documentos (declarações das conferências) aqui analisados, resultam de plenárias, relatórios de discussões de grupo e, como tais, constituem protocolos de realizações. Fato este sinalizado por uma dos entrevistados:

L.A. "Eu acho que essas cartas são documentos importantes, são referéncias, um conjunto de intenções, de pactos, mas são também documentos multilaterais. São documentos de grandes consensos, digamos, genéncos, por isso, na realidade, não colocam essa coisa muito clara."

D. Cartas de intenções ...

$\checkmark$ L. "Cartas de intenções, ficam na intenção... Todos concordam que é importante, mas os passos necessários não são dados. Há sempre grupos ou, enfim, há setores que são prejudicados... Eu estou me lembrando de uma conferência. Vocé conhece Hiram Arroryo? É uma autoridade nessa instituição, nessa organização, é vice-presidente da UIPES. Fez uma conferência, em 1997, aqui no Rio Janeiro, falando sobre promoção e sobre questões críticas. 
Ele citou uma frase... Não sei se é do [Carl Lee]. Não sei se era de um americano, ou de um canadense. Essa pessoa dizia: 'Quando a promoção funciona, começa a oposição política'. Há sempre os setores que se incomodavam com aquele passo. A luta de poder, a luta hegemónica dos diferentes setores. A gente sabe bem como é isso. Até trabalhando dentro de uma instituição você tem os departamentos...." [Pausa]

D. Na verdade, era uma preocupação com o conflito na sociedade. A disparidade de interesses..

V.L. "Em todos os niveis há esta dificuldade de articulação, de trabalho integrado. Há disputas, há interesses, há todo um tipo de barreira, digamos assim, para que estes objetivos maiores sejam, realmente, tocados para frente. Por isso acho que é a sociedade que tem que fazer a grande mudança, é a própria população. (...) Eu acredito na educação da sociedade, das pessoas.. Eu acho que as coisas acontecem a partir dai, porque a proposta, como um todo, é muito bonita, mas ela me parece um pouco utópica. Eu acho que se a gente for considerar, por exemplo, a quantidade de compromissos que são assumidos nas conferéncias Internacionais, não apenas de promoção, mas na ECO 92, na Alma Ata, em 1978, e assim por diante, se estes compromissos tivessem sido cumpridos a gente já teria dado passos gigantes, fabulosos... Na realidade há uma série de compromissos que não são cumpridos e de planos que não chegam a ser implementados.(...)

No final da análise dos principais documentos da promoção da saúde, confirma-se a visão de BUNTON e MACDONALD (1992), citada no tópico anterior: o conceito promoção da saúde vem se apresentando como um conceito guarda-chuva, sendo associado a vários outros que, na maioria das vezes, estão pouco definidos. 
GENTILE (2001), no capitulo sobre "A promoção da saúde e as Cartas: de intenções escritas à operacionalização das ações", diz que: "A Promoção da Saúde, enquanto conceito, está se constituindo aqui como a resina agregadora de um mosaico composto por principios de ação e compromissos para se alcançar a meta de Saúde para Todos e a elevação da qualidade de vida e bem estar da população."

A imagem de "resina agregadora" se aproxima dos aspectos relatados por alguns dos participantes deste estudo. Reconhecem a capacidade ou a possibilidade do conceito de promoção da saúde reunir vários princípios ou propostas que hoje coexistem no cenário contemporâneo da saúde, favorecendo, assim, a construção de consensos. Além disso, conferem a ele, ainda, um potencial de integração(idéia-força) ou de organização, conforme pode ser observado nos depoimentos abaixo:

V.L. “(...)Como os próprios autores interessados ou divulgadores da promoção dizem: 'não há, necessariamente, grandes novidades'. Há uma proposta que ordena e organiza toda esta questão, de uma nova maneira."

D. São inquietudes, interesses já colocados?

V.L. "É, é... é uma novidade organizacional. Não é uma novidade, vamos dizer assim, em termos de propostas isoladas, porque 'empowerment', por exemplo, já se faz há muito tempo. Já era uma grande preocupação nossa."

A respeito do conceito agregador da promoção da saúde, assim se manifestou um dos entrevistados:

I.C. "'É um grande movimento, talvez mundial, de sintese. A gente tem passado por períodos e momentos históricos em que a questão da fragmentação tem perdido terreno, mesmo enquanto concepção, e isso favorece concepções mais 
globais, mais holísticas, visões mais integrantes. Tudo isso favorece determinados pensamentos e determinadas lógicas nesse processo: a lógica da intersetorialidade, a lógica do próprio sujeito, a lógica da participação, a lógica da responsabilidade. Então essas idéias todas, são campos que favorecem isso. Mesmo porque experimentos com ações muito fragmentadas, também, tiveram a oportunidade de serem feitas e como um todo, a sociedade teve a oportunidade de verificar quais foram os limites e quais foram as possibilidades dessas ações muito focais, muito fragmentadas."

A visão acima apresentada acrescenta elementos à discussão do capítulo introdutório deste estudo sobre a contemporaneidade e saúde.

No "começo do século" XXI, na Declaração do México, reconheceu-se, como cenário da saúde que: “Ao mesmo tempo, doenças novas e reemergentes ameaçam o progresso registrado na área da saúde. Há a necessidade urgente de abordar os determinantes económicos e ambientais da saúde, sendo preciso fortalecer os mecanismos de colaboração para a promoção da saúde em todos os setores e niveis da sociedade." 


\subsection{7- Carta de Fortaleza, 1995}

A Carta de Fortaleza é o primeiro documento produzido no Brasil que assume, explicitamente, como principal diretriz o conceito de promoção da saúde, tal como consta na Carta de Ottawa. Foi formulada no I Congresso de Secretários de Saúde das Américas, realizado, em Fortaleza, em outubro de 1995.

Em seu preâmbulo, renova os compromissos firmados em Alma-Ata (1978), Ottawa (1986) e Bogotá (1992), considerando-os "marcos referenciais de saúde para todos como direito fundamental do ser humano." (CONASEMS 2000)

Um dos entrevistados, refere-se à sua participação na organização deste evento, como o momento em que, como profissional, passou a conhecer o conceito de promoção da saúde. Várias pessoas, diz ele, estão no momento atuando no cenário brasileiro

L.A. "É uma história muito interessante. Vocé está pegando aí um fio importante, a história do CONASEMS [Conselho Nacional de Secretários Municipais de Saúde]. Como eu disse para você, junto com essa questão da Secretaria da Saúde e da Academia [Curso de Mestrado], houve a militáncia política no CONASEMS. Em 94 a gente estava em Quixadá. Em 93/94, o Raimundo Bezerra, o Secretário da Saúde de Fortaleza, foi aos Estados Unidos e voltou muito empolgado com essa possibilidade... Ele era também o presidente do CONASEMS. Raimundo Bezerra, como você sabe, foi Deputado Federal. Seu papel foi fundamental na criação do SUS, porque ele também foi Relator da Constituinte na área da saúde e da seguridade social. Raimundo 
Bezerra um cearense fantástico faleceu no ano passado de câncer de figado. Em 93 ele era Secretário da Saúde de Fortaleza, elegendo-se Presidente do CONASEMS. O Armando Ragio era o Vice. O Raimundo, então, se empolgou com essa história, com essa possibilidade, com a força do CONASEMS no Brasil. Decidiu, portanto, fazer um Congresso dos Secretários da Saúde das Américas. Queria fazer esse congresso em Fortaleza. Em 93/94, a Sônia Terra tinha acabado de chegar de Montreal, do Mestrado de Montreal, trazendo sua dissertação sobre Município Saudável. O Raimundo saiu, mas ficou aquela idéia de se fazer um encontro em Fortaleza. Foi quando o Gilson Catarino assumiu a Presidência do CONASEMS, em janeiro de 95, (...) Nessa época eu era Diretor de Relações Internacionais do CONASEMS. Coloquei o desafio para - Gilson Catarino, a respeito de realizar o congresso em Fortaleza. E aí, em contato com a Sónia, começamos a discutir essa questão da rede de municipio saudável. Nessa história toda a gente apoiou o congresso em Fortaleza. Fizemos uma viagem: eu, o Gilson Catarino, a Monica Zacharelli e a Sónia Terra. Na Venezuela tivemos contato com Lamis Maria Urbanez, Secretaria de Saúde de Caracas. Depois fomos a Nova lorque onde estivemos com o Dr. Mujika, Secretario da Saúde. Fomos à OPAS, em Washington e também tivemos um contato em Nova lorque com a UNICEF. Na OPAS e conversamos com vários diretores: na época, o João Yunes estava lá; outro brasileiro, Ostex e Helena Restrepo. Tivemos contato com essas pessoas... No Canadá, visitamos Quebec, Montreal, Ottawa e Toronto, conhecendo toda essa rede e convidando as pessoas para participarem do evento de Fortaleza, em outubro. Imagine só! Isso foi em agosto de 95 e o evento era em outubro!

D. E vocês conseguiram entrar na agenda dessa gente toda?

L.A. Conseguimos. Coisa de cearense mesmo, a maior cara de pau...(...) A gente conseguiu fazer uma movimentação. Conseguimos a participação de 15 países em Fortaleza. Nesse primeiro contato, tivemos uma pauta super 
interessante! Os Anais desse Congresso são fantásticos, tivemos muita discussão interessante...

D. Estes Anais estão no CONASEMS?

L.A. "Estão no CONASEMS! Eu tenho uma cópia e gostaria de publicizar isso. Foi a primeira vez que o CONASEMS assumiu essa discussão...(...) Foi muito rico nós estarmos discutindo isso, porque estávamos assumindo a descentralização, a gestão da saúde. Não tínhamos uma discussão acumulada em promoção da saúde. Os canadenses têm discussão acumulada sobre promoção da saúde, mas não têm na gestão. Foi uma experiência rica! Bancamos esse encontro. Tinhamos uns 800 participantes, uma delegação brasileira grande. O Ministro [da Saúde] Jatene passou dois dias em Fortaleza, - Governador Tasso foi à abertura, o Prefeito foi, o Presidente da Cámara, por sinal, na época, Presidente da Assembléia Legislativa é o meu prefeito hoje, o Cid Ferreira. Nasceu assim essa questão da Promoção da Saúde. A gente continua militando no CONASEMS. (...)"

Esta Declaração traz como propostas fortalecer os governos locais e resgatar o paradigma da saúde. Recomenda ainda que o CONASEMS coordene e garanta a continuidade de seus conteúdos.

Ao final desta análise dos documentos, ressalta-se que novas dimensões, além daquelas presentes nas Cartas ou Declarações aparecem associadas à promoção da saúde na fala dos entrevistados:

J.Y. "Então, todas as políticas que estamos elaborando, como por exemplo: de medicamento, alimentação e nutrição, prevenção, todas elas têm como eixo a promoção de saúde. Eu não vejo a promoção de saúde como um programa, eu vejo muito mais como uma doutrina, uma concepção, nosso marco teórico, 
que se aplica a todas as áreas. Portanto, as políticas que estamos elaborando leva em consideração o intersetorial, os estilos de vida, a política pública, a participação."

Para CARVALHO (1996) a promoção da saúde se constitui em um exemplo do "esforço de renovação conceitual, metodológica e prática do campo da saúde pública (...)". E, segundo ele, em Ottawa, "o conceito da promoção da saúde passa a ser considerado a espinha dorsal da nova saúde pública e é, pela primeira vez, definido em termos de políticas e estratégias."

A ampliação do debate a respeito das formas de operacionalização das propostas dos Documentos foi mostrada por GENTILE (2001) no estudo sobre Promoção da saúde e municipio saudável. Esta autora considera que: "a Promoção da Saúde, gestada no interior do movimento de ampliação da base conceitual da saúde, está baseada em três pilares básicos": o conceito de saúde como qualidade de vida, no caráter intersetorial das políticas e das ações, e na participação das pessoas, como sujeitos ativos nas definições destas politicas."

Segundo MINAYO, HARTZ e BUSS (2000): "Torna-se necessário investir muito ainda no aprofundamento do conceito e da mediação de promoção da saúde para que signifique mais do que uma idéia de senso comum, programa ideológico, imagem-objetivo e possa nortear o sentido verdadeiramente positivo de qualidade de vida."

\footnotetext{
Grifo no original.
} 


\subsection{Distinguindo Promoção de Educação em Saúde}

Ao longo do desenvolvimento desta pesquisa, buscou-se investigar se e como os entrevistados distinguem o conceito de educação em saúde do conceito de promoção da saúde.

A freqüente confusão entre Educação em Saúde e Promoção da Saúde e o conseqüente comprometimento teórico e técnico advindo deste fato têm merecido diversos estudos. (RAWSON 1992; CANDEIAS 1997; ROCHA 1997)

Para CANDEIAS (1997), as "confusões entre os termos educação em saúde e promoção em saúde tém provocado desentendimentos e afetado a qualidade de discussões técnicas que dizem respeito a intervenções sociais na área de saúde pública." Após diferenciar os dois conceitos, a partir das definições operacionais de GREEN e KREUTER, a referida autora se ocupa em caracterizar a natureza das distintas propostas de prática de saúde que estes originam. O que definiria a natureza da ação de educação em saúde seria o fato desta se constituir em "atividade-meio", uma vez que ela se ocupa principalmente "das atividades voltadas para a saúde, prendendo-se especificamente à habilidade de organizar logicamente o componente educativo dos programas." Para essa autora, as ações de promoção em saúde vão muito além "das pressões cotidianas do aqui e agora de programas de saúde pública". Com um enfoque mais amplo, pretendem provocar mudanças "organizacionais", que não se restringem à saúde individual e de pequenos grupos e que "assumem um caráter político muito mais intenso do que aquele que caracteriza a educação em saúde". 
De acordo com CANDEIAS, a educação em saúde diz respeito a uma prática que ocorre onde quer que haja atendimento à saúde nos niveis preventivo e curativo, como escolas, ambulatórios, sindicatos, hospitais etc. Diz respeito, portanto, à vivência cotidiana das pessoas, de uma forma mais próxima e direta, sendo, por isso mesmo, mais facilmente perceptivel, influenciando o comportamento individual e coletivo. Por outro lado, a promoção da saúde atuaria nos determinantes macro-estruturais (societais) que afetam o processo saúde/doença da população. Diz respeito, assim, a um conjunto de açōes políticas que visam a melhorar a condição de vida das pessoas. Isto inclui questões como moradia, trabalho, alimentação, educação, transporte, legislação, geral e especifica, e até questões de financiamento e alocação de recursos para os diversos setores da sociedade.

Ao analisar os depoimentos, verificou-se que, a maioria dos entrevistados distingue a educação da promoção da saúde, considerando que esta é mais ampla ou abrangente que aquela. Somente um entrevistado, que informou ainda não haver pensado sobre a diferença existente entre estes conceitos.

P.N. “Não atentei especificamente para isso. Acho que são coisas parecidas. A promoção estaria mais diretamente relacionada com a própria saúde, dentro do sistema de saúde. A Educação em Saúde, acho que é mais abrangente. Acho que ela está mais na raiz, a educação."

No âmbito teórico, a visão que predominou nos depoimentos é discutivel.(RAWSON 1992; WESTPHAL 1998a). Na visão de RAWSON (1992):

“A distinção entre educação em saúde e promoção da saúde tem, no entanto, sido tanto controversa quanto confusa. Recentemente algum consenso começa a emergir, redefinindo educação em saúde quase 
exclusivamente em termos de campanhas focadas individualmente, desenhadas para mudar estilos de vida. À medida que promoção da saúde ganha terreno, educação em saúde está, cada vez mais, enfrentando uma crise de legitimidade. Sempre que educação em saúde é identificada apenas com a tentativa de mudar estilos de vida individuais, também é considerada como um sinônimo de culpar a vítima. (...)

Considera-se importante destacar que nem todas as práticas educativas, que atuam visando mudanças de estilos de vida, se fundamentam em concepções de educação coercitivas, autoritárias (verticalizadas) e descontextualizadas (que culpabilizam as pessoas) Mas, ainda assim, dois entrevistados compartilham desta visão sobre a educação em saúde. Um deles até fundamenta seus argumentos reportando-se às caracteristicas e aos papéis atribuidos a esta prática nos primórdios da saúde pública.

D. Há diferenças de significado entre educação em saúde e promoção da saúde? Como estas se distiguem?

L.A. "Quilométrico, anos luz... Educação em saúde, isso é uma coisa higienista, que nasce nessa visão burguesa, na concepção higiênica. O higienismo nasce com o processo da burguesia. Inclusive, eu tive a oportunidade de observar isso quando era residente. Quando morava em Icapui, analisava a mortalidade infantil em algumas comunidades, convivendo com Colónias de Pescadores.(..) Dai vocé vé claramente como é a higiene, num processo que está ligado... Isso é um espaço urbano, processo da urbanização, essa coisa toda, que é uma coisa boa. Mas, a Educação em Saúde ela nasce nessa coisa, muito mais com espaço da pedagogia, do autoritarismo, a pedagogia da opressão. Ou seja, você tem um que sabe, o outro que não sabe. Eu era estudante de Medicina e observava isso, eu estava no quarto, quinto ano... Nas enfermarias que eu trabalhava de Obstetrícia, eu me lembro que uma bela manhã eu estava lá 
fazendo curativos das mães gestantes que tinham feito cesarianas. $E$, ai, entrou uma enfermeira com aquele álbum-seriado dando informação para as mães. que tinham que lavar as mãos, que tinham de comer verduras, que tinham que comer carne, que tinha que não sei o quê..... de prescrições higiênicas lá da Educação em Saúde clássica. Ai, quando ela sai, uma mãe vira pra mim. 'Doutor ela pensa que nós não sabe disso, a gente sabe isso tudinho Doutor. A gente não tem é dinheiro pra fazer essas coisas!' Isso para mim ficou muito forte, tirei grandes lições disso. Essa coisa de você estar atento aos detalhes. Eu estava no quinto ano da Faculdade. Hoje incorporei isso. Como Secretário, entendi que a Educação em Saúde é um componente que tem que ser bastante minimizado. Tem que estar junto de questões muito mais amplas, como a mobilização social, que é um conceito muito mais abrangente

Promoção da Saúde é muito mais abrangente. Eu diria que se a Promoção da Saúde é gênero a Educação e Saúde é uma Sub espécie, não é nem uma espécie é uma Sub da Sub da Sub espécie. Ou seja, uma coisa muito pequena frente ao conceito de Promoção da Saúde com o qual a gente trabalha. Quer dizer, não adianta você chegar e dizer que a pessoa tem que usar capacete. Tem que ter um conteúdo social, tem que ter uma mobilização social pra que as pessoas usem capacete, use cinto, que o adolescente não beba, que o cigarro... Tem que ter um conjunto. Não adianta ficar só no poder da polícia, polícia médica. A Educação em Saúde funciona muito na lógica da polícia médica.

Uma outra entrevistada foi veemente ao falar da diferença de significado entre os dois conceitos. Antes que a pesquisadora terminasse de formular a pergunta, esta já acenava com a cabeça, afirmando haver muita diferença. Estas diferenças são citadas no depoimento a seguir: 
D. Para você há diferença de significado entre a Educação em Saúde e Promoção da Saúde? [Acena que sim com um movimento de cabeça antes que eu termine de formular a pergunta]. Poderia falar um pouquinho?

S.F. "Há uma diferença muito grande. Acho que Educação em Saúde é uma coisa que diz respeito à mudança de comportamento, estilos de vida. Está mais ligada à questão da doença e da prevenção. Por exemplo: fumar. Você detecta que fumar é um problema, que causa determinados males e doenças e, por isso, você educa a pessoa para não fumar. A Promoção da Saúde está referenciada à saúde e não à doença. Ela não tem, vamos dizer assim, um objeto especifico, porque o objeto é subjetivo. Por quê? Porque cada pessoa vai sentir a saúde de um jeito. A Promoção trabalha com objetos subjetivos e isso é completamente diferente. Ela trabalha com o potencial da saúde enquanto a prevenção trabalha com a estabilidade da saúde. A educação trabalha no sentido da estabilidade - tome cuidado pra você não ficar doente! Enquanto a Promoção da Saúde trabalha com ser saudável e ser feliz. Ser feliz, sentir-se bem, cada um vai ter um parâmetro, e cada sociedade também. Se vocé leva isso para o coletivo, cada sociedade vai ter uma percepção. Se vocé pega as diferentes classes sociais brasileiras, são completamente distintas. Esse que é o desafio com que nós temos que trabalhar. Eu acho que nós ainda não incorporamos a questão cultural, antropológica, na Promoção da Saúde, no Brasil, Vai ser muito difícil, porque nós não vamos ter uma política única de promoção. Temos que ter propostas diferentes para cada grupo de individuos, comunidades, regiões. Enfim, é fascinante."

Analisando o depoimento acima, observa-se que a visão que a entrevistada tem sobre a Educação em Saúde se aproxima do entrevistado citado anteriormente. A educação em saúde é, então, concebida nos moldes da educação sanitária, que prevaleceu nas décadas. de 20 e 30 : médico-higienista. (CANDEIAS 1988, OSHIRO 1988). Porém, seus fundamentos são de outra 
natureza. Ela aponta para uma distinção de conceitos, tendo como pressuposto básico que estes se relacionam ou possuem objetos distintos.

Para outro entrevistado, citado a seguir, a distinção dos conceitos se dá mais no terreno do instrumental e das áreas de atuação.

E.M. "Isso é dificil. Eu andei tentando entender primeiro a educação em saúde e depois a promoção para saúde. Promoção da saúde, para mim, é esta nova prática, que envolve o conjunto das intervenções. É uma nova prática sanitária. Já, Educação em Saúde, não é uma prática com essa globalidade, holistica. Ela tem um campo comunicacional, um campo de ações educativas mesmo, enfim, das relações interpessoais, intergrupais. Eu acho que Educação em Saúde é menos que a Promoção da Saúde."

NAIDOO e WILLS (1996), ao discutirem sobre o desenvolvimento da educação em saúde e da promoção da saúde, concluem: "Nós adotamos a visão de que a educação em saúde é diferente em objetivo e método da promoção da saúde, mas faz parte do amplo processo de construção de políticas públicas saudáveis e busca da aceitação desta politica."

RAWSON (1992) considera que: "A maioria dos autores parece estar aceitando agora que Educação em Saúde seja redefinida como uma parte da perspectiva mais ampla de promoção da saúde."

WESTPHAL (1998a), ao pensar esta questão, considera que a educação continua sendo um recurso e componente fundamental de todas cinco estratégias de promoção da saúde da Carta de Ottawa. Vários entrevistados manifestaram a mesma visão, como se evidencia nos depoimentos abaixo:

P.B. "(...) educação é um componente importante da promoção, mas não é só educação; é educação, informação e comunicação- IEC. Claro que cada um vai 
conceituar de um jeito, mas na educação você está trabalhando com um enfoque de formar e informar individuos e comunidades em relação à sua posição no mundo; à sua posição consigo mesmo; o seu compromisso como cidadão; seu compromisso para incrementar a saúde etc. Não entendo que a educação trabalhe com elementos mais abrangentes, como a questão das políticas públicas saudáveis. Portanto, acho que Educação é uma parte muito importante da Promoção da Saúde."

No depoimento acima aparece a Informação como um componente ou uma estratégia da promoção. O entrevistado reporta-se ao valor que se atribui à informação ou à comunicação no conjunto das Cartas ou Declarações de promoção. Nestas, a informação favoreceria que: um maior número de individuos, de grupos e de comunidades despertasse para a necessidade de mudanças visando uma vida mais saudável; os direitos garantidos em lei fossem divulgados e reconhecidos pelos diferentes grupos populacionais, preparando-os para o exercício da cidadania e, ainda, introduzir a saúde, como uma importante dimensão da qualidade de vida, na agenda dos formuladores de politicas públicas.

PEREIRA LIMA et al (2000) consideram que: "Educação para a saúde e comunicação em saúde, como estratégias de promoção da saúde, possuem objetivos comuns (interfaces) e modos distintos e complementares de atuação, porém, é indubitável o papel da educação para a saúde para impulsionar uma participação efetiva, consciente, responsável e ética na vida social."

Outro entrevistado compartilha da visão das referidas autoras, como se observa a seguir:

A.V. "A Educação em Saúde é um componente da Promoção da Saúde. É uma das estratégias da Promoção da Saúde porque esta tem ámbito maior, tem um 
contexto muito maior de enfocar a saúde, no contexto social, político, econômico, assim como no desenvolvimento da pessoa. A Educação em Saúde apela para instrumentos de comunicação sobre a saúde. Ai há várias coisas que são necessárias e que se podem discutir: que a comunicação tem um contexto e que a forma como se dá a comunicação, no concreto, tem a ver com o contexto social e político. Isto faz com que a Educação em Saúde seja um componente muito importante da Promoção da Saúde, porque incorpora decisões como, digamos, a devolução da própria informação por parte de quem recebe; a participação, porque a participação tem de ser do tipo informal, não pode ser uma participação só de apoio, de apoio tutelado, tem que ser uma participação fundamentalmente consciente e que só se consegue através da Educação."

D: Há diferença para o Sr. entre o conceito de Promoção da Saúde e de Educação em Saúde?

V.P. “Há. A Promoção da Saúde, teoricamente, é um conceito muito mais amplo e, dentro dele, cabe a Educação em Saúde. Há quem diga que é exatamente o contrário, mas eu não acredito. Classicamente tínhamos uma divisão entre prevenção e educação. Essas coisas se aproximaram muito. Não há como o educador fazer só educação e o 'prevencionista' só aplicar métodos de prevenção. Os dois acabam trabalhando juntos. E a Promoção da Saúde junta classicamente estes dois conceitos. Junta em definitivo os conceitos de educação e prevenção. E junta mais toda a questão básica de orientação e organização de serviço e a relação com os outros setores que não a saúde. Então, a promoção de saúde, a meu ver, é um conceito mais amplo."

No depoimento abaixo, o entrevistado associa o conceito de Promoção da Saúde a uma visão de educação em saúde mais problematizadora. 
M.A. "Educar e promover. Acho que promover a saúde é despertar consciências; educar é mais informação, você informa as pessoas. Mas eu acho que, como eu vejo a questão da promoção hoje, a questão não é de informação. Na CASSI [Caixa de Assistência e Saúde dos Funcionários do Banco do Brasil] houve uma mesa redonda na semana do trabalhador para a qual eu sugeri um tema: ' $O$ fosso existente entre saber e fazer, cuidado para não cair no fosso e ser devorado pelos jacarés', porque a questão é um pouco essa. Hoje eu estava conversando com um pessoal que, provavelmente, há quatorze anos eu estou tentando fazer regime. Sei muita coisa no ponto de vista do meu estilo de vida e não mudo. Eu sei, estou informado, ninguém precisa me falar que não devo comer picanha gordurosa porque eu sei, mas é gostoso. Gosto de churrasco. Acho que não estou associando promoção com estilo de vida, mas é o que eu. Estou querendo dizer que tem haver com saber e fazer, nem sempre saber.. Acho que a educação em saúde informa. A promoção da saúde tenta, de alguma forma, despertar consciéncia de que a pessoa só pode mudar as atitudes se ela estiver consciente, bem consciente, bastante consciente. É coisa da alma, coisa sei lá, promoção é um pouco potencialidade, um pouco potencializar..."

Um entrevistado que, muitas vezes, ao longo do seu depoimento, se referia à Educação em Saúde falando de Promoção da Saúde também associou Promoção da Saúde a uma prática educativa mais contextualizada ou que considera os derteminantes sociais e culturais. Apontou outros "educandos" e "educadores", multiplicadores deste processo.

D. No seu depoimento você tem falado muito de Educação em Saúde. Você distingue Educação em Saúde de Promoção da Saúde?

P.C. "Não, não distingo não. Acho que a educação em saúde é uma estratégia para a Promoção da Saúde." 
D. Na verdade estão tratando da mesma coisa ou não. O que significa? Como você vè?

PC. "Acho que a Educação em Saúde... É gozado, porque ela participa de algumas técnicas, de alguns cursos. Mas os seus conteúdos devem ser os conteúdos de promoção, quer dizer, ser o discurso da promoção. Estranho para fazer um curso de Educação em Saúde, ensinar as pessoas a tomar banho ou, de alguém pegar determinadas doenças, não é? Você também não faz a menor referência sobre a influência do homem no meio ambiente e vice-versa. Você pode não introduzir esta discussão, esta reflexão. Acho que a Educação em Saúde é uma área que serve como desenvolvimento de tecnologias para a Promoção da Saúde. Para isso ela tem que recorrer aos conteúdos que a Promoção da Saúde traz, até na mudança de atitude politica do educador neste processo de educação. Quando você fala em Educação em Saúde, você tem que falar, também, de educação não-formal, ou seja, de re-educação de agentes que interagem neste processo. Ai vêm os prefeitos, vem não sei o quê! Eu acho que essas coisas não se misturam. Acho que não são sinônimos mas, essencialmente, não existem uma sem a outra."

Ainda que os dois últimos depoimentos não se refiram à Educação em Saúde, segundo a concepção higienista, prevalece a visão de que a educação em saúde é limitada, sendo associada à informação ou comunicação em saúde. Evidencia-se assim o desconhecimento, por parte de vários entrevistados, da existência de outros enfoques ou práticas de educação em saúde.

Pode-se questionar se a não distinção entre estes conceitos se deve ao fato da promoção da saúde ter se originado a partir da educação em saúde. $O$ relato de KICKBUSCH (1996) pode subsidiar a compreensão desta questão: 
"Esta evolução se produziu por muitos motivos, dos quais por hora me centrarei em dois. Em primeiro lugar, os educadores sanitários começaram a compreender a necessidade de aplicar enfoques positivos à promoção da saúde, incrementando a saúde, criando potenciais novos para a saúde no lugar de centrar-se somente na prevenção das enfermidades. Em segundo lugar, se fez evidente que a educação para a saúde só poderia desenvolver todas as suas capacidades apoiando-se em medidas estruturais (legais, ambientais, normativas, etc.) Se colocava a questão de como fazer que as escolhas mais saudáveis fossem, também, mais fáceis."

Ela continua, neste artigo, desenvolvendo a análise de como se deu este processo "evolutivo". Fica evidente que a crise de identidade da educação em saúde frente aos novos problemas colocados para a área e a necessidade de construir esta prática de forma mais participativa, impulsionou os educadores em saúde a buscarem referenciais e metodologias mais abrangentes

A compreensão deste processo, onde os educadores de saúde e seus escritórios se transformam, paulatinamente, em profissionais e espaços de promoção da saúde tem sido associado ao surgimento do movimento da "nova saúde pública".

No Brasil, com toda a diversidade, existem inúmeras propostas e práticas de educação em saúde. Além das açōes educativas desenvolvidas pelas organizações governamentais nos diferentes niveis (federal, estadual, municipal), segundo PEREIRA LIMA e RIBEIRO CAMPOS (1997), "se calcula que cerca de 5000 organizações não governamentais operam no país, com distintos niveis de funcionamento efetivo e de eficácia, com propostas de natureza social, em grande parte, relacionadas direta ou indiretamente à promoção e à educação em saúde." 
O surgimento de novos referenciais de educação em saúde, não significa que o referencial, até então vigente, deixou de existir. $\mathrm{Na}$ realidade, as diferentes concepções de educação em saúde coexistem na prática atual dos profissionais de saúde, como se evidenciou nos depoimentos analisados neste estudo.

A partir da análise da trajetória da educação em saúde e da promoção da saúde, observando os relatos dos participantes da pesquisa, identificou-se que muitos ainda não distinguem educação em saúde de promoção da saúde.

Uma das entrevistadas aponta um aspecto que cabe destacar aqui. Trata-se do "encolhimento" do espaço destinado às discussões de Educação em Saúde em função da expansão dos fóruns de discussão da Promoção da Saúde:

V.L. "(...) Eu noto que houve um certo ... Não sei se é uma impressão minha Houve um certo reducionismo da importância da educação em favor de uma grande preocupação com a promoção. Eu acho que a promoção é fundamental. Realmente, este envolvimento de todos os setores é fundamental, uma série de estratégias são muito importantes... (...) Embora a educação não se restrinja... Eu, pelo menos, não vejo a educação apenas como estratégia. A educação é mais que uma estratégia. Mas, eu acho que a educação é fundamental na capacitação das pessoas, no trabalho que você faz nas comunidades, no desenvolvimento das habilidades como a promoção ... Até mesmo na adesão das pessoas às propostas da promoção e, como, também, eu estou falando assim.... e estou contrariando o que eu penso... Porque eu acho que um grande trabalho, tem que ser um trabalho de baixo para cima, quer dizer, um trabalho com a sociedade. Eu dou ênfase enorme à educação. Eu não acredito nas propostas de cima para baixo apenas e acho que elas são sempre sujeitas a inúmeras pressões, as mais contraditórias." 
A entrevistada ao diferenciar promoção de educação em saúde expõe mais sobre a sua visão da educação do que, propriamente, sobre educação em saúde. Esta conexão pode ser melhor compreendida na citação abaixo, onde ela, em parceria com três outras reconhecidas estudiosas da área, afirma: " $A$ educação e a educação para a saúde possuem ampla área de intersecção: ambas têm como objetivo o desenvolvimento individual, a aquisição de autonomia e a preparação para o exercício da cidadania. A peculiaridade da educação para a saúde é orientar suas ações para melhorar a saúde e a qualidade de vida." (PEREIRA LIMA et al 2000)

A educação em saúde relacionada com o processo maior da educação se fundamenta em uma visão crítica do processo educativo, pois objetiva: "a transformação dos sistemas sociais, que só é possivel mediante a transformação dos seres humanos que o configuram. O homem é um ser em transformação e ao mesmo tempo, um agente transformador de sua realidade." (PELICIONI 1999) A educação em saúde, nesta visão, pode, então, viabilizar a participação das pessoas, de forma individual e coletiva, para lutar, por exemplo, por políticas públicas que possibilitem que, realmente, as escolhas saudáveis sejam as mais fáceis.

Concorda-se com a entrevistada, quando esta considera que o crescimento da promoção da saúde, no Brasil, tem se dado em detrimento ao da educação em saúde. No conjunto dos depoimentos, evidencia-se uma relação de oposição entre estes dois conceitos. Faz-se necessário resgatar que são práticas complementares, cada uma com a sua especificidade, instrumental e possibilidades de atuação. 
Quadro 4 - Distinção dos conceitos de educação em saúde e promoção da saúde, segundo a opinião dos entrevistados.

\begin{tabular}{|c|c|c|c|}
\hline & & Educação em Saúde & Promoção da Saúde \\
\hline & V.L & $\begin{array}{l}\text { "Eu a vejo como um trabalho } \\
\text { permanente, que deve acompanhar o ser } \\
\text { humano a vida toda. (..) E mais que uma } \\
\text { estratégia. E um processo permanente de } \\
\text { desenvolvimento pessoal, de ampliação } \\
\text { da consciência (individual e coletiva), da } \\
\text { realização pessoal, de aquisição de } \\
\text { autonomia." }\end{array}$ & $\begin{array}{l}\text { "No caso ou termos da promoção, eu vejo } \\
\text { muito mais uma visão politica do } \\
\text { funcionamento de tudo isso em favor das } \\
\text { pessoas. A Promoção da Saúde pensa a } \\
\text { questão da intersetonialidade, no } \\
\text { envolvimento de todos os setores da vida } \\
\text { pública, para que os prejuizos à saúde } \\
\text { sejam minimizados e esta saúde seja } \\
\text { respeitada. } \\
\text { (..) Acho que a promoção é um grande } \\
\text { guarda-chuva." }\end{array}$ \\
\hline $\begin{array}{l}\text { E } \\
\text { N } \\
T \\
\text { R } \\
\text { E } \\
\mathbf{V} \\
1 \\
\text { S } \\
\text { T } \\
\text { A } \\
D \\
D\end{array}$ & AV & $\begin{array}{l}\text { "É um componente da Promoção da } \\
\text { Saúde, uma estratégia. (..) A Educação } \\
\text { em Saúde coloca instrumentos de } \\
\text { comunicação sobre a saúde.(..). Isto faz } \\
\text { com que seja um componente muito } \\
\text { importante da Promoção da Saúde } \\
\text { porque incorpora decisões, digamos, a } \\
\text { devolução da própria informação por parte } \\
\text { de quem recebe; a participação, porque a } \\
\text { participação tem de ser do tpo informal, } \\
\text { não pode ser uma participação só de } \\
\text { apoio, de apoio tutelado, tem que ser } \\
\text { uma participação fundamentalmente } \\
\text { consciente eque se consegue através da } \\
\text { Educação." }\end{array}$ & $\begin{array}{l}\text { "Promoção da Saúde tem ámbito maior, } \\
\text { tem um contexto muito maior de enfocar a } \\
\text { saúde. A saúde no contexto social, } \\
\text { politico, económico e no desenvolvimento } \\
\text { da pessoa." }\end{array}$ \\
\hline & V.P. & Não identificado & $\begin{array}{l}\text { "A Promoção de Saúde, teoricamente, é } \\
\text { um conceito muito mais amplo, e dentro } \\
\text { dele cabe a educação para saúde. Há } \\
\text { quem diga que é exatamente o contráno, } \\
\text { mas eu não acredito. (...) A Promoção de } \\
\text { Saúde junta em definitivo os conceitos de } \\
\text { educação e prevenção. E, junta mais toda } \\
\text { a questão básica de orientação e } \\
\text { organização de serviço e, a relação com } \\
\text { os outros setores que não a saúde. Então, } \\
\text { a promoção de saúde ao meu ver é um } \\
\text { conceito mais amplo" }\end{array}$ \\
\hline & M.A & $\begin{array}{l}\text { "Educar é um pouco da informação, você } \\
\text { informa as pessoas.. Acho que a } \\
\text { educação em saúde informa." }\end{array}$ & $\begin{array}{l}\text { "Acho que promover saúde é despertar } \\
\text { consciências(...)Estou querendo dizerque } \\
\text { tem a ver com saber e fazer, nem sempre } \\
\text { saber... } \\
\text { (...)tenta de alguma forma despertar } \\
\text { consciência, que a pessoa só pode mudar } \\
\text { atitude se ela tiver consciente, bastante } \\
\text { consciente. É coisa da alma, coisa sei lá, } \\
\text { promoção é um pouco potencialidade, um } \\
\text { pouco potencializar..." }\end{array}$ \\
\hline
\end{tabular}




\begin{tabular}{|c|c|c|}
\hline I.C & $\begin{array}{l}\text { "A educação em saúde é um dos } \\
\text { instrumentos que a promoção como um } \\
\text { todo utilizaria. (..) educar e ter que } \\
\text { construir conceitos. }\end{array}$ & $\begin{array}{l}\text { "Ela incorpora, eminentemente, o conceito } \\
\text { de como construir mais saúde para } \\
\text { populações e sujeitos e a educação é só } \\
\text { um dos instrumentos." }\end{array}$ \\
\hline E.M & $\begin{array}{l}\text { "Já educação pra saúde eu acho que não } \\
\text { é uma prática com essa globalidade, } \\
\text { holistica. Ela tem um campo } \\
\text { comunicacional, um campo das ações } \\
\text { educativas mesmo, enfim, das relaçס̃es } \\
\text { interpessoais, intergrupais, certo? Então } \\
\text { eu acho que educação pra saúde é } \\
\text { menos que a promoção para a saúde." }\end{array}$ & $\begin{array}{l}\text { "Eu distingo porque promoção de saúde } \\
\text { para mim é esta nova prática, tá certo? } \\
\text { Que envolve muito, que envolve o } \\
\text { conjunto das intervenções, é uma nova } \\
\text { prática sanitária." }\end{array}$ \\
\hline L.A. & $\begin{array}{l}\text { "Educação em saúde, isso é uma coisa } \\
\text { higienista, que nasce nessa visão } \\
\text { burguesa, na concepção higiênica.(..) } \\
\text { Nasce mais como espaço da pedagogia, } \\
\text { pedagogia da opressão, do autoritarismo. } \\
\text { Ou seja de que você tem um que sabe e o } \\
\text { outro que não sabe. (..)funciona muito na } \\
\text { lógica da policia médica." } \\
\text { "A Educação em Saúde é um } \\
\text { componente, mas que tem que ser } \\
\text { bastante minimizado, tem que estar junto } \\
\text { de questôes muito mais amplas, muito } \\
\text { mais de mobilização social, acho que é } \\
\text { um conceito muito mais abrangente. }\end{array}$ & $\begin{array}{l}\text { "Então Promoção da Saúde é muito mais } \\
\text { abrangente, Promoção da Saúde eu diria } \\
\text { assim, se a Promoção da Saúde é género } \\
\text { a Educação e Saúde é uma Sub espécie, } \\
\text { não é nem uma espécie é uma Sub da } \\
\text { Sub da Sub espécie, ou seja, uma coisa } \\
\text { muito pequena frente ao conceito de } \\
\text { Promoção da Saúde que a gente } \\
\text { trabalha." }\end{array}$ \\
\hline J.Y. & $\begin{array}{l}\text { "A educação em saúde e a comunicação } \\
\text { social são dois pilares fundamentais na } \\
\text { promoção de saúde, mas não são } \\
\text { sinónimos.(...) é um pilar importante." }\end{array}$ & Não identificado \\
\hline P.B. & $\begin{array}{l}\text { "E um componente importante da } \\
\text { promoção, mas não só a educação. É } \\
\text { educação, informação e comunicação - } \\
\text { IEC....)não entendo que a educação } \\
\text { trabalhe com esses outros elementos } \\
\text { mais abrangentes como a questão das } \\
\text { políticas públicas saudáveis. Portanto, } \\
\text { acho que educação é uma parte da } \\
\text { promoção de saúde muito importante." }\end{array}$ & Não identificado \\
\hline S.F. & $\begin{array}{l}\text { "Acho que Educação em Saúde é uma } \\
\text { coisa de mudança de comportamento, de } \\
\text { estilos de vida, que está mais ligado a } \\
\text { questão da doença e da prevenção.(...) } \\
\text { E a educação trabalha no sentido da } \\
\text { estabilidade - tome cuidado pra você não } \\
\text { ficar doente." }\end{array}$ & $\begin{array}{l}\text { "Está referenciada à saúde e não a } \\
\text { doença. Ela não tem, vamos dizer assim, } \\
\text { um objeto especifico, porque o objeto é } \\
\text { subjetivo. Porque cada pessoa vai sentira } \\
\text { saúde de um jeito. Então, a Promoção } \\
\text { trabalha com objetos subjetivos e isso } \\
\text { muda, é completamente diferente. Ela } \\
\text { trabalha o potencial da saúde(...)." }\end{array}$ \\
\hline P.N & $\begin{array}{l}\text { "A educação em saúde, acho que, é mais } \\
\text { abrangente e terminaria promovendo a } \\
\text { saúde. Acho que ela está mais na raiz." }\end{array}$ & $\begin{array}{l}\text { "A promoção da saúde seria assim mais } \\
\text { direta com a própria saúde, dentro do } \\
\text { sistema de saúde, sobre como se } \\
\text { promover a saúde." }\end{array}$ \\
\hline
\end{tabular}




\section{ELEMENTOS QUE FAVORECERAM A ENTRADA DA PROMOÇÃO DA SAÚDE, NO BRASIL, NA DÉCADA DE 90}

Busca-se, neste item, apreender que ideário ou valores, segundo os entrevistados, configurou o cenário brasileiro, para acolher a promoção da saúde, na década de 90 . Ou, dito de outra forma, que interesses ou agendas estavam postos para a saúde pública brasileira e que propiciaram o interesse pela promoção da saúde (questão 4).

A partir dos depoimentos dos entrevistados, foi possivel identificar elementos que favoreceram a entrada ou a receptividade do referencial da promoção da saúde, na realidade brasileira. Estes foram de duas naturezas: uma diz respeito ao ideário ou concepções vigentes ou em construção no Brasil, que aproximou, teve afinidade ou acolheu os valores ou idéias da promoção da saúde; a outra se relaciona com fatos históricos, que propiciaram condiçōes institucionais, legais, financeiras, entre outras, para a entrada da promoção da saúde.

A maioria dos entrevistados considerou que o movimento sanitário, a Reforma Sanitária e o processo de implementação do Sistema Único de Saúde (SUS) configurou um determinado cenário político-ideológico e estrutural para a entrada e recepção da promoção da saúde, no Brasil.

Não é pretensão deste estudo realizar uma discussão aprofundada sobre o processo de construção do SUS, desde as suas origens. Este tem sido objeto de muitas pesquisas, eventos e publicações há mais de duas décadas, na saúde pública brasileira. Na verdade, pode-se afirmar que, é difícil encontrar 
uma dissertação ou tese da área que não introduza algum aspecto ou que não mencione a Reforma Sanitária Brasileira, da década de 80.

Interessou analisar, nesse processo, as conexões que os entrevistados estabeleceram com a promoção da saúde. Inicia-se essa discussão exemplificando com o depoimento de um dos entrevistados, que tem difundido esta visão em publicações (BUSS 2000; BUSS 1998), conferências em eventos e em cursos de pós-graduação:

P.B. "Se você ler a Carta de Otawa e ler o Relatório da Conferência é impressionante as identidades que se encontram ali. Então, eu costumo dizer que as duas aconteceram em 86. A Carta de Otawa, para mim, é o panfleto, a carta de principios da promoção de saúde dos industrializados. E, no Brasil, não vou falar da América Latina, nós temos nossa "Carta da Promoção", sem esse nome, que é a VIII Conferência Nacional de Saúde e seu relatório final. Ela coloca a determinação múltipla do processo de saúde /doença; essa idéia da intersetorialidade na resposta; a participação social, só que ela ainda tem o modelo, quer dizer, o modelo que ela propõe é ainda um modelo do sistema de saúde. Quer dizer, ela não consegue construir as outras pontes.

Muito bem. A lei, a seguir, nós vamos, os sanitaristas brasileiros, membros desse chamado "movimento da reforma sanitária", trabalhar na construção da Constituinte. Quer dizer, foi criada a Plenária Nacional da Saúde para a Constituinte. Isso está bem descrito por Eleutério Rodriguez Neto e mais algumas teses que foram feitas.

Todo esse processo, ele redundou em uma Constituição Federal de 88 e, dois anos depois, em uma lei Nacional de Saúde, a lei do SUS 8080 e 8142 . Nesse período da segunda metade da década de 80 , que você tem, nitidamente ali, a lei então, chega a ser escandalosamente promocional. Quando você lê um artigo $3^{\circ} \mathrm{da}$ lei 8080 , que fala assim (não tem nada a ver, não é um texto legal) a saúde é determinada por fatores. Ai bota assim, que nem os recursos 
fundamentais para a saúde da Carta de Otawa, os pré-requisitos, coloca habitação... É impressionante! $E$ as pessoas não tinham acesso, não sei. Eu não me lembro, eu não tinha acesso à Carta de Otawa e nunca se colocava a questão da Carta de Otawa, entendeu? Então, é uma coisa que, ou secretamente alguém tinha... mas não é isso!..

D. Uma das pessoas da minha banca de qualificação colocou isso. Questionou a partir do fato de que depois é que se viu a influência da reforma italiana na nossa reforma.

\section{P.B. Com certeza...}

D. Será que alguns não tinham acesso à discussão de Ottawa?

P.B. Acho que sim... Mas veja, eu participei. Desde 75 eu participo dessa história. Toda discussão que chegou na Conferência, que foi de 75 a 86, ela nunca menciona a Carta de Otawa. Tem uma formulação genuinamente nacional. Quer dizer que, em 74 tem o Informe Lalonde. Tem a tese do Arouca de 75. O campo da saúde, com aquelas quatro dimensóes, não é trabalhado com essa configuração em nenhum momento. Então, simplesmente, eu acho que é a realidade fantástica da América Latina como, também, a do Brasil: gera tantos problemas, quanto gera capacidade de respostas dos seus intelectuais engajados politicamente. Eu acho que é o caso desse grupo do movimento sanitário.

Então, na segunda metade da década de 80 , você tem isso, a lei 8080 e a lei 8142 que é complementar. Ela é uma concessão do Collor [Presidente da Repúblical à enorme pressão, porque ele tinha cortado tudo o que era participação social dos conselhos de saúde. Na 8142 ele é obrigado a aceitar novamente os conselhos de saúde. E o que são os conselhos de saúde? 
Paritários e dos dois lados - tanto da representação popular quanto da representação governamental - são multisetoriais.(....)"

Inicialmente, evidencia-se que, a exemplo deste entrevistado, vários outros participantes da pesquisa relataram terem militado no movimento sanitário. Muitos se emocionaram ao narrarem as estratégias adotadas, as articulações político-partidárias, as idéias defendidas e as participações que tiveram nos eventos.

RODRIGUEZ NETO (1998), um dos autores referidos no depoimento anteriormente apresentado, distingue movimento sanitário de Reforma Sanitária. Segundo esse autor, movimento sanitário foi um movimento, inicialmente, composto por profissionais de fora e dentro das instituições oficiais de saúde, que "foi-se ampliando, incorporando parlamentares, lideranças politicas, sindicais e populares, promovendo debates e divulgando suas idéias.(...) Caracterizou-se por não apenas fazer denúncias contra a ditadura e os interesses económicos com ela envolvidos, mas, também, por apresentar propostas construtivas, apresentando como alternativa um projeto de transformação do sistema de saúde vigente." Já, a Reforma Sanitária seria "a proposta para a democratização da saúde" ou o projeto que continha as recomendações do Relatório da VIII Conferência e que "foi levado à Assembléia Nacional Constituinte em 1987, para disputar com outras propostas o que seria escrito na Constituição sobre a Saúde". Para o referido autor, as principais propostas do projeto ou da Reforma Sanitária foram: "o conceito ampliado de Saúde que foi consagrado na Constituição de 1988 e a garantia da "Saúde como direito de cidadania e responsabilidade do Estado."

Segundo ESCOREL (1998): "Vê-se a formação do movimento sanitário como uma articulação de pessoas e grupos que, no momento da realização da 
VIII Conferência Nacional de Saúde, apresentava tendências crescentes de ampliação tanto em número de integrantes quanto no campo da atuação."

Buscando caracterizar este movimento, ESCOREL (1998) analisou o ideário deste. Para ela, o movimento sanitário se fundamentou no discurso médico-social. A configuração deste discurso foi objeto da tese de doutoramento de Sérgio Arouca, em 1975, citada anteriormente pelo entrevistado

Alguns dos principais elementos do discurso médico-social destacados no texto de ESCOREL - sistemas e políticas de saúde são o seu objeto; saúde-doença como processo social, historicidade do processo e determinação social são os conceitos básicos; politização, socialização, participação, universalização, regionalização, hierarquização e descentralização são as proposições - são citados pela maioria dos entrevistados participantes deste estudo como tendo afinidade ou similaridade com o referencial da promoção da saúde.

P.N. "Essa noção das diferenças, das desigualdades, dos fatos geradores da doença, o qué é que realmente... Se a gente for fazer uma história clínica da doença atual e todos os seus antecedentes... Mas quando a gente abre isso pra visão social, de que é maior. Essa história vai agregando essas outras noções bem maiores."

P.C. "Acho que o ponto fundamental, que impulsionou este discurso da Promoção da Saúde e as práticas da Promoção da Saúde, foi a mudança da Constituição.(...) No Brasil, acho que é a conseqüência da legislação do SUS. O SUS, ao incorporar o controle social, que ainda funciona de forma, não incipiente, mas é uma forma ainda em desenvolvimento, diriamos assim. Ele 
criou estas condições institucionais para que a área da Promoção da Saúde ganhasse mais espaço no sentido de investigar as reais causas das condições de saúde das pessoas, da qualidade de vida e tal. Isto fez, de um lado, que o próprio movimento popular assumisse esta agenda com mais clareza e daí derivasse que a percepção caminha, neste sentido mais amplo de determinação da saúde e da doença é... como causa social, espaço social que isto pode ser observado. $E$, de outro lado, o movimento que os próprios dirigentes fazem para se organizar, para que ao assumirem o SUS, assumissem novas políticas. Antes do SUS, antes da Constituição de 1988, você tinha que sensibilizar o Ministro, o Secretário de Estado, que eram os órgãos onde concentravam o maior poder de determinação das políticas. Hoje, você tem os prefeitos, que estão mais autônomos em relação a isto. Portanto, se vocé tinha antes 20 e tantos governadores e um ministro para sensibilizar, 0 que parecia muito mais fácil porque é menos gente, mas o alcance é muito maior, eles se movem com muito mais dificuldade, acesso. Já, o prefeito vocé tem um acesso direto, com uma variedade e com um perfil muito grande. Vocé consegue desenvolver estratégias e projetos e focos de desenvolvimento desta política com muito mais intensidade, e é o que aconteceu. Acabou influenciando o próprio fórum deles. O Conselho de Secretários Estaduais, o congresso deles."

Muitos dos conceitos básicos e proposições identificados neste movimento, que estavam sendo veiculados, no final da década de 80 e início de 90, foram citados pelos entrevistados. Eles estão, também, presentes nos documentos da promoção da saúde deste periodo.

L.A. “Acho que tem alguns fatores que são favoráveis. Eu acho que a primeira coisa é que os principios norteadores da Reforma Sanitária coincidem com um dos princípios da Promoção da Saúde. O próprio fato da Reforma Sanitária ser 
um ator político forte, que passa a ter uma reflexão conjunta, que imprimiu a organização dos sistemas municipais de saúde. Então, essa convergência dos princípios da Reforma Sanitária e da Promoção da Saúde além do fortalecimento do sistemas locais e municipais de saúde, é um espaço que tem sido, digamos, um fator importante dessa apropriação. $E$ esse espaço internacional de construção, de discussão. A outra coisa, também, é a crise do setor saúde, essa crise paradigmática, essa crise mesmo, esse limitante. Ou seja, o fato cada vez ficar mais evidente de que as questões da saúde também estão fora da saúde. Então isso tem sido... No município dá muita visibilidade pra você ver isso."

No depoimento acima, o entrevistado além de apontar a convergência de valores da Reforma com os da Promoção da Saúde, reconhece, também, a influência, no Brasil, da discussão internacional sobre a promoção da saúde.

E.M. "Eu acho que primeiro o conceito que vinha sendo discutido muito no chamado movimento sanitário também. Por outro lado, você tem uma discussão no movimento sanitário muito influenciada pelo Partido Comunista Italiano, pelos escritos do Berlinguer. Porque o movimento sanitário brasileiro surge da Reforma Italiana, que é uma reforma dos anos 70, que é a reforma, basicamente, construida ideologicamente pelos comunistas italianos da época $e$ mediada no Brasil pelo Partido Comunista Brasileiro (PCB). A importância do Arouca, do Partidão. Em todo o movimento da reforma. Isto e do Berlinguer que vinha, freqüentemente, ao Brasil. E, com esta coisa do conceito ampliado de saúde, que acabaram por colocar na Constituição. Saúde não é só, mas é.... uma série de coisas mais, e isso entrou na nossa Constituição por força desse movimento sanitário mediado pelo "Partidão".

A influência internacional e a visão de "partidarização" do movimento sanitário acima manifestada também foi objeto de estudo de ESCOREL (1998). 
Esta autora, a partir da observação deste processo, defende que: "a conformação do movimento sanitário ocorreu através da experiência plural das oposições. A convivência das diferentes correntes de pensamento, ainda que nessa conjuntura com uma direção nitidamente vinculada ao $P C B$, foi o que permitiu sua consolidação. (...)"

A seguir, mais uma vez, se reconhece as afinidades conceitual e temporal da VIII Conferência e da Carta de Ottawa:

AV. "Acho que o Brasil tem uma longa trajetória, principalmente, nos aspectos de incorporação do controle social dentro do Sistema Único de Saúde. Acho que vocês têm uma data histórica, que é 1986, quando fazem aquela Conferência de Saúde, onde colocam que a saúde não é só ausência de doenças e que para ter saúde se necessita moradia, lazer, educação, trabalho etc. Tudo inclusive muito paralelo com o que se estava produzindo na Carta de Ottawa.

D. É, são os pré-requisitos colocados na Carta..

AV. Então, acho que, inclusive temporalmente, o Brasil estava um pouco mais adiante.

D. Aqui em março e lá em novembro...

AV. E com isso, acho que no contexto dos paises latino-americanos, o Brasil tem esta vantagem. Ele iniciou o processo muito mais rápido. Haver realizado esta conferência que produz aquele conceito maior de saúde e que permitiu que no interior do mundo acadêmico, como no mundo dos serviços de saúde e movimentos sociais pela saúde venham colocando a saúde com um outro 
enfoque. Não com foco nos serviços de saúde senão como uma responsabilidade de todos."

O diálogo acima dirime a dúvida levantada no primeiro depoimento citado neste tópico, sobre a possibilidade dos militantes do movimento sanitário terem tido um contato com a Carta de Ottawa, previamente à realização do Relatório da VIII Conferência de Saúde. Analisando o conjunto dos depoimentos, evidencia-se que as primeiras leituras do referencial da promoção que os entrevistados fizeram datam do início da década de 90 . Nenhum deles citou ter lido o Informe Lalonde.

Foram citados, por um dos entrevistados, alguns conceitos que o sensibilizaram ou que o desafiaram a operacionalizar a promoção da saúde na realidade brasileira. Os conceitos foram grifados no trecho a seguir:

J.Y. "Os valores, eu considero que é realmente qualidade de vida. A gente não consegue qualidade de vida olhando através só de um setor.Mas este conceito de envolver outros setores e, também, o conceito de politica pública, que são políticas que nascem de outros setores e que têm repercussão na saúde. Estes são valores assim que me marcaram muito em termos de tentar materializar este conceito. Traduzir em ações concretas."

As duas entrevistadas desta pesquisa consideraram que, no Brasil, no início da década de 90, o referencial da promoção da saúde não foi "acolhido" ou não teve ressonância porque os interesses aqui estavam voltados para a implementação das propostas da Reforma Sanitária, ou melhor, para a implantação do SUS. Portanto, os dois depoimentos a seguir divergem, em alguns aspectos, da opinião dos demais entrevistados: 
V.L. "Quando houve este Seminário [Diagnóstico Nacional das Ações de Educação em Saúde no Brasil] nós convidamos a Maria Tereza Cerqueira da OPAS, que tem tido um contato muito estreito com o Brasil e com a FSPIUSP. E. Maria Tereza fez uma primeira conferência... Acho que foi a conferência de abertura sobre promoção da saúde. Em função desta presença e deste conteúdo, nós programamos, também, um trabalho de grupo sobre Promoção em Saúde, que aconteceu durante todos os dias do seminário.

Como as pessoas viam esta proposta? Naquela ocasião, em 1990, não houve uma ressonância tão grande porque era um assunto que ainda não estava na pauta dos debates aqui. Eu até tenho uma interpretação para isto. Eu acho que o Brasil viveu, nesta área, no setor saúde, um processo, uma conquista muito importante com a Reforma Sanitária. A VIII Conferência Nacional de Saúde foi uma Conferéncia muito interessante porque foi precedida de um amplo debate. Foi altamente democrática, com a presença dos grupos mais representativos. (...)De repente se definiu uma série de prioridades, com aqueles temas da Conferência e as conclusões da Conferência, inclusive, vieram subsidiar o texto Constitucional. Então, eu acho que tudo foi debatido, todas as grandes propostas relacionadas a um Plano Nacional de Saúde atento à universalização, ao controle social. Todas estas conquistas foram de tamanha importância que elas representaram para nós, realmente, a grande conquista, o grande passo. E nelas estão embutidas muitas das preocupações da promoção da saúde. Quer dizer, esta ênfase nas condições de vida, no trabalho multiprofissional... Todas as questões estavam muito próximas desta grande mudança. Quer dizer, a nossa Conferência Nacional foi, mais ou menos, na mesma época da Conferéncia do Canadá - de Ottawa. Eu acho que esta Carta de Ottawa não teve, de imediato, a repercussão que poderia ter tido aqui em função deste grande passo que nós haviamos dado, por nossa própria conta, e que estava absolutamente adequado à nossa realidade, às nossas experiências, aos nossos anseios. 
Até 1990, não havia esta preocupação tão grande com a questão da promoção. E, a questão da promoção, eu acho que foi trazida meio assim de fora para dentro mesmo. As pessoas pararam para tomar conhecimento, para debater, para digerir a proposta da promoção. (...)"

CERQUEIRA (1997) avalia que "tanto o marco conceitual como a prática da promoção da saúde têm-se desenvolvido mais na Europa Ocidental, Canadá e Estados Unidos da América. Na América Latina e no Caribe o avanço tem sido lento e com algumas resistências por parte dos trabalhadores da saúde." Não esclareceu, contudo, em que fatos ou critérios se baseia para fazer tal avaliação. Qual seria o crescimento esperado? Por que os profissionais da América Latina e Caribe não têm se "seduzido" pelo movimento da promoção da saúde? Será que eles não a consideram pertinente para a nossa realidade? Ou estariam eles vinculados a outro projeto (idealizado ou em construção), sem afinidade com o proposto pela OPAS/OMS: "têm desempenhado um papel fundamental no fomento e adoção da promoção em saúde como estratégia de saúde pública com os governos e membros na região das Américas."? (CERQUEIRA 1997)

O depoimento de V.L. pode dar pistas da origem deste pensamento de CERQUEIRA (1997). Há divergência de opiniōes entre os entrevistados quanto ao ritmo da difusão da promoção da saúde, no Brasil, conforme analisado neste estudo. A referida autora pode compartilhar a opinião dos que esperavam que o referencial da promoção da saúde estivesse mais difundido e sendo, portanto, implementado mais rapidamente, na realidade brasileira.

Nos depoimentos a seguir são apresentados outros elementos para pensar os fatores que determinaram, na década de 90 , a repercussão do referencial da promoção da saúde. 
S.F. "(...)Eu, quando voltei com essa Tese, acho que foi em 93, procurei o pessoal da OPAS e as portas estavam fechadas, porque eles achavam que não, que esse negócio de cidade saudável... Primeiro porque era um slogan, e outro que não, que era uma coisa muito adiantada, que isso era coisa de países ricos, que o Brasil não estava preparado... Eu ouvi coisas incriveis de resisténcia à proposta, isso em 93. Então eu achei que eu ia...(...)"

Evidencia-se que até mesmo a OPAS, nos primeiros anos da década analisada, não estava apostando ou investindo tanto nesta difusão. Pode-se questionar, também, que talvez não associassem a idéia de "Cidade Saudável" aos referenciais da promoção. Ou, ainda, que este conceito não tenha sido identificado como algo que pudesse favorecer ou constituir uma estratégia para a operacionalização das proposições da promoção da saúde. Concepção esta manifestada, na atualidade, por vários dos participantes deste estudo.

D. Do seu ponto de vista que idéias ou valores têm propiciado o interesse pela Promoção da Saúde no Brasil?

S.F. "Que novos valores?"

D. Não, que valores propiciam, ideários que estão vigendo no Brasil, que propiciam espaço para Promoção da Saúde? Você chega em 93 com a idéia da Cidade Saudável, não era muito o termo... Orgãos como a OPAS te falam ainda não é o momento, isso é para lá... Depois, agora, no momento, a Promoção da Saúde é veiculada no Brasil, o que vocè acha?

S.F. "Eu acho que nós temos que... É um processo porque, por exemplo, em 93, no final da década de 80 , início da década de 90 , é a coisa da estruturação do SUS. O esforço todo, a questão, a Saúde Pública se voltou muito... Eu diria até que se institucionalizou muito, em termos das normas de implantação. $A$ 
partir da Constituinte, então, houve um esforço de normatização do sistema. Houve uma institucionalização das propostas e perdeu-se a dimensão política, a dimensão da necessidade, da vitalidade da sociedade, da participação Depois ficou muito em termos da questão do controle social, da estruturação dos conselhos, muito institucionalizado. Acho que agora o que nós temos é um esgotamento das possibilidades das reformas, entendeu? $E$ pelo contexto politico, que as normas, elas passam a ter um caráter restritivo face ao contexto económico de crise. Então a crise, a recessão faz com que os cortes... Vamos ter que cortar, então as normas vão no sentido dos cortes e não vão no sentido de normatizar, como diz o Gilson Carvalho: 'A ousadia de fazer cumprir a lei'.

Então não é normatizar o que está na Lei Orgânica da Saúde. Nós estamos normalizando em função da crise, do contexto de recessão econômica. Então, eu acho que esse paradoxo, esse limite, faz com que haja uma espécie de um alerta, uma tomada de consciência, de que é preciso recuperar. Quando eu digo recuperar significa recuperar o paradigma da saúde, porque a gente sempre foi, a gente sempre teve as reformas na lógica da saúde não da doença. Mas, os limites da reforma estão nos limites desse modelo biomédico, clínico, tecnológico.

D. Voltado para essa discussão primeira da mudança do modelo de atenção...

S.F. Exatamente. Eu nem diria modelo, nem mudança de modelo porque eu não gosto essa coisa de modelo não. Eu acho que nós não vamos criar um modelo. A gente fica procurando modelos. Eu acho que nós temos que criar algo genuíno, algo próprio, algo brasileiro porque nós somos um país multicultural, multifacetado. A medicina tradicional ela é completamente, vamos dizer assim, rechaçada ainda, quer dizer há uma tentativa de, por exemplo: a fitoterapia...

D. As medicinas ditas complementares por alguns, alternativas, por outros... 
S.F. Eu chamo de Medicina Tradicional, o Saber Tradicional, o Saber Popular. Eu acho que nós precisamos pensar nisso em termos de uma constituição, de uma humanização, de um sistema que contemple. Eu falo sempre para o pessoal daqui do CONASEMS: nós precisamos olhar muito a China, a índia. Apesar de na índia ainda ser muito caótico, mas a coisa do Saber Popular. Nós ainda estamos muito longe e eu acho que nós precisamos aproximar, pra criar uma assisténcia que tenha uma legitimidade dentro do Saber Popular. Que vai ser mais humanizado no ponto de vista, isso no termo da assistência. Em termo da Promoção é obvio o que está se evidenciando, é que nós temos que recuperar a nossa vitalidade politica, que nós não podemos ir a reboque das normas, das portarias e das..."

A entrevistada, concordando com quase todos os demais participantes deste estudo, também, reconhece a afinidade dos principios da Reforma com os da promoção da saúde. No entanto, ela aponta dois fatores que determinaram que o interesse da saúde pública pelo referencial da promoção se manifeste somente agora.

O primeiro fator se relaciona com o que a autora chama de "esgotamento das possibilidades das reformas". Este tema tem sido discutido, na atualidade, em vários fóruns e estudos. Existe uma discussão de que as possibilidades da Reforma tinham como horizonte a construção do SUS, portanto, foi pensado e concebido até o desenvolvimento jurídico-organizacional deste sistema. Não pretende-se adentrar nesta polèmica e acalorada temática.

O segundo fator sinalizado pela entrevistada fala do contexto de crise financeira no qual vive o setor saúde e que impulsiona a busca de outras alternativas. A discussão do financiamento do setor saúde e das demais políticas sociais, no Brasil, e demais paises em desenvolvimento, também, 
emerge no depoimento dos outros entrevistados quando opinam sobre quais os setores seriam responsáveis pela implementação das ações de promoção da saúde.

Ao final, destaca-se, ainda, no depoimento acima analisado, a visão apresentada sobre a necessidade do referencial da promoção da saúde e outras propostas convergentes serem discutidas à luz das diversidades e peculiaridades das realidades brasileiras. Combate-se, assim, a importação acrítica de "modelos" pensados e testados em outras realidades. 
Quadro 5 - Valores ou idéias que favoreceram a entrada do referencial da Promoção da Saúde, na realidade brasileira, segundo opinião dos entrevistados

\begin{tabular}{|c|l|}
\hline Entrevistado & \\
\hline P.C. & \multirow{2}{|c|}{ Valores ou Idéias } \\
\hline P.B. & Determinação múltipla do processo saúde-doença \\
Conceito ampliado de saúde: resultado das condições concretas de vida \\
presente no ideário do movimento sanitário.
\end{tabular}

Quadro 6 - Fatos históricos que favoreceram a entrada do referencial da Promoção da Saúde, na realidade brasileira, segundo opinião dos entrevistados.

\begin{tabular}{|c|l|}
\hline Entrevistado & \multicolumn{1}{|c|}{ Fatos Históricos } \\
\hline $\begin{array}{c}\text { A.V. } \\
\text { P.B. }\end{array}$ & VIII Conferéncia Nacional de Saúde \\
\hline P.B. & Publicação e defesa da tese do Arouca em 1975. \\
\hline P.B. & Movimento da Reforma Sanitária ou Movimento Sanitário \\
\hline P.C. & Mudança Constitucional de 1988 \\
\hline E.M. & Legislação do SUS \\
\hline P.C. & Estruturação ou institucionalização do SUS \\
\cline { 2 - 2 } & Contexto económico de crise \\
\hline
\end{tabular}




\section{ESTRATÉGIAS DE DIFUSÃO DA PROMOÇÃO DA SAÚDE NO BRASIL}

Os entrevistados reconheceram que tem havido uma difusão da promoção da saúde no Brasil, na década de 90 . Mas, eles divergiram em alguns aspectos quanto ao ritmo e conteúdo desta difusão.

Para dois deles - um que fala enquanto Representante da OPAS, no Brasil e outro enquanto Prefeito e coordenador da Rede Brasileira de Municípios Saudáveis -, o ritmo ou o crescimento da promoção da saúde no Brasil ainda está muito lento, ou melhor, aquém do desejado.

Em relação a este "esperado" crescimento, obteve-se a seguinte resposta:

D. "O Senhor considera que tem havido uma difusão da Promoção da Saúde no Brasil?

P.N. Não tanto como deveria ser, isso era pra ser mais discutido, mais comunicado, fazer com que as pessoas compreendessem melhor a própria mudança de rumo. As televisões e rádios mostram filas no hospital, gente sendo atendido em maca. Mas, aquilo é um buraco de uma fechadura de um sistema enorme, que aquilo ali existe exatamente pelo mau dos hospitais, que poderiam estar bem menos sobrecarregados se essas coisas que evitassem isso dai... 
D. Dentro dessa difusão, mesmo não sendo da quantidade que o Senhor esperaria, ela está com mais espaço? Quais seriam as principais estratégias que têm sido adotadas para essa difusão? O que é que o Sr. tem identificado?

P.N. Lá na minha região, ou como um todo?

D:Como um todo, no Brasil.

P.N. Eu vejo muito pouco, acho que esse conhecimento ele tá muito restrito a técnicos, a algumas pessoas que conhecem bem o sistema. Esses encontros que a gente vai tá todo mundo... Mas, eu não acho que o sistema...

(....)Nós estamos sabemos disso aqui, o Ministério tá sabendo disso, alguns Secretários Municipais estão sabendo disso. Mas, vá lá na rua, num bairrozinho, entre na casinha lá, sente num banquinho e pergunte: 'Você sabe o que é Promoção de Saúde?' Ela vai pensar que é uma venda, uma promoção, que tem um desconto, digamos assim...".

Na expectativa deste, a difusão já deveria ter conseguido alterar a visão do senso comum sobre promoção da saúde. A própria imagem do Sistema de Saúde, veiculada pelos meios de comunicação de massa, já deveria estar construindo esta perspectiva de atenção na saúde. A promoção da saúde, então, permeando o cotidiano dos serviços e o cotidiano da população.

Uma entrevistada considerou que a difusão da teoria e da prática da Promoção da Saúde ainda está predominantemente nos meios acadêmicos. Estes serão identificados no decorrer deste tópico.

S.F. "Não, fundamentalmente, eu acho que são pessoas que já tinham essa atitude, que vai pelas suas experiencias, pelos seus trabalhos e a facilidade de entrar em contato e essa nova consciência global que cria interesse dos meios 
acadêmicos, principalmente, mas acho que estamos ainda engatinhando nesta questão."

Outra expectativa de difusão diz respeito a uma das questões do roteiro temático das entrevistas: a entrada formal da promoção da saúde nos nossos órgãos oficiais. A difusão é reconhecida quando ela passa a existir integrando a estrutura do Ministério ou das Secretarias Setoriais.

A.V. "Não tem havido uma grande difusão. Eu acho que ainda falta muito. Estou aqui desde agosto de 1996, então, até o ano passado (1999) a Promoção da Saúde era um discurso. Desde o ano passado existe no Ministério uma estrutura de Promoção da Saúde, assim como uma coordenação ou divisão de Promoção da Saúde, que incorpora os elementos de Municipios Saudáveis, Escolas Saudáveis e tem estratégias muito bem definidas. Acho que é um grande avanço e, no ano passado, aconteceu uma grande conferência de Promoção da Saúde, foi o / Fórum Nacional de Promoção da Saúde, organizado pelo Ministério da Saúde. Então, acho que começa aí a se organizar um pouco mais, nos niveis políticos e acadêmicos e de serviços, nos aspectos de Promoção da Saúde. Mas, ainda acho que tem que se aprofundar um pouco mais."

Esta estrutura de Promoção, no Ministério, da qual o entrevistado se refere, diz respeito a um Projeto financiado pelo PNUD (Programa das Nações Unidas para o Desenvolvimento). Denominado como "Projeto de Promoção da Saúde", está ligado à Secretaria de Politicas de Saúde, mas não faz parte do organograma deste órgão federal. Tendo verba garantida até o ano de 2003, apresenta como objetivo: "ampliar a ótica da saúde dentro de uma nova concepção que tem como objetivo a qualidade de vida."

\footnotetext{
- Informações fornecidas através de comunicações pessoais com os técnicos que constituem a equipe do Projeto de Promoção da Saúde, do Ministério da Saúde.
} 
A seguir são identificadas as estratégias que mais foram utilizadas para a difusão da promoção da saúde, na década estudada. 


\section{1 - Municípios ou Cidades Saudáveis}

Os doze entrevistados citaram os Municipios ou Cidades Saudáveis como uma das estratégias que têm contribuido para a difusão da promoção da saúde no Brasil, iniciativa esta que, para alguns, facilita a operacionalização do conceito da promoção da saúde na prática.

J.Y. "Municípios saudáveis eu chamo de um movimento e não de um programa. Foi baseado na declaração de Ottawa em 86 sobre o que é promoção de saúde. Então, são estes principios gerais que eu te falei. 0 importante de municípios saudáveis é que ele é uma forma didática de entender melhor a concepção de promoção de saúde. Porque a proposta de municipio saudável é intersetorial. Deve envolver todos os setores possiveis e tem por objetivo principal melhorar a qualidade de vida e que um dos componentes da qualidade de vida é o setor saúde."

Grifou-se a frase no depoimento acima por esta visão ter sido manifestada por vários entrevistados ao falarem de município/cidade saudável. Segundo eles esta estratégia pode traduzir melhor o enfoque da promoção da saúde.

Segundo GENTILE (1999), primeira coordenadora do Projeto de Promoção da Saúde, na Secretaria de Politicas de Saúde do Ministério da Saúde, a OMS/OPAS define que:

"Cidade saudável é aquela em que as autoridades políticas e civis, as instituições e organizações públicas e privadas, os proprietários, os empresários, os trabalhadores e a sociedade dedicam esforços constantes 
para melhorar as condições de vida, trabalho e cultura da população, estabelecem uma relação harmoniosa como meio-ambiente físico e natural, alérn de expandirem os recursos comunitários para melhorar a convivência, desenvolver a solidariedade, a co-gestão e a democracia."

De acordo com essa autora:

"A concepção de municipios saudáveis não é um modelo que se entregue às autoridades municipais para que o apliquem diante dos cidadãos, mas uma estratégia da Promoção da saúde para o nivel local. É um processo que permite identificar os principais problemas de saúde e suas causas, procurando respostas de forma participativa com os principais protagonistas do municipio. Trata-se, pois, da adoção de mudanças nas dinâmicas que envolvem as relações entre pessoas e expandindo-se para as relações de cidadania, em busca de novos pactos entre governantes e a sociedade."

Nesse artigo, ora se refere a municipios, ora se refere a cidades saudáveis. No depoimento dos entrevistados, esta dupla referência também se manifesta. FERRAZ (1999), uma das entrevistadas deste estudo, foi a primeira autora a publicar um artigo e um livro sobre esse tema no Brasil. No livro "Cidades saudáveis: uma urbanidade para o Brasil" defende a adoção do termo "cidades saudáveis" por considerar: "(....)que o aspecto cidadania, assim como democracia, está mais implicitamente ligado, desde Platão, à concepção de cidade. Ademais, o termo cidade saudável é mais universal e está mais intrinsicamente identificado com a concepção e a filosofia do movimento internacional."

A experiência de FERRAZ em relação ao conceito de promoção da saúde deu-se através do movimento de cidades saudáveis, em Montreal, Canadá, mais precisamente, onde fez o curso de mestrado. Na entrevista, ela 
refere-se a esse processo, apresentando algumas razões que fundamentam a adequação dessa proposta no Brasil.

S.F. "(....)Achei este movimento cidades saudáveis. A participação dos municipios estava aí, dentro do setor saúde porque era o grupo da saúde que trabalhava com os municipios, mas de uma maneira ainda muito incipiente. Estava começando lá, naquela época as pessoas não sabiam muito bem o que era, o que ia dar. Era uma coisa muito nova ainda lá. Então, me embrenhei com este grupo. procurei o grupo em Montreal e pedi para acompanhar, inclusive estavam formando o comitê internacional. Participei das reuniões do Comitê. Com isso, participei da dinâmica da implantação de Cidades Saudáveis em Montreal e da Rede Quebequense de Cidades Saudáveis. Foi onde fiz o estudo pra ver como poderiamos implantar esta filosofia aqui no Brasil. Me encantei com a filosofia porque considero que é um salto qualitativo para o setor saúde, para poder agir no sentido da promoção de saúde. Então, a minha inserção na promoção da saúde é, exatamente, a partir daí, da década de 90 , chegando no Canadá, onde esta questão da promoção é muito desenvolvida, vamos dizer assim, porque os serviços já estão organizados.

D. Ela acontece no nível de formação do mestrado?

S.F. Foi exatamente onde encontrei, digamos assim, minhas dúvidas. Eu consegui primeiro constatar que era município mesmo. Nem era só municipio, era cidade. Então aquela inquietação que eu sentia, eu acho que eu encontrei respostas. Quer dizer, não respostas definitivas, muitas dúvidas, mas também algumas respostas relacionando o caminho. É realmente por aqui. E tanto que a questão dos sistemas locais de saúde depois perdeu completamente a legitimidade. E a questão do municipio se confirmou como uma instância realmente da política e, nesse sentido, eu me encontrei com um grupo, quer dizer o modo de pensar com o grupo do Canadá. Essa coisa de pensar: o poder 
local, o poder da comunidade, todas as diferenças, porque o choque cultural é imenso.

(....)Acho que no Brasil temos que pensar na Promoção da Saúde já de forma muito intersetorial e interdisciplinar. Não podemos cair nessa, digamos assim, não diria um erro, mas temos que aproveitar a experiência dos países hoje e o acúmulo do conhecimento para avançar. Não vamos achar que vamos promover saúde dentro do setor saúde. Acho que município saudável - cidade saudável traz esta possibilidade. Por isso que eu batalho muito por esta estratégia, que eu acredito que amplia na base, dá instrumentos para que o municipio faça esta abertura. É muito difícil você fazer a nivel estadual e federal, mas no municipio ela é possivel. Então, eu acho que promoção de saúde no Brasil, se eu tivesse encarregada de elaborar uma política de promoção de saúde, seria esta proposta que eu faria: trabalhar no nivel do municipio de forma intersetorial e fazendo gestão com os outros setores para que tenha esta visão e dar este foco também para a formação da promoção da saúde. Nós temos que construir um outro saber que é multidisciplinar e transdisciplinar."

Segundo VIANA (1998): "Já é extensa a lista de autores que advogam um novo papel para o local e vêem as cidades como força de contraposição ao processo de anomia social que a globalização produz."

A cidade emerge como ator político, reforçada pelo processo de descentralização, que apesar de caótico, vem acontecendo em alguns setores. A saúde, a educação e a assistência social, na década de 90 , exercitam o desafio de conformar novas formas de gestão, de relacionamento e de implementação de suas ações. (VIANA 1998)

As novas formas de relacionamento entre estes setores visam promover politicas integradas, que favoreçam a otimização dos recursos, a cooperação 
entre os diversos órgãos governamentais e não governamentais, a mudança nas formas de prestação de serviços e de relacionamento com a população.

A intersetorialidade da qual se refere a entrevistada S.F., segundo JUNQEIRA (1998), seria "uma articulação de saberes e experiências dos diversos setores, como saúde, educação, assisténcia social, esportes, cultura, meio ambiente para alcançar melhores resultados para a população."

Essa articulação de saberes e práticas, no "planejamento, realização e avaliação das ações para alcançar efeito sinérgico em situações complexas", através da interpenetração de diferentes disciplinas ou áreas de conhecimento, originaria um outro saber. (JUNQUEIRA 1997) Espera-se que ao se superar a prática vigente de atuação isolada dos técnicos dos diferentes setores, se descubram as conexões presentes ou a teia de relações existentes entre os problemas diagnosticados e sejam propostas melhores formas de enfrentá-los em seu conjunto.

Interdisciplinaridade é aqui, também, entendida da forma como JAPIASSU citado por PEREIRA et al (1991) a refere:

"Uma relação de reciprocidade, de mutualidade, que pressupõe uma atitude diferente a ser assumida frente ao problema do conhecimento, ou seja, é a substituição de uma concepção fragmentária para unitária do ser humano. É uma atitude de abertura, não preconceituosa onde todo conhecimento é igualmente importante. Pressupõe um atitude engajada, um comprometimento pessoal."

Portanto, mais do que uma interpenetração de diferentes áreas ou setores, requer uma determina postura do profissional para esse fazer interdisciplinar. Essa postura deve favorecer o intercâmbio, a comunicação, a 
cooperação, o questionamento de saberes e práticas visando um objetivo comum. As resistências ou obstáculos para o surgimento e consolidação deste tipo de prática nas nossas instituiçōes, são lembrados pelos entrevistados, como pode se observar no depoimento abaixo.

P.C. “(...)Uma outra estratégia, ou um aspecto destas estratégias que eu volto a dizer, é o movimento de cidades saudáveis, que começou com uma discussão localizada, entre alguns técnicos e, ouvi dizer, entre grupos de assessores da OMS, mas que acabou crescendo num nivel fundamental. No momento, nós temos um número imenso de redes de cidades que se propõem a se desenvolver como um espaço saudável, espaço humano saudável, sobretudo na Europa e no Canadá. Temos mais de 1000 cidades no mundo envolvidas nisto, e, em 10 anos, foi um crescimento muito grande. Tem muito estudo académico nesta área. Tem algum incentivo para fazer isto. Mas, é ainda uma área do campo académico que não produz o impacto que poderia, dada às resisténcias que encontra dentro da própria instituiçáo(...)

A experiência brasileira com municipios/cidades saudáveis foi analisada por FERRAZ (1999) e MENDES (2000). Essa experiência brasileira é refletida por alguns entrevistados, que oferecem dados do contexto e situam os bastidores da entrada desta proposta no Brasil.

Segundo FERRAZ (1999), a primeira cidade brasileira a implantar "formalmente um projeto de cidades saudáveis" foi São Paulo, em 1991. Um dos participantes deste estudo trabalhou neste projeto e fala como sua participação neste o influenciou:

P.C. "(...)Eu diria que uma coisa fundamental, foi uma tarefa que eu assumi na Prefeitura de São Paulo, em 1990, de apoio à agenda do intercâmbio BrasilCanadá ou São Paulo-Toronto, entre as duas cidades, para o desenvolvimento 
de cidade saudável no Brasil. Então, como tarefa de organizar esta agenda, eu passei a ter um contato muito intenso com esta discussão. $E$ diria que o conhecimento da carta de Ottawa, enfim trouxe, no papel, uma série de coisas que eu já começava a observar. O meu primeiro contato formal foi aí.(....)"

Na avaliação de FERRAZ (1999), "com importante apoio da OPS, Campinas elaborou, em 1994, uma proposta consistente de cidade saudável." A participação da OPAS neste projeto é relatada por um dos entrevistados, que acompanhou esta iniciativa.

E.M. "Vem, então, já na década de 90, a proposta de município saudável. A OPAS entrou nela muito tarde. Entrou, veio para o Brasil por um acidente.

D. Como assim?

E.M. E, o prefeito de Campinas, Magalhães Teixeira, foi fazer uma visita a Washington, pedir um empréstimo no BID. Foram lá visitar o Carlyle;, que era um brasileiro, diretor da OPAS. Yunes era muito amigo do Magalhães e trabalhava em Washington. Então marcou uma conversa, uma visita protocolar do Carlyle com Magalhães Teixeira. E, o Carlyle, naquele momento, tinha lá uma oferta de um dinheiro internacional para fazer municípios saudáveis na América Latina. Perguntou ao Magalhães se ele não queria U\$90.000,00 (dólares) para fazer na cidade dele. Teixeira topou, prefeito brasileiro nunca fala não para dinheiro. Ainda que não soubesse muito bem o que era. Então, 0 Teixeira veio e a seguir veio uma missão da OPAS depois explicar o que era município saudável. Foi um desastre completo porque ninguém se entendia, não sabiam e...

\footnotetext{
"Dr Carlyle Guerra de Macedo foi Diretor da OPAS por vánios anos (localizados registros do periodo de 1983-1993).
} 
D. A comissão, com os técnicos da secretaria?

E.M. A comissão com todos os secretários do governo. Todos os secretários do governo, por 1 1/2 dia reunidos, deixaram tudo que tinham para fazer para ouvirem a proposta da OPAS. Foi um desastre. Os secretários, acho, nunca mais quiseram saber desta proposta. Foi tal a forma...E depois, esta missão fez o desastre e foi embora. Tocou a mim acompanhar este projeto em Campinas, pela OPAS. Depois fui chamado por Magalhães Teixeira, ele me falou: 'Eugênio não entendi muito bem o que é municipio saudável, mas nós vamos fazer, quero fazer.' Ai eu falei pra ele: 'Não se incomode muito com isto não. Qual o problema que o Sr. tem aqui, que não resolve?' Eu nem falava Sr. porque... ele era mineiro também, a gente ficou logo amigo. Eu vinha trabalhando como consultor da Secretaria Municipal de Saúde de Campinas, onde Carmem Lavras era a Secretária e trabalhando na distritalização em Campinas, todo este movimento da territorialização, tava uma efervecência na Secretaria. Então eu falei com ele: 'Qual o problema que o Sr. não resolve?' 'O problema que eu não resolvo é menino de rua, eu quero resolver este problema.' 'Então o senhor faz um levantamento ai e vê de onde esses meninos vêm e eu volto dentro de 15 dias.' Voltei lá 15 dias depois, ai ele disse: 'Já entendi o que é que você queria com municipio saudável.' A maior proporção dos meninos vinha de uma área só de Campinas, que era o complexo São Marcos. Então captou.

E ai eu já estava trabalhando teoricamente com a teoria da produção social da saúde. Ou seja, saúde é algo que é socialmente produzido, que vocé acumula e desacumula, então aquela doença, que era o menino de rua, era socialmente produzida pelas condições de vida no complexo São Marcos. Ai ele falou assim: 'Entendi, nós vamos trabalhar no São Marcos e vamos mudar aquilo lá'. E, neste meio tempo havia duas pessoas de Minas Gerais trabalhando comigo, o Marco e a Cibele. Então nós começamos um trabalho muito legal em Campinas, na SARNORTE (Secretaria de Administração Regional Norte) no sentido de melhorar o trabalho intersetorial, no sentido de 
melhorar as condições de vida daquelas pessoas e daquele bairro. E se não fosse o prefeito ter morrido, infelizmente, teria sido feito um a trabalho fantástico porque o vice-prefeito não entendeu nada disso e não sei a quantas anda este projeto hoje. Mas, foi um belíssimo projeto. Foi aí que eu sai da Distritalização e falei com Carmem: 'Vamos sair da Secretaria de Saúde, vamos aproveitar esta chance.' E fomos trabalhar com uma administração regional. Dai surgiram uns 10-12 projetos; surgiu a renda minima articulada com a educação, com o projeto de melhoria das professoras, com o projeto de manejo de habitações em condições muito precárias de uma outra área, com estradas.

D. Aí vocês conseguiram os secretários novamente?

E.M. Não, ai não precisava dos secretários porque o Magalhães descentralizou para as secretarias regionais. Foi muito dificil convencer o secretário regional, mas no fim ele se convenceu e foi um trabalho fantástico. Então, nós criamos, também, o "approach" brasileiro na questão municipio saudável, entendeu? A partir da experiência de Campinas."

O apoio da OPAS nesta iniciativa de Municipio / Cidade Saudável, como pôde se evidenciar no depoimento acima, não se restringiu ao financeiro. Uma assessoria técnica foi feita, visando a operacionalização dessa proposta. A realização deste tipo de seminário ou workshop com o Secretariado Municipal continua sendo, até a atualidade, uma estratégia adotada para a sensibilização de gestores municipais visando despertar para a necessidade de novas tecnologias ou formas de gestão.

O approach brasileiro pode ser entendido como identificação de um problema-chave para a autoridade local (o Prefeito) e o enfrentamento intersetorial deste. Foi definida uma base geográfica de atuação que, no caso em questão, foi a Região Norte da cidade ou municipio de Campinas. 
Outro aspecto a ser ressaltado no depoimento acima diz respeito à sustentabilidade das experiências de Municipios / Cidades Saudáveis no Brasil. Estas têm baixa resistência a troca de governo ou a mudanças administrativas. (MENDES 2000)

Outro participante desta pesquisa cita a experiència de Campinas $e$, também, tece considerações sobre a descontinuidade desta proposta devido à vulnerabilidade política:

J.Y. "O municipio de Campinas, por exemplo, até ganhou um prémio internacional da OPAS como Municipio Saudável, mas foi um compromisso politico do prefeito. Quando iniciou-se a experiéncia em Campinas o prefeito reestruturou até a secretaria da saúde em função da concepção de municipio saudável. Quer dizer, a nivel central, a secretaria de educação, transporte e saúde, mas, a nivel regional, eram Sub-Secretanias intersetoriais. Foi uma experiência muito rica. O aprendizado de municipios saudáveis é, também, a vulnerabilidade política, porque quando o prefeito termina a gestão dele ou quando ele morre, entra um substituto, ou quando entra um outro partido, ou mesmo do próprio partido, na nossa cultura não existe a cultura de dar continuidade ao que é bom. Sempre quer.....

D. Deixar a sua marca, o seu carimbo...

J.Y. "Exatamente. Então, por exemplo, Campinas infelizmente não continuou na proposta. Alguma coisa deve ter ficado. A experiência de Campinas é um aprendizado importante em termos de nos preocuparmos com a sustentabilidade do processo de Municipio Saudáveis, e a estratégia é através dos Conselhos de Saúde da população. É o que teria mais chance de continuar o processo." 
O dia 07 de abril de 1996, Dia Mundial da Saúde, foi comemorado com o tema: "Municípios e comunidades saudáveis - para uma vida melhor."

Em 1998 foi realizado em Sobral o I Encontro ou Fórum Brasileiro de Municipios Saudáveis. Um dos organizadores deste evento participou desta pesquisa e informou as experiências internacionais que foram lá apresentadas.

L.A. "(.....)Em 98, nós realizamos em Sobral o I Encontro, o I Fórum Brasileiro de Municípios Saudáveis. Foi um momento importante, os quebequences vieram, os mexicanos vieram, veio o pessoal da Venezuela. Então nós conseguimos aqueles interlocutores nossos. Continuou junto esse processo.(...)

A Declaração de Sobral preconiza que "os municipios brasileiros precisam assumir a tarefa de formulação e execução das politicas públicas intersetoriais que respondam às demandas sociais" e recomenda "a iniciativa de articulação de uma rede brasileira de cidades e municípios saudáveis através do CONASEMS. "(FIOCRUZ 2000)

No XV Congresso Nacional de Secretários Municipais de Saúde, realizado na cidade do Rio de Janeiro, organizou-se uma oficina de trabalho preparatória ao lançamento da Rede Brasileira de Municipios Saudáveis. Nesta ocasião, foi apresentada uma Declaração de Fundação da Rede, que teve seus princípios discutidos anteriormente, neste estudo. A Rede, até o momento, ainda está sem sede própria.

Segundo a equipe do Projeto de Promoção da Saúde do Ministério da Saúde, em relato na Revista de Promoção da Saúde n², esta Oficina contou: 
"Com a presença de cerca de 80 participantes, representando 36 municipios de todas as quatro regiões brasileiras, entre prefeitos, viceprefeitos, secretários municipais de saúde, técnicos da área, professores universitários e contando ainda com representantes e consultores de organismos internacionais.

Foram discutidas a revisão dos conceitos e do histórico do movimento internacional de cidades saudáveis e a instabilidade politica face às mudanças da administração municipal. O Prefeito de Crateús, Paulo Nazareno, foi designado coordenador da Comissão Provisória, que deverá providenciar uma reunião para estabelecer uma estratégia de trabalho, convocando amplamente os prefeitos interessados."

A.V. "(...)Até o ano passado (1999), se falava em Municipios Saudáveis assim dispersos neste imenso Brasil. Então, eram aqueles pontos, eram dezenove pontos. Com a participação do Ministério da Saúde póde se conformar a Rede Brasileira de Municípios Saudáveis. Então, é uma forma de ir, digamos, organizando as iniciativas que vão se desenvolvendo com a questão de Municípios Saudáveis. Foi uma questão, uma iniciativa... Bom, se iniciou por fora do Ministério da Saúde e agora ele está retomando o seu papel.(...)

Segundo um dos pesquisados não se deve associar a estratégia de município saudável, exclusivamente, à idéia de promoção da saúde ou à construção de ambientes favoráveis à saúde. Um município saudável é o produto ou o resultado das ações de promoção. Ainda, pode ser visto como uma tecnologia ou ferramenta de gestão do viver urbano.

M.A. "(...) Precisamos de transformar a cidade, temos que transformar a forma de olhar a cidade, de gerir a cidade, de se relacionar na cidade. O discurso é mais urbano, não é um discurso da promoção, tipicamente. Então, por exemplo, me estranha quando eu vejo uma relevância da OPAS... Outro dia, em uma 
reunião da OPAS, lá na Faculdade, falando que o eixo é a promoção, que o municipio saudável é uma das expressões da promoção, entendeu? Eu tenho dificuldade pra entender isso, eu acho assim que o municipio saudável é a mudança da gestão urbana para melhoria da saúde, acho que está no campo da promoção, mas eu não consigo ver a promoção e as outras coisas como parte. Eu acho que o municipio saudável é a própria mudança que isso pode até gerar, isso é uma estratégia de promoção, até pra mim a mais importante dn ponto de vista geral." 


\section{2 - Ambientes Saudáveis}

Foram aqui agrupadas algumas estratégias de difusão relatadas que visam gerar ambientes saudáveis ou produzir saúde e bem-estar em determinados espaços.

Sob este prisma, foi realizada a III Conferência Mundial de Promoção da Saúde: Ambientes Favoráveis à Saúde, em Sundsvall, no ano de 1991 , conforme discutido anteriormente neste estudo.

Um participante desta pesquisa esteve em Sundsvall e relatou que sua entrada no movimento da promoção se deu a partir da ida a este evento. $E$ ao comentar o significado desta participação ao longo da entrevista, considera que, só neste momento, compreendeu porque ele foi convidado pelos suecos para ir a este encontro.

P.B. “(...) Na reunião de Sundsvall eu não a compreendi assim. Quer dizer, eu não compreendi a reunião de Sundsvall como parte de um processo. Então, pra você ver que eu estava ingenuamente, entrando já na terceira conferência sem reconhecer o movimento internacional de promoção da saúde. Eu fui lá, não entendi porque fui convidado.

D. Por quem o Sr. foi convidado?

P.B. Por eles, pelos suecos, recebi uma carta. Bom, ir à Suécia, ótimo! Preparei minhas férias para continuar desfrutando da Europa depois e ful. Não sei, por quem fui indicado. Lá encontrei várias pessoas. Ouvi a palavra "empowerment" várias vezes. Encontrei a Nelly Candeias, nos encontramos no Aeroporto.... 
que eu não sei mais o nome do aeroporto de lá. Pegamos um avião pequeno para Sundsvall. Ela ia depois para Copenhague, ou sei lá pra onde, para uma reunião da UIPES. Então, aí, eu, sabe? Pá! Comecei a me localizar no negócio, mas sem entender muito aquela história toda... Estava lá a Noêmia [Cligman] que é muito exigente, que é do 'metié'. Eu nunca tinha trabalhado com educação de saúde, a não ser como pediatra e era um sanitarista. Trabalhava com saúde publica, já, nessa altura, eu ainda era diretor da ENSP.

D. Então, no contexto da sua vida profissional o Sr. era diretor da ENSP?

P.B. Nesse momento, quando eu fui a Sundsvall... Quer dizer, o convite deve ter sido por isso (....)"

Então, até 1991, este pesquisado não havia tido contato com esta visão de promoção, nem havia se aproximado dos que a intitulavam como a "nova saúde pública". A conferência de Sundsvall contou com dois representantes brasileiros. É importante ressaltar que ele, ao presenciar o debate dos "paises desenvolvidos" sobre ambientes saudáveis, também, como tantos outros, se perguntou: isto se aplicaria à realidade brasileira?

P.B. “(....)Não, mas a idéia de ambientes saudáveis era aquela história, que hoje eu acho extraordinariamente inteligente, que é uma das frases, pra mim, chaves, da promoção de saúde que é: 'fazer das escolhas saudáveis as mais fáceis'. Quer dizer, isso, o entorno, a lei, a política é que favorecem. Eu li assim. Apesar que eles traduzem isso assim: 'banheiros que tenham lugar para que velhos se agarrem para tomar banho e não cair; móveis que não tenham cantos...' Eu achava tudo aquilo alucinante, quer dizer, mas eu trabalho num lugar, no Brasil, que é cercado de favelas, que não tem um móvel dentro de casa. O negócio é não deixar as crianças caírem no mangue para não voltarem com febre. (...)Meu problema com a questão ambiental era tirar as fezes da 
comida e despoluir a água que as pessoas recebiam, dar mais água. E as pessoas lá discutindo ambientes favoráveis; se os móveis tinham ponta, se colocava piso anti-derrapante ou não. Nós fizemos esse trabalho enfim, de conversas e encontro lá... E a Margareth [Kilson ou Hilson], que encontrei em Sundsval, me colocou: 'Puxa, vamos tentar trabalhar juntos e tal.' A gente se gostou muito assim de cara e eles trabalhavam com o Chile. E o trabalho era apoiar associações internacionais. Mas, isso morreu, eu cheguei no Brasil e comecei a trabalhar fortemente no tema da promoção, ler bastante, comecei estudar, criamos um pequeno grupo de trabalho aqui, mas tudo ainda em compasso de espera. Eu estava na presidência da FIOCRUZ trabalhando muito na promoção sem denominá-la como tal."

Segundo alguns dos entrevistados, os locais onde as pessoas vivem, os espaços ou ambientes que têm sido privilegiados para intervir são: as escolas, as indústrias e os hospitais.

D. Então as estratégias de difusão aqui no Brasil o Sr. considera.

J.Y. "Escola promotora de saúde, ambientes saudáveis, que incluem concretamente, a indústria, o hospital e...

(....)Essa idéia de ambientes saudáveis está tendo uma experiência interessante... Foi feito um convênio entre a OPAS e o SESI de industrias saudáveis e o Ministério está acompanhando. (...)Estamos trabalhando com a idéia de Hospital Saudável, também. Entra a humanização do atendimento, do ambiente saudável. A idéia também, ainda não chegamos lá, mas é até Cadeia Saudável. Enfim, um ambiente de vida saudável. É essa a concepção que a gente tem trabalhado. O exemplo, em ambiente saudável, é que entre os vánios benefícios, não só para a qualidade de vida; mas até em termos de redução da violência. Como é que se relaciona ambiente saudável com redução da violência? Por exemplo, você observa que nos bairros mais violentos, nas áreas 
mais violentas não existe nada saudável. Não existe uma praça, um jardim, um banco, um centro de esporte, espaço de lazer, uma igreja, uma associação comunitária, ou seja, a qualidade de vida é muito ruim. A criança e o adolescente, principalmente, não está na escola, não tem ocupação, quer dizer, esta falta de alternativa, de qualidade de vida, é um fator que predispõe à violéncia. Faltaram os equipamentos sociais. O que sobra é o jogo, a bebida no bar, o alcoolismo, as drogas, o roubo."

\subsection{1 - Escolas Promotoras de Saúde}

A estratégia de Escolas Promotoras de Saúde foi citada, mas não assumiu grandes dimensões na fala dos entrevistados e, como será discutido a seguir, foi até questionada. A proposta de atuação dentro da escola orientada pelos conceitos de promoção da saúde visa superar a prática vigente da maioria dos programas de educação em saúde no ambiente escolar, que são desenvolvidos de forma verticalizada e desvinculados dos conteúdos programáticos do currículo escolar.

SILVEIRA (2000) ao analisar a Declaração de Sundsvall, considera que:

'Ainda que a 'escola' não tenha sido incluida como um 'espaço onde as pessoas vivem', já há uma referência mais direta ao papel desta instituição, caso se considere que ela também é determinante do 'acesso aos recursos para viver e as oportunidades para ter maior poder de decisão.' Entre as estratégias para assegurar a promoção de saúde, a Conferência de Sundsvall incluiu a de capacitar comunidades e individuos a ganharem 
maior controle sobre sua saúde e ambiente, através da educação e maior participação nos processos de tomada de decisão."

Fundamentados nos documentos internacionais sobre Escola Promotora de Saúde (OMS 1997; OPAS 1998; OPAS "sd"), questiona-se a avalanche de projetos que é proposta à escola de forma desarticulada, muitas vezes com superposição de ações e com diretrizes e intencionalidades dispares. O próprio setor saúde enfrenta os problemas com equipes de diversas áreas: saúde ocular, saúde bucal, prevenção das doenças sexualmente transmissíveis, saúde mental etc.

Segundo o referencial teórico disponivel sobre escolas promotoras de saúde os programas setoriais passariam a ser programas intersetoriais e interinstitucionais, pois a partir da comunidade escolar se pensaria os entornos e os demais ambientes onde vive a comunidade escolar.

A proposição da terminologia da estratégia Escola Promotora de Saúde foi questionada por uma das entrevistadas:

V.L. "Eu lembro de uma questão, que, na ocasião, me incomodava muito, que era... Até, pode parecer, agora, uma espécie de heresia, nesta altura da vida Até eu revejo, a minha posição porque ... Mas é uma questão de nomenclatura também ... A questão dos "Settings" de promoção e, sobretudo, a questão do nome dado à Escola Promotora de Saúde. Foi uma questão que eu levantei porque a Escola Promotora de Saúde a mim, como educadora, dava a idéia de que você pressupõe a existência de escola não promotora de saúde. Entende? Eu acho que Escola Promotora de Saúde, para mim, pareceu uma aberração. Acho que todas as escolas, obrigatoriamente, deveriam ser promotoras de saúde. Então, eu não consegui aceitar esta nomenclatura. Mas, eu entendo,

\footnotetext{
Grifo no original.
} 
perfeitamente, que se passa, realmente, na promoção, este esforço de em determinados ambientes. (...) Foi uma visão muito critica mesmo, propositadamente crítica."

A entrevistada apresentou estes questionamentos ao participar de um debate sobre Promoção da Saúde, em 1996, no Chile, em um Congresso da UIPES/ORLA. Ela considerou que "(...) realmente, nesta altura, então, eu estava assim, numa postura muito crítica com relação ao movimento de promoção."

Esta proposta tem um discurso homogeneizador, pois não problematiza as dificuldades já encontradas pela área de saúde escolar. SOSSAI (1992) ao pesquisar sobre as características dos órgãos responsáveis pela área de saúde escolar, no Brasil, levantou as principais dificuldades, que os coordenadores desta área identificavam para o desenvolvimento dos Programas. Em ordem decrescente foram: insuficiencia de recursos humanos qualificados, insuficiência de recursos materiais e financeiros, falta de integração entre os órgãos envolvidos

Segundo a OPAS (2001) para se implementar a promoção da saúde no âmbito escolar faz-se através dos seguintes componentes: "educação para a saúde com um enfoque integral, criação de ambientes e entornos saudáveis e planejamento e oferta de serviços de saúde e alimentação".

Percebe-se, com a leitura dos documentos, que há uma opacificação dos conflitos presentes para a construção desta prática. Ainda que critiquem os programas setoriais, de caráter meramente informativo, que têm como objetivo principal a mudança de comportamentos individuais no enfrentamento de determinados problemas de saúde, no ambiente escolar, os documentos da estratégia escolas promotoras de saúde, da mesma maneira que as 
Declarações e Cartas das Conferências Mundiais de Promoção da Saúde, desconsideram os obstáculos até o momento enfrentados por aqueles que tentam ações intersetoriais.

Descobrir as conexões presentes ou a teia de relações existentes nos problemas enfrentados no ambiente e entorno escolar requer compartilhar de saberes e práticas, requer capacitação, ruptura, esforço e persistência. Requer a superação de uma prática que tem insistido em prescrever a priori receitas para a população brasileira, onde os profissionais da saúde, de forma verticalizada e com programas, na sua maioria, desvinculados dos conteúdos programáticos do currículo escolar. Por outro lado, requer a identificação dos principais obstáculos para a priorização da educação nas políticas públicas.

I.C. "(...) Por que pensar que a gente vai ter uma coisa que chama promoção da saúde e que isso vai trabalhar o conjunto das coisas ou querer que o pessoal da escola ou o que eles fazem ou o que vierem a fazer como conceito mais adequado com relação à saúde? Nós podemos chamar isso de promoção de saúde, mas eu não gostaria que eles chamassem de outra coisa que não fosse trabalhar a educação de uma forma integral e preparação para a cidadania e pra vida de uma forma melhor. Então é....não sei se é com essa idéia de difusão ou de querer dizer que todo mundo está fazendo promoção, não sei se isto é uma questão central, uma questão chave."

\subsection{2 - Indústria Saudável}

Uma outra estratégia de difusão que foi identificada pelos entrevistados foi a de Indústria Saudável. Esta se fundamenta na importância do trabalho na vida das pessoas e se ocupa em pensar possibilidades para que este ambiente 
de trabalho favoreça a saúde. Portanto, ora identifica danos que este trabalho pode ocasionar e trabalha na determinação destes; ora estimula que este trabalhador desenvolva hábitos mais saudáveis no seu dia a dia

Na I Oficina de Promoção da Saúde no SUS, realizada pelo CONASEMS em parceria com o Ministério da Saúde, no dia 17 de maio de 2000, em Brasilia, foi apresentada oficialmente a proposta de Indústria Saudável no Brasil, pelo coordenador deste projeto no SESI. Este, ao ser entrevistado para este estudo, apresentou alguns elementos para a caracterização desta iniciativa.

V.P."(....)São serviços dentro das empresas e dentro das escolas, são dentro dos ambientes de trabalho. Não é mais a população que vai ao serviço. $O$ conceito clássico de que o serviço deve ficar perto da população continua, se vocé exigir que um indivíduo vai consultar no posto de saúde, que hora que ele vai? Ele trabalha o dia inteiro, o patrão fica zangado. Também, neste trabalho aqui, onde a clientela fundamental é o trabalhador por causa da indústria, o esforço principal está voltado para a oferta de serviços, e, portanto a construção de toda uma estrutura, uma lógica nova de trabalho, a oferta de serviços nas empresas. Você move, tira os serviços de dentro, do que nós chamamos aqui de Centros de Atividades, dos Centros de saúde e joga estes serviços para dentro das empresas, começa a trabalhar com unidade móveis, com equipamentos desmontáveis, nas várias áreas: no atendimento da mulher, na realização de exames complementares de saúde, atendimento de odontologia, tudo isso começa a mover para dentro das empresas, uma coisa muito forte. Desenvolvimento de tecnologias, de vários trabalhos neste sentido. Além disso, há programas, a grande ênfase começa a ser, efetivamente, a questão da promoção de saúde, no sentido de procurar evitar a doença. Isso, de certa forma, cria um problema porque a saúde tem que ser integral, vocé tem que atender os indivíduos. Muitas vezes, surge o problema de para quem encaminhar? Muitas empresas têm seus próprios serviços de saúde, 
encaminhar para os serviços públicos nem sempre é a solução, porque os serviços públicos têm tantos problemas, a oferta é tão precária. Então, você não consegue atender. Procura-se muito trabalhar esta questão de como resolver o problema do atendimento dando ênfase para a promoção da saúde, que é o centro da atividade. Concretamente, procurando desenvolver essa iniciativa da Indústria Saudável, que é uma iniciativa a partir da idéia de Municipio Saudável, por isso, que ela foi construida junto com a Organização Pan-Americana de Saúde e que ela começa a trabalhar em um conceito muito importante, que é o conceito das parcerias.(..) Acho que isto está nos ajudando a sair dos problemas institucionais sob o nome de parceiras. (....)"

Reconhecendo que a idéia ou concepção de Indústria Saudável advém de um desdobramento dos movimentos de cidades/municipios saudáveis ou de ambientes saudáveis, no capítulo de fundamentação do projeto SESI: indústria saudável se evidencia a pertinência de adotá-lo devido à visão aglutinadora do conceito, ou melhor, sua visão mais integrante ou lógica da intersetorialidade. "Este é um conceito claramente integrador, uma idéia matriz que permite, ao mesmo tempo, agregar sob um único guarda-chuva os múltiplos serviços que o SESI proporciona e oferecer soluções às demandas mais concretas das empresas do setor indústria" (SESI 2000)

Mais uma iniciativa fomentada pela OPAS, que tem oferecido apoio técnico ao projeto. O conceito de parcerias é citado, como uma altemativa que pode significar a superação de deficiências institucionais. Espera-se, através desta, compartilhar recursos - conhecimento, tecnologia, serviços, recursos humanos, populações etc - e, assim, potencializar a capacidade de resposta institucional.

Nos dias 06 e 07 de abril de 2000 foi realizado em Brasilia o workshop Promoção da saúde e ambientes de trabalho saudáveis: custos e benefícios. 
Uma matéria, no Jornal do SESI Nacional (2000) relata o que aconteceu neste evento e as organizaçōes envolvidas: "Durante o encontro, foram definidos os conceitos para a criação do Programa SESI Indústria Saudável, que deverá conferir um Selo de Qualidade às empresas que a ele aderirem.(...) Presentes ao evento, parceiros do SESI no programa, como o Governo Federal, por intermédio dos Ministérios da Saúde e da Previdéncia Social, Organização Internacional do Trabalho - OIT, Organização Mundial da Saúde - OMS, Organização Pan-Americana de Saúde - OPAS e a Agência de Promoção de Exportações - APEX"

O representante da OPAS entrevistado falou um pouco da natureza desta parceria da OPAS com o SESI:

A.V. “(....)Por exemplo: nós, no ano passando, estávamos discutindo Municipios Saudáveis; estávamos discutindo Escola Saudável e Indústria Saudável. Dos três, a questão dos Municipios estava mais avançada e de Industria Saudável, estava iniciando. Nós sabiamos que seria ... que estávamos lançando mais uma... Como diria... uma semente? Pensávamos... que não tínhamos, no discurso, atrativos para este grupo... No entanto, estamos agora trabalhando em aspectos teóricos, metodológicos e operativos das Industrias Saudáveis.

\section{Em parceria com o SESI ?}

A.V. Com parceria com o SESI, com a Universidade e, particularmente, com a equipe do Ministro. Já que, quando existe uma decisão política, se faz com que as coisas se facilitem mais. Os grupos técnicos se dispõem a reunir, designam tempo para isto.(....)"

A.V. “(...)Acho que, daqui a 4 semanas, vai se iniciar a $1^{a}$ industria saudável que está dentro deste processo Então, estas são as principais estratégias: 
primeiro, a decisão politica de estabelecer um programa; a identificação dos principais componentes; a aglutinação das forças; a participação, não pelo controle social, mas a participação do mundo acadêmico, das instituições, digamos, dos atores sociais, referentes à saúde ... Acho que são as principais, que posso dizer. "

J.Y."(...) Isto é, de como garantir nas indústrias e ambientes de trabalho um meio saudável. Isso, com o Dr. Pinto, agora, o convénio foi feito com o Presidente da Confederação Nacional das Indústrias, que é uma coisa mais alta. Agora, é o Dr. Vítor Pinto que está coordenando a execução do projeto.(....)

O projeto SESI: indústria saudável além de definir o que entende pelo conceito, apresenta os pilares básicos que caracterizam esta proposta, expõe as condições minimas para a adesão da empresa, identifica os compromissos formais que esta deverá assumir, estabelece os incentivos e vantagens e os caminhos que deverão ser percorridos para que a empresa possa receber e permanecer com Selo SESI - Indústria Saudável. (SESI 2000)

Pode-se questionar se esta proposta não corre o risco de se transformar em mais um certificado de "qualidade" para mediar as diversas normas da saúde do trabalhador, 0 conflito de interesses entre trabalhadores e empregadores, entre produção e meio ambiente, entre as novas tecnologias e o mercado de trabalho etc. As expectativas com a difusão desta estratégia são expressas sem considerar o terreno dos conflitos de interesses que estão em jogo.

I.C. “(...)Então a gente está vendo que até alguns campos tradicionais, vêm incorporando algumas metodologias da promoção de saúde para trabalhar e vêm tendo mais sucesso com isso. A gente já notou isso em relação à atividade física em especial, em relação à nutrição e, certamente, os outros campos vão 
se aproximando também. E mesmo em campos muito comuns, por exemplo, vamos pegar o campo lá da saúde do trabalhador de um lado e a idéia da empresa saudável do outro: olha a quanto tempo nós temos estas normas todas, as $M R$. MR não sei quanto, a $M R$ não sei quanto, a JB não sei o que. Quantas normas e as empresas continuam lá, estão lá e a gente não consegue fazer. Não que a gente seja contra ou queira abolir as normas, mas se elas já existem há tanto tempo e ainda não conseguiram, portanto, está faltando alguma coisa. O conceito da empresa saudável não abole tudo isso, mas trabalha numa outra lógica, de como construir um ambiente de trabalho mais saudável. Aí vocé põe todos os atores em interação - os patrões, os empregados e o entorno da empresa para trabalhar com uma determinada metodologia, que não negligencia tudo isso, mas que não é aquilo, que eles possam ter como resultado mais saúde."

Um dos entrevistados, ao falar sobre o investimento financeiro que tem sido feito na área, distinguiu a promoção da saúde proposta por estas empresas da promoção da saúde idealizada pelos sanitaristas.

M.A. "(....)Eu acho que tem tido investimento na área de saúde do trabalhador, que as empresas estão investindo na promoção da saúde, mas acho que tem uma lógica de uma promoção da saúde utilitarista, quer dizer, eu acho que nós discutimos mais a promoção da saúde no ponto de vista humano, ponto de vista da cidadania, ponto de vista da autonomia, ponto de vista da liberdade. $E$, as empresas discutem promoção num ponto de vista utilitarista, principalmente, depois que elas fizeram ajuste de mão de obra, chegaram ao número, exemplo do PONQ, eles tinham 400 mil funcionánios, hoje eles tem 80 ou 40 mil, mas eles chegaram a um número que eles disseram assim: 'Esta é a nossa força de trabalho!' Eles chegaram a um número dez vezes menor que eles tinham com a produtividade vinte vezes maior. a questão da saúde ganhou uma dimensão económica. Então, a pessoa adoecer, morrer ou faltar, tem implicações com a 
questão da produção. Então está tendo investimento nisso, essa coisa de promoção de uma forma utilitarista, vamos promover saúde...

D.Dai enfoca estilo de vida, que eles têm trabalhado muito...

M.A. Até que não, porque eles também trabalham com coisas como direção defensiva, que tem a ver com coletivo, quando vocé fala diversão também não quer atropelar o outro, mas não entra um pouco no papel social da empresa, fica nesse limite."

\subsection{Incentivo para Publicações}

Entre as estratégias de difusão citadas, ainda, foi identificado o lançamento, no Brasil, de publicações referentes ao tema de promoção da saúde.

J.Y. "(....)Uma outra estratégia, nós criamos uma revista de promoção de saúde, no sentido de registrarmos experiências concretas nessas áreas. Vamos fazer uma publicação sobre estudos de caso, que vão em direção à promoção de saúde.(....)"

O Projeto de Promoção da Saúde, do Ministério da Saúde, financiado pelo PNUD, lançou em agosto de 1999 o primeiro número da Revista de Promoção da Saúde, veículo específico previsto na formulação inicial do Projeto. Com o tema "Instrumento de luta", no seu primeiro editorial, informa os objetivos desta publicação: “(...) Ao divulgar experiências e abrir espaço para opiniões e debates, ela estará incentivando o surgimento de novas experiências 
e contribuindo para que todas elas se consolidem em projetos viáveis e necessários à saúde e cidadania de milhões de brasileiros."

P.B. "(...)Eu tenho falado muito no tema da promoção e agora estou muito feliz, porque temos um Ministério falando, inclusive com uma revista que você tem que buscar... Acho que chama Promoção da Saúde."

Esta publicação, em dezembro de 2000, lança o seu quarto número, mesmo com a mudança do Secretário de Políticas de Saúde e com uma outra pessoa na Coordenação do Projeto. Com uma tiragem de 9.000 exemplares, esta tem sido enviada para todas as Secretarias Municipais de Saúde e para todos que solicitam o seu recebimento.

J.Y. "(...) Outra estratégia que nós adotamos em relação à P.S., em termos de divulgação, nós estamos apoiando algumas revistas, algumas publicações desde que tenha alguma coisa em promoção de saúde. Um artigo, um programa, uma experiência concreta. Estamos apoiando, por exemplo, a revista da Faculdade de Saúde Pública, a revista da Sociedade Brasileira de Progresso da Ciência.(....)"

Na fala acima se identificou, que além da Revista de Promoção, o Ministério tem financiado e colaborado com periódicos que tratem do tema promoção da saúde. Outro entrevistado nomeou outros periódicos que estão veiculando o tema no periodo estudado.

P.B. “Ah! Sim. Muito importante! Nós estamos lançando agora junto com a Cecilia Minayo, que é a editora da revista da ABRASCO; junto com a Zulmira Hartz, que é a nossa vice-diretora, nós estamos editando um número especial da revista da ABRASCO sobre Saúde e qualidade de vida, onde eu tenho um artigo sobre promoção. Mas, todo trabalho pega essa discussão de saúde e 
qualidade de vida, que é a discussão central. Tem um artigo de Municipios Saudáveis da Márcia. E nós estamos, na realidade, preparando, também, um livro sobre promoção de saúde, que é esse documento. E quem sabe você não escreve um capítulo da história da promoção de saúde no Brasil?"

P.B. "(...)Em 96/97 fui contratado pela OPS, para fazer uma revisão sobre promoção da saúde, desafios pá, pá, pá... relacionado com a saúde pública. Então produzi um texto junto com vários membros da escola. É o texto que usamos no curso, esse posso te dar uma exemplar.(BUSS, 1998) Ele está evidentemente na forma de apostila e tem partes em português e partes em espanhol. Porque ele foi feito para ser traduzido. Então tudo que eu podia colocar em espanhol porque estava sendo feitas como referência eu mantive, favorecendo o tradutor. Para, também, as referências não serem re-traduzidas para o espanhol. Então eu estaria mentindo que o cara disse aquilo e não disse.(....)"

Foi disponibilizado, em novembro de 1999, um site do Projeto na Homepage do Ministério da Saúde, na Internet, para a divulgação de informações e conteúdos da Revista de Promoção da Saúde. 


\section{4 . Organização de Eventos e Fóruns de Discussões}

Vários pesquisados relataram a importância da realização de eventos referentes ao tema como forma de difusão e estratégia para dar concretude às propostas da promoção da saúde.

No período da realização desta pesquisa foram realizados vários eventos e encontros com o tema de promoção da saúde ou relacionados a ele. Esta pesquisadora participou de vários deles, espaços estes utilizados para realizar entrevistas, obter documentos, trocar referências e fazer o registro de dados pertinentes ao estudo.

Percebe-se que, alguns docentes do Departamento de Práticas da Faculdade de Saúde Pública da Universidade de São Paulo, no qual a autora deste estudo se insere, têm investido nas potencialidades que este referencial oferece. Eles têm organizado vários eventos com esta temática, como os exemplificados a seguir.

No período de 16-19 de setembro de 1997, aconteceu um seminário* com o tema: Promoção em Saúde. Este teve como professores convidados Gordon MACDONALD e Damian DUNN, ambos pesquisadores do Reino Unido, que desenvolveram atividades teórico-práticas abordando os seguintes assuntos: Promoção em Saúde: passado e futuro; Prática da Promoção em Saúde no Reino Unido; Planejamento para a Saúde; Abuso de Drogas e Jovens Adultos; Difusão de Inovações; Promoção em Saúde Mental; Artes Criativas e Saúde Infantil.

\footnotetext{
* Seminário realizado sob a coordenação da professora Nelly M. F. CANDEIAS
} 
Deste seminário, também, participaram várias organizaçōes governamentais e não governamentais com relatos de experiências, que estavam ali sendo identificadas como de promoção em saúde. Nesta ocasião, a professora Márcia WESTPHAL, que foi a representante do Brasil na IV Conferência Internacional de Promoção em Saúde, apresentou a Declaração de Jacarta.

Entre os dias 2 e 3 de abril de 1998, aconteceu o "Workshop Promoção em Saúde". Este teve como objetivo discutir uma proposta de curso de Especialização em Promoção de Saúde. Foram apresentadas as disciplinas com os seus respectivos conteúdos temáticos e foi solicitada a colaboração dos participantes visando o aperfeiçoamento da proposta. Várias organizações governamentais e não governamentais apresentaram projetos e experiências que foram denominadas de promoção em saúde. Ao final, se explicitou que o workshop visava, também, divulgar o curso junto às instituições para que elas o indicassem para seus profissionais.

P.B. "(...)Propusemos ao Yunes e ele aceitou, organizarmos uma I Conferência Nacional de Promoção de Saúde, no ano que vem, lá em Brasília e a escola se ofereceu como secretaria executiva. Antecedendo a Conferência do México, que vai ser a próxima internacional. Mas, ai para fazer, realmente, uma exploração, fazer um estudo exploratório, levantar experiências bem sucedidas, botar essas experiências na rua, fazer uma feira da promoção, ou seja, fazer uma conferência no espirito da promoção da saúde."

Esta proposta de conferência foi viabilizada e realizada com o nome de I Fórum Nacional de Promoção da Saúde. Realizado em Brasília, no período de 27 a 29 de outubro de 1999, teve como público: prefeitos e secretários 
municipais, gestores estaduais, universidades e demais interessados. $\mathrm{Na}$ conferência de abertura do Fórum, vários se pronunciaram e deram destaque ao objetivo deste: que deveria ser o de cada vez mais se aproximar e definir melhor o que se entende por promoção da saúde; resgatar experiências que vão em direção ou que estão muito próximas deste conceito, como explicitado na relação de objetivos da programação deste, que inclui a apresentação de experiências de Municípios Saudáveis, experiências de Município Amigo da Criança, de Ambientes Saudáveis, projetos de outros setores para o Desenvolvimento Local Sustentável e o debate das principais linhas de ação da Promoção da Saúde do Ministério da Saúde.

Outro evento realizado com representantes, principalmente das secretarias de saúde estaduais, das diferentes regiões brasileiras, foi a I Oficina de Promoção da Saúde no SUS. Aconteceu em Brasilia, no dia 17 de maio de 2000. Promovida pelo CONASEMS em parceria com o Ministério da Saúde envolveu menor número de pessoas que o I Fórum e incluiu na sua programação, além das apresentações, o desenvolvimento de grupos de trabalho. Estes receberam um roteiro de questões visando favorecer a discussão em grupo. Técnicos do Ministério da Saúde e assessores do CONASEMS fizeram as seguintes exposições: Atenção básica e a promoção da saúde; Municipios Saudáveis e a promoção da saúde; Intersetorialidade e a promoção da saúde. Na segunda parte do evento foram apresentadas as experiências: Indústria Saudável; Pesquisa realizada em municipios Brasileiros; Angra dos Reis - Agenda 21 no âmbito municipal e Plano de Trabalho do Municipio Saudável - Piancó/PB. Ao final, foi apresentada uma plataforma do CONASEMS para a área.

O Congresso Nacional dos Secretários de Municipais de Saúde, desde 1998, tem inserido na sua programação o tema Promoção da Saủde 
J.Y. "CONASS e o CONASEMS sempre têm colocado este tema para discussão."

P.B. “(....)No Brasil, eu falei o ano passado no Congresso Nacional de Secretários Municipais sobre 'Cidades Saudáveis'. Foi muito rápido, mas ali foi um recadão.(....)"

P.B “(....)A revista do Ministério eles lançaram em uma conferéncia aqui do CONASEMS. O CONASEMS está com um grande projeto de municipios saudáveis tocado por Luiz Odorico, que eu acho que você deve ter uma entrevista com ele."

O entrevistado acima sugerido, reconhecido "entusiasta da idéia de Cidades Saudáveis", realmente, contribuiu bastante para este estudo, pois possibilitou estabelecer conexões de pessoas e acontecimentos relevantes e relatou informações dos "bastidores" destes eventos organizados pelo CONASEMS. (FIOCRUZ 2000)

Segundo ele (depoimento relatado no tópico 6.2.7.), o CONASEMS assume a discussão da promoção da saúde em 1995, por ocasião do Congresso de Secretários Municipais da Saúde das Américas, realizado em outubro, na cidade de Fortaleza.

A entrevista Sônia Terra Ferraz, fala deste trabalho de articulação que realizou dentro do CONASEMS:

S.F. "Nós fomos subindo, fomos abrindo as portas...Washington, no Canadá. Trouxemos cinco canadenses pra Fortaleza. E foi ai que se estabeleceu esse contato da Rede Quebequense das Cidades Saudáveis, porque eu já tinha contato com as pessoas.(...) E, ai em 95, foi quando... Ai foi quando eu senti 
que realmente, que havia uma semente a se plantar e que era no CONASEMS Que seria aqui realmente..."

Evidencia-se, mais uma vez, que o Canadá é o país que tem servido de referência e intercâmbio de experiências para a entrada da promoção da saúde no Brasil. A OPAS, também, esteve presente na organização deste evento.

O entrevistado João Yunes, anteriormente citado na articulação da OPAS com o município de Campinas, desempenha mais um importante papel na mediação dos "brasileiros" que buscavam o suporte ou apoio de um importante Organismo Internacional. Seja através da disponibilização de seus técnicos; seja através do financiamento de atividades, a OPAS se faz presente.

Ainda no ano de 2000, no periodo de 2 a 4 de agosto, viabilizado em Brasilia pelo Departamento de Saúde Coletiva da UnB; Secretaria de Politicas de Saúde e o então Programa de Educação em Saúde do M.S. e o Fórum de Saúde OPAS/OMS/UnB, aconteceu o Seminário sobre Promoção da Saúde e Educação Popular e o II Fórum de Saúde OPAS/OMS/UnB com o tema "A educação em saúde necessária para a sociedade brasileira".

Segundo os organizadores deste, o objetivo do seminário foi

“Congregar trabalhadores da rede pública de serviços de saúde $e$ educação; trabalhadores das companhias de água e saneamento e instituições de saúde ambiental; professores, estudantes, pesquisadores da saúde e áreas correlatas, e um conjunto de instituições nacionais e internacionais, como forma de um delineamento de uma agenda para a educação em saúde necessária à atual sociedade brasileira." 
Aconteceram duas mesas redondas com temas de Promoção da Saúde, que foram: Promoção da saúde e educação popular - a educação em saúde necessária para a sociedade brasileira e A promoção da saúde na escola. Foi realizada uma conferência sobre a V conferência Internacional de Promoção da Saúde. Os apresentadores destas, na sua maioria, foram os expositores presentes nos dois eventos anteriormente citados

Outro evento, que desempenhou um importante papel na difusão do tema aqui estudado, foi o VI Congresso Paulista de Saúde Pública. Tendo como tema central Saúde na Cidade, foi realizado em outubro de 1999 em Águas de Lindóia, São Paulo. Este encontro cientifico foi identificado como uma "riquíssima fonte de informação" (FIOCRUZ 2000) para a discussão de Cidades Saudáveis no Brasil.

Na visão de XAVIER (2000):

"O VI Congresso Paulista foi marcado por algumas interessantes e pertinentes discussões de cunho semântico. Ao decidir-se por um tema recente no cenário nacional da Saúde Pública, a organização do evento já previa alguma confusão que certamente seria gerada pelo desconhecimento de grande parcela do público e pelas variadas terminologias utilizadas por grupos de diferentes setores que trabalhavam com o mesmo objeto. Assim, expressões mais recentes como 'intersetorialidade', 'terceiro setor', 'empoderamento' e outras tinham que ser exaustivamente definidas, a cada painel ou mesa-redonda. O mesmo aconteceu com expressões sobejamente conhecidas mas que necessitavam de definições mais especificas ou mesmo redefinições, em razão de novos conceitos."

Este congresso fez parte do cenário desta pesquisa, onde foram entrevistados três dos pesquisados. Ratifica-se aqui a visão do autor citado não 
só por ter presenciado os acirrados debates e conversas paralelas no transcorrer das atividades, mas, também, por ter identificado vários depoimentos que indicavam a necessidade de se investigar o que se estava compreendendo por promoção da saúde, na atualidade.

E.M. "Acho que é isso mesmo, o que é muito importante é que essas iniciativas vão e voltam, vão e voltam. Já começam as criticas. Hoje assisti uma Mesa onde se criticava cidades saudáveis. Enfim, isso é muito importante. As pessoas não estão neutras, se posicionam a favor ou contra. Sempre que estas coisas, acopladas com à OMS, à OPAS, enfim, estas instituições internacionais têm um peso. Influir."

Foi muito significativo identificar a pertinência da "pergunta de partida" deste estudo, em várias falas do Congresso. Estando na fase de pesquisa de campo, cinco meses após o exame de qualificação do projeto, renovaram-se os desafios da empreitada proposta.

Um dos participantes desta pesquisa presidiu este congresso e fala da sua influência na definição da temática do evento.

P.C. "(...)Tenho trabalhado, tenho militado numa Associação Paulista de Saúde Pública e, a partir da minha posição na diretoria, tenho proposto insistentemente que a nossa agenda de militáncia também seja por ai. Inclusive a gente tá promovendo um congresso, VI Congresso Paulista de Saúde Pública, que tem exatamente este tema, não é Promoção da Saúde, mas o conteúdo é quase exclusivamente sobre isto..."

A organização deste Congresso feita pela Associação Paulista de Saúde Pública (APSP) contou com a colaboração de algumas participantes da Oficina 
Permanente de Estudos e Programas sobre Cidades Saudáveis, da Faculdade de Saúde Pública da USP.

Coordenada pela Profa Márcia Westphal, sendo vice-diretora da FSP/USP, esta Oficina foi "criada para estimular a formulação e 0 aprofundamento teórico e conceitual relacionados ao tema." Uma das estratégias adotadas pelos participantes da Oficina tem sido a de "promover o 'encontro' entre atividade científica, de pesquisa, e a gestão, a prática de municipios." (FIOCRUZ 2000)

Estes "encontros" foram lembrados e considerados relevantes pela maioria dos pesquisados. O "grupo da USP" foi identificado nas entrevistas como sendo o interlocutor com quem os pesquisados mais trocam informações sobre a temática promoção da saúde. Para explicitar o grau de importância atribuido a este grupo foram selecionados alguns depoimentos:

V.L. "Acho que há algumas iniciativas interessantes, como, por exemplo, a iniciativa do grupo de Márcia [Westphal] e de outras pessoas interessadas em municipios saudáveis, que estão realizando este trabalho. É importante que ele seja muito divulgado. Eu acho, porque é por ai que se caminha mesmo."

J.Y. "Bom, o fato da oficina da Faculdade de Saúde Publica ter funcionado como Oficina Permanente, isso nos tem ajudado, é mais um canal de difusão do conceito. (...)A Faculdade de Saúde Publica através da Vice-Diretora, a Prof Márcia [Westphal]. Ela tem trabalhado muito nesta área, nesta direção. Através da oficina, eu faço contato com outras pessoas."

E.M. "(...) Mas, acho, também, que a Faculdade de Saúde Publica da USP, através lá da Márcia, do Fórum Permanente, que está tendo um papel 
importante de conciliar essas agendas e ver o que elas têm em comum. Acho que tem sido um fórum importante para a difusão...(....)"

Um dos três seminários realizados por esta Oficina, no ano de 1999 , tratou exclusivamente da temática acima referida - Articulação entre as agendas sociais: agenda 21 , municipio saudável, comunidade solidária e outras.

A Oficina também promoveu uma discussão das propostas de promoção da saúde do Brasil, para a ida à $\vee$ Conferência do México. $E$, realizou em outubro de 2000, um Seminário sobre esta Conferência - A Conferência do México: subsídios para a construção da agenda de Promoção da Saúde no Brasil. Contou com a presença dos representantes brasileiros que tinham dela participado. Esta participação foi avaliada e foram discutidos alguns encaminhamentos visando construir uma agenda para a promoção da saúde no Brasil. A coordenadora do Programa do Ministério, representante da OPAS, o diretor de Relações Internacionais do CONASEMS, uma representante do Ministério da Educação e Cultura e docentes da USP foram expositores neste evento.

Ao final deste Seminário da $V$ Conferência, foi realizada a assembléia de fundação do CEPEDOC - Centro de Educação, Pesquisa e Documentação de Cidades Saudáveis.

A Oficina também tem uma Lista de Discussão na Internet, que "foi criada com o objetivo de trocar experiências e informações diversas sobre 0 tem e criar um espaço de debate permanente."

Um dos entrevistados, ao descrever as atividades que tem desenvolvido na área estudada, relatou fazer parte desta Oficina e da Lista de Discussão. 
P.C. "Tenho, faço parte de uma Oficina de Estudos de Projetos de Cidades Saudáveis, mas que trabalha com este conteúdo da Promoção da Saúde e faço parte de uma lista de discussão via eletrônica que troca informações, discussões. Ela ainda está em desenvolvimento, mas começa a se relacionar para esta área.(....)" 


\subsection{Formação de Recursos Humanos nas Escolas ou Núcleos de Saúde Pública}

Outra estratégia de difusão identificada foi a de sensibilização e qualificação dos profissionais da saúde pública e de outros setores para atuarem na área de promoção da saúde.

Em agosto de 1998, deu-se início ao primeiro Curso de Especialização em Promoção em Saúde, pela Faculdade de Saúde Públical USP, com 45 alunos matriculados. Este foi oferecido com uma carga horária de 390 horas, com as seguintes disciplinas: Saúde, formas de sociabilidade e novos cenários sociais; Saúde e doença: dimensões e sentidos; Políticas públicas e fortalecimento da participação popular: Promoção de saúde nos espaços de vida; Planejamentos de programas de promoção de saúde; Fundamentos históricos e conceituais da promoção de saúde: discussão de propostas e modelos: Promoção de saúde no processo de envelhecimento e Experiências de promoção de saúde.

V.L. "(...)Então, a FSP/USP, ela tem feito um trabalho importante, tem tomado, até ocupando uma certa liderança em todo este processo."

Identificou-se também que a ENSP/FIOCRUZ já está ministrando disciplinas com esta temática nos seus cursos de pós-graduação e pretende ampliar as oportunidades de qualificação nesta área.

\footnotetext{
- Segundo informações da Coordenação de Pós Graduação da FSP/USP, até agosto de 2001, 98 profissionais concluiram o curso de especialização em Promoção da Saúde nesta instituição.
} 
P.B. "Nós temos uma função importante por sermos uma grande escola de saúde pública, por sermos do ministério e tal. Nós estamos associados ao Yunes. Primeiro o projeto com a CPHA (Canadian Public Health Association) prevê que depois do segundo ano em diante, já mais "solidozinhos", começaria com cursos, participação em eventos, seminários e difusão através da ABRASCO. Já, aí, utilizando uma plataforma mínima para que outros grupos que quisessem se preparar com a gente. Então é uma estratégia por dentro do aparelho formador.(...)"

V.L. “(...)A Escola Nacional de Saúde Publica, por exemplo, está fazendo um trabalho muito interessante nesta área de Promoção da Saúde, pela área toda da favela da Maré e a circunvizinhança da escola mesmo, que é um trabalho muito interessante, muito dentro da nossa realidade, de pessoas mais necessitadas e que reúne, integra a formação de recursos humanos, a prestação de serviços, como também a geração de trabalho e de renda. (....)"

M.A. "Tem um clima. Clima tem, inspira. Mas essa coisa de virar profissão promoção da saúde, é complicado. Engraçado, departamento... Um dia a Márcia estava me falando: 'Vamos criar um Departamento de Promoção da Saúde! É legal?' Aquele Departamento vai promover a saúde, os outros não!

D. Como isso vai favorecer a intersetoralidade que nós estamos falando..

M.A. Então é complicado, mas é de alguma forma dar a visibilidade à questão da Promoção. A promoção enquanto uma prática especifica não é mais um Departamento de Práticas, tá bom, um Departamento de Promoção, mas ainda vai ter o Departamento Materno Infantil, Departamento de Nutrição, como é que a promoção perpassa, isso aí é mero exercicio teórico." 


\section{CARACTERIZAÇÃO DO MOVIMENTO DE PROMOÇÃO DA SAÚDE NO BRASIL}

Ao iniciar esta pesquisa, acompanhando a crescente discussão em torno desta temática no interior da Faculdade de Saúde Pública/ USP e, depois, participando de vários eventos e cursos, reconheceu-se uma crescente preocupação de vários profissionais da saúde pública em difundirem alguns projetos, circularem bibliografias e "contagiarem" mais pessoas para aceitarem o desafio da operacionalização do referencial da promoção da saúde, no Brasil.

Investiga-se, nesse momento, a opinião dos participantes deste estudo sobre o movimento do qual fazem parte. Com este interesse, perguntou-se aos entrevistados se estes consideravam que o movimento de promoção da saúde, no Brasil, poderia ser considerado um movimento social.

Aliás, a um dos entrevistado nem foi preciso perguntar, pois, nos primeiros minutos da entrevista, apresenta essa idéia:

P.B. “(...)Eu acho que a promoção de saúde hoje, considero ela um movimento social com repercussões e com laços no setor saúde muito importantes. Obviamente, com o sistema de saúde também

D. O Sr. pode falar mais um pouquinho por que o $\mathrm{Sr}$. considera que é um movimento social?

P.B. "Porque, embora, digamos assim, as bases politicas e técnicas sejam formuladas por técnicos do setor saúde, ela propõe e, eu acho que existe resposta social pra isso, ela propõe isso. Existe resposta social para que a questão da saúde seja tomada por outras forças da sociedade, outros grupos 
de interesse. Por exemplo: as mulheres; quem trabalha o tema da Agenda 21, que considera muito. Então, eu faço uma distinção importante da promoção da saúde e o resto do campo da saúde. Agora, eu não vejo a promoção da saúde, e, por isso que acho ela cada vez mais como um movimento social, como alguma coisa dirigida à melhoria, reformulação de hábitos de vida. Não se restringe a isso. Eu acho que isso é um componente importante da promoção e da educação da saúde, indelegável e que também não é uma tarefa só do setor saúde. É uma tarefa cada vez mais na mão dos jornalistas, dos vários suplementos dominicais, sobretudo. (...)Eu entendo a promoção da saúde, o que mais me interessa, é a que trabalha focando os determinantes da saúde em caráter mais estrutural. Eu acho que as funções de "advocacy", mediação, capacitação. Acho que a promoção da saúde pode agir no plano estrutural e isso é que moveu inclusive politicamente, e quando eu movo não só tecnicamente, me movo como pessoa, politicamente, na direção da promoção da saúde. Ai estou sendo não um técnico, mas estou sendo, na verdade, parte de um movimento social. Inclusive como militante desse movimento, eu fico muito impressionado. Tenho dito em minhas aulas, posso depois até mandar para você esse roteiro."

J.Y. "Eu acho que sim, primeiro porque a participação social é fundamental no conceito de promoção de saúde.

D. O Sr. já vê isto hoje nestas experiências?

J.Y. Já, já. Segundo, como eu coloquei, Municipio Saudável é um movimento. Em sendo um movimento intersetorial é um movimento social. Dentro dos profissionais de saúde esta concepção tem... 'contaminado' muito, no bom sentido, os profissionais de saúde."

[Pausa: interferência de som, serviço de alto-falante do Hotel convocando pessoas.] 
D. "Então, o movimento da promoção da saúde, no Brasil, pode ser classificado como movimento social?

J.Y. Sim, como eu estava explicando, Município Saudável é um movimento. Então, este movimento envolve prefeito, a câmara de vereadores, a organização da sociedade."

A intersetorialidade aqui é associada a uma visão de atuação integrada do Estado, sociedade civil e movimentos organizados e, não, apenas, enquanto sinônimo da interação de saberes das diferentes áreas de conhecimento saúde, educação, meio ambiente, política, comunicação, entre outros,.

O principal argumento apresentado, nos depoimentos abaixo, para a não identificação deste movimento como um movimento social se fundamenta nas caracteristicas de seus participantes, descritas pelo entrevistado, anteriormente, citado. Segundo eles, os envolvidos são, predominantemente, do setor saúde e, ainda, em pequeno número.

P.N. "Ele ainda é segmentado ainda, como a gente discutiu aqui. Ele ainda está restrito a algumas cabeças. Está no domínio de algumas universidades, de algumas autoridades, mas ele não está na população.(...)"

V.L. "[Silêncio] Eu ... tenho ... impressão que ... ainda... não. Um movimento social que seja assim reconhecido pela maioria das pessoas. Eu acho que é alguma coisa que está começando a acontecer. Eu acho que está começando... Você veja, por exemplo, eu estava considerando de 1996, para cá, são três anos.

(...) O que eu quero dizer é que, eu não vejo, eu, pessoalmente, a promoção, ainda, empolgando um grande contingente de profissionais. Eu acho que é um processo que está, atualmente, sendo construido. Que seja significativo, que 
tenha uma certa força. Eu acho que é alguma coisa que está sendo construída gradualmente. Eu acho que quem está, por exemplo, uma instituição que está dando um grande passo neste sentido é a FSP. Eu acho que a Escola Nacional de Saúde Pública, também, está dando uma contribuição importante através do seu trabalho, de seus cursos das disciplinas que criou nesta área. Mas, eu acho que é importante que este processo adquiria uma força maior. Não é o conjunto de sociedade que eu estou esperando, aguardando não ...."

O depoimento a seguir introduz um aspecto inédito neste estudo: o interesse ou o crescimento do interesse do setor privado pelo referencial da promoção da saúde. $O$ entrevistado que apresenta este fato, além de atuar na área de saúde pública orientada pela lógica do público, trabalha para uma instituição governamental que segue a lógica do privado.

M.A. "Em 97, eu retornei um pouco à gestão, era uma proposta da CASSI (Caixa de Assistência da Saúde dos Funcionários do Banco do Brasil) de um plano autogestão. Eles estavam com uma proposta de promoção da saúde. $E$, aí, eu passei nesse concurso e virei Coordenador de Saúde nessa Caixa. Então, é onde eu estou, desde 97, desenvolvendo o projeto na área de promoção da saúde ligado à população de bancários."

A partir dessa experiência, ele, ao ser perguntado se o movimento de promoção da saúde poderia ser considerado um movimento social, afirmou:

M.A. "Não identifico, não vejo isso na sociedade. Vejo isso como instrumento, as empresas de mercado usando isso como nicho de mercado, entendeu? De uma forma ocupando nichos, identificando necessidades. Não vejo movimento social da Promoção, não vejo não." 
Este interesse em "lucrar financeiramente" com a difusão da promoção, foi apresentado por outro entrevistado que também atua no setor privado, como um desvio das propostas deste referencial:

V.P. "E, por outro lado, surgem alguns desvios, que são mais ou menos esperados, mas que a exploração da idéia é no sentido de tentar vender prevenção para a população. Dou um exemplo interessante nisto aí, na nossa área original que é a odontologia. Aonde os profissionais começam a tentar vender promoção da saúde para os seus pacientes e vender prevenção, serviços preventivos. (...) Os profissionais começam a ganhar dinheiro vendendo a manutenção da saúde. Então, surge uma barbaridade, que é a manutenção da saúde. De certa forma é correto, lógico que é correto você ajudar as pessoas a manter sua saúde, só acho que não deveria.... Os ingleses, agora, estão com uma discussão interessantíssima sobre isto. Dizem: "não pagamos profissionais para cortar ou limpar as nossas unhas, porque teriamos que pagar para limpar os nossos dentes?" Essa é uma discussão fantástica..."

Dentro dos contornos estabelecidos para este estudo, é impossível aprofundar esta discussão. Registra-se, assim, que o interesse pela difusão da promoção da saúde, no Brasil, não é orientado, somente, pelos valores humanitários da proposta. Esta questão constitui campo fértil para novos estudos na área.

Uma das entrevistadas considerou que, no Brasil, este movimento não se configura como movimento social, mas que internacionalmente sim. Outros dois julgaram que o movimento brasileiro tende a se tornar um movimento social, conforme se observa nos trechos de entrevista abaixo selecionados:

S.F. "Eu acho que sim no nivel internacional, não no Brasil. No Brasil eu acho que ainda não. No Brasil eu acho que é uma coisa que ainda está muito no 
início. Consideraria no Brasil, talvez um salto qualitativo do movimento da saúde [sanitário] e não um movimento de promoção da saúde".

P.N. "Mas ele chega lá [O movimento chega a movimento social]. Ele existe lá, ele existe, estão falando de alguma forma. Na medida em que não tem terra para as pessoas, não tem moradia, que a violência aumenta, eles estão com raiva da violência, estão com raiva do desemprego, mas é porque eles não estão canalizando aquilo lá pra resolver. $E$, isso, num país, como nosso, imaturo, digamos assim, democraticamente. Passou vinte anos de cadeado, as pessoas ainda não têm a prática de viver com isso. Isso é muito fértil pra o demagogo, pra aparecer prometendo coisa fácil, soluções facilimas. Então, até a gente teve um engodo recente agora, fruto de um "messias" que chegou ai dizendo que ajeitava tudo, coisa que a gente sabe que dentro de 50 anos não é possivel, realmente, resolver. Se começar de ontem. (...)"

L.A. "Eu acho que no Brasil ainda é muito incipiente pra você dizer... Acho que seria, digamos, muita pretensão, dizer que sim. Movimento social, das massas, mobilizar... Acho que é um conjunto amplo de pressão da sociedade. Acho que ainda é uma idéia-força que está se articulando, que está se construindo como um espaço do que seja um Movimento Social. Acho que é uma idéia-força, que tem tudo pra articular: um grande Movimento Social com Promoção da Saúde sistematizada. Por exemplo, se você avaliar, o Movimento Sem-Terra é Promoção da Saúde. Aí você pode dizer que o Movimento Sem-Terra é um movimento social. Se você avaliar que a questão do meio ambiente é a Promoção da Saúde, o Greenpeace é um Movimento Social. Agora, até você chegar a conclusão de que a luta do Movimento Sem-Terra é uma luta de Promoção da Saúde, depende desse conceito abrangente que a gente está dando aí. Se você trabalha na construção de grandes consensos, digamos, da melhoria de qualidade de vida, de garantia dos direitos sociais, da democratização da sociedade, ai você tem grandes movimentos sociais. A 
Promoção da Saúde como bandeira, digamos, como uma estaca, ainda, não sei se isso configura assim."

Os três últimos depoimentos citados introduzem uma questão que teve que ser formulada para os entrevistados:

D. "O que identificaria pra você movimento social? O que você entende pur movimento social?

M.A. "Massa, divulgação, objetivo, luta, conflito. Movimento social, como movimento da promoção da saúde... Como é que aquela moça que tá ali poderia incorporar o movimento social da promoção da saúde? O que é que ela tá lutando, aquela moça ali da portaria? Eu vejo... Talvez se ela for demitida... O movimento dos desempregados... Os desempregados estão, está se tornando, às vezes, um movimento social. Sem-terra é movimento social. Outro movimento social que a gente tem no Brasil... movimento dos insatisfeitos contra o governo Fernando Henrique; os empresários paulistas. O movimento dos caminhoneiros, pode ser até de partido, circunstancial, conjuntural, mas é um movimento social. Como é que você vê o movimento da promoção da saúde? Um movimento social, não!"

V.L. "Eu vou te dar uma definição que não é nada ortodoxa não. Mas eu acho que movimento social pressupõe a reunião de um grupo de pessoas em torno de determinadas idéias e propósitos. $E$, que têm objetivos comuns ... E, eu imagino, que este movimento, para que ele se constitua com a força de um movimento social maior, ele precisa de todo um processo de amadurecimento. E eu acho que ele não se constitui de uma hora para outra. Eu acho que é preciso que exista reflexão, que exista experiência, que exista idas e vindas, para que aquilo, que amadureça como movimento mesmo." 
A direção apontada pela entrevistada acima, com a finalidade de favorecer que o movimento da promoção da saúde aumente o seu potencial de mobilizar e reivindicar transformações necessárias na realidade brasileira, é compartilhada por um outro entrevistado, no depoimento a seguir:

I.C. "(...)Mas a estratégia central ainda precisa ser construida, vamos dizer assim. Nós precisamos construir uma idéia nacional, um projeto nacional de promoção da saúde, onde nós não só tenhamos a visão de algumas pessoas, de alguns 'iluminados', de alguns 'esclarecidos'. Mas, sim, uma coisa que possa ser construida e ser abraçada pelo conjunto da saúde e pelo conjunto da sociedade. Para que nós construamos alguns pontos, alguns consensos que possam ser, digamos, trabalhados não só pela saúde, mas por vários campos ao mesmo tempo como forma de potencializar essas ações."

D: Acho que a formação de pactos então me parece. Pactuar ações e problemas?

I.C. "Exatamente, essa construção desse projeto é uma das metas nossas, um dos objetivos, é o processo de construção de um pacto em torno de alguns temas e em termos de alguns objetivos. Algumas questões consensuadas de que trabalhadas e trabalhadas em um conjunto, não só pela saúde, mas por um conjunto mais expressivo de setores pudesse resultar em uma vida mais longa e de melhor qualidade."

Não existe uma visão univoca entre os entrevistados sobre a proposição de que o setor saúde deve assumir a liderança e convocar outros setores ou segmentos da sociedade visando a superação das desigualdades da realidade brasileira. Na verdade, nos dois próximos depoimentos, são apresentados elementos que questionam a factibilidade dessa atribuição conferida a este setor. 
V.P. "Não. Para se chamar de movimento social ele é algo que já deveria teria adquirido a força e o volume de algo significativo. Então, a área de saúde, em geral, é uma área secundária, algo de pouco significado não só dentro do orçamento governamental como, também, para as cidades e população de certa forma. Porque, essa não é a preocupação principal do indivíduo.

Houve um periodo que fiz um diagnóstico, onde tive a oportunidade de conhecer o Estado de Sergipe. Então, fiz um levantamento das necessidades das cidades locais, isso foi há uns 7 anos, e, raramente, aparece a necessidade de saúde. Necessidades fundamentais estão ligadas a: reforma de habitação, iluminação, calçamento, enfim, uma serie de necessidades que são superiores. Às vezes, aparece uma necessidade maior quando um profissional do setor... que dá certo valor nesta questão. Na política geral do país o que comanda é a economia. O que é democrático, que tem discussão são as qualidades sociais saúde principalmente, educação. Mas, a área económica, totalmente centralizada, completamente fechada, sem discussão nenhuma e decisões tomadas da noite para o dia. Todo o capital do pais é envolvido sem a participação da população. E, essa é a área fundamental, nós andamos de acordo com o sabor da economia internacional. Então, a promoção da saúde está muito longe de ser um movimento. Apesar de dedicarmos nossa vida a isso."

E.M. "Eu creio... Não sei... Acho que não, é cedo... É isso que eu te falei.. O desenvolvimento da promoção da saúde ele é muito corporativo, ele vem da área de senviços de saúde. A área de serviço de saúde ela tem baixo poder estruturante. Um projeto de Promoção de Saúde frente, por exemplo, a um problema de adolescente; a um problema ambiental; a um problema educacional, que têm altíssimo poder de estruturação. Então, por exemplo, eu não sou muito favorável que tenham Secretários de saúde induzindo Movimentos de Cidades Saudáveis. Eu acho que isso é um equivoco louco." 
D. Qual então é a finalidade da saúde então?

E.M. "É serviço de saúde, mas não tem nada a ver com um movimento. Por que - Secretário de saúde é que vai ter o poder de convocatória pra mexer na cidade inteira? Não, quem tem que fazer é o Prefeito ou um Secretário de Planejamento ou de Governo, que tem a coordenação conjunta do Governo. Mas nunca o Secretário da saúde. Eu acho isto um equivoco tremendo. Portanto, eu não reconheço este Movimento Social de Promoção da Saúde. Gostaria muito que esse conjunto de idéias, chame-se... Todas essas agendas sociais confluissem pra isso, ainda que cada uma mantendo sua identidade, seus pontos de entrada que são diferentes, seus poderes de especificidade, sua capacidade de estruturação são muito distintas.

D. Enquanto o poder de reivindicar, e convocar e estar saudável associado sempre a essa...

E.M. "Esse conceito estrito de saúde, como serviço de saúde. Esse é um problema comunicacional seríssimo. Outro, é isso: como é que nós anticulamos na agenda da cidade saudável a ampliação do capital social, do capital produtivo e do capital humano no conjunto. Então, essa é a dimensão de desenvolver sustentadamente através de cadeias produtivas, micro-regionais, a sustentabilidade económica, isso é um outro ponto que eu sinto muita falta. Terceiro, uma estratégia de mobilização social, enquanto estratégia de intervenção, de no sentido de aumentar o capital social.

D. Poder associativo, acreditar na ajuda mútua... 
E.M. E pra isso você precisa ter estratégia de mobilização social. Nós somos muito amadores. Então, acho que esse é um buraco muito grande. Acho que é um obstáculo, sem dúvidas. Há outras, precisava pensar um pouco mais".

Analisando o conjunto dos depoimentos, pode-se afirmar que a maioria não vê o movimento de promoção da saúde, no Brasil, como um movimento social. Ainda, não há consenso entre eles, ou melhor, nem todos concordam com a visão de que, através da mobilização social desencadeada pelo setor saúde, um dia este possa vir a ser.

Fazendo o paralelo com a entrada da promoção da saúde em um outro pais, foram encontradas semelhanças. CERQUEIRA (1997) comentando a análise de PEDERSON, O'NEILL e ROOTMAN sobre a experiência da implantação da estratégia de promoção da saúde no Canadá conclui:

"(...)a promoção da saúde na província de Ontaro, Canadá, como movimento social, foi levado a cabo por intelectuais, profissionais de saúde que usaram seus conhecimentos, preparação acadêmica, habilidades técnicas e empregaram as técnicas de 'advocacia' para questionar a educação para saúde oficial da época, assim como o modelo médico e os serviços de saúde."

A população e outros movimentos sociais não estão incluídos enquanto sujeitos históricos que participaram da construção da prática de promoção da saúde naquela provincia. $O$ olhar $e$, consequentemente, os interesses vigentes são os dos técnicos da saúde.

Não se defende aqui que os técnicos não devam ter propostas, na realidade, considera-se muito importante tê-las. O que não se quer, é repetir "práticas discursivas e institucionais do campo da saúde" que, no passado 
recente, pretendiam um "vir a ser" para a população que não considerava o que esta queria. (CARVALHO 1997; BECKER 1986) 


\section{SETORES RESPONSÁVEIS PELA IMPLEMENTAÇÃO DAS AÇÕES DE PROMOÇÃO DA SAÚDE NO BRASIL.}

Um dos objetivos deste estudo foi identificar a quem os documentos e os entrevistados se referem, direta ou indiretamente, para implementar as ações de promoção da saúde (questão 15).

Os setores mais citados para a implementação das ações de promoção da saúde foram aqueles mais diretamente ligados às politicas sociais: saúde, educação, meio ambiente e/ou saneamento, previdência e/ou ação social. As opiniões dos entrevistados se diferenciam quanto ao grau de importância atribuido a um ou outro setor.

$\mathrm{Na}$ Carta de Ottawa, mesmo anunciando que a promoção da saúde requer a ação coordenada de todos os setores, destaca-se que esta é uma "responsabilidade maior do setor saúde".

Apenas um dos entrevistados reportou-se à visão do documento de Ottawa.

I.C. "Vários desses objetivos não vão ser conseguidos por uma área especifica, por um setor de promoção da saúde ou de um projeto de promoção da saúde ou, mesmo, pela atuação isolada da saúde. Nós temos um trabalho fundamental que é ir construindo na sociedade um conceito de um lado e, por outro lado, desenvolver um conjunto de instrumentais para que ela possa resolver alguns problemas, para que ela possa atingir determinados objetivos. Ai, em especial, pensando a questão da inclusão social, a saúde pode atuar 
como um formulador disso, como um estimulador da luta social para se conseguir mais equidade. Essa é uma forma de operacionalizar. O sucesso e o insucesso disso não vai depender só da promoção da saúde, obviamente. Nós [saúde] somos um campo fundamental para trabalhar isso. Nós constituímos um campo que pode trabalhar intensamente na sociedade, que não é legitimo haver pessoas que não têm a mesma longevidade ou uma determinada qualidade de vida porque não têm garantias minimas de alimentação, de educação, de lugar adequado e confortável para viver. Podemos trabalhar nesse sentido, mas isso deve ser assumido pela sociedade como um todo pelos governos e pela sociedade."

Observa-se, no depoimento acima, que a regulação ou a responsabilidade deve ser compartilhada, mas se atribui ao setor saúde o poder de convocar ou sensibilizar para a ação.

As potencialidades das parcerias entre educação e saúde, são anunciadas por vários entrevistados. Desses, três abaixo citados enfatizam a relevância do setor educacional. A capilaridade ou a grande interface que estes dois setores têm, cotidianamente, com a população é apontada como uma condição que favoreceria o planejamento e implementação das ações de promoção da saúde.

V.P. "Você tem áreas que são fundamentais como a educacional. Os programas sociais clássicos são as quatro áreas: de educação, de alimentação, da previdência social e a atividade de saúde. A área da educação é que tem se destacado mais. A tendência é de que as pessoas tenham uma renda cada vez mais mínima para sobreviver. Pelo lado da previdência social não temos condições de avançar, uma vez que o setor de previdência social está, cada vez mais, sendo privatizado. Não se imagina, até o momento, que vai se conseguir avançar embora o governo gaste muito neste setor. A alimentação é 
um setor social fundamental, mas o que tem ajudado mais, é o da educação. $(\ldots)^{\prime \prime}$

P.N. "Historicamente, a questão é mais, diretamente, ligada à saúde, mas a educação não pode nunca ficar fora. O Ministério da Educação já era para ter essa consciência, porque temos um potencial incrivel. Temos, em cada cidade, no mínimo, a metade da população entrando e saindo da sala de aula todo dia. Isso é uma oportunidade enorme para que essas pessoas possam entrar em contato e ter noção dessas coisas [prevenção, promoção]. Então, a capilarização dessa noção, a difusão dessas idéias mediante o currículo é fundamental. A educação está totalmente alheia, salvo por iniciativas isoladas de algumas cidades e projetos. Nós e alguns outros prefeitos temos uma preocupação com essa questão, mas, ainda, não é uma política de governo do Brasil como um todo. A própria Faculdade de Medicina trata de doenças, e de algumas doenças especificas que considera que tem que tratar. Já, deveria estar dando uma noção maior para aos alunos. O médico já sai de lá distorcido."

L.A. "Acho que a Academia tem um papel importante, porque existe nosso ponto de vista: de elaboração, de formulação. A Academia, as Universidades dão uma contribuição para isso.(...)"

Evidencia-se, no último depoimento, o papel que a academia (ensino formal) tem na atualidade. Na opinião do entrevistado, faz-se necessário, operacionalizar e avaliar as tentativas de implementação das ações de promoção da saúde, no Brasil. Observa-se que o comentário feito sobre o "nosso ponto de vista", refere-se à necessidade do Brasil testar as possibilidades dos enunciados da promoção da saúde, considerando a diversidade dos municipios e regiões. A avaliação das experiências de promoção da saúde, que estão em curso, em diferentes lugares do país, requer 
a formulação ou adaptação de indicadores ou critérios que foram utilizados em outras realidades. $O$ aprofundamento das discussões, que são introduzidas nos documentos internacionais, é, também, outra indicação ou recomendação para o ambiente universitário.

A mesma relevância, anteriormente, atribuida à academia ou aos centros universitários, nota-se nos depoimentos a seguir:

S.F. "(...)Uma coisa que me anima muito é ver todo esse interesse da academia, dos estudantes porque acho que quanto mais reflexão houver, quanto mais pesquisa e estudo houver, quanto mais interesse houver, mais nós vamos ter clareza e vamos poder pensar melhor como resolver os problemas...(...)."

A.V. "Olha Dais, eu posso the dizer que dentro de tudo que conversamos, um ponto que é necessário realçar, colocar numa dimensão maior, é esta preocupação que tenho com vocês pós-graduandos. Estou extremamente grato... [risos] por, particularmente, ter um papel na sua tese. Porque para mim isto significa sangue novo, mentalidades novas, que vão trabalhar pensando nestes propósitos. Nós que já estamos na fase de ir embora... [risos] Vocês estão na grande vertente de produzir, que se dediquem à Promoção da Saúde. (...)Dediquem-se ao conceito maior de saúde, com o bem estar, com seriedade. Tem que ser formado aquilo que você disse... 'um ideário pela saúde'. É algo importante, isto é, diz respeito ao que lhe falei antes, que daqui a algum tempo estaremos trabalhando com um outro cenário. Vamos estar discutindo condições de vida, quiçá, como melhorar os aspectos dos fatores positivos, digamos. tocar na parte da resiliência. Todos são aspectos que, todavia, estão na pasta [agenda], que têm que ser olhados para que passem ao plano da atenção ou da prioridade.. 
Acho que o ponto maior para mim, especialmente, é esta preocupação com o mundo acadêmico, com a nova mentalidade dos jovens médicos, com a qualidade dos jovens médicos... Desculpe estar falando só nos médicos. Mas, com os jovens preocupados com a saúde, que estão fazendo suas teses, seus trabalhos. É um mundo fascinante, muito interessante, mas que exige, também, responsabilidade. Exige responsabilidade nossa no sentido de desenvolver, dar valor, agregar valor para que seja ... aquilo que falo, seja valor no cotidiano."

Nos depoimentos acima fica evidente a importância atribuída à formação de recursos humanos e à renovação do quadro dos profissionais da saúde. Espera-se que os egressos destes cursos atuem sensibilizados e preocupados com a operacionalização do conceito e dos ideários da promoção da saúde. Essa foi uma das estratégias identificadas, neste estudo, para a difusão desse conceito, no Brasil.

A nova mentalidade, na opinião do entrevistado, se fundamenta em uma visão de saúde que vai além do conceito desta enquanto resultado das condições concretas de vida, ou, tão somente, em termos da classe social, do gênero, da origem étnica, da ocupação ou do acesso aos serviços. A nova visão se fundamenta em uma concepção de saúde enquanto um recurso subjetivo e objetivo, que as pessoas contam ou recorrem frente às dificuldades, em situações adversas ou nos desafios da vida. Portanto, os profissionais devem se ocupar, também, em estudar ou atuar junto àqueles que têm resistido ou têm capacidade de oferecer respostas ou buscar alternativas mesmo nas adversidades. Isto é, devem aprender com os que têm resiliência. (ALVAREZ, 1999)

O meio ambiente surge sob duas concepções: associado ao saneamento e constituindo, também, um setor em separado. Nos depoimentos abaixo. são 
apresentadas justificativas para a inserção dos problemas desta área na agenda da saúde:

V.P. “(...) A área de saneamento está ligada, está dentro da saúde. Dar água potável para as pessoas é fundamental pois resolve o problema das doenças básicas. A estratégia, agora, utilizada para diminuir a mortalidade infantil, e aquelas doenças transmitidas pela água, tem sido um bom saneamento básico. (...)"

I.C. "Trabalhar saneamento e meio ambiente é questão fundamental para a gente também. Temos muito a contribuir para com esses dois setores. A partir do momento que a saúde abandonou o saneamento ou que delegou a outros setores a tarefa de garantir saneamento para todos, somando-se a esse fato, determinados rumos que o Estado brasileiro tomou, não favoreceram essa questão. O saneamento é uma questão crítica. Hoje, o número de brasileiros que não tem água adequada para consumo, não tem o tratamento adequado de lixo e dejetos é assustador. Então, devemos pautar esta questão para valer, novamente; inclui-la na agenda da saúde como objetivo a se buscar(...)"

S.F. "(...)Você pega saúde, educação... Até hoje a formação dos profissionais de saúde está no Ministério da Educação, mas, não há este entrosamento. Saneamento está fora da saúde. O meio ambiente não é pensado em conjunto. Por exemplo: esta coisa que está agora no Congresso, do desmatamento, da Lei Florestal. A saúde não toma parte desta discussão. Ontem mesmo, recebi, no meu correio eletrônico, vários documentos, porque tenho muita afinidade com pessoas do meio ambiente e de ecologia. Em Rondônia está acontecendo desmatamento, $50 \%$ do território a ser desmatado. Você pega a conseqüência disto para saúde: as endemias - febre amarela, dengue, difteria. Isso ai é terrivel e nós, na saúde, não tomamos conhecimento. Estamos preocupados ali com o dia a dia, com a estruturação do SUS, com a assistência.(...)" 
As preocupaçōes manifestadas pelo entrevistados estão presentes nas declaraçōes das Conferências, sendo que mais, explicitamente, nas de Adelaide e Sundsvall. (MINISTÉRIO DA SAÚDE 1996) Nestes depoimentos, foram dados muitos exemplos da relação que as politicas de saúde e de meio ambiente e/ou saneamento estabelecem entre si, na determinação da qualidade de vida da população.

A proposta de articulação de agendas, sugerida nos depoimentos e documentos, visa aproximar as preocupações do movimento de promoção da saúde dos temas e estratégias presentes na discussão do movimento ambientalista ou ecológico. A partir daí, espera-se que a conjugação de recursos e esforços possa imprimir novas práticas de atuação junto à população. Este encontro, também, introduz novos termos no discurso da saúde. (DOORIS 1999) Entre eles, pode-se citar: sustentabilidade das ações, políticas e recursos sustentáveis, Agenda 21 da saúde, saúde sustentável etc.

A crescente urbanização da população brasileira é um dos fatores que aceleram as desigualdades no acesso aos vários serviços. As declarações de Sundsvall e Jacarta sinalizam os problemas que advêm deste processo e exemplificam, como consequência, a falta de água potável e saneamento básico. Estes fatos foram várias vezes citados pelos entrevistados. A atual crise energética, na qual vive o país e os racionamentos impostos, confirmam os anúncios de que os recursos naturais são esgotáveis e, muitos deles, não renováveis.

Os entrevistados, nesta pesquisa, referem-se a outros setores como determinantes nesse projeto de ação intersetorial, como se mostra a seguir: 
E.M. "Quando a gente está trabalhando essas agendas, a gente tende muito a forçar a barra da integração das políticas sociais e desconhece um pouco a questão da sustentabilidade econômica.

Você desenvolve o capital social, você desenvolve o capital humano, mas o desenvolvimento da capital produtivo é uma coisa mais complicada, até porque para desenvolver o capital produtivo, não dá para fazer isso restrito ao espaço de uma cidade. Você precisa de uma micro-região. Vocé precisa criar uma cadeia produtiva, agregar valor naquela cadeia, no interior da micro-região, trabalhar com conceito de endogenia micro-regional. Acho que essa separação do campo social do campo econômico nos dificulta muito. Mas, acho que com o tempo tende a ir para o diálogo."

O entrevistado acima apresenta uma série de conceitos que fundamentam a sua teoria de produção social da saúde, já apresentada em outro tópico, neste estudo. (MENDES 1996) A determinação ou a entrada da lógica econômica no setor saúde, ou melhor, nas políticas sociais tem sido objeto de várias publicações da área. (EIBENSCHUTZ 1996; GERSCHAM e VIANNA 1997; CHERCHIGLIA e DALLARI 1999)

Inicialmente, o destaque que é dado a esta questão nos depoimentos diz respeito às condições que o setor saúde apresenta, devido à sua capilaridade dentro das cidades, de realizar diagnósticos mais precisos das reais necessidades e recursos da população. Este argumento foi apresentado, anteriormente, quando se defenderam as possibilidades de parceria entre a saúde e a educação. A seguir, cita-se mais uma proposta de geração de renda ou desenvolvimento econômico, apresentada por outro entrevistado:

I.C. (...)Mesmo a questão de geração de oportunidades e geração de renda para familias e para as pessoas, é fundamental que a gente trabalhe. E por que é fundamental que a saúde também entre nesses campos? 
Quase toda a lógica do Estado brasileiro e aí eu digo: das prefeituras, governos estaduais, dos governos federais; todos eles estão montados sob uma determinada lógica de agências. Eles esperam que os problemas batam às portas deles. Eles vão trabalhar o problema a partir da demanda que se manifestou nessas agéncias. O fato é, a gente sabe, que sujeitos, comunidades, populações ou coletivos excluidos estão, também, excluidos dessas possibilidades. Eles não batem às portas porque estão excluidos, inclusive, do conhecimento de como bater.

Alguns modelos de intervenção na saúde, que têm capilaridade, que possibilitam um contato com todos os cidadãos - estejam eles doentes ou não, venham eles nas unidades ou não - permitem obter um mapa de situação muito preciso. Esses modelos permitem uma forma de atuação muito mais eficiente, até nesses campos de geração de emprego e de renda. Vou te dar alguns exemplos: os municipios às vezes descobrem, 'olha temos $13 \%$ da nossa população desempregada. Então vamos trabalhar aqui uma frente de trabalho, que vai gerar tantos empregos'. O resultado é quase sempre gerar empregos para quem já está empregado ou já está incluido. Porque quem está excluído para valer desse processo nem a isso tem acesso.(...) Identificar $13 \%$ de uma população, de um municipio desempregado é diferente de identificar a Dona Maria, que está desempregada e cuida daquela familia. E Dona Maria tem habilidades, quer dizer, tem possibilidades e tem limitações, que são peculiares à Dona Maria. Com essa nossa forma ativa de trabalhar, com essa forma dos agentes comunitários ou das equipes de Saúde da Familia, a gente pode identificar isso muito precisamente.

Então, esses programas de geração de renda podem ser muito potencializados se a saúde pautar isso na agenda. Ou seja, para eu conseguir mais saúde para uma determinada população, para um determinado conjunto de sujeitos, também, tenho que me preocupar com a garantia de condições de renda. Essa visão facilita muito o desenvolvimento de ações com essas agências. Não tenho esperança de que elas vão mudar tão rapidamente de 
conceito: passar de uma lógica passiva, de uma lógica onde as pessoas batem à porta para uma lógica ativa, delas procurarem onde o problema está. Acho que esses setores todos dos quais a gente está falando, são setores chaves para a gente trabalhar a questão do próprio setor saúde. O saneamento, o meio ambiente, os setores que trabalham a cidadania e direitos humanos, setores que trabalham com geração de oportunidades de trabalho e renda.

A preocupação ai não é de quanto determinada economia de um municipio ou de uma região possa crescer ou não crescer. Isso ai é importante, mas, a questão fundamental nossa é: como qualquer dessas coisas, vão fazer com que as pessoas tenham oportunidades de ter trabalho, de ter ingresso e de ter renda."

A renda tem sido incluida como pré-requisito da saúde em todas as cartas. E, analisando o conjunto de atribuições ou de possibilidades de intervenção da saúde apresentado até aqui, pode-se afirmar que o diagnóstico da saúde deverá assumir, em um futuro próximo, as dimensões sócio-sanitárioambiental.

Nesse depoimento, também, se introduz um outro aspecto à questão referente aos setores que deverão implementar as ações de promoção da saúde. Até este momento, se compreendeu setores enquanto áreas de conhecimento, cujos saberes e instrumentais poderiam favorecer a concretização da prática de promoção da saúde. Deste ponto, em diante, compreende-se setor, também, enquanto esferas de poder de decisão - Estado e sociedade civil, organizada ou não. O Estado, nos seus três niveis de governo, é a primeira esfera a ser citada.

O participante deste estudo, inserido no nível federal da estrutura governamental, denunciou, no depoimento anterior, o caráter de exclusão que impera na lógica de funcionamento deste. 
A mudança apresentada neste e em outros depoimentos a seguir confirmam uma afirmação de ALMEIDA (1997): “a mudança da intervenção estatal em campo social, e sanitário, acontece 'pari passu' à implementação da reforma do próprio Estado." O entrevistado, apresenta, a seguir, que uma das instâncias regulatórias ou um importante nivel decisório da implementação da promoção da saúde, é o governo.

E.M. "(...)Acho que a ordem governativa hegemônica da cidade nossa hoje se faz pela divisão técnica do trabalho. Quando você especializa uma Secretaria de Saúde, outra de Educação, outra de Habitação, outra que é Saneamento, enfim, você recorta os passos da ação. Isso de certa forma rebate no cidadão, porque este começa a ver o Governo como pedaços.(...) Acho que essa forma como os Governos estão desenhados, essa ordem governativa recortada por fragmentos que não se comunicam, é o grande entrave ao desenvolvimento dos processos globais, integrados de Promoção da Saúde.

Acho que primeiro você tem o poder convocante dessa idéia. Essa idéia é muito forte, quer se chame agenda, quer se chame desenvolvimento sustentável, local sustentável, cidade saudável... Essas idéias têm um poder de convocatória muito forte.

Segundo, reconheço que há um movimento. Não dá mais para ficar ou lidar com as coisas de forma isoladas. Você precisa ter uma visão mais global, enfrentar os problemas de uma forma mais integrada. Isso gerará certamente um novo desenho, ainda que eu veja um equivoco tremendo: alguns estão fazendo um desenho 'a priori' da estrutura ou reforma administrativa. Isso tem dados resultados paupérrimos! Você desenha... Acaba com todas as Secretarias, cria uma Secretaria do Desenvolvimento Social. Isso tem sido um desastre na prática porque isso é um atropelamento do processo. Primeiro todo mundo tem que estar consciente do que é a proposta. É fundamental vivenciar e não ser posto numa cadeira, entendeu? (...)" 
S.F. "Todos os setores envolvidos em cada nível. O nível municipal é fundamental, porque é onde acho que a coisa se dá. Porque a elaboração da política de saúde é no nível local. Mas, todos os setores estão envolvidos, em todos os niveis de governo: estadual, federal.(...) Então, acho que é preciso criar uma instância, isso em nivel ministerial, que pense esta coisa grande, que a saúde precisa ser realmente uma prioridade de todos."

V.L. "Considerando a proposta de promoção, se realmente isso viesse a ser levado a sério, em nivel de governo, seria todo o planejamento, digamos o Ministério do Planejamento ... A rigor é um trabalho que é multi-setorial. Envolve desenvolvimento regional, envolve uma coisa ... É quase que um plano de governo(...)"

Outro entrevistado considerou que várias questões formuladas, neste estudo, têm afinidade com as que ele está propondo no seu projeto de doutoramento. Algumas delas são pertinentes, neste momento, ao debate:

L.A. "E dai eu acho que o fruto dessa discussão toda da Promoção da Saúde, e ai digamos na minha ansiedade, na minha necessidade de construir coisas práticas, eu encontro como um dos nós críticos a questão da intersetorialidade. Aí.. me despertou a idéia de fazer Doutorado fazendo uma reflexão sobre a questão da intersetorialidade. Na realidade a pergunta é a seguinte: na atual estrutura do Estado Moderno, como ele está ai colocado, nascido em todo processo da constituição da modernidade e, pegando o caso do Brasil, que coloca na Constituição o conceito abrangente de saúde, que pressupõe politicas intersetoriais, que pressupõe políticas publicas na área social, esse Estado tem condições de exercer esse papel e construir essas politicas públicas? Ai eu vou mais além, no processo de descentralização das políticas publicas, num pais Federativo como o Brasil, que o municipio assume a 
questão da saúde como gestor da saúde, o municipio atual no Brasil, no desenho, na forma como ele é estruturado, pode aplicar esse conceito abrangente de saúde? Estou tentando trabalhar isso como objeto de reflexão."

LAURELL (1997) ao analisar a política de saúde no contexto das políticas sociais inicia o debate afirmando:

"Ainda que o peso especifico dos serviços de saúde na melhoria das condições coletivas de saúde seja um tema em debate, não se pode supor que é irrelevante. $\dot{E}$, além disso, um fato incontrovertido que a sociedade contemporânea tem valorizado, como um direito importante, dispor deles já que se considera, com razão ou não, que pode significar a diferença entre a vida e a morte; entre a restrição da capacidade física ou mental e o pleno desempenho destas capacidades; entre a dignidade da pessoa e condições humilhantes."

Compreende-se aqui que o acesso aos serviços de saúde se constitui uma demanda social, portanto faz parte do conjunto de necessidades percebidas por parte da população. Mas, questiona-se em que medida a saúde é percebida, no seu aspecto mais amplo (seja enquanto decorrente das condições concretas de vida ou fruto das ações e espaços promotores da saúde), a ponto de orientar "um amplo e informado debate público" que resulte em politicas públicas saudáveis.

Inseridos num contexto que apresenta como "inevitável" a nova ordem mundial - globalização ou transnacionalização, deve se investigar quais as possibilidades da saúde vir a ser a centralidade do desenvolvimento social e econômico. 
Para LAURELL (1997), a globalização seria: "Uma reforma que subordina os objetivos sociais aos econômicos ao buscar a plena mercantilização do âmbito dos serviços-beneficios sociais e a abertura de um novo campo direto de acumulação, onde a principal disputa concerne o controle sobre os fundos sociais e, no caso da saúde, a apropriação da renda tecnológica."

Observa-se, no depoimento abaixo, que o entrevistado apresenta a opinião de que o Estado deva assumir a centralidade da regulação deste processo:

L.A. "E, ai há um tensionamento para que o Estado assuma seu papel, digamos, redistributivo, eqüitativo. Ou seja, quando nós estamos discutindo Promoção da Saúde eu tendo a raciocinar muito do ponto de vista do Estado, isso pode ser um viés da minha parte, eu atribuo um papel muito importante ao Estado, pelo fato de que raciocino sempre como administrador, como gestor. Estou reconhecendo aqui essa pressão na base da sociedade civil. Eles tensionam o Estado para que... Então eu acho que isso é uma coisa de mão dupla... Eu dou essa importância ao Estado porque o Estado tem esse papel que eu acho que a gente tem que começar, cada vez mais, exigir que ele assuma.(...)"

Considerando que o Estado já não pode mais ocupar o lugar da "providência divina" e arcar com os direitos sociais conquistados ao longo do desenvolvimento das sociedades humanas, propõe-se, então, que sejam "concedidos" alguns serviços "essenciais para os comprovadamente pobres".

O desenvolvimento desta lógica no campo da saúde é analisada por LAURELL (1997), através do estudo do documento "Investir em Saúde", elaborado pelo Banco Mundial em 1993. Segundo a referida autora, este projeto teria: 
“(...) além da concepção dos serviços médicos como 'bens privados', a ineficiência das instituições públicas justificaria introduzir as forças do mercado no setor saúde e designar os recursos públicos com base no cálculo do custo-efetividade. Cabe assinalar que esta suposta ineficiência não se demonstra empiricamente, senão que é assumida como a segunida premissa da reforma.(...)"

Esta é outra dimensão do olhar da economia na saúde. Esta lógica imprime um controle financeiro dos serviços. BERLINGUER (1996) utiliza a expressão "fundamentalismo monetarista" para se referir às diretrizes desta lógica do Banco Mundial à qual os setores sociais têm se subordinado.. A partir do lançamento deste documento, muito dos direitos de cidadania têm se transformado em mercadoria.

Perde-se a perspectiva da razão, comandada pelo Estado, poder ordenar o mundo. A crise do Estado Social, onde este já não se ocupa ou não propõe mecanismos para possibilitar formas menos ameaçadoras de vida e garantir direitos sociais, traz, na visão desta autora, bastante preocupação ao se pensar a realidade brasileira. No Brasil, onde o exercício da cidadania é privilégio de poucos e prevalece o direito outorgado, fica mais difícil pensar como o controle público vai orientar a definição de prioridades ou obedecer tão somente às leis do mercado.

Assume-se que debate não pode restringir-se, apenas, à discussão do público versus privado, como se exemplifica no depoimento abaixo:

V.P. "(..)Até a década passada nós trabalhávamos, exclusivamente, no setor público e havia uma oposição formal e forte entre prestação de serviço do setor público e prestação do privado. Toda a prevenção e toda educação no setor 
público e o setor privado só querendo ganhar dinheiro, tentando se desenvolver para este lado. Hoje em dia o setor público é totalmente diverso do que era no início da década. O sistema público já foi muito melhor do que é hoje. As dificuldades do SUS hoje são tremendas para conseguir se manter, se impor dentro do país. Hoje em dia vocé já tem um mix quase obrigatório entre os setores, que nos obriga a trabalhar de outra maneira. Apesar de todos os defeitos do sistema da privatização, eu mesmo tenho travado batalhas imensas contra a privatização, hoje em dia, procura-se trabalhar viabilizando alternativas incluindo este setor. Por exemplo: no caso, do SESI, os trabalhadores estão ligados aos planos de saúde. Apesar de todos os defeitos dos planos de saúde, estes constituem uma alternativa da qual não se pode fugir, porque o setor público tem deficiências tão fortes que não consegue avançar. Então, você trabalha hoje mesclando essas coisas públicas e privadas com todo um enfoque novo. Além disso, a questão do financiamento ganhou uma importáncia vital. (...)"

BERLINGUER (1996) contribui com esse debate sobre a reestruturação do mix público/privado, afirmando ser necessário: "o equilibrio e a integração entre o público e o privado, pois a saúde é ao mesmo tempo privada e pública, individual e coletiva; a sua tutela deve ser regulamentada e garantida, não necessariamente gerenciada pelo Estado em todos os casos e em todas as formas."

CARVALHO (1996), ao refletir as implicações "das prescrições contencionistas do Banco Mundial", na saúde pública brasileira. com base em diversos autores, considera que:

"Resultam dai politicas sanitárias minimalistas, empobrecidas em sua racionalidade técnica e amesquinhadas em seu compromisso social. A abordagem interdisciplinar é dispensada de sua missão de desvendar o 
complexo sanitário, e reduzida ao subalterno papel de justificar ações intersetoriais limitadas, 'deslegitimando' a demanda espontânea por assistência e introduzindo cestas sanitárias básicas, como estratégia quase exclusiva de combate à pobreza.(...)"

Fazendo o elo com as proposições da promoção da saúde, observa-se que este conceito propõe enfrentar os determinantes sociais da saúde através da implementação de políticas e atividades que possibilitem uma vida mais saudável a todos segmentos da sociedade. Mas, causa preocupação o grande papel que os documentos que instrumentalizam este conceito atribuem às ONGs, fato que coincide com o documento do Banco Mundial anteriormente analisado. Entre as implicações da adoção desta visão, pode-se citar a vinculação dessas aos interesses das instituições que as financiam, financiamento este que solicita determinados tipos de trabalho que nem sempre caminham em direção à diminuição da exclusão na sociedade brasileira.

Percebe-se, também, que estes documentos não remetem a esta questão vinculando-a à discussão do papel do Estado na sociedade contemporânea ou estudando que tipo de Estado se faz necessário. Já, analisando o conjunto dos depoimentos, observa-se que muito dos entrevistados atribuem grande relevância à regulação deste processo pelo Estado.

Questiona-se o quão conveniente é, dentro da lógica de redução dos gastos públicos, atribuir aos indivíduos e a alguns segmentos sociais a responsabilidade por sua saúde, sem considerar quais as condições concretas de vida que estes individuos têm para fazerem escolhas ou buscarem os meios para usufruí-las. 
Dentro destas circunstâncias, fez-se necessário buscar nas propostas da promoção da saúde, como se pensava estas questões ou mesmo se estas são incorporadas nas discussões. Dois entrevistados citaram as ONGs como segmentos de decisão a serem envolvidos na implementação das ações. Mas, registra-se a seguir que, segundo a opinião dos entrevistados, estas têm um nivel de importância reduzido, se comparadas às expectativas anunciadas nas cartas.

A.V. "(...)Então, por outro lado, acho que se deve incorporar, neste ... digamos, nestas parcerias pela Promoção de Saúde, o terceiro setor. O terceiro setor, através das ONGs, deve ser incorporado no processo, que não fiquem fora, senão que façam parte da aliança. Eles têm uma grande possibilidade de trabalho a fazer. Diferente de nós, que estamos mais institucionalizados, vamos assim dizer... Que façam o trabalho dentro das possibilidades de trabalhar face a face com a população"

L.A. “(...)Eu acho que hoje as ONGs, as Organizações Não Governamentais, começam também... Eu acho que, na parte de construção desses consensos, as ONGs como um todo têm cumprido um papel importante. Daí, também, digamos, o movimento organizado.

O problema ai é: quem será o interlocutor dos não organizados? Eu acho que, como um todo, toda sociedade passa a ter um papel importante nisso. E aí tem uma coisa, que eu não sei ainda qual vai ser o impacto disso no futuro bem próximo: essa questão da informação. Nós estamos entrando na era da informação, quer dizer, o que está sendo acumulado no campo da informação, ou seja, nessa horizontalização... Eu vejo a Internet como um importante espaço de democratização. Eu ainda vejo assim: acho que tem um espaço ai futuro, a ser construido nessa questão, que eu, às vezes, chamo inteligência coletiva. Ou seja, é possivel que a gente possa, nesse processo, construir 
grandes redes. Não rede do ponto de vista da Internet em si, mas redes sociais onde a Internet passa a ter um papel importante."

Ao ler os primeiros documentos (Carta de Ottawa e Declaração de Adelaide), tem-se a impressão de que a racionalidade e propostas delas decorrentes se dāo numa relação de exterioridade ao Estado, ao contexto e às pessoas que delas se beneficiarão.

Para COHN (1997): "se a busca da modernidade não exclui, ao contrário, pressupõe a presença ativa do Estado, de um Estado democrático que incorpore os cidadãos, ela pressupõe também uma política cientifica e tecnológica na área da saúde que se assente simultaneamente no pilar da regulação e no pilar da emancipação, pilares fundamentais do projeto sociocultural da modernidade"."

O pilar da emancipação foi o aspecto mais citado pelos entrevistados, nesta questão. $O$ consenso entre os participantes se deu em cima da necessária "democratização do Estado e da sua relação com a sociedade, isto é, com seus cidadãos." (COHN 1997) Apontando, então, para uma necessária parceria do Estado com a sociedade civil.

Finaliza-se essa discussão com os depoimentos que sinalizam vários caminhos para se buscar a desejada participação popular e controle público do agir em saúde

V.P. "(...)Agora, as outras coisas dependem muito do desenvolvimento econômico. E, dentro disso, falando de setores, há um setor que tem uma

\footnotetext{
-Segundo COHN (1997), a partir de SANTOS (1996b), o pilar da regulação è constituido pelo principio do Estado, do mercado e da comunidade; o pilar da emancipação é constituído por três lógicas de racionalidade: a estético-expressiva, a moral prática da ética e do direito, e a cognitivo instrumental da ciência e da técnica."
} 
importância enorme que é o setor político, que permita que as pessoas vivam em condições mais iguais, e isso você só faz através da política. Uma boa política é fundamental para o sistema social e no sentido também da população. Há uma desmoralização dos políticos pela população na nossa sociedade contemporánea. Quer dizer, quando se fala de política não é a política dos políticos, mas sim da população mesmo, tornar a população nıais independente, mais autônoma. Para isso você precisa de pessoas com problemas básicos resolvidos, porque quem não tem onde morar, não tem como se proteger. Os estudos sociais que se fazem, indicam uma participação política, associativa, absolutamente fraquissima. As pessoas são preocupadas em sobreviver e gastam toda sua energia para isso, e também sua alegria. Então, a organização política da população é mais importante que a própria organização dos políticos."

A.V. "Acho que não pode se dar o desenvolvimento da Promoção da Saúde sem a participação e o envolvimento das lideranças políticas. Têm que existir lideranças políticas comprometidas, com força, com capacidade para conduzir o processo. Estamos falando de um país com muita diversidade, portanto, esta liderança política tem que ter capacidade política e capacidade de negociação com os diferentes interesses. Então, acho que ai, o Ministério da Saúde, as lideranças políticas que existem no mundo da saúde, os projetos, CONASS e CONASEMS etc, têm um papel a cumprir. Logo, os atores sociais, as universidades, as igrejas, os professores, os sindicatos, todos têm que, também, têm que se mobilizar para procurar o seu próprio bem-estar e melhorar a sua saúde, pois não podem aceitar estar sem a saúde.(...)"

L.A. "(...)No Brasil, cada vez mais, a questão ética passa a ser uma exigência moral da sociedade. Tem tido um aumento de transparência na sociedade brasileira. E, ai, eu acho que o impeachment do Collor passa a ser para a gente um divisor de água desse processo todo. Eu quero terminar a entrevista 
dizendo: talvez, uma das maiores obras da Promoção da Saúde, nesse país, tenha sido o impeachment do Collor, quer dizer, se você leva nessa perspectiva... O impeachment do Collor e a Promoção da Saúde é um bom artigo a ser escrito por você."

I.C. "Bom, acho que no caso em questão, do nosso, do contexto brasileiro essa questão da inclusão social e de sujeitos que estão absolutamente excluídos de todo o processo social às vezes é um item chave. É um item que é número um. Então, isso para a gente é um objetivo que deveria ser trabalhado e construido; não só construído pela saúde, mas pelo conjunto da sociedade. Então, essa questão é chave para a gente e o conjunto máximo que a gente pudesse colocar de programas, projetos, de interações nesse sentido é desejável. É um ponto que a gente precisa trabalhar. Outros aspectos que são crucias são o de como fazer isso, da forma de se fazer inclusão social. Da forma de se fazer com o "empoderamento" social, com participação social, com participação popular. Então, precisamos aprofundar um pouco mais a nossa democracia no sentido de que as pessoas possam efetivamente participar e se tornarem sujeitos elas mesmas das mudanças necessárias. Outro aspecto da promoção, que é alargar a participação social, ampliar esta participação no sentido de que as pessoas, cada vez mais, se tornem sujeitos de seus processos de adoecer, de morrer $e$ de estar bem na vida também. Esse é outro aspecto que a gente precisaria trabalhar. (...)"

M.A. "(...) A questão da promoção da saúde implicaria desenvolver uma certa cultura da segurança, cultura da paz, cultura da convivência, cultura da cooperação. Estamos vivendo em tempos bicudos, não é Dais? Em que cooperação, solidariedade, amizade, esses valores... Promoção da saúde tem a ver com solidariedade, com cooperação, com não competição. Estamos vivendo tempos complicados, que não favorecem. 
Agora, eu acho que, tem a ver com o campo da familia: o homem e a mulher, quer dizer, marido e mulher são responsáveis pela promoção da saúde no lar. Eles têm que estar preocupados com: como é que nós vamos de alguma forma potencializar as condições dessa casa para frente? O Diretor da escola tem que ter um componente de promover a saúde das pessoas que vivem ali. $O$ Prefeito tem que trabalhar com essa lógica da Promoção. E, aí, para eu promover saúde é atuar como cigano e não como bombeiro. Quer dizer, nós somos o tempo inteiro bombeiros, a gente apaga fogo. Promover saúde de alguma forma é o trabalho de cigano: é ler mão, bola de cristal, é trabalhar para o amanhã. Isso é complicado porque existe uma demanda às vezes concreta e às vezes você é ao mesmo tempo bombeiro e cigano. Quem te coordena é a sua própria consciência. Acaba você indo agir como... Como existem demandas urgentes, você de alguma forma relega a segundo plano a ação da promoção. (...)"

V.L. "(...) É quase que um plano de governo, por isso que eu acho que é utópico. Eu acho que, eu acredito mais, como eu disse a você antes, neste trabalho feito nos niveis mais próximos da população: trabalhos feitos com a comunidade, feito com as escolas, feito com a sociedade. Eu acho que, por exemplo, uma grande estratégia pode ser a adesão dos meios de comunicação de massa e comunicação social, no sentido de divulgação; sensibilização da sociedade. Eu vejo muito por ai, sabe? Eu acho que as outras estratégias devem coexistir, e elas vão ser, sobretudo, mais efetivas, na medida, em que haja uma pressão da sociedade por esta..."

P.C. Acho que tem um papel muito claro o setor popular. As agendas do movimento social na área da saúde, todos que estabelecem interface com a área de saúde devem assumir cada vez mais estes conteúdos da área da Promoção da Saúde, como determinantes das condições de saúde e vida deles. Volto a dizer que o setor acadêmico tem que fazer mudanças 
importantes e na área governamental, tem que haver mudança de atitudes e também governamentais. (...) É evidente que a sociedade brasileira tem de se desenvolver no sentido de promover coisas como noção de bem estar, que aí vai desde a reciclagem do lixo, de não se jogar o papelzinho pela janela do onibus, até o financiamento das ações de saúde. Eu acho que isto é desenvolvimento das ações da saúde, para ficar no plano concreto das coisas.

Então, acho que isso é uma mudança social intensa e não há como não fazer, que a Promoção da Saúde, tem este peso, para as pessoas. Às vezes ela assusta porque ela necessariamente compreende uma mudança da sociedade. Este é o grande desafio. Você pode ter uma grande intervenção urbana, num determinado local da cidade, quase que a revelia das pessoas que vão ser atingidas por ela, benéfica ou maleficamente. Quer dizer, já é uma mudança, no sentido positivo ou mesmo negativo, na área de promover saúde e doença e diz respeito aos hábitos das pessoas coletivamente consideradas. Năo é fácil assumir e desenvolver esta postura.(...) Já na área de Promoção da Saúde não tem jeito. O que vocé vai fazer? Vai distribuir uma pillula de saúde para as pessoas misturada no guaraná ou na cerveja, que é o que se bebe mais aqui no país? Não vai, não tem jeito. Isto assusta um pouco quando se fala em estratégias." 


\section{CONCLUSÕES}

A maioria dos entrevistados fez sua formação acadêmica na área de saúde (11 dos 12 entrevistados), sendo que oito cursaram a Faculdade de Medicina. É importante ressaltar que esses cursos, em geral, não favorecem a atuação de seus egressos em trabalhos intersetoriais.

A participação no Movimento Estudantil e em estágios extra-muros foi tida, por seis dos entrevistados, como um fator relevante que despertou 0 interesse pela participação em atividades não clínicas.

A trajetória de vida pessoal é fator determinante na ocupação de cargos, desempenho de tarefas e adoção de idéias inovadoras. Evidenciou-se, neste estudo, a grande influência de grupos primários, de suas relações pessoais e das instituiçōes, nas quais trabalhavam. Tudo isso, conjuntamente, contribuiu para que os entrevistados se interessassem pelo conceito de promoção da saúde.

Para dois dos entrevistados, o interesse pela saúde pública surgiu, evidentemente, como conseqüencia dos cargos ocupados. Verificou-se que as pessoas relacionadas à área de promoção da saúde não tiveram nenhum treinamento prévio que os familiarizasse com esta temática. Os entrevistados assumiram cargos que thes permitiram implementar ou por em prática seus ideários; ao mesmo tempo, esses ideários foram se consolidando durante o exercicio dos cargos. É fundamental reconhecer que esse percurso aconteceu em via de mão dupla, embora, se considere pertinente distinguir que poder de 
decisão é diferente de poder técnico. Até certo ponto, o conhecimento técnico pode ser construido na prática, mas isso pressupõe toda uma série de iniciativas, com acertos e erros, que poderiam ser evitadas se houvesse uma formação prévia, direcionada para as novas atribuições que se requerem.

O país mais citado, como ponto de referência de intercâmbio de experiências e qualificação na área, foi o Canadá, de onde se originaram os primeiros documentos citados, como bases da Promoção da Saúde (Informe Lalonde e Conferência de Ottawa).

A OPAS desempenha um papel fundamental na difusão da promoção da saúde, no Brasil. Isso ocorre de várias formas: financiando projetos, patrocinando eventos, prestando assessoria técnica através de seus consultores, sistematizando e disponibilizando publicações da área.

Para os entrevistados, a discussão da Promoção da Saúde, até o momento, está mais concentrada na Universidade do que nos serviços públicos. Foram relatadas experiências e estudos desenvolvidos em três centros formadores de profissionais de saúde pública: Faculdade de Saúde Pública/USP, Escola Nacional de Saúde Pública/FIOCRUZ e Escola de Saúde de Minas Gerais.

O movimento sanitário, a Reforma Sanitária e o processo de implementação do Sistema Único de Saúde (SUS) configuraram um cenário político-ideológico e estrutural que favorece a implementação de atividades ligadas à promoção da saúde no Brasil. A repercussão dessa nova concepção deu-se somente a partir do final da década de 90 , segundo o relato de duas entrevistadas. Isso ocorreu porque, anteriormente, os interesses das autoridades e lideranças da saúde pública brasileira estavam direcionados à operacionalização do SUS. 
A proposta de institucionalização da Promoção da Saúde no Brasil é um fato que emergiu na década de 90 , no entanto, os entrevistados ainda divergem quanto à eficiência do ritmo, conteúdo de estratégias e fóruns a serem utilizados, para a difusão e implantação dessa nova prática.

Observando o conjunto dos relatos de experiências dos entrevistadus, pôde-se evidenciar que as publicações e eventos sobre conceitos teóricos e operacionalização na prática da Promoção da Saúde, no Brasil, ocorreram na segunda metade da década de 90. Ao divulgar as propostas, concretizava-se, na prática, o movimento de promoção da saúde na realidade brasileira.

O movimento de cidades / municipios saudáveis foi reconhecido pelos participantes como a principal estratégia de difusão e operacionalização do conceito de promoção da saúde. Considerou-se que essa estratégia é pertinente pois dá grande visibilidade às propostas inerentes a esse conceito, possibilitando uma maior compreensão das técnicas recomendadas.

No que se refere a ambientes promotores de saúde, os mais valorizados foram o ambiente de trabalho (indústria saudável) e os hospitais, diferindo da literatura internacional e documentos técnicos da OPAS que abordam, também, a importância da atuação do sistema escolar nesse processo.

Na visão dos entrevistados, a discussão da promoção da saúde se fundamenta em valores humanitários, enquanto nas empresas ocorre, às vezes, em função de objetivos utilitaristas. Para eles, isso pode levar a uma maior dificuldade na definição de conteúdos e na determinação de objetivos comuns e, consequentemente, formação das parcerias recomendadas nos documentos internacionais. 
Os entrevistados consideram que as estratégias propostas pelo conceito de promoção da saúde devem se adequar às realidades geográfica, política, cultural, social e estrutural. Para tanto, precisam ser amplamente discutidas com o intuito de caracterizar melhor as possibilidades de sua operacionalização nos diferentes espaços setoriais das Regiões do Brasil.

As Conferências Internacionais têm se constituido em espaços de grande importância, não só pelos encontros, discussões geradas e compromissos firmados, mas também por terem fundamentado as bases conceituais do movimento de Promoção da Saúde.

Segundo dados presentes na literatura, em documentos e nas falas dos entrevistados, o conceito da Promoção da Saúde não é algo tão recente; já se faz presente na Saúde Pública desde muito antes da Conferência de Ottawa. Também se evidenciou que o conceito de Promoção da Saúde não se configura de forma univoca para todos os profissionais da saúde.

Observou-se que nos documentos, a partir da Carta de Ottawa, há um cuidado em "homogeneizar" o conceito de promoção da saúde, mesmo considerando que em cada um destes são introduzidos termos, que, na maioria das vezes, não são qualificados e que agregam novas dimensões ao conceito em construção.

Evidenciou-se neste estudo que os documentos que constituem a base conceitual do movimento de promoção da saúde são, predominantemente, cartas ou pactos de intenções, oriundos de Conferências Internacionais. Alguns entrevistados reproduzem os propósitos destes documentos acriticamente. Outros se preocupam em investigar as possibilidades deste conceito à luz das particularidades das diferentes realidades brasileiras. 
Entre os termos e conceitos ${ }^{*}$ mais freqüentemente associados à Promoção da Saúde, os que mais se destacaram foram os seguintes:

- nova forma de atuar na prática sanitária

- produção social da saúde

- conceito positivo de saúde e não apenas ênfase na prevenção da doença

- educação em saúde

- meio ambiente

- qualidade de vida

- $\quad$ estilo de vida

- "empowerment" individual e comunitário

- participação comunitária

- participação ou controle social

- intersetorialidade

- politica pública

- "advocacy" ou defesa da saúde

- "accountability" ou responsabilidade social

- promoção social

- equidade

- capital social

- parceria

- rede.

Alguns destes termos e conceitos não encontram tradução mediata no português, gerando novas terminologias. Denuncia, mais uma vez, o forte

\footnotetext{
"Termos, ao contrário de "noçăo", "conceito" e "categoria" são "simples palavras revestidas de significados; porém, emergindo do vocabulário ordinário, oriundos do senso comum, guardam uma coerencia interna ao emissor, revelam elementos do seu universo simbólico individual, mas nåo permitem evidenciar nenhuma teoria nem os elementos constituintes de um processo de conhecimento." (ESCOREL 1999)
} 
"componente internacionalista" (BUSS 1998) das propostas da promoção da saúde. Por exemplo: no Brasil, "empowerment" ora é traduzido por fortalecimento - do português; ora por "empoderamento" - do espanhol.

$\mathrm{Na}$ opinião da maioria dos entrevistados, o movimento de promoção da saúde não é reconhecido, ainda, no Brasil, como um movimento social. Os participantes deste estudo são predominantemente do setor saúde e não concordaram inteiramente com objetivos propostos, nem com as estratégias de atuação. Portanto, não configuram um movimento social, uma vez que entre os participantes predominaram as controvérsias quanto a concepção e os sentidos atribuidos ao movimento.

Todos os participantes desse movimento de promoção da saúde relatam que fundamentam suas ações em uma nova visão de saúde. Essa "nova" concepção ou mentalidade considera que saúde vai além do conceito desta enquanto resultado das condições concretas de vida, ou, tão somente, em termos da classe social, do gênero, da origem étnica, da ocupação ou do acesso aos serviços. A saúde é por eles concebida como um recurso subjetivo e objetivo, que indivíduos e comunidades contam ou recorrem frente às dificuldades, em situaçōes adversas ou nos desafios da vida. Constatou-se, ainda, que a saúde ora é sinônimo de qualidade de vida; ora é considerada uma das dimensões desta, devendo orientar ou constituir uma das diretrizes das políticas públicas.

Nem todos concordam com a visão de que o setor saúde deva ou tenha condições de assumir a liderança dessa discussão no conjunto da sociedade brasileira. Os participantes, que questionaram esse papel atribuído ao setor saúde, consideraram que, quando prevalece a lógica econômica, torna-se mais difícil orientar as políticas públicas a partir da lógica da qualidade de vida. Questionou-se, ainda, até que ponto a saúde é percebida, no seu aspecto mais 
amplo (resultado das condições concretas de vida), para orientar um debate público que resulte em políticas públicas saudáveis.

Os setores mais citados, como responsáveis pela implementação das ações de promoção da saúde, foram aqueles mais diretamente relacionados à área social: saúde, educação, meio ambiente elou saneamento, assistêricia social e/ou geração de renda.

Observou-se, no desenvolvimento desta pesquisa, que a proposta de ações intersetoriais tem sido feita mediante articulação de agendas, estruturação de projetos que constituam eixos de integração e desenvolvimento de experiências de conjugação de recursos dos diferentes setores. Essa prática tem, por consequência, introduzido novos termos na saúde pública, oriundos de outras áreas de conhecimento. A título de exemplo pode-se citar: sustentabilidade das açōes, recursos sustentáveis, Agenda 21 da saúde.

Diferentemente dos documentos internacionais, os entrevistados não atribuem grande importância às Organizações Não Governamentais (ONGs) na implementação das açōes de promoção da saúde, no Brasil. Para eles, a regulação desse processo deve ser atribuição do Estado, com participação, cada vez maior, da população.

As dificuldades existentes para a continuidade ou sustentabilidade das propostas, frente às mudanças de gestão (prefeitos, secretários etc.), podem ser atribuidas ao fato de que essas propostas são adotadas por um grupo de dirigentes, sem atingir, ainda, o ideário da população. Além da vulnerabilidade politica, nos momentos de transição administrativa, foram identificados outros fatores, tais como: falta de motivação dos profissionais decorrente de perdas de posições hierárquicas ou de transferências; fragilidade das propostas diante da diversidade de atores $e$ interesses envolvidos e dificuldades para o 
estabelecimento de mecanismos de sustentação nos niveis regional e nacional. Todos os entrevistados enfatizaram a necessidade da construção de espaços coletivos, nos serviços dos diferentes setores, objetivando o envolvimento e a real participação das pessoas nas tomadas de decisão. Confirmando evidências do estudo de MENDES (2000).

Favorecer a participação efetiva de individuos, grupos e comunidades é uma das atribuições que os documentos mais delegam aos profissionais da promoção da saúde. Esse processo de ação social tem sido denominado de "empowerment" ou fortalecimento, nos depoimentos e documentos analisados. Ao ser considerado em duas dimensões, individual e comunitária, resgata a importância de que a mudança é feita com e não para as pessoas. 


\section{CONSIDERAÇÕES FINAIS}

Atendendo às recomendações dos entrevistados, sugere-se que outros estudos sejam realizados com vistas a buscar subsídios para a avaliação da aplicabilidade do conceito e estratégias da promoção da saúde, nas diversas regiões brasileiras. Há uma expectativa, ou melhor, atribui-se às Universidades a realização de pesquisas de avaliação das experiências de promoção da saúde, em curso, no Brasil. Espera-se que, com isso, sejam identificados instrumentos e indicadores de avaliação de políticas públicas intersetoriais.

Faz-se necessário a realização de fóruns, seminários, grupos de trabalho etc., que favoreçam o maior aprofundamento das leituras e discussōes conceituais na área de promoção da saúde, pois muitos dos formadores de opinião e dos inseridos na rede de formulação de politicas restringiram o seu universo de leitura somente às cartas e declarações das Conferências Internacionais.

O instrumento utilizado para o desenvolvimento desta pesquisa mostrouse adequado aos objetivos propostos, tendo sido avaliado de maneira positiva pelos participantes. Essa avaliação foi feita, por eles, ao responderem a última questão. Pode-se, pois, recomendar a utilização de metodologia qualitativa para o levantamento de dados de estudos da mesma natureza.

Para que a saúde pública possa enfrentar adequadamente o desafio de responder a questōes da realidade contemporânea, muitas transformações e inovações são requeridas. O exercício da interdisciplinaridade e da 
multissetorialidade, ressaltadas pelos entrevistados, deve ser priorizado no planejamento e desenvolvimento das ações de saúde.

A limitação de recursos e frequente crise financeira das diferentes instituições têm impulsionado a busca de parcerias entre os diferentes setores. O setor saúde deve investir na discussão de alternativas e parâmetros para o estabelecimento das anunciadas e "desejadas" parcerias: privado-público; universidade-serviços-lideranças e grupos religiosos; ONGs-governos etc.

A distinção entre os termos Promoção da Saúde e Educação em Saúde não é, de modo algum, uma discussão abstrata ou de mero interesse acadêmico, como considerado por alguns. Trata-se de definir os tipos de estratégias, as ações e as instituições responsáveis, considerando que a promoção da saúde envolve, de forma mais ampla, aspectos políticos, legislativos, tributários. Recomenda-se que essas duas áreas de conhecimento técnico-científico considerem a atual relação de oposição mútua, onde a promoção da saúde cresce em detrimento ao da educação em saúde, e invista no desenvolvimento de uma relação de complementariedade desses dois campos de saber.

A discussão teórica e prática da promoção da saúde deve buscar a integração com outros movimentos em curso na sociedade brasileira, tais como os movimentos ecológico, étnico e de gênero, visando a fortalecer as ações dos que pleiteiam a melhoria da qualidade de vida e a diminuição das iniqüidades. Mas, para isso, requer a explicitação do que é inaceitável ou constitui "bandeira de luta" do movimento de promoção da saúde. Isso significa que não basta apenas o discurso da promoção da saúde enquanto estratégia de inclusão social de indivíduos e coletividades. Os conceitos devem ser interpretados em termos dos conflitos de interesses que ocorrem em todas as instâncias do viver cotidiano e na prática da saúde. 


\section{REFERÊNCIAS}

Adorno RCF. Qualidade de vida e formas de vida ameaçadas: a saúde e o cenário contemporâneo. São Paulo; 1997 [Tese de Livre Docência - Faculdade de Saúde Pública da USP].

Allison KR, Rootman I. Scientific rigor and community participation in health promotiom research: are they compatible? Health Promot int 1996; 11: 333-40.

Almeida CM. In: Gerschman S, Vianna ML, Organizadores A miragem da pós-modernidade. Democracia e politicas sociais no contexto da globalização. Rio de Janeiro: FIOCRUZ; 1997.

Almeida CM. Os técnicos de saúde e 0 movimento transformador: o "movimento sanitário". In: Almeida CM. Os atalhos da mudança na saúde: serviços em nivel local, 9 estudos de caso. OPAS; 1989.

Alvarez AMS. A resiliéncia e o morar na rua: um estudo com moradores de rua - crianças $\theta$ adultos - na cidade de São Paulo. São Paulo; 1999. [Dissertação de Mestrado - Faculdade de Saúde Pública da USP].

Becker MH. The tyranny of health promotion. Public Health Rev. 1986; 14: 15-23.

Bérida F. Tempo presente e presença da história. In: Ferreira MM, Amado J. Usos e abusos da história oral, organizadores. $2^{\mathrm{a} e d .}$ Rio de Janeiro: Ed. Fundação Getúlio Vargas; 1998.

Berlinguer G. 15 anos errando pela América Latina. In: Eibenschutz $C$, organizador. Política de saúde: o público e o privado. Rio de Janeiro: FIOCRUZ; 1996. 
Bicudo Pereira IMT et al. Promoção da saúde e educação em saúde: uma parceria saudável. Mundo Saúde 2000; 24 : 39-44.

Bobbio N. Os intelectuais e o poder. São Paulo: Ed. UNESP; 1997.

Bunton R, Macdonald G. Health promotion: disciplines and diversity. London: Routledge Publications; 1992.

Buss PM, Ignarra RM. Promoção da saúde: um novo paradigma mundial para a saúde. In: Ministério da Saúde. Promoção da saúde: Carta de Otawa, Declaração de Adelaide, Sundsvall e Santa Fé de Bogotá. Brasilia/DF; 1996.

Buss PM. Promoção da saúde: bases teóricos-conceituais. In: Buss PM, organizador. Promoção da saúde e a saúde pública: contribuição para o debate entre as escolas de saúde pública da América Latina. Rio de Janeiro: FIOCRUZ; 1998.

Buss PM. Promoção da saúde e qualidade de vida. Ciênc Saúde Coletiva 2000; 5: 163-77.

Campos GWS. Subjetividade e administração de pessoal. In: Merhy $E$, Onocko R, organizadores. Agir em saúde: um desafio para o público. São Paulo: HUCITEC; 1997.

Candeias NMF. Memória histórica da Faculdade de Saúde Pública da Universidade de São Paulo:1918 a 1945. Rev Saúde Pública 1984;18(nºsp.): 2-60.

Candeias NMF. Evolução histórica da educação em saúde como disciplina de ensino na Faculdade de Saúde Pública da Universidade de São Paulo:1925 a 1967. Rev Saúde Pública 1988; 22: 347-65.

Candeias NMF. Conceitos de educação e de promoção em saúde: mudanças individuais e mudanças organizacionais. Rev Saúde Pública 1997; 31: 209-13.

Candeias NMF. Promoção em saúde, a nova ciência normal. São Paulo; 1998. [Apostila da disciplina Planejamento em Promoção da Saúde - Faculdade de Saúde Pública da USP].

Carvalho Al. Da saúde pública às politicas saudáveis: saúde e 
cidadania na pós-modernidade. Ciênc Saúde Coletiva 1996;1: 104-21.

Carvalho MAR, Lima NV. O argumento histórico nas análises de saúde coletiva. In: Fleury S, organizdora. Saúde: coletiva? Questionando a onipotência do social. Rio de Janeiro: Relume-Dumará; 1992.

Carvalho MMC. Quando a história da educação é a história da disciplina e da higienização das pessoas. In: Freitas MC, organizador. História social da infância no Brasil. São Paulo: Cortez; 1997.

Castillo MML. Promocion de la salud. In: Castillo MML. et al Manual de promoción de la salud dirigido a estudiantes de enfermeria. Monterrey,México; 1993. [Facultad de EnfermeriaUniversidad Autonoma de Nuevo Leon].

Catford J. Mexico ministerial statement for the promotion of health: from ideas to action [editorial]. Health Promot Int 2000; 15: $275-6$.

Cerqueira MT. Promoción de la salud y educación para la salud: desafios e perspectivas. In: Arroyo HV, Cerqueira MT. La promoción de la salud y educación para la salud en América Latina: un análisis sectorial. San Juan: Editorial de la Universidad de Puerto Rico/OPAS; 1997.

Chaves M M. Odontologia social. 2a. ed. Rio de Janeiro: Ed. Labor do Brasil; 1977.

Cherchiglia ML, Dallari SG. A reforma do Estado e o setor público de saúde: governança e eficiência. RAP 1999; 33(5): 6584.

Cohn A. A saúde na Previdência Social e na Seguridade Social: antigos estigmas e novos desafios. In: Cohn A, Elias PE. Saúde no Brasil: politicas e organização de serviços. São Paulo: Cortez; 1996.

Cohn A Notas sobre o Estado, políticas pública e saúde. In: Gerschman S, Vianna ML, organizadores. A miragem da pósmodernidade. Democracia e políticas sociais no contexto da globalização. Rio de Janeiro: FIOCRUZ; 1997. 
Comissão Européia: Saúde e Assentamentos Humanos na América Latina, Situação da saúde urbana na América Latina. London: South Bank University; 1999.

[CONASEMS] Conselho Nacional dos Secretários Municipais de Saúde. Carta de Fortaleza. [on line] Disponivel em < URL:http://uww. conasems.com.br/fortal.htm [2000 out 13]

Costa NR. Transição e movimentos sociais: contribuição ao debate da Reforma Sanitária. In: Costa NR et al, organizadores. Demandas populares, politicas públicas e saúde: ciências sociais e saúde coletiva. Petrópolis: Vozes/ ABRASCO; 1989.

Cicourel A. Teoria e método em pesquisa de campo. In: Guimarães $A Z$, organizador Desvendando máscaras sociais. $2^{\mathbf{a}}$ ed. Rio de Janeiro: Francisco Alves; 1980.

Dejours C. Por um novo conceito de saúde. Rev Bras Saúde Ocupac 1986; 54(14): 7-11.

Dooris $M$. Healthy cities and local agenda 21: the UK experience - challenges for the new millenium. Health Promot Int 1999; 14 : 365-75.

Duarte LFD, Leal OF, organizadoras Doença, sofrimento, perturbação: perspectivas etnográficas. Rio de Janeiro: FIOCRUZ; 1998.

Egydio de Carvalho EMS. O espaço-território da educação em saúde. Oficina de territorialização de Vila Varela - Poá - São Paulo. São Paulo; 1998. [Dissertação de Mestrado - Faculdade de Saúde Pública da USP]

Eibenschutz C, organizadora. Política de saúde: o público e o privado. Rio de Janeiro: FIOCRUZ; 1996.

Epp J. Lograr la salud para todos: un marco para la promoción de la salud. In: OPAS. Promoción de la salud: una antología. Washington/DC; 1996. (Publicación Cientifica 557)

Escorel S. Reviravolta na saúde: origem e articulação do movimento sanitário. Rio de janeiro: Ed. FIOCRUZ; 1998

Escorel SN. Vidas ao léu: trajetórias de exclusão social. Rio de Janeiro: FIOCRUZ; 1999. 
Ferraz ST. Promoção da saúde: viagem entre dois paradigmas. RAP 1998; 32(2): 49-60.

Ferraz ST. Cidades saudáveis: uma urbanidade para 2000. Brasilia:Paralelo 15; 1999.

Ferreira JR, Buss PM. Atenção primária e promoção da saúde. In: Ministério da Saúde. Projeto Promoção da Saúde. Promoção da saúde: Declaração de Alma-Ata, Carta de Ottawa, Declaração de Adelaide, Declaração de Sundsvall, Declaração de Santafé de Bogotá, Declaração de Jacarta, Rede de Megapaíses, Declaração do México. Brasilia/DF; 2001.

Ferreira MAS. A prática pedagógica dos educadores em saúde pública da zona leste da Prefeitura Municipal de São Paulo. São Paulo; 1991. [Dissertação de Mestrado - PUC].

Finkelman J. A saúde é um bom investimento. Rev Promoção Saúde 1999;(2): 5-6.

FIOCRUZ. Cidades Saudáveis Tema. RADIS: 2000; 19

Freire P. In: Wanderley LE Educar para transformar: educação popular, Igreja Católica e politica no Movimento de Educação de Base. Petrópolis: Vozes; 1984.

Gentile M. Promoção da saúde. Rev. Promoção da Saúde. 1999; 1: 9-11

Gentile M. Promoção da saúde e município saudável. São Paulo: Vivere; 2001.

Gerschman S. A democracia inconclusa: um estudo da reforma sanitária brasileira. Rio de Janeiro: Ed. FIOCRUZ; 1995.

Gerschman S, Vianna ML, organizadores. A miragem da pósmodernidade. Democracia e políticas sociais no contexto da globalização. Rio de Janeiro: FIOCRUZ; 1997.

Goldbaum M. Qualidade de vida e saúde: além das condições de vida e saúde. Ciênc Saúde Coletiva 2000; 5: 19-20. 
Gonçalves $A M$ et al Proposta de um plano de ações de promoção da saúde a ser desenvolvido pela FNS. Brasilia/DF: Ministério da Saúde/COMED; 1997.

Hancock T. Health promotion in Canada: a case study. Health Promot Int 1998; 13: 7-26.

Heywood A. Politics. London: MacMillan Press; 1997.

lyda M. Cem anos de saúde pública: a cidadania negada. São Paulo: Ed. UNESP; 1994.

Jacobi PR. Movimentos sociais e Estado: efeitos políticoinstitucionais da ação coletiva. In: Costa NR et al, organizadores.

Demandas populares, políticas públicas e saúde: movimentos sociais e cidadania. Petrópolis: Vozes/ ABRASCO; 1989.

Joutar PH. História oral: balanço da metodologia e da produção nos últimos 25 anos. In: Ferreira MM, Amado J, orgnizadores. Usos e abusos da história oral. $2^{\mathrm{a} e d . ~ R i o ~ d e ~ J a n e i r o: ~ E d . ~}$ Fundação Getúlio Vargas; 1998.

Junqueira LAP. Novas formas de gestão na saúde: descentralização e intersetorialidade. Rev Saúde Soci 1997; $6(2): 31-46$.

Junqueira LAP. Descentralização e intersetorialidade: a construção de um modelo de gestão municipal. RAP 1998; 32(2): 11-22.

Junqueira RGP. A intersetorialidade do ponto de vista da educação ambiental: um estudo de caso. RAP 1998; 32(2): 7991.

Kawachi I et al. Social capital, income inequality and mortality. Am J Public Health 1997; 87: 1491-8.

Kelleher $\mathrm{C}$. Education and training in health promotion: theory and method. Health Promot Int. 1996; 11: 47-53.

Kickbusch I. Promoción de la salud: una perspectiva mundial. In: OPAS.Promoción de la salud: una antologia. Washington/ DC; 1996. (Publicación Científica 557) 
L'Abatte S. Comunicação e educação: uma prática de saúde. In: Merhy $E$, Onocko $R$, organizadores. Agir em saúde: um desafio para o público. São Paulo: HUCITEC; 1997.

Labonté R. Death of program, birth of metaphor: the development of health promotion in Canadá. In: Pederson A, O' Neill M, Rootman I. Health promotion in Canada: provincial, national \& international perspectives. Toronto; W.B. Saunders Canada; 1994. P. 72-88

Lalonde M. A new perspective on the health of canadians: a working document. Government of Canada; 1974.

Lalonde M. El concepto de campo de salud em uma perspectiva canadiense. In: OPAS. Promoción de la salud: uma antologia. Washington/ DC; 1996. (Publicación Científica 557)

Laurel AC. La política de salud en el contexto de las politicas sociales. $4^{\circ}$ Congresso Latinoamericano de Ciencias Sociales y Medicina, 1997; Cocoyoc-México. 23p.

Laville C, Dionne J. A construção do saber: manual de metodologia da pesquisa em ciências humanas. Porto Alegre: Artes Médicas/ Belo Horizonte: Ed. UFMG; 1999.

Lozano JEA. Prática e estilos de pesquisa na história oral contemporânea. In: Ferreira MM, Amado J, organizadores. Usos e abusos da história oral. $2^{\mathrm{a}}$ ed., Rio de Janeiro: Ed. Fundação Getúlio Vargas; 1998.

Martins J, Bicudo MAV. A pesquisa qualitativa em psicologia: fundamentos e recursos básicos. São Paulo: Editora Moraes/ EDUC - Ed. da PUC-SP; 1989

Meihy JCSB. Manual de história oral. $3^{\mathrm{a}}$ ed. São Paulo: Loyola; 2000.

Mendes EV. Uma agenda para a saúde. São Paulo: Ed. HUCITEC; 1996.

Minayo MCS, Hartz Z, Buss PM. Qualidade de vida: uma noção polissêmica Ciênc Saúde Coletiva 2000; 5: 1-15. 
Minayo, MCS. O desafio do conhecimento - pesquisa qualitativa em saúde. São Paulo: HUCITEC/Rio de Janeiro: ABRASCO; 1994a.

Minayo MCS, organizadora. Pesquisa social: teoria, método e criatividade. $3^{\mathrm{a}}$ ed. Petrópolis, RJ: Vozes; 1994b.

Minayo MCS. Morrer é Quase nada: o horrivel é não viver. In: Escorel S. Vidas ao léu: trajetórias de exclusão social. Rio de Janeiro: FIOCRUZ; 1999. p. 11-14

Ministério da Saúde. Promoção da saúde: Carta de Ottawa, Declaração de Adelaide, Sundsvall e Santa Fé de Bogotá. Brasilia/DF; 1996.

Ministério da Saúde. Projeto Promoção da Saúde. Promoção da saúde: Declaração de Alma-Ata, Carta de Ottawa, Declaração de Adelaide, Declaração de Sundsvall, Declaração de Santafé de Bogotá, declaração de Jacarta, Rede de Megapaises, Declaração do México. Brasilia/DF; 2001.

Monteiro CA, lunes RF, Torres AM A evolução do pais e de suas doenças: síntese, hipóteses e implicações. In: Monteiro CA, organizador. Velhos e novos males da saúde no Brasil: a evolução do pais e de suas doenças. São Paulo: HUCITEC/NUPENS-USP; 1995.

Naidoo J, Wills $\mathrm{J}$. Health promotion: foundations for practice. $3^{\text {nd }}$ ed. London: Baillière Tindall; 1996.

Nutbeam D. Glossário de promoción de la salud. In: OPAS.Promoción de la salud: una antologia. Washington/DC; 1996. (Publicación Científica 557)

Organização Pan-Americana da Saúde. Escritório de Representação no Brasil. A saúde no Brasil. Brasilia/DF; 1998.

Organización Mundial de la Salud / Ministerio de la Salud y Bienestar Social - Canada Carta de Ottawa para la promoción de la salud. Ottawa; 1986.

Organización Mundial de la Salud. Fomento de la salud a través de la escuela. Ginebra; 1997. (OMS - Serie de Informes Técnicos 870) 
Organización Panamericana de la Salud. Escuelas promotoras de salud: modelo y guía para la acción basado en la experiencia latinoamericana y caribeña. . Washington (DC);"sd"

Organización Panamericana de la Salud. Escuelas promotoras de la salud: entornos saludables y mejor salud para las generaciones futuras. Washington (DC); 1998 (OPAS Comunicación para la Salud 13)

Organización Panamericana de la Salud. Sobre escuelas promotoras de salud. [on line] Disponivel em < URL: http://165.158.1.110/spanish/hpp/hs about.htm [2001 jun 13]

Ornellas CP. Educação em saúde: prática sanitária ou instrumento de açăo ideológica? Rio de Janeiro; 1981. [Dissertação de Mestrado - Escola Nacional de Saúde Pública]

Oshiro JH. Educação para a saúde nas instituiçōes de saúde pública. São Paulo; 1988. [Dissertação de Mestrado Faculdade de Educação/Pontifícia Universidade Católica]

Paixão M. Os Indicadores de Desenvolvimento Humano (IDH) como instrumento de mensuração de desigualdades étnicas: o caso Brasil. Rio de Janeiro. 1997 [não publicado]

Pelicioni MCF. As interrelações entre a educação, saúde e meio ambiente. Rev O Biológico 1999; 61(2): 1-4.

Pereira Lima VLG, Ribeiro Campos NZ. Perfil despcritivosituacional del sector de promoción de la salud y educación para la salud en los paises de América Latina: Brasil. In: Arroyo HV, Cerqueira MT. La promoción de la salud y educación para la salud en América Latina: un análisis sectorial. San Juan: Editorial de la Universidad de Puerto Rico/OPAS;1997.

Pereira Lima VLG et al. Health promotion, health education and social communication on health: specificities, interfaces, intersections. Promot Educ 2000;7 (4): 8-12.

Pereira $M C$ et al $A$ interdisciplinaridade no fazer pedagógico Educ Soc 1991; 39: 286-96. 
Pontes $H$. Círculos de intelectuais e experiência social. Rev Bras Ciênc Soc. 1997;12 (34):57-69.

Quivy R, Campenhoudt LV. Manual de investigação em ciências socias: trajectos. Lisboa: Gradiva; 1992.

Rawson $\mathrm{D}$. The growth of health promotion theory and its rational reconstruction: lessons from the philosophy of science. In: Bunton R, Macdonald G. Health promotion: disciplines and diversity. London: Routledge Publications; 1992.

Reigota M Ecologia, elites e intelligentsia na América Latina: um estudo de suas representações sociais. São Paulo: Annablume; 1999.

Robertson A, Minkler $M$. New health promotion movement: a critical examination. Health Educ Q 1994; 21: 295-312.

Robertson A. Shifting discourses on health in Canada: from health promotion to population health. Health Promot Int 1998; 13: $155-66$.

Rocha DG. Análise do componente educativo nos programas preventivos em saúde bucal no Brasil, 19801994. São Paulo; 1997. [Dissertação de Mestrado -Faculdade de Saúde Pública da USP].

Rodriguez Neto E. A reforma sanitária e o Sistema Único de Saúde: suas origens, suas propostas, sua implantação, suas dificuldades e suas perspectivas. In:Ministério da Saúde. Coordenação de Informação, Educação e Comunicação. Incentivo à participação popular e controle social no SUS. Brasilia/DF; 1998. (Textos técnicos para conselheiros de saúde)

Santos BS. Um discurso sobre as ciências. $8^{\mathrm{a} e d}$. Porto Portugal: Ed. Afrontamento; 1996a.

Santos BS. Pela mão de Alice: o social e o politico na pós-

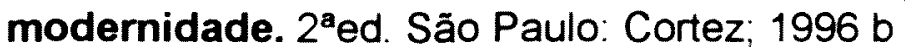

[SESI] Serviço Social da Industria SESI - Industria saudável: um processo de qualidade no trabalho para empresas brasileiras. Brasília/DF; 2000.

Silveira G. Escola promotora de saúde: quem sabe faz a 
hora! São Paulo; 2000. [Tese de Doutorado - Faculdade de Saúde Pública da USP]

Sossai JÁ. Saúde escolar no Brasil: alguns aspectos administrativos. Rev Bras Saúde esc1992; 2(2): 63-9.

Teixeira SF, organizadora. Reforma sanitária: em busca de uma teoria. $2^{a}$ ed. São Paulo: Cortez / Rio de Janeiro: ABRASCO; 1995.

Terris M. Conceptos de la promoción de la salud: dualidades de la teoria de la salud pública. In: Organizacion Panamericana de la Salud/ Organizacion Mundial de la Salud. Promoción de la salud: una antologia. Washington/DC; 1996. (Publicación Cientifica 557)

Touraine A. Sociologia e sociedade In: Foracchi MM, Martins JS. Leituras de introdução à sociologia. Rio de Janeiro: Livros Técnicos e Cientificos; 1980.

Touraine A. Os novos conflitos sociais: para evitar malentendidos. Rev Lua Nova 1989; 17: 5-18.

Touraine, A. Crítica da modernidade. Petrópolis: Vozes; 1994.

Tourtier-Bonazzi C. Arquivos: propostas metodológicas. In: Ferreira MM, Amado J, organizadores. Usos e abusos da história oral. $2^{\mathrm{a}}$ ed. Rio de Janeiro: Ed. Fundação Getúlio Vargas; 1998.

Vasconcellos MPC. Os (des)caminhos da formação sanitária e os direitos sociais: uma reflexão a partir da Escola de Saúde de Minas Gerais. São Paulo; 2000. [Tese de Doutorado - Faculdade de Saúde Pública da USP].

Viana ALD. Novos riscos, a cidade e a intersetorialidade das políticas públicas. RAP 1998; 32(2): 23-33.

Vianna SM et al Medindo as desigualdades em saúde no Brasil: uma proposta de monitoramento. Brasilia/DF: Organização Pan-Americana de Saúdel Instituto de Pesquisa Econômica Aplicada; 2001.

Vieira MPA et al. A pesquisa em história. São Paulo: Ática; 1989. 
Voldman D. Definições e usos. In: Ferreira MM, Amado J, organizadores. Usos e abusos da história oral. $2^{\text {a }}$ ed. Rio de Janeiro: Ed. Fundação Getúlio Vargas; 1998.

Westphal MF. A Declaração de Jacarta sobre Promoção da Saúde no século XXI. São Paulo: Faculdade de Saúde Pública, 1997a.

Westphal MF. Municipios saudáveis: aspectos conceituais. Rev. Saúde Soc 1997b; 6(2): 9-18

Westphal MF. Recursos educativos e métodos de avaliação em promoção em saúde. São Paulo; 1998a [ Texto do Curso de Especialização em Promoção da Saúde - Faculdade de Saúde Pública da USP]

Westphal MF. A promoção da saúde no Brasil; 1998b. [não publicado]

Xavier C. Cidade saudável, uma filosofia e uma idéia. Tema RADIS 2000; 19: 3-6.

Ziglio $E$ et al Principles, methodology and practices of investiments for health. Promot Educ 2000;7 (2): 4-15. 
14. ANEXOS 


\section{ANEXO 1 \\ ROTEIRO DE ENTREVISTA}

Gostaria de agradecer a sua contribuição para este estudo, se dispondo a conversarmos hoje.

1. Gostaria que o $\mathrm{Sr}$.(Sra) começasse me falando um pouco da sua trajetória no setor saúde: quando começa a atuar, os principais trabalhos que considera ter realizado, os fatos mais relevantes:

2. Em que contexto (momento) da vida profissional se deu sua aproximação à Promoção em Saúde?

3. Houve alguma leitura, pesquisa ou evento que contribuiu, influenciou ou despertou o seu interesse para a Promoção em Saúde?

4. Do seu ponto de vista, que idéias (valores) propiciaram (levaram) o interesse pela Promoção em Saúde, no Brasil?

5. O que entende hoje por Promoção em Saúde? Houve mudança neste conceito, de quando o conheceu até o presente momento?

6. Para você, quais são os objetivos da Promoção em Saúde?

7. Quais são as estratégias (meios) delineadas para atingir os objetivos da Promoção em Saúde?

8. Há diferenças de significados entre Educação em Saúde e Promoção em Saúde? Caso a resposta seja afirmativa, como estes se distinguem?

9. Tem trabalhado (pesquisado) com a Promoção em Saúde (capacitação/ cursos, pesquisa, assessoria de planejamento de programas)?

10. Você considera que tem havido uma difusão da Promoção em Saúde no Brasil? Na sua opinião, quais as principais estratégias que têm sido adotadas?

11. Tem havido financiamento direcionado para esta área? Quais a(s) fonte(s) financiadoras?

12. Estabelece contato ou intercambia informações com alguém da área de Promoção em Saúde no Brasil? Como as mantém e são estas mediadas por outros grupos ou instituições? 
13. Dos fóruns (encontros) nacionais e intemacionais (seminários, congressos) de ou com a temática de Promoção em Saúde realizados no Brasil quais você participou? Caso a resposta seja afirmativa: como foi informado, participou de algum e como se deu esta participação (expositor, ouvinte, coordenação de trabalhos)?

14. Quais as expectativas que você tem com a difusão da Promoção em Saúde no Brasil?

15. Na sua opinião, quais os setores sociais seriam responsáveis pelo planejamento, implantação e desenvolvimento da Promoção em Saúde?

16. Quais os principais obstáculos que você identifica para a introdução formal da Promoção em Saúde nos órgãos oficiais, no Brasil?

17. Quais os principais aspectos facilitadores para a introdução formal da Promoção em Saúde nos órgãos oficiais, no Brasil?

18. Na sua opinião, o movimento de promoção da saúde é ou pode ser considerado (identificado como) um movimento social? Por que?

19. Ao final, este é um espaço reservado para uma eventual abordagem que você julgue necessária e que não tenha sido contemplada na concepção das questões: 


\section{ANEXO 2 \\ TERMO DE CONSENTIMENTO}

Prezado entrevistado(a):

Gostaria de pedir-lhe autorização para inserir e utilizar o seu depoimento, obtido através desta entrevista, no meu estudo e tese de Doutoramento sobre "O movimento da promoção em saúde na década de 90: um estudo do seu desenvolvimento e difusão na saúde pública brasileira", tanto no seu suporte escrito como em sua forma oral.

Grata por sua participação,

Dais Gonçalves Rocha

Você autoriza?

( ) Sim

( ) Não

Assinatura:

Data da entrevista: / l

Em caso afirmativo, tem alguma observação ou consideração a fazer sobre o uso deste depoimento?

Formas de contactá-lo(la):

Endereço residencial:

CEP.

Telefone(s):Comercial

Residencial

e-mail: 


\section{ANEXO 3 \\ Lista dos Informantes}

\begin{tabular}{|c|c|}
\hline A.V. & $\begin{array}{l}\text { Angel Valonça } \\
\text { Graduado em Medicina na Bolivia } \\
\text { Mestrado em Epidemiologia } \\
\text { Ex-Ministro da Saúde da Bolívia } \\
\text { Consultor da OPAS no Brasil desde agosto de } 1996 .\end{array}$ \\
\hline E.M & $\begin{array}{l}\text { Eugénio Vilaça Mendes } \\
\text { Graduado em Odontologia pela FO/UFMG } \\
\text { Doutor em Cirurgia Buço-Maxilo Facial } \\
\text { Especializaçăo em Planejamento em Saúde pela ENSP/FIOCRUZ } \\
\text { Mestrado em Administraçăo de Empresa pela Faculdade de Ciências } \\
\text { Económicas/UFMG } \\
\text { Consultor da OPAS por } 11 \text { anos } \\
\text { Autor de vários livros, atualmente é consultor free-lancer }\end{array}$ \\
\hline I.C. & $\begin{array}{l}\text { Tvan Batista Coelho } \\
\text { Graduado em Medicina pela UFMG } \\
\text { Residéncia em Medicina Preventiva pela UFMG } \\
\text { Ex-Secretário Municipal de Saúde de Betim-MG } \\
\text { Coordenador do Projeto de Promoçåo da Saúde da Secretaria de Políticas de Saúde } \\
\text { do Ministério da Saúde }\end{array}$ \\
\hline J.Y. & $\begin{array}{l}\text { Jožo Yunes } \\
\text { Fez Medicina na FM/USP } \\
\text { Mestre em Saúde Pública - Michigan/EUA } \\
\text { Doutor em Pediatria Social pela FM/USP } \\
\text { Livre-Docéncia em Pediatria Social - FM/USP } \\
\text { Professor Titular da FSPNSP } \\
\text { Ex-Secretário da Secretaria de Politicas de Saúde do Ministério da Saúde } \\
\text { Consultor da OPAS } \\
\text { Diretor da Faculdade de Saúde Pública da USP }\end{array}$ \\
\hline L.A. & $\begin{array}{l}\text { Lutz Odorico M. de Andrade } \\
\text { Graduação em Medicina pela FMUUFCE } \\
\text { Residéncia em Medicina Preventiva } \\
\text { Mestrado em Saúde Pública pela UFCE } \\
\text { Secretário Municipal de Saúde de Sobral - CE } \\
\text { Diretor da Secretaria de Relaçóes Internacionais do CONASEMS }\end{array}$ \\
\hline M.A. & $\begin{array}{l}\text { Marco Ackermam } \\
\text { Graduado em Medicina na UFMG } \\
\text { Fez Residência em Medicina Social } \\
\text { Especialização em Administraçăo Hospitalar } \\
\text { Mestrado em Planejamento e Financiamento do Setor Saúde em Londres } \\
\text { Doutorado em Avaliaçăo de Serviços de Saúde em Londres } \\
\text { Professor Titular de Saúde Coleța da Faculdade de Medicina do ABC } \\
\text { Coordenador de Saúde da CASSI (Caixa de Assistência da Saúde dos Funcionários do } \\
\text { Banco do Brasil) }\end{array}$ \\
\hline P.C. & $\begin{array}{l}\text { Paulo Capucci } \\
\text { Graduado em Odontologia, em Ribeirâo Preto, pela FO/USP } \\
\text { Graduado em Educaçăo em Saúde na FSPN SP } \\
\text { Mestre em Administraçăo de Serviços de saúde } \\
\text { Presidente da Associaçăo Paulista de Saúde Pública }\end{array}$ \\
\hline
\end{tabular}




\begin{tabular}{|c|c|}
\hline P.B. & $\begin{array}{l}\text { Paulo Buss } \\
\text { Graduado em Medicina, em Santa Maria pela UFRS } \\
\text { Residéncia em Pediatria } \\
\text { Mestrado em Medicina Social pela UERJ } \\
\text { Primeiro Secretário Executivo da ABRASCO } \\
\text { Diretor da ENSP/FIOCRUZ } \\
\text { Presidente da ALAESP (Associaçăo Latino-Americana das Escolas de Saúde Pública) }\end{array}$ \\
\hline P.N. & $\begin{array}{l}\text { Paulo Nazareno } \\
\text { Graduado em Medicina na UFCE } \\
\text { Ex-Secretário Municipal de Saúde de Crateús-CE } \\
\text { Prefeito de Crateús-CE } \\
\text { Coordenador da Rede Brasileira de Municípios Saudáveis }\end{array}$ \\
\hline S.F. & $\begin{array}{l}\text { Sonia Terra Ferraz } \\
\text { Graduada em Medicina na Faculdade de Săo José do Rio Preto } \\
\text { Atuaçăo na Secretaria Estadual de Saúde Săo Paulo na Direçăo de Centro de Saúde, } \\
\text { Distrito e Regional } \\
\text { Ex - Consultora da OPAS } \\
\text { Mestrado em Administraçăo dos Serviços de Saúde - Universidade de } \\
\text { Montreal/Canadá } \\
\text { Assessora Técnica do CONASEMS }\end{array}$ \\
\hline V.L. & $\begin{array}{l}\text { Vera Lúcia G. Poreira Lima } \\
\text { Graduaçăo em Pedagogia } \\
\text { Livre-Docéncia na Área de Educaçăo em Saúde } \\
\text { Professora Titular Aposentada da Faculdade de Pedagogia da UFRJ } \\
\text { Representante da UIPES (Uniåo Internacional de Promoção e Educação em Saúde) na } \\
\text { Sub-Regiáo Brasil } \\
\text { Co-Autora do Capitulo referente ao Brasil no livro La promoción de la salud y la } \\
\text { educación para la salud en America Latina, publicado pela OPAS }\end{array}$ \\
\hline V.P. & $\begin{array}{l}\text { Vitor Gomes Pinto } \\
\text { Graduação em Odontologia pela UFRS } \\
\text { Especialização, Mestrado e Doutorado na FSPNSP } \\
\text { Ex-Coordenador Geral de Planejamento do Ministério da saúde } \\
\text { Ex-Coordenador da Saúde Bucal do Ministério da saúde } \\
\text { Ex-Consultor da OPAS } \\
\text { Coordenador da Unidade de Conhecimento e Tecnologia da Saúde do SESI }\end{array}$ \\
\hline
\end{tabular}

